Prepared for the U.S. Department of Energy under Contract DE-AC05-76RL01830

\title{
Secondary Waste Form Screening Test Results-Cast Stone and Alkali Alumino-Silicate Geopolymer
}
EM Pierce
W Um
KJ Cantrell
MM Valenta
JH Westsik, Jr.
RJ Serne
KE Parker

June 2010

\section{Pacific Northwest}

NATIONAL LABORATORY

Proudly Operated by Battelle Since 1965 


\title{
DISCLAIMER
}

This report was prepared as an account of work sponsored by an agency of the United States Government. Neither the United States Government nor any agency thereof, nor Battelle Memorial Institute, nor any of their employees, makes any warranty, express or implied, or assumes any legal liability or responsibility for the accuracy, completeness, or usefulness of any information, apparatus, product, or process disclosed, or represents that its use would not infringe privately owned rights. Reference herein to any specific commercial product, process, or service by trade name, trademark, manufacturer, or otherwise does not necessarily constitute or imply its endorsement, recommendation, or favoring by the United States Government or any agency thereof, or Battelle Memorial Institute. The views and opinions of authors expressed herein do not necessarily state or reflect those of the United States Government or any agency thereof.

\author{
PACIFIC NORTHWEST NATIONAL LABORATORY \\ operated by \\ BATTELLE \\ for the \\ UNITED STATES DEPARTMENT OF ENERGY \\ under Contract DE-AC05-76RL01830
}

Printed in the United States of America
Available to DOE and DOE contractors from the Office of Scientific and Technical Information,
P.O. Box 62, Oak Ridge, TN 37831-0062;
ph: (865) 576-8401
fax: $(865)$ 576-5728
email: reports@adonis.osti.gov

\begin{abstract}
Available to the public from the National Technical Information Service, U.S. Department of Commerce, 5285 Port Royal Rd., Springfield, VA 22161 ph: (800) 553-6847 fax: $(703) 605-6900$ email: orders@ntis.fedworld.gov online ordering: http://www.ntis.gov/ordering.htm
\end{abstract}

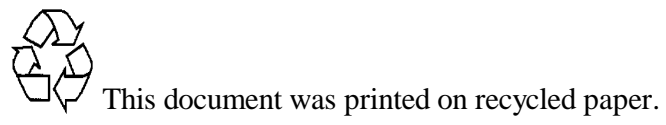




\title{
Secondary Waste Form Screening Test Results-Cast Stone and Alkali Alumino-Silicate Geopolymer
}

\author{
EM Pierce W Um \\ KJ Cantrell MM Valenta \\ JH Westsik, Jr. RJ Serne \\ KE Parker
}

June 2010

Prepared for

the U.S. Department of Energy

under Contract DE-AC05-76RL01830

Pacific Northwest National Laboratory

Richland, Washington 99352 


\section{Executive Summary}

Washington River Protection Solutions (WRPS) is responsible for the design and construction of upgrades to the Effluent Treatment Facility (ETF) at Hanford necessary to support the 2018 operation of the Hanford Tank Waste Treatment and Immobilization Plant (WTP). Upgrades to ETF will include a Solidification Treatment Unit (STU). The ETF is a Resource Conservation and Recovery Act (RCRA)permitted multi-waste treatment and storage unit that can accept dangerous, low-level, and mixed wastewaters for treatment. Addition of the STU to ETF will provide the additional capacity needed for ETF to process the increased volume of secondary wastes expected to be produced by WTP. Although the current baseline calls for solidification of the ETF evaporator concentrate in a cement-based waste form, an evaluation is being conducted to identify and characterize other candidate stabilization technologies that are mature enough and have the potential of successfully treating the WTP's secondary liquid waste stream.

Pacific Northwest National Laboratory (PNNL) is initiating a waste form testing program to support the evaluation and selection of waste forms for stabilization and solidification of the liquid secondary waste stream from the WTP. A literature survey was conducted to identify candidate waste forms. The candidate stabilization technologies selected include Cast Stone, Duralith alkali-alumino-silicate geopolymer (Geopolymer), fluidized-bed steam reformer (FBSR) granular product encapsulated in a geopolymer matrix, and a Ceramicrete phosphate bonded ceramic. These wastes forms have been shown to meet waste disposal acceptance criteria, including compressive strength and universal treatment standards for RCRA metals (as measured by the Toxicity Characteristic Leaching Procedure [TCLP]) to be acceptable for land disposal. Previous testing reported in the literature indicated there were some formulation issues that needed to be addressed for the Geopolymer and Ceramicrete waste forms, and information is needed on all four waste forms with respect to their ability to minimize the release of technetium. Technetium is a radionuclide predicted to be in the secondary liquid wastes in small quantities, and a recent risk assessment analyses for the Integrated Disposal Facility (IDF) showed technetium has the largest contribution to the estimated IDF disposal impacts to groundwater.

To support a final waste form down selection, PNNL is conducting screening tests on the candidate waste forms to provide a basis for comparison and to resolve the formulation and data needs identified in the literature review. This report documents the screening test results on the Cast Stone cementitious waste form and the Geopolymer waste form. Screening tests on the Ceramicrete phosphate bonded ceramic and the encapsulated FBSR material will be conducted and documented as those materials become available. Later, more comprehensive and longer term performance testing will be conducted, following the guidance provided by the secondary waste form selection, development, and performance evaluation roadmap (PNNL 2009a). The resulting waste form will be compliant to regulations and performance criteria and will lead to cost-effective disposal of the secondary wastes.

Specific test methods to screen candidate liquid stabilization options are needed, and they need to provide a framework to 1) rapidly assess material performance, 2) provide some indication of the dominant release mechanism for specific contaminants of concern (COC), 3) evaluate the strengths and weaknesses of a variety of materials (placing each material on a level playing field), and 4) gain regulatory acceptance by drawing on standard test methods approved by the regulatory community. To address these test needs, three out of four draft test protocols being developed for the U.S. Environmental Protection Agency (EPA) were used to screen each of the stabilization technologies. The four test 
protocols are listed below and Methods 1313, 1315, and 1316 were used to obtain the data discussed in this report.

- EPA Draft Method 1313-Leaching Test (Liquid-Solid Partitioning as a Function of Extract pH) of Constituents in Solid Materials Using a Parallel Batch Extraction Test (EPA 2009a)

- EPA Draft Method 1314-Leaching Test (Liquid-Solid Partitioning as a Function of Liquid-Solid Ratio) of Constituents in Solid Materials Using an Up-Flow Percolation Column (EPA 2009b)

- EPA Draft Method 1315-Mass Transfer Rates of Constituents in Monolith or Compacted Granular Materials Using a Semi-Dynamic Tank Leaching Test (EPA 2009c)

- EPA Draft Method 1316 - Leaching Test (Liquid-Solid Partitioning as a Function of Liquid to Solid Ratio) of Constituents in Solid Materials Using a Parallel Batch Extraction Test (EPA 2009d).

The EPA Draft Methods are a combination of static, column, and semi-dynamic leach experiments that can be used to provide more detailed mechanistic information on material performance in comparison to the current standard leach methods, such as American National Standards Institute (ANSI) 16.1 and TCLP. The EPA Draft Method 1313 is a static-leach test method where nine parallel extraction experiments are conducted in dilute acid or base with deionized (DI) water at a fixed $\mathrm{pH}$ and liquid-tosolid ratio. Draft Method 1316 uses DI water as the leachant instead of a dilute acid or base at a fixed liquid-to-solid ratio. The EPA Draft Method 1315 is a 63-day, semi-dynamic leach experiment that consists of submerging a monolithic sample (with a fixed geometry) in water at a fixed liquid-to-solid ratio for a fixed period of time. At each of the nine pre-determined leaching intervals, the sample mass is recorded, and the leachant is changed. This method is similar to ANSI/American Nuclear Society (ANS) 16.1, but the intervals are different. The leachate solutions collected from each of the test methods are analyzed to determine the 1) $\mathrm{pH}, 2$ ) electrical conductivity, 3) concentration of specific dissolved components, and 4) redox conditions. Finally, the results from the aforementioned EPA test methods are expected to provide detailed information on the amount and release behavior of key contaminants under specific conditions and to gain insight into the processes and mechanisms controlling element release. These results need to be coupled with geochemical modeling and with a select number of chemical and solid-phase characterization techniques to evaluate pre- and post-test solid phases.

For the screening tests, 4-inch by 2-inch diameter cylinders of the Cast Stone and Geopolymer were prepared from a secondary waste stream simulant spiked with technetium-99. The simulant composition was representative of the secondary liquid wastes to be treated and solidified in ETF. These wastes are composed of liquid wastes from the caustic scrubber in the low-activity waste (LAW) vitrification facility and evaporator condensates from the pretreatment plant. The caustic scrubber is downstream of the primary LAW vitrification off-gas treatment system and is expected to capture volatile iodine, RCRA metals, and technetium not removed earlier in the process. As part of the secondary off-gas treatment system, the caustic scrubber is downstream of the high-efficiency particulate air (HEPA) filters used for particulate removal; the carbon beds for mercury removal; and the selective catalytic reduction beds for oxidizing volatile organic compounds, sulfur oxides $\left(\mathrm{SO}_{\mathrm{x}}\right)$, and carbon monoxide and for nitrogen oxide $\left(\mathrm{NO}_{\mathrm{x}}\right)$ reduction. The caustic scrubber liquid effluents are returned to the pretreatment plant, where they are combined with the pretreatment evaporator condensates and sent to the Liquid Effluent Retention Facility (LERF)/ETF, becoming the source of the secondary wastes requiring treatment for volatile ${ }^{99} \mathrm{Tc}$ and ${ }^{129} \mathrm{I}$, and other RCRA metals. This secondary waste is composed of mainly sodium (2M), aluminum $(0.2 \mathrm{M})$, hydroxide $(1.2 \mathrm{M})$, nitrate $(0.69 \mathrm{M})$, and oxalate $(0.23 \mathrm{M})$. This report focuses on ${ }^{99} \mathrm{Tc}$ leachability 
because it is the most problematic and key groundwater risk driver contaminant in the secondary waste, in addition leaching data for iodide and selected RCRA metals were also measured in the screening tests and reported herein.

Both the Cast Stone and Geopolymer appear to be viable waste forms for the solidification of the secondary liquid wastes to be treated in the ETF. This conclusion is based primarily on the diffusivity calculations for the release of technetium as determined by the EPA Method 1315. The diffusivity for technetium from the Cast Stone monoliths was in the range of $1.2 \times 10^{-11}$ to $2.3 \times 10^{-13} \mathrm{~cm}^{2} / \mathrm{s}$ during the 63 days of testing. The diffusivity for technetium from the Geopolymer was in the range of $1.7 \times 10^{-10}$ to $3.8 \times 10^{-12} \mathrm{~cm}^{2} / \mathrm{s}$ through the 63 days of the test. These values compare with a target of $1 \times 10^{-9} \mathrm{~cm}^{2} / \mathrm{s}$ or less. The Geopolymer continues to show some fabrication issues with the diffusivities ranging from $1.7 \times$ $10^{-10}$ to $3.8 \times 10^{-12} \mathrm{~cm}^{2} / \mathrm{s}$ for the better-performing batch to from $1.2 \times 10^{-9}$ to $1.8 \times 10^{-11} \mathrm{~cm}^{2} / \mathrm{s}$ for the poorer-performing batch. However, through 63 days of immersion testing, the samples did not illustrate significant fracturing of the material as shown in Duralith samples from an earlier study of low temperature immobilization technologies.

In the EPA methods 1313 and 1316, the Cast Stone and Geopolymer showed similar leaching behavior. For both waste forms, the natural solution $\mathrm{pH}$ after soaking in deionized water is approximately 12. Based on the fractions leached, iodide, technetium, mercury, and arsenic are more leachable than sodium and potassium, which are also more leachable than the waste form matrix materials silicon and aluminum. These results suggest the most leachable species reside predominantly in the pore water and that sodium and potassium, while partially in the pore water, are also partially bound within the structural matrix of the waste forms. As such, relatively high fraction releases for the technetium from the crushed waste form samples would be expected because of the large surface area and exposed pores. In the intact monoliths, the releases of all constituents would be much slower because of the tortuosity factor between interconnected pores, the lower porosity, and small pore throat sizes.

The waste forms were characterized with respect to their chemical and crystalline compositions. Both materials are largely amorphous. The Cast Stone is $>88$ weight percent (wt $\%$ ) amorphous with ettringite and calcite as the only identified crystalline phases. The Geopolymer is $>70 \mathrm{wt} \%$ amorphous with quartz from the sand and fumed silica components as the identified crystalline phase. The dry materials used to form each waste form were also characterized for chemical and crystalline composition. This information is available in the report to support design and safety analyses. The dry materials contain significant quantities of the hazardous RCRA metals ( $\mathrm{As}, \mathrm{Cd}, \mathrm{Cr}, \mathrm{Cu}, \mathrm{Hg}$, and $\mathrm{Pb}$ ), and, for some contaminants of concern, they are the largest contributor to the overall final solidified waste form inventory.

The next phase of testing of the Cast Stone and Geopolymer will provide additional information about the waste form properties to support a final down selection to a waste form for the secondary wastes. The testing will focus on three areas: 1) waste form development and optimization, 2) mechanisms of radionuclide retention, and 3) regulatory and waste acceptance testing. Waste form development and optimization will focus on optimizing waste loading and evaluating the robustness of the waste form to waste variability. The evaluation of mechanism of radionuclide retention will provide some confidence that the waste performance observed in the short-term screening tests offer an indication of the long-term performance of the waste form in the disposal environment. The regulatory and waste acceptance testing will focus on obtaining waste form data to support waste disposal permitting and waste acceptance criteria for the IDF. 
Following a final waste form selection, secondary waste form testing will be directed toward testing to support detailed design of the STU for IDF; data collection to support risk assessments and long-term performance assessments; and, as appropriate, further optimization of the waste form to reduce costs and improve performance. 


\section{Acknowledgements}

The authors wish to acknowledge K. Colosi, T. May, and M. Melvin at Washington River Protection Solutions, LLC (Richland, Washington) for providing project funding and technical guidance. The authors would also like to acknowledge the technical support of Dr. Weiliang Gong from Catholic University of America in the preparation of the Duralith Alkali Geopolymer samples. The authors also would like to thank E.A. Cordova, S.R. Baum, E.T. Clayton, C. Iovin, and I.V. Kutnyakov (all from PNNL) for helping carry out various aspects of the work described in this report. We are particularly grateful to Charity Plata (PNNL), Wayne Cosby (PNNL), and Megan Spanner (PNNL) for completing the editorial review of this technical report. 



\section{Acronyms and Abbreviations}

\begin{tabular}{|c|c|}
\hline ANS & American Nuclear Society \\
\hline ANSI & American National Standards Institute \\
\hline ASTM & American Society for Testing and Materials \\
\hline BET & Brunauer-Emmett-Teller \\
\hline BFS & blast furnace slag \\
\hline CBPC & chemically bonded phosphate ceramic \\
\hline $\mathrm{CD}$ & Critical Decision \\
\hline $\mathrm{COC}$ & contaminants of concern \\
\hline C-S-H & hydrous calcium and silica-rich gel \\
\hline DI & deionized (water) \\
\hline DOE & U.S. Department of Energy \\
\hline Ecology & Washington State Department of Ecology \\
\hline EDS & energy dispersive spectrometry \\
\hline $\mathrm{Eh}$ & oxidation-reduction potential \\
\hline EM & U.S. Department of Energy Office of Environmental Management \\
\hline EPA & U.S. Environmental Protection Agency \\
\hline EQL & estimated quantitation limit \\
\hline ETF & Effluent Treatment Facility \\
\hline FBSR & fluidized-bed steam reformation \\
\hline FY & fiscal year \\
\hline HEPA & high-efficiency particulate air \\
\hline $\mathrm{HF}$ & hydrogen fluoride \\
\hline HLW & high-level waste \\
\hline IC & ion chromatography \\
\hline ICP-MS & inductively coupled plasma mass spectroscopy \\
\hline ICP-OES & inductively coupled plasma optical emission spectroscopy \\
\hline IDF & Integrated Disposal Facility \\
\hline ILAW & immobilized low-activity waste \\
\hline JCPDS & Joint Committee on Powder Diffraction Standards \\
\hline $\mathrm{KOH}$ & potassium hydroxide \\
\hline LAW & low-activity waste \\
\hline $\mathrm{LBH}$ & layered bismuth hydroxides \\
\hline $\mathrm{LDH}$ & layered double hydroxide \\
\hline LERF & Liquid Effluent Retention Facility \\
\hline LI & Leachability Index \\
\hline LLW & low-level waste \\
\hline
\end{tabular}


MDL

MKP

MS

NRC

ORP

PDFTM

$\mathrm{pH}$

PNNL

PUREX

redox

RCRA

SEM

STU

TCLP

WRPS

WTP

XRD

$\mathrm{XRF}$ minimum detection limit

$\mathrm{MgO}$ and $\mathrm{KH}_{2} \mathrm{PO}_{4}$

mass spectroscopy

U.S. Nuclear Regulatory Commission

US Department of Energy Office of River Protection

powder diffraction file

measure of the acidity of a solution, where $\mathrm{pH}$ is the negative of the logarithm of the activity of $\mathrm{H}+$ in solution

Pacific Northwest National Laboratory

plutonium uranium extraction

reduction-oxidation (process)

Resource Conservation and Recovery Act

scanning electron microscopy

Solidification Treatment Unit

Toxicity Characteristics Leaching Procedure

Washington River Protection Solutions, LLC

Hanford Tank Waste Treatment and Immobilization Plant

$\mathrm{X}$-ray diffraction

$\mathrm{X}$-ray fluorescence 


\section{Units of Measure}

$\theta$

$\AA$

${ }^{\circ} \mathrm{C}$

$\mathrm{cm}$

$\mathrm{g}$

$\mu$

$\mu \mathrm{m}$

$\mathrm{mS} / \mathrm{cm}$

$\mathrm{M}$

$\mathrm{mL}$

rpm

$\lambda$

$\mathrm{wt} \%$ angle of incidence (Bragg angle)

angstrom $\left(10^{-10} \mathrm{~m}\right.$ or $\left.10^{-1} \mu \mathrm{m}\right)$

temperature in degrees Celsius $\left[\mathrm{T}\left({ }^{\circ} \mathrm{C}\right)=\mathrm{T}(\mathrm{K})-273.15\right]$

centimeter

gram

micro (prefix, $10^{-6}$ )

micrometer

millisiemens per centimeter (electrical conductance)

molarity, $\mathrm{mol} / \mathrm{L}$

milliliter

revolutions per minute

wavelength

weight percent 



\section{Contents}

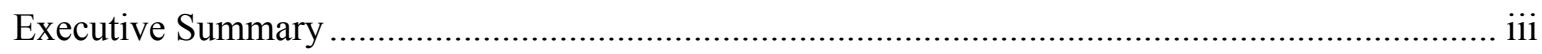

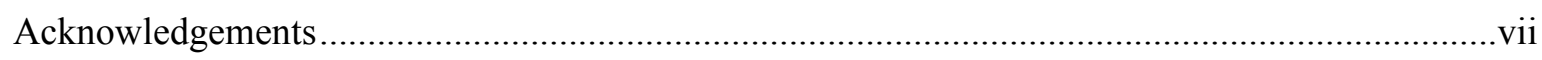

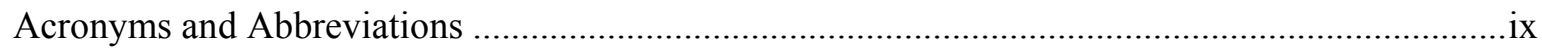

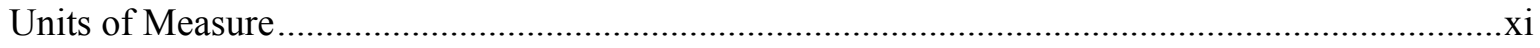

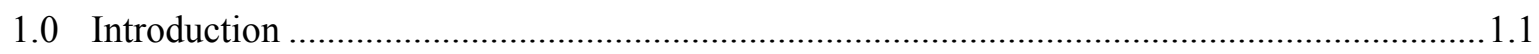

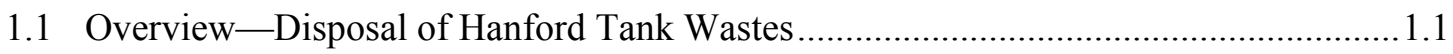

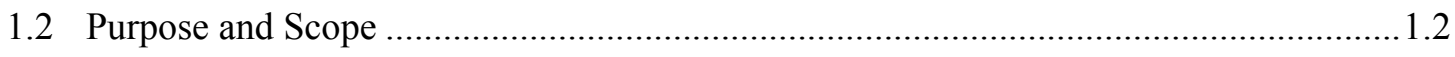

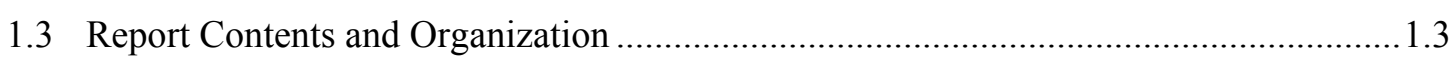

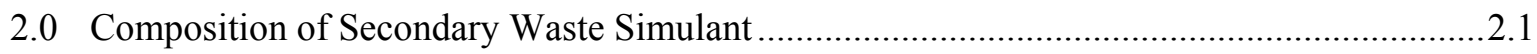

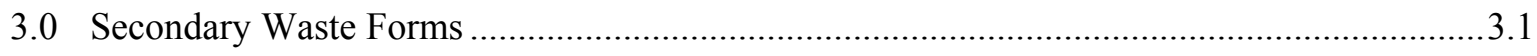

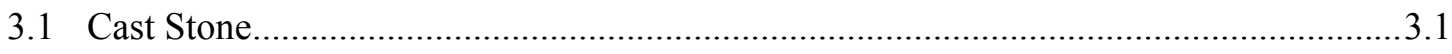

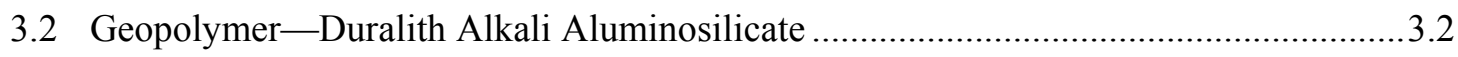

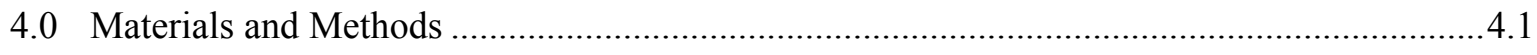

4.1 Material Preparation Techniques ....................................................................... 4.1

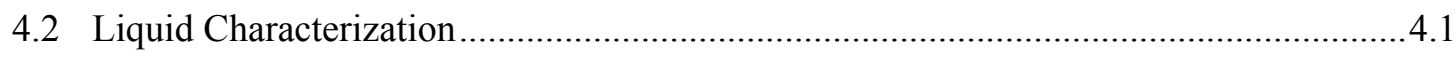

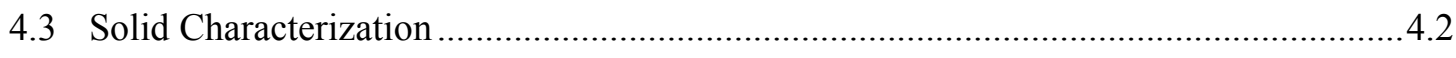

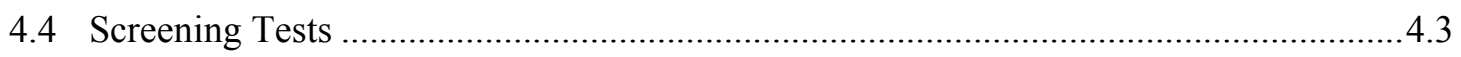

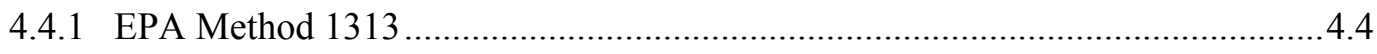

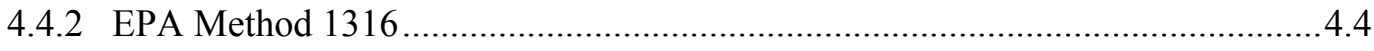

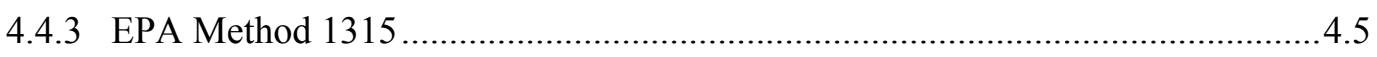

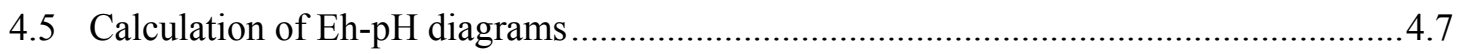

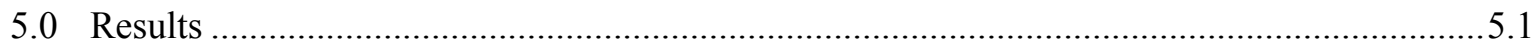

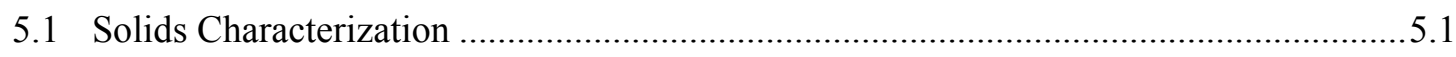

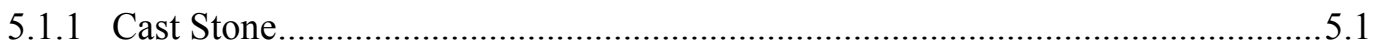

5.1.2 Geopolymer-Duralith Alkali Aluminosilicate …...........................................5.8

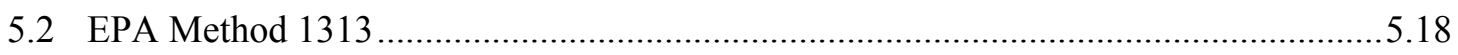

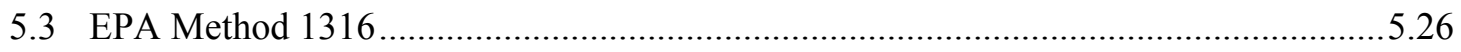

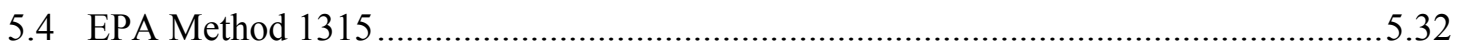

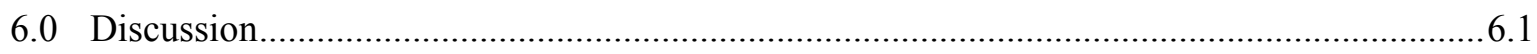

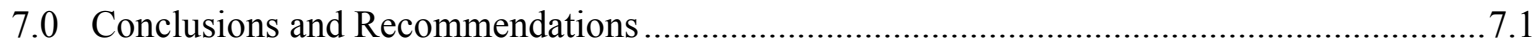

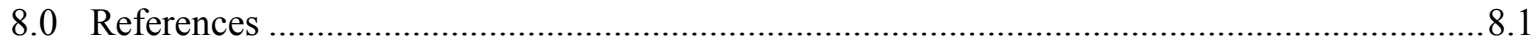




\section{Figures}

3.1 Picture of Raw Materials, Fly Ash, and Portland Cement Type II and 28-Day Cured Cast Stone Monolith......................................................................................................... $\quad 3.2$

3.2 Picture of 30-Day Cured Geopolymer Monolith.......................................................................

4.1 An Example of the Type of Static Container Used to Conduct the EPA 1313 and 1316 Test Methods.....

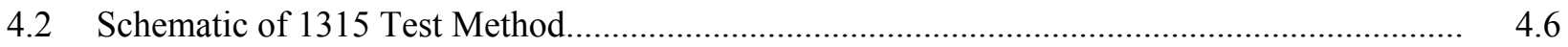

4.3 Duplicate Monoliths of Cast Stone Submerged into DI Water in the Leaching Vessels with the Lids

5.1 X-Ray Diffraction Patterns for Raw Materials-BFS, Fly Ash, and Portland Cement Type II—and 28-Day Cured Cast Stone ............................................................................... 5.3

5.2 Blast Furnace Slag SEM Image and EDS Spectra. ........................................................... 5.5

5.3 Fly Ash SEM Images and EDS Spectrum...................................................................... 5.6

5.4 Portland Cement SEM Images and EDS Spectrum …..................................................... 5.7

5.5 SEM Image of 28-Day Cured Cast Stone ....................................................................... 5.8

5.6 X-Ray Diffraction Spectra of Raw Material—Fume Silica, Meta-Kaolinite, Furnace Slag, Sand, and Ag-Zeolite — and 30-Day Cured Geopolymer batch \#1 ................................ 5.12

5.7 SEM Micrographs and EDS Spectrum of Fume Silica ......................................................... 5.13

5.8 SEM Micrographs and EDS Spectrum of Meta-Kaolinite ................................................. 5.14

5.9 SEM Micrographs and EDS Spectrum of Furnace Slag .................................................... 5.15

5.10 SEM Micrographs and EDS Spectrum of Sand …........................................................... 5.16

5.11 SEM Micrographs and EDS Spectrum of Ag-Zeolite...................................................... 5.17

5.12 SEM Micrograph of an Unreacted Sample of 30-day Cured Geopolymer Batch \#1 ................ 5.18

5.13 Titration Curves with Leaching Data for Cast Stone; Geopolymer Batch \#1; Geopolymer Batch \#2

5.14 Eh-pH Stability Diagram for Dominant Technetium Species at $25^{\circ} \mathrm{C}$ for the Leachants

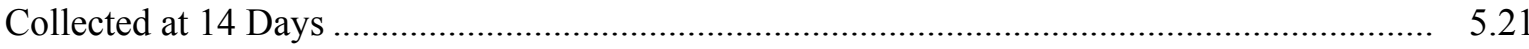

5.15 Leached Tc of Three Waste Forms in Method 1313 _............................................................... 5.22

5.16 Leached Tc of Three Waste Forms in Method 1316 ............................................................. 5.28

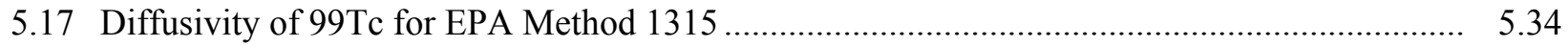

6.1 XRD Pattern of Reacted Cast Stone at $\mathrm{pH}=4.0,7.0$, and 12.0 from EPA Method 1313 and Change in Calcite 100 Percent as a Function of $\mathrm{pH}$ 


\section{Tables}

2.1 Composition of WTP Secondary Waste Simulant ........................................................... 2.2

2.2 Chemicals Used in Making WTP Secondary Waste Simulant................................................ 2.3

3.1 Material Specifications and Composition …...................................................................... 3.1

3.2 Material Specifications and Composition for Geopolymer Monoliths .................................. 3.3

5.1 Chemical Composition, in $\mu \mathrm{g} / \mathrm{g}$, of Raw Materials-Fly Ash, Blast Furnace Slag, and Portland Cement - and 28-Day Cured Cast Stone.

5.2 Chemical Composition, in $\mu \mathrm{g} / \mathrm{g}$, of a Portion of the Raw Materials - Fumed Silica, Meta-Kaolinite, Furnace Slag, Sand, and Ag-Zeolite-Used to Prepare the Geopolymer Samples

5.3 Chemical Composition, in $\mu \mathrm{g} / \mathrm{g}$, of 28-Day Cured Geopolymer Samples from Batch \#1 and Batch \#2.

5.4 The Values of pH, EC, Eh, and Alkalinity of Three Waste Forms Measured from the EPA Method 1313

5.5 The Concentrations of Major Cations in Eluate for Waste Forms from 1313 Method

5.6 The Concentrations of RCRA Metals in Eluate for Waste Forms from 1313 Method

5.7 The Concentrations of Major Anions, ${ }^{99} \mathrm{Tc}$, and ${ }^{127} \mathrm{I}$ in Eluate for Waste Forms from 1313 Method

5.8 The Values of pH, EC, Eh, and Alkalinity of Three Waste Forms Measured from the EPA Method 1316

5.9 The Concentrations of Major Cations in Eluate for Waste Forms from 1316 Method

5.10 The Concentrations of RCRA Metals in Eluate for Waste Forms from 1316 Method

5.11 The Concentrations of Major Anions, ${ }^{99} \mathrm{Tc}$, and ${ }^{127} \mathrm{I}$ in Eluate for Waste Forms from 1316 Method

$5.12 \mathrm{pH}, \mathrm{EC}$, Eh and Alkalinity Results for EPA Method 1315.

5.13 The Concentrations of Major Cations in Eluate for Waste Forms from EPA Method 1315

5.14 The Concentrations of RCRA Metals in Eluate for Waste Forms from EPA Method 1315

5.15 The Concentrations of Major Anions, ${ }^{99} \mathrm{Tc}$, and ${ }^{127} \mathrm{I}$ in Eluate for Waste Forms from EPA Method 1315.

6.1 The Diffusivity and Leachability Index for $\mathrm{As}, \mathrm{Cd}, \mathrm{Cr}$, and $\mathrm{Pb}$ in Eluate for Waste Forms from EPA Method 1315

6.2 The Diffusivity and Leachability Index for $\mathrm{Ag}, \mathrm{Hg}$, and $\mathrm{Cu}$ in Eluate for Waste Forms from EPA Method 1315

6.3 The Diffusivity and Leachability Index for $\mathrm{Ag}, \mathrm{Hg}$, and $\mathrm{Cu}$ in Eluate for Waste Forms from EPA Method 1315 . 


\subsection{Introduction}

The federal facilities located on the Hanford Site in southeastern Washington State have been used extensively by the U.S. government to produce nuclear materials for the U.S. strategic defense arsenal. Currently, the Hanford Site is under the stewardship of the U.S. Department of Energy (DOE) Office of Environmental Management (EM). A large inventory of radioactive and mixed waste, resulting from the production of nuclear materials, has accumulated, mainly in 177 underground single- and double-shell tanks located in the central plateau of the Hanford Site (Mann 2002). The DOE EM Office of River Protection (ORP) is proceeding with plans to permanently dispose of the liquid and solid wastes contained in the tanks. Pacific Northwest National Laboratory (PNNL) was contracted to initiate a waste form testing program to support evaluation of the long-term durability of a waste form for the solidification of secondary wastes generated from the treatment and immobilization of Hanford radioactive tank wastes.

\subsection{Overview-Disposal of Hanford Tank Wastes}

Under the ORP Hanford tank waste disposal plans, liquid and solid wastes first will be retrieved from the tanks and transferred to preprocessing facilities at the Hanford Tank Waste Treatment and Immobilization Plant (WTP). In the pretreatment facility, the sludges (insoluble material) will be washed and the liquids processed to generate a high-level waste (HLW) fraction and a low-activity waste (LAW) fraction. The HLW fraction will contain the bulk of the radionuclides, particularly the actinides. The low-activity fraction will contain predominately inactive sodium and aluminum from LAW processing and technetium-99 $\left({ }^{99} \mathrm{Tc}\right)$ as the major radionuclide. Both waste streams will be converted to glass at vitrification facilities in the WTP. The LAW fraction is destined to be disposed of on the Hanford Site in the Integrated Disposal Facility (IDF) (Ecology et al. 1989), and the HLW fraction will be transferred to a proposed HLW repository (previously Yucca Mountain). In addition to the vitrified HLW and immobilized LAW (ILAW) glass, the waste processing steps being implemented at the WTP will generate secondary wastes that must be processed, stabilized, and disposed of in the IDF.

The secondary wastes that will be generated from processing tank wastes include routine solid wastes and liquid process effluents. Because ${ }^{99} \mathrm{Tc}$ and iodine-129 $\left({ }^{129} \mathrm{I}\right)$ will volatilize when exposed to the high processing temperatures used to produce glass, the solid and liquid secondary waste streams are expected to contain a portion of the total ${ }^{99} \mathrm{Tc}$ and ${ }^{129} \mathrm{I}$ inventory. Solid wastes from the waste treatment facilities may include failed equipment, decontamination wastes, high-efficiency particulate air (HEPA) filters, carbon absorption beds, silver mordenite iodine sorbent beds, and spent ion-exchange resin. Liquid wastes may include process condensates and scrubber and/or off-gas treatment liquids from the thermal waste treatment processes. After packaging, the solid secondary wastes will be sent to the IDF for disposal. The liquid-effluent secondary wastes will be sent to the Effluent Treatment Facility (ETF) for further treatment and disposal, either as treated liquid effluents under the ETF State Wastewater Discharge Permit or as solidified liquid effluents under the Dangerous Waste Permit for disposal at the IDF. This report focuses on the testing of potential low-temperature solidification agents for stabilizing the secondary waste liquid effluent that will be sent to ETF.

The ETF is a Resource Conservation and Recovery Act (RCRA)-permitted multi-waste treatment and storage unit that can accept dangerous, low-level, and mixed wastewaters for treatment. The ETF receives liquid effluents from cleanup projects on the Hanford Site, which are disposed of after being 
treated. Currently, ETF supports the 242-A Evaporator, Mixed Waste Burial Trench, and Environmental Restoration Disposal Facility leachates; groundwater treatment projects; and other decontamination and decommissioning projects. The liquid effluents are treated to remove toxic metals, radionuclides, and ammonia and to destroy organic compounds. Plans are to increase the capacity of the ETF to process the increased volume of secondary wastes when the WTP begins waste treatment and immobilization operations (Koci 2005). A Solidification Treatment Unit (STU) will be added to the ETF to provide the necessary additional capacity. The current baseline calls for solidification of the ETF evaporator concentrate in a cement-based waste form. The cement will be cast into 4-ft by 4 -ft by 4 - $\mathrm{ft}$ cubes for curing, storage, and disposal.

Washington River Protection Solutions, LLC (WRPS) has been chartered to move forward with the design and construction of the STU for the ETF. To receive secondary liquid wastes from the WTP, the STU needs to be operational by 2018. There will be a formal decision on the waste form for the secondary liquid wastes, including agreement with the Washington State Department of Ecology (Ecology), by 2012. Screening tests of candidate waste forms are being conducted to support the DOE Critical Decision process and the selection of the waste form for the secondary wastes.

Significant uncertainties are associated with the processing of these secondary wastes, and, in 2008, the DOE Office of Engineering and Technology (OE\&T) sponsored a meeting to develop a roadmap to outline the steps necessary to design the secondary waste forms. At the highest level, the secondary waste roadmap (PNNL 2009a) includes elements addressing regulatory and performance requirements, waste composition, preliminary waste form screening, waste form development, process design and support, and validation. The regulatory and performance requirements activity will provide the secondary waste form performance requirements. The waste-composition activity will provide workable ranges of secondary waste compositions and formulations for simulants and surrogates. Preliminary waste form screening will identify candidate waste forms for immobilizing the secondary wastes. The waste form development activity will mature the waste forms, leading to a selected waste form(s) with a defensible understanding of the long-term release rate and input into the Critical Decision process for a secondary waste treatment process and/or facility. The process and design support activity will provide a reliable process flowsheet and input to support a robust facility design. The validation effort will confirm that the selected waste form meets regulatory requirements. The final outcome of the implementation of the secondary waste roadmap is the compliant, effective, timely, and cost-effective disposal of the secondary wastes.

\subsection{Purpose and Scope}

The purpose of PNNL's work documented in this report is to conduct an initial evaluation (i.e., screening) of candidate stabilization technologies that have the potential to successfully treat liquid effluent produced by the WTP as part of the secondary waste stream. This document represents an interim report describing the selection and composition of the secondary waste simulant and the results collected to date from screening tests conducted on candidate stabilization technologies. Four candidate stabilization technologies were identified as viable and selected for further evaluation as part of a Phase I secondary waste form testing program. The candidate stabilization technologies selected include Cast Stone, Duralith alkali-alumino-silicate geopolymer (Geopolymer), fluidized-bed steam reformer (FBSR) encapsulated in a geopolymer matrix, and a Ceramicrete phosphate bonded ceramic. This report documents results of screening tests on the Cast Stone and Geopolymer waste forms. Screening tests on 
the encapsulated FBSR product and the Ceramicrete will be conducted as samples become available, and the results will be documented in future reports.

\subsection{Report Contents and Organization}

The ensuing sections of this report document the materials and steps used to prepare the simulant (Section 2.0), as well as the batches of Cast Stone (Section 3.1) and Geopolymer (Section 3.2).

Section 4.0 describes the methods used to characterize and evaluate the processes that affect contaminant release from Cast Stone and Geopolymer. The results collected to date from these methods are presented, discussed, and summarized in Sections 5.0, 6.0, and 7.0. The Appendix A through F contains the details of the Cast Stone raw material, Geopolymer procedure received from CUA, additional x-ray diffraction patterns and scanning electron microscopy for Cast Stone and Geopolymer, and a series of Eh-pH diagrams for specific contaminants of concern. 


\subsection{Composition of Secondary Waste Simulant}

The secondary liquid wastes to be treated and solidified in ETF are composed of liquid wastes from the caustic scrubber in the LAW vitrification facility and evaporator condensates from the pretreatment plant. The caustic scrubber is downstream of the primary LAW vitrification off-gas treatment system and is expected to capture volatile RCRA metals, iodine and technetium not removed earlier in the process. As part of the secondary off-gas treatment system, the caustic scrubber is downstream of the HEPA filters used for particulate removal; the carbon beds for mercury removal; and the selective catalytic reduction beds for oxidizing volatile organic compounds, sulfur oxides $\left(\mathrm{SO}_{\mathrm{x}}\right)$, and carbon monoxide and for nitrogen oxide $\left(\mathrm{NO}_{\mathrm{x}}\right)$ reduction. The caustic scrubber liquid effluents are returned to the pretreatment plant, where they are combined with the pretreatment evaporator condensates and sent to the Liquid Effluent Retention Facility (LERF)/ETF, becoming the source of the secondary wastes requiring treatment.

The primary LAW vitrification off-gas treatment system is composed of the submerged bed scrubber (SBS) and the wet electrostatic precipitator (WESP). In the baseline WTP process, the liquid effluents from these two off-gas treatment components are recycled back to the pretreatment plant to be concentrated and included in the treated LAW concentrate sent to the LAW vitrification facility for conversion to glass. Initially, the SBS and WESP liquid effluents are not included in the secondary waste stream sent to LERF/ETF. However, the ETF upgrades are being designed for the flexibility to process occasional SBS/WESP blowdown, which could alleviate the potential problem of constituent concentration buildup in the recycle loop.

The ETF uses an evaporator to reduce waste volume. This step in the secondary waste treatment process is expected to increase the concentration of key contaminants of concern (COC) in the waste stream. The target concentration for the final secondary waste stream that will be solidified using the chosen technology is $2 \mathrm{M}$ sodium $(\mathrm{Na})$ balanced with major anions such as hydroxide (1.2M) and nitrate $(0.69 \mathrm{M})$. More details on the composition of WTP secondary waste simulant are provided in Table 2.1.

The liquid secondary waste simulant composition was developed using flow sheet model simulations of the WTP process. Table 2.1 column 3 [from Melvin, (2009)]shows the specific composition that was used to fabricate the Phase I candidate solid waste forms used in laboratory tests, along with the composition used previously in Russell et al. (2006) for an earlier evaluation of candidate low temperature waste forms for solidification of liquid secondary wastes. The target composition is adapted from an analysis of a G2 flowsheet model run (MRQ 09-0019 Scenario 5.0.22a, Node RLD-TK00006B_ETF-1). The model node for the baseline case (caustic scrubber) is for the process condensate collection tank (RLD-06B) that holds the liquid wastes to be sent to LERF/ETF. In totalizer mode, the model provides the composition of the liquid residing in the RLD-06B tank on a monthly basis. To provide a simulant concentration, the predicted monthly concentrations were first normalized to $2 \mathrm{M} \mathrm{Na}$, then averaged over 241 months. After averaging, it was necessary to increase the amount of sodium to provide a charge balance based on the averaged estimates of $\mathrm{NO}_{3}{ }^{-}, \mathrm{CO}_{3}{ }^{2-}, \mathrm{PO}_{4}{ }^{3-}$, and $\mathrm{SO}_{4}{ }^{2-}$. Because of the need to increase the analytical sensitivity for RCRA metals (namely silver, cadmium, and lead) in the screening tests, the concentrations of these COC were spiked at 100 times their maximum expected concentration as indicated in Table 2.1. The concentration of chromium was not increased because the simulant concentration for this COC is sufficient to achieve the analytical sensitivity required to obtain quantitative information from the Phase I screening tests. The technetium concentration in the simulant 
was set at its maximum expected concentration. The simulant was prepared by mixing $18 \Omega \mathrm{M}-\mathrm{cm}$ deionized (DI) water with reagent-grade chemicals. The mass of chemicals per liter of solution is provided in Table 2.2.

Table 2.1. Composition of WTP Secondary Waste Simulant

\begin{tabular}{|c|c|c|}
\hline Element & $\begin{array}{c}\text { Target (Moles/L) } \\
\text { Russell et al. (2006) }\end{array}$ & $\begin{array}{c}\text { Target (Moles/L) } \\
\text { Adapted from Melvin (2009) }\end{array}$ \\
\hline $\mathrm{Na}$ & 2.0 & 2.0 \\
\hline $\mathrm{Al}$ & 0.011 & 0.23 \\
\hline $\mathrm{Cr}$ & $2.8 \mathrm{E}-04(100 \mathrm{x})$ & 3.7E-04 (1x) \\
\hline $\mathrm{Ag}$ & $2.2 \mathrm{E}-04(100 \mathrm{x})$ & $2.5 \mathrm{E}-04(100 \mathrm{x})$ \\
\hline $\mathrm{Cd}$ & $1.4 \mathrm{E}-05(100 \mathrm{x})$ & 5.E-05 (100x) \\
\hline $\operatorname{Re}^{(a)}$ & $6.00 \mathrm{E}-07$ & $N I^{(b)}$ \\
\hline${ }^{99} \mathrm{Tc}$ & NI & $7.7 \mathrm{E}-06^{(\mathrm{c})}$ \\
\hline I & $2.90 \mathrm{E}-06$ & $2.90 \mathrm{E}-06$ \\
\hline $\mathrm{Hg}$ & $2.4 \mathrm{E}-06$ & 3.3E-05 (1x) \\
\hline $\mathrm{Pb}$ & $1.5 \mathrm{E}-04(100 \mathrm{x})$ & 7.9E-04 (100x) \\
\hline $\mathrm{CO}_{3}^{-}$ & 0.96 & $1.5 \mathrm{E}-06$ \\
\hline $\mathrm{NO}_{3}^{-}$ & 0.018 & 0.69 \\
\hline $\mathrm{OH}^{-}$ & 0.094 & 1.2 \\
\hline $\mathrm{PO}_{4}{ }^{3-}$ & NI & $1.7 \mathrm{E}-02$ \\
\hline $\mathrm{SO}_{4}{ }^{2-}$ & NI & $9.7 \mathrm{E}-03$ \\
\hline TOC (as oxalate) & 0.18 & 0.23 \\
\hline $\begin{array}{l}\text { (a) } \mathrm{Re} \text { - Used as a chem } \\
\text { (b) } \mathrm{NI}-\text { Not included } \\
\text { (c) }{ }^{99} \mathrm{Tc}=1.3 \mathrm{E}-05 \mathrm{Ci} / \mathrm{L}\end{array}$ & l analogue for ${ }^{99} \mathrm{Tc}$ & \\
\hline
\end{tabular}


Table 2.2. Chemicals Used in Making WTP Secondary Waste Simulant

\begin{tabular}{cc}
\hline Chemical Formula & Grams/Liter \\
\hline $\mathrm{NaOH}$ & $4.80 \mathrm{E}+01$ \\
$\mathrm{NaAlO}_{2}$ & $1.77 \mathrm{E}+01$ \\
$\mathrm{Cr}\left(\mathrm{NO}_{3}\right)_{3}$ & $1.48 \mathrm{E}-01$ \\
$\mathrm{AgNO}_{3}$ & $4.25 \mathrm{E}-02$ \\
$\mathrm{Cd}\left(\mathrm{NO}_{3}\right)_{2}$ & $1.18 \mathrm{E}-02$ \\
${ }^{99} \mathrm{Tc}$ & $8.45 \mathrm{E}-04$ \\
$\mathrm{NaI}$ & $4.35 \mathrm{E}-04$ \\
$\mathrm{Hg}\left(\mathrm{NO}_{3}\right)_{2}$ & $1.07 \mathrm{E}-02$ \\
$\mathrm{~Pb}\left(\mathrm{NO}_{3}\right)_{2}$ & $2.62 \mathrm{E}-01$ \\
$\mathrm{Na}_{2} \mathrm{CO}_{3}^{-}$ & $1.59 \mathrm{E}-04$ \\
$\mathrm{NaNO}_{3}$ & $3.90 \mathrm{E}+01$ \\
$\mathrm{Na}_{3} \mathrm{PO}_{4}$ & $2.79 \mathrm{E}+00$ \\
$\mathrm{Na}_{2} \mathrm{SO}_{4}$ & $3.13 \mathrm{E}+00$ \\
$\mathrm{Na}_{2} \mathrm{C}_{2} \mathrm{O}_{4}$ & $3.08 \mathrm{E}+01$ \\
\hline
\end{tabular}




\subsection{Secondary Waste Forms}

At this time, a total of 19 monolithic samples had been prepared using the secondary waste composition as previously discussed. The target simulant loading was 8 weight percent (wt $\%)$ on a dry basis for each monolith. Four Cast Stone samples and 15 Geopolymer samples were prepared. The 15 Geopolymer samples were prepared in two separate batches - Geopolymer batch \#1 (10 of the 15) and Geopolymer batch \#2 (five of the 15). All monoliths were cast in 2-inch diameter by 4-inch length cylindrical molds. The steps used to prepare each set of monoliths are discussed as follows.

\subsection{Cast Stone}

The composition for the Cast Stone is listed in Table 3.1 and includes sulfate-resistant Portland Type I/II cement; a pozzolanic material (Class F fly ash); and blast furnace slag (BFS), Grade 100. The Portland cement and BFS were obtained from LaFarge North America, Inc. (Herndon, Virginia) (see Appendix A). The fly ash was obtained from Lonestar (Seattle, Washington).

The Cast Stone monoliths were prepared based upon a procedure from Cooke et al. (2008) by adding the components in the following order: cement, fly ash, BFS, technetium-spiked stimulant, and DI water. The dry materials were blended for five minutes using a planetary mixer set at low speed. After the dry mixture was homogenous, the technetium-spiked simulant and water were added to the blended dry mixture. The materials were mixed for five minutes to ensure homogeneity. Polycarbonate sleeves were used as molds for casting monoliths. The molds were partially filled in the vertical position and vibrated until a significant decrease in the release of air bubbles was observed. Then, the molds were filled again with additional wet slurry and vibrated until no air bubbles were observed. This process was repeated until the molds were completely filled. The molds were stored in a $100 \%$ relative humidity chamber for five days, at which time the Cast Stone monoliths were removed from the molds. The monoliths were subsequently stored in the humidity chamber for an additional 23 days for a total curing time of 28 days. Photos of the raw materials and a cast monolith are shown in Figure 3.1.

Table 3.1. Material Specifications and Composition

\begin{tabular}{|c|c|c|}
\hline Material & Specifications & $\begin{array}{l}\text { Amount Used (g) } \\
\text { Per Monolith }\end{array}$ \\
\hline Simulant & & 96.7 \\
\hline Cement & Portland cement, Type I/II & 76.82 \\
\hline Fly Ash & Class F & 431.95 \\
\hline Blast Furnace Slag & Type 100 & 451.21 \\
\hline Deionized Water & & 276.7 \\
\hline
\end{tabular}



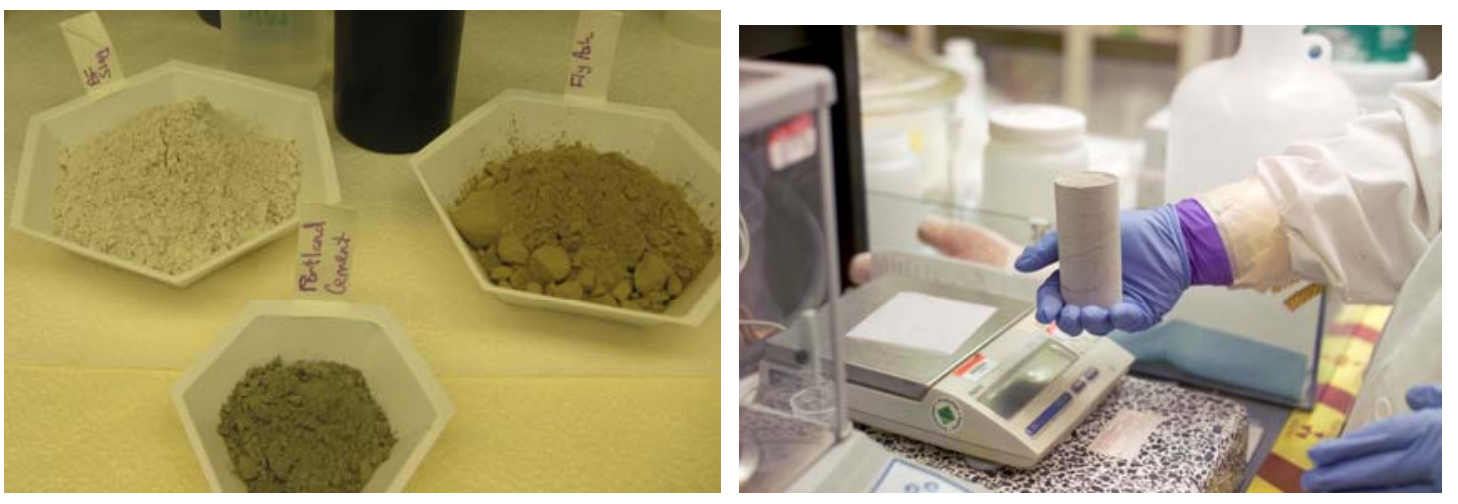

Figure 3.1. Picture of Raw Materials (Left) (BFS [Top Left], Fly Ash [Top Right], and Portland Cement Type II [Bottom]) and 28-Day Cured Cast Stone Monolith (Right)

\subsection{Geopolymer-Duralith Alkali Aluminosilicate}

The Geopolymer monoliths were prepared from a recipe provided by Dr. Weiliang Gong from Catholic University of America (see Appendix B). The composition is listed in Table 3.2. First, an activator solution was prepared by adding the simulant solution and tin fluoride to a $4 \mathrm{~L}$ Teflon beaker and stirring for one hour. Tin ( $\mathrm{Sn}[\mathrm{II}]$ ) fluoride is used as a reducing agent for redox sensitive elements such as technetium. This step also calls for the addition of silver nitrate to aid in the immobilization of iodide. However, due to the low concentration of iodide present in the simulant, Dr. Gong determined that adding silver nitrate was unnecessary, so it was not added. Next, potassium hydroxide (KOH) was added to the Teflon beaker and allowed to mix until the $\mathrm{KOH}$ was fully dissolved. In addition to $\mathrm{KOH}$, sodium hydroxide also was slowly added to the mixture until it completely dissolved. Finally, the fumed silica was slowly added. The mixture was heated to approximately $50^{\circ} \mathrm{C}$ and stirred until the fumed silica dissolved. A large watch glass was placed on top of the Teflon beaker, and the solution was stirred overnight at room temperature.

The binder was prepared by adding the dry materials in the following order: meta-kaolinite, furnace slag, sand, and sodium sulfide hydrate. These dry materials were blended for five minutes using a planetary mixer set at low speed then allowed to stand for five minutes. The Geopolymer paste was prepared by pouring the activator solution into the blended binder solids. Because of the large amount of blended dry materials and the size of the mixing bowl, the blended dry material was mixed with the activator solution in three separate stages for Geopolymer batch \#1. This was accomplished by mixing a portion of the dry blend with a portion of the activator solution until all of the ingredients were mixed. The batch size for Geopolymer batch \#2 was reduced by half, which allowed the dry materials and activator solution to mix together at one time as per procedure. From this point on, the following steps were conducted for both batches.

The Geopolymer paste was mixed at low speed until the activator solution was incorporated into the dry materials. The mixer speed was increased until the paste became thinner. While mixing, silver zeolite (Ag-zeolite) was sprinkled into the paste. Mixing continued until the Geopolymer paste was smooth and homogeneous. Total mixing time was approximately 10 minutes. Polycarbonate sleeves were used as molds for casting monoliths (in the same dimensions as Cast Stone). The molds were partially filled in the vertical position and vibrated until a significant decrease in the release of air bubbles 
was observed. Then, the molds were filled to near capacity and vibrated until no air bubbles were observed. The molds were covered with a perforated plastic cap for 24 hours at room temperature. The monoliths then were removed from the molds and allowed to air dry for 24 hours. Subsequently, the monoliths were placed into a plastic bag and sealed for 28 days at room temperature for a total cure time of 30 days. Batch \#1 produced 10, and batch \#2 produced five 2-inch diameter by 4 -inch length cylindrical samples of Geopolymer. Photos of the Geopolymer after curing are shown in Figure 3.2

Table 3.2. Material Specifications and Composition for Geopolymer Monoliths

\begin{tabular}{lccc}
\hline \multicolumn{1}{c}{ Material } & Addition Order & Batch \#1 & Batch \#2 \\
Amount Used (G) & Amount Used (G) \\
\hline Simulant & 1 & 798.5 & 399.25 \\
Tin fluoride & 2 & 3.0 & 1.5 \\
\hline Potassium hydroxide & 3 & 411.4 & 205.7 \\
Sodium hydroxide & 3 & 20.1 & 10.05 \\
Fumed silica & 4 & 463.8 & 231.9 \\
Meta-kaolinite & 5 & 813.3 & 406.7 \\
Furnace slag & 5 & 534.2 & 267.1 \\
Sand & 5 & 759.5 & 379.8 \\
Sodium sulfide hydrate & 5 & 5.0 & 2.5 \\
Silver zeolite & 6 & 20.0 & 10.0 \\
\hline
\end{tabular}
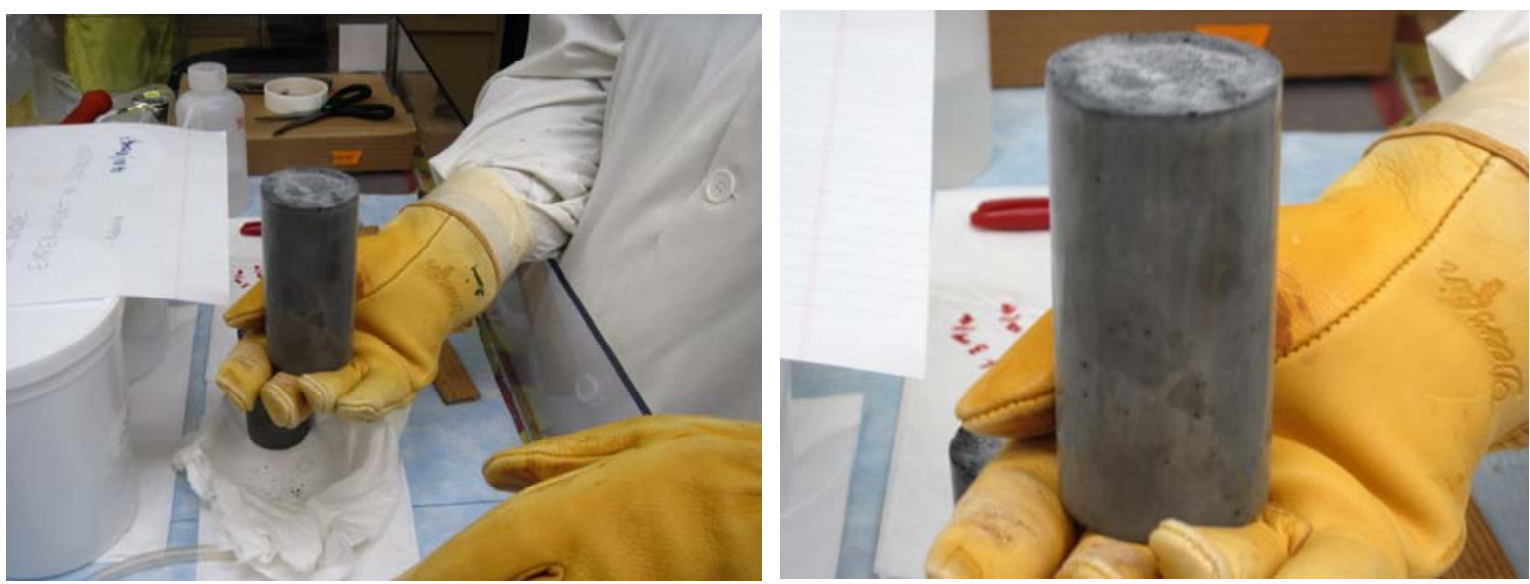

Figure 3.2. Picture of 30-Day Cured Geopolymer Monolith 


\subsection{Materials and Methods}

The materials and methods section describes the preparation techniques, approaches used for solution analyses and solids characterization, the experimental test methods used to evaluate the release of COC from Cast Stone and Geopolymer samples during the screening test, and approach used to calculate the Eh-pH diagrams for key metals and radionuclides.

\subsection{Material Preparation Techniques}

After the curing periods were complete, one of the four Cast Stone monoliths and one sample from each of the two Geopolymer batches were crushed to provide enough powdered sample material to determine the moisture content and specific surface area and for use in U.S. Environmental Protection Agency (EPA) Draft Methods 1313 and 1316, which are discussed in more detail later in this section. The powder samples of each waste form were prepared by separately breaking each monolith into large chunks with a hammer and placing the chunks into a ball mill to be reduced further. The crushed material was then sieved to $<0.3 \mathrm{~mm}$ diameter size fraction (US sieve $50 \mathrm{mesh}$ ).

After size reduction, a 10-gram aliquot of powder, the $<0.3$-mm material, was placed into a tared container and dried in an oven at $105^{\circ} \mathrm{C}$ until constant weight was achieved, which took at least 24 to 48 hours (ASTM 1998). Then, each container was removed from the oven, sealed, cooled, and reweighed. At least two weighings were conducted after a 24-hour heating period to verify that constant weight had been achieved. To verify balance performance prior to weighing the samples, all gravimetric measurements were performed with a calibrated balance that was checked with a calibrated weight set. The gravimetric water content was computed as the percent weight change of the powder sample before and after oven drying (i.e., [ \{wet weight - dry weight $\}$ /dry weight]). The oven-dried sample was used for surface area measurement and discarded.

The specific surface area (SSA) of an aliquot of the crushed $(<0.3-\mathrm{mm}$ sized particles) Cast Stone and each batch of Geopolymer were measured with a Micromeritics ASAP 2020 gas sorption surface-area analyzer using the $\mathrm{N}_{2}$ - Brunauer-Emmett-Teller (BET) method (Brunauer et al. 1938). Each sample was heated at $110^{\circ} \mathrm{C}$ under vacuum for a minimum of five hours to remove any physic-sorbed water from the material surface. The SSA was measured at liquid nitrogen temperature $(\sim 77 \mathrm{~K})$ to allow any $\mathrm{N}_{2}$ molecules to adsorb at the solid surface. The $<0.3-\mathrm{mm}$ size fractions resulted in a $\mathrm{N}_{2}$-BET surface area

measurement of $16.7 \pm 0.1 \mathrm{~m}^{2} / \mathrm{g}$ for Cast Stone and $30.8 \pm 0.1$ and $36.6 \pm 0.2 \mathrm{~m}^{2} / \mathrm{g}$ for Geopolymer batch \#1 and batch \#2, respectively.

\subsection{Liquid Characterization}

All leachate solutions were monitored for $\mathrm{pH}$, oxidation-reduction potential (Eh), electrical conductivity (EC), alkalinity, major anions, major cations, and trace metals. The $\mathrm{pH}$ of the solution samples was measured with a solid-state $\mathrm{pH}$ electrode and a $\mathrm{pH}$ meter (Hanna, model HI 4521). Prior to measurement, the $\mathrm{pH}$ probe was calibrated with National Bureau of Standards (NBS) buffers $(\mathrm{pH}=2.00$, $4.00,7.00,10.00$, and/or 12.00 at $25^{\circ} \mathrm{C}$ ). Precision of the $\mathrm{pH}$ measurement was $\pm 0.1 \mathrm{pH}$ units. An Eh probe (Hanna, 3131B) was used to measure the Eh of leachate solutions. The Eh probe was calibrated 
using $\mathrm{pH}$ buffer solution $\left(\mathrm{pH}=4.00\right.$ and 7.00 at $25^{\circ} \mathrm{C}$ ) mixed with $0.5 \mathrm{~g}$ of quinhydrone. The Eh values discussed in this report are the corrected measured Eh values using Equation (1).

$$
E h=E h_{\text {measured }}+208 m V
$$

A Pharmacia Biotech conductivity sensor was used to measure the EC of leachate solutions. The sensor was calibrated with a range of freshly prepared potassium chloride standard solutions, ranging from $0.001 \mathrm{M}$ to $1.0 \mathrm{M}$. Approximately $2 \mathrm{~mL}$ to $3 \mathrm{~mL}$ of filtered leachate was used to measure the electrical conductivity. Alkalinity $\left(\mathrm{mg} / \mathrm{L}\right.$ as $\left.\mathrm{CaCO}_{3}\right)$ was measured using a standard acid titration method (total alkalinity at $\mathrm{pH}=4.5$ ). The alkalinity procedure is equivalent to the U.S. Geological Survey method in the National Field Manual for the Collection of Water-Quality Data (USGS 2004).

The concentrations of nitrate $\left(\mathrm{NO}_{3}{ }^{-}\right)$, phosphate $\left(\mathrm{PO}_{4}^{-3}\right)$, and sulfate $\left(\mathrm{SO}_{4}^{-2}\right)$ in leachate solutions were determined using ion chromatography (IC) with a Dionex AS17 column. This methodology is based on EPA Method 300.0A (EPA 1984), with the exception of using the gradient elution of sodium hydroxide. The concentration of major cations was measured with inductively coupled plasma optical emission spectroscopy (ICP-OES) using high-purity calibration standards to generate calibration curves and verify continuing calibration during the analysis run. Because of the differences in the leachate cation concentration, a number of dilutions, ranging from 100 to 1.01 times, were used to obtain measurable concentrations of the cations of interest. Details of this method are found in EPA Method 6010B (EPA 2000a). Inductively coupled plasma mass spectrometry (ICP-MS) was used to measure trace metals concentrations, including iodine, mercury, and ${ }^{99} \mathrm{Tc}$. These measurements were performed following the PNNL-AGG-415 method (PNNL 1998), which is similar to EPA Method 6020 (EPA 2000b).

\subsection{Solid Characterization}

The composition of a portion of the raw materials used to make Cast Stone and Geopolymer, as well as aliquots of the $<0.3 \mathrm{~mm}$ crushed 28-day cured Cast Stone and 30-day cured Geopolymer samples, was chemically digested to determine the elemental composition. Microwave-assisted strong acid digestions were conducted using $16 \mathrm{M} \mathrm{HNO}_{3}(\sim 17 \mathrm{wt} \%), 12 \mathrm{M} \mathrm{HCl}(7 \mathrm{wt} \%), 32 \mathrm{M} \mathrm{HF}(3.3 \mathrm{wt} \%), 0.5$ grams of $\mathrm{H}_{3} \mathrm{BO}_{3}(1.5 \mathrm{wt} \%)$, and DI water (71.2 wt \%). The powdered samples were prepared following the PNNLAGG-MARS-001 (PNNL 2009b), which is modified from EPA Method 3052 (EPA 1996). The solidacid mixture $(0.35 \mathrm{~g} / 30 \mathrm{~mL})$ was typically reacted for one hour at $90 \pm 5^{\circ} \mathrm{C}$. In the case of the 30 -day cured Geopolymer samples, a slight deviation was made because of the presence of undissolved solids using the typical approach. For these samples, the reaction time was extended to between two and three hours, and the solid-to-acid ratio was reduced $(0.1 \mathrm{~g} / 30 \mathrm{~mL})$. Upon complete dissolution of the sample, the resulting solution was centrifuged, filtered through a $0.45-\mu \mathrm{m}$ membrane, and analyzed for ${ }^{99} \mathrm{Tc}$ and trace metals using ICP-MS and major cations and a limited number of nonmetals (e.g., phosphorus and sulfur) using ICP-OES. This method is not appropriate for anion concentrations (e.g., $\mathrm{NO}_{3}$, chlorine, fluorine, and $\mathrm{BO}_{3}$ ) due to the acids used in the dissolution procedure.

A separate chemical digestion is necessary to determine the iodide concentration in these samples because iodide can oxidize and volatilize at low $\mathrm{pH}$. Therefore, to minimize volitization, an alkaline fusion was used to determine total iodide concentration in the powder samples (PNNL 2006). The sample was mixed with $\mathrm{KOH}-\mathrm{KNO}_{3}$ fusion solution in a crucible and heated at about $550^{\circ} \mathrm{C}$ for one hour. The final fusion melt was cooled and acidified with $\mathrm{HNO}_{3}$. Sodium bisulfite also was added to prevent 
oxidation of iodide to elemental iodine in the final solution. The final solution was filtered and submitted for iodide analysis using ICP-MS.

In addition to determining the chemical composition of the solid waste forms, X-ray diffraction (XRD) and scanning election microscopy (SEM) with energy dispersive spectrometry (EDS) were used to characterize a portion of the raw material and the pre- and post-test 28-day cured Cast Stone and 30-day cured Geopolymer samples. X-ray diffractograms were collected using a Phillips X'Pert X-ray diffractometer with $\mathrm{Cu}-\mathrm{K} \alpha$ radiation $\mathrm{X}$-ray tube $(\lambda=1.5418 \AA)$ and a graphite monochrometer. Data were collected from 2 to $65^{\circ} 2 \theta$ with a scanning step size $0.05^{\circ}$ and dwell time of four seconds. Before mounting a representative sample, the bulk material was ground with an agate mortar and pestle and mounted in the XRD holder. A specialized XRD holder was used for samples that contain radioactive constituents (Strachan et al. 2003). The electronic scans were processed using JADE ${ }^{\circledR}$ software (Materials Data Inc., Livermore, California). A database published by the Joint Committee on Powder Diffraction Standards (JCPDS) International Center for Diffraction Data (ICDD) (Newtown Square, Pennsylvania) was used to identify crystalline phases by comparing standard single phase patterns to the bulk XRD patterns measured for each sample. As a general rule, a crystalline phase must be present at greater than $\sim 5$ to $10 \mathrm{wt} \%$ of the total sample mass (greater than $1 \mathrm{wt} \%$ under optimum conditions) to be readily detected by $\mathrm{XRD}$.

Surface morphology and composition of solid phases present in the pre- and post-test Cast Stone and Geopolymer samples were analyzed with SEM combined with EDS measurements. For these analyses, an aliquot of sample was mounted with double-sided carbon tape attached to an aluminum stub. After being mounted, each sample was coated with carbon using a vacuum sputter-coater to improve the conductivity of the samples and the quality of the SEM images and EDS signal. The SEM used to provide images of these samples was a JEOL JSM-840 with a LaB 6 filament. An INCA Energy EDS System was used to collect EDS spectra for qualitative elemental analysis of scanned particles. The EDS system consists of an Oxford $\mathrm{Si}(\mathrm{Li})$ detector that operates with a beam current of $30 \mathrm{nA}$.

\subsection{Screening Tests}

The specific test methods used to screen the candidate waste forms need to provide a framework to 1) rapidly assess material performance, 2) provide some indication of the dominant release mechanism for each COC, 3) evaluate the strengths and weaknesses of a variety of materials (placing each material on a level playing field), and 4) gain regulatory acceptance by being a standard set of test methods approved by the regulatory community. Although these aforementioned criteria focus on the use of standard methods, these analyses need to be augmented with the specialized characterization techniques previously discussed to examine key processes affecting the release of COC from the waste form that correlates with changes in the measured leachate solution chemistry (increase in concentration of key COC). This type of integrated approach is expected to provide the defense in depth needed to evaluate each of the candidate liquid stabilization options effectively in order to support the decision for further testing.

To address the stated criteria, three draft test methods being developed for the EPA were used to screen each stabilization technology. Each method examines different aspects of material performance. These methods are currently undergoing EPA approval and are expected to be used in place of the TCLP method for disposal of specific materials, such as waste forms. Each test method used-Draft Methods 1313, 1315, and 1316 - are discussed as follows. It is also noted that the methods used in this report only 
provide metrics of relative performance for each candidate waste form that aids in evaluation of whether the candidate waste forms can meet final acceptance criteria.

\subsubsection{EPA Method 1313}

The EPA Method 1313 (Liquid-Solid Partitioning as a Function of Extract $\mathrm{pH}$ ) is a static test method where a set of parallel extraction experiments are conducted in dilute acid or base laden DI water at a fixed $\mathrm{pH}$ ( $\mathrm{pH}$ range from 4 to 12) and fixed liquid-to-solid ratio $(10 \mathrm{~mL} / \mathrm{g})$ (EPA 2009a). Prior to initiating the static test, a series of pre-titrations were conducted at a fixed liquid-to-solid ratio $(10 \mathrm{~mL} / \mathrm{g})$ using $<0.3$-mm sized material. After a 24-hour period of mixing in the absence of acid or base additions, the sample slurry was centrifuged, the supernatant was removed, and it was used to determine the equilibrated $\mathrm{pH}$. Since the measured $\mathrm{pH}$ of the leachate solutions for Cast Stone and Geopolymer were high ( $\mathrm{pH} \sim 12$ to 13), a pre-titration was develop based upon dilute $\mathrm{HNO}_{3}$ additions to decrease the $\mathrm{pH}$ from 12 to lower targeted values after 24 hours of equilibration. Analytical grade $\mathrm{HNO}_{3}$ (Optima) was used to prepare a solution of $2 \mathrm{~N} \mathrm{HNO}_{3}$ for these experiments. Based upon the pre-titration results, test samples were prepared by mixing $10 \mathrm{~g}$ of $<0.3-\mathrm{mm}$ sized material with a predetermined amount of $2 \mathrm{~N}$ $\mathrm{HNO}_{3}$ and bringing the samples to volume with DI water. All samples were placed on a platform shaker and allowed to mix at room temperature $\left(23 \pm 2^{\circ} \mathrm{C}\right)$ for 24 hours. After mixing, the extractant vessels were centrifuged (minimum at $4000 \pm 100$ RPM) for $10 \pm 2$ minutes, and the decanted clear supernatant $(\sim 5$ $\mathrm{mL}$ ) was used to measure the solution $\mathrm{pH}$, electrical conductivity, and redox potential. The remaining solution was filtered using a $0.45-\mu \mathrm{m}$ polypropylene membrane syringe filter and submitted for additional chemical analyses.

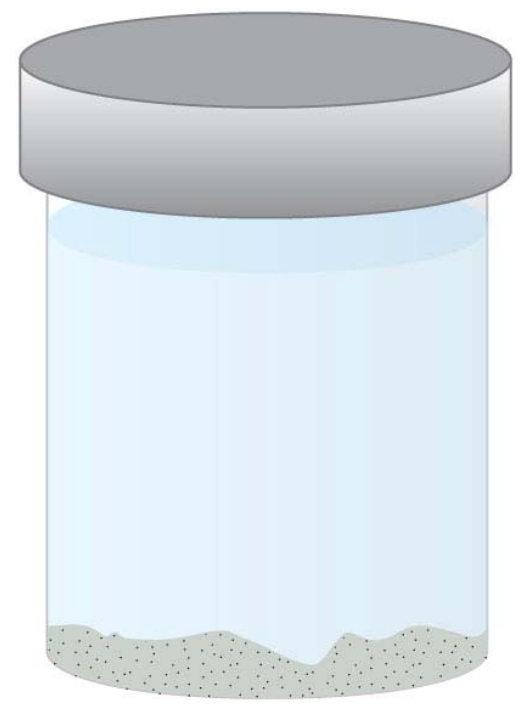

Figure 4.1. An Example of the Type of Static Container Used to Conduct the EPA 1313 and 1316 Test Methods

\subsubsection{EPA Method 1316}

Similar to 1313, EPA Method 1316 (Liquid-Solid Partitioning as a Function of Liquid to Solid Ratio) also is a static test method that uses DI water as the leachant instead of a dilute acid or base at a variety of liquid-to-solid ratios (EPA 2009b). The purpose of this test method is to evaluate the effect of differing 
liquid-to-solid ratios on the release of contaminants. These experiments were conducted by adding DI water to the test vessel containing a predetermined amount of powdered material $(<0.3 \mathrm{~mm})$. These experiments were conducted at three different liquid-to-solid ratios $(10,5$, and $2 \mathrm{~mL} / \mathrm{g})$. After preparation, all the samples were placed on a platform shaker and allowed to mix for 24 hours. After the 24-hour contact time was complete, the slurry samples were centrifuged and clear supernatants were used to measure the solution $\mathrm{pH}$, electrical conductivity, and redox potential. Remaining solution samples were filtered using a syringe filter $(0.45-\mu \mathrm{m}$ size polypropylene membrane), and the filtrate was submitted for additional chemical analyses.

\subsubsection{EPA Method 1315}

The EPA Method 1315 (Mass Transfer Rates of Constituents in Monolith or Compacted Granular Materials) is a 63-day semi-dynamic leach experiment that consists of submerging a monolithic sample (with a fixed geometry) in DI water at a fixed liquid volume-to-solid surface area ratio and sampling at fixed periods of time as cumulative leaching times 0.08, 1, 2, 7, 14, 28, 42, 49, and 63 days (EPA 2009c). At each sampling interval the leaching fluid is removed and replaced with fresh fluid. A schematic of this process is shown in Figure 4.2.

The geometric surface area is used in this test method and calculated based on the cylindrical dimensions of the sample. The average calculated geometric surface area was $0.0178 \pm 0.001 \mathrm{~m}^{2}$ for Cast Stone and $0.0181 \pm 0.003$ and $0.0177 \pm 0.002 \mathrm{~m}^{2}$ for Geopolymer batch \#1 and batch \#2, respectively. At each of the nine pre-determined leaching intervals, sample mass is recorded, and the leaching solution is changed. This method is similar to ANSI/ANS 16.1 (ANSI 1986), but the leaching intervals are modified, and the process of mass transfer can be interpreted by more complex release models that account for physical retention of the porous medium and chemical retention at the pore wall through geochemical speciation modeling.

The cylindrical monolith sample (2-inch diameter by 4-inch height) was placed into the center of a leaching vessel and mixed with DI water to maintain a solid-to-solution ratio of $9 \pm 1 \mathrm{~mL}$ of eluant per $\mathrm{cm}^{2}$ of sample. The sample stand and holder were used to maximize contact area of the sample with the leaching solution. In between the sampling/replacement intervals, the experimental vessels were covered with a lid. An example of the experimental setup and sample specimens in the leaching vessels are shown in Figure 4.3. The leaching times at which solution exchanges were made for these experiments were: 2 hours, 1, 2, 7, 14, 28, 42, 49, and 63 days. Leachate samples collected during these intervals were used to measure $\mathrm{pH}$, electrical conductivity, and redox potential. Before submitting for chemical analyses, the samples were also filtered using a $0.45-\mu \mathrm{m}$ syringe filter. 


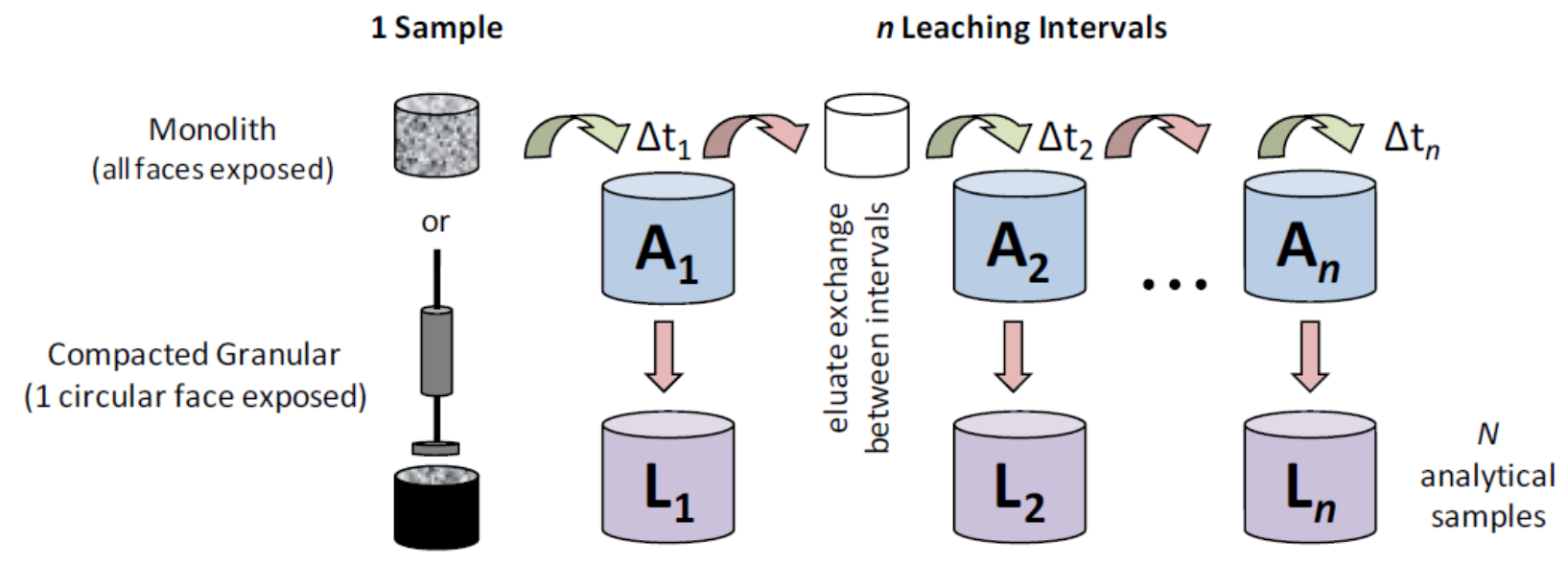

Figure 4.2. Schematic of 1315 Test Method
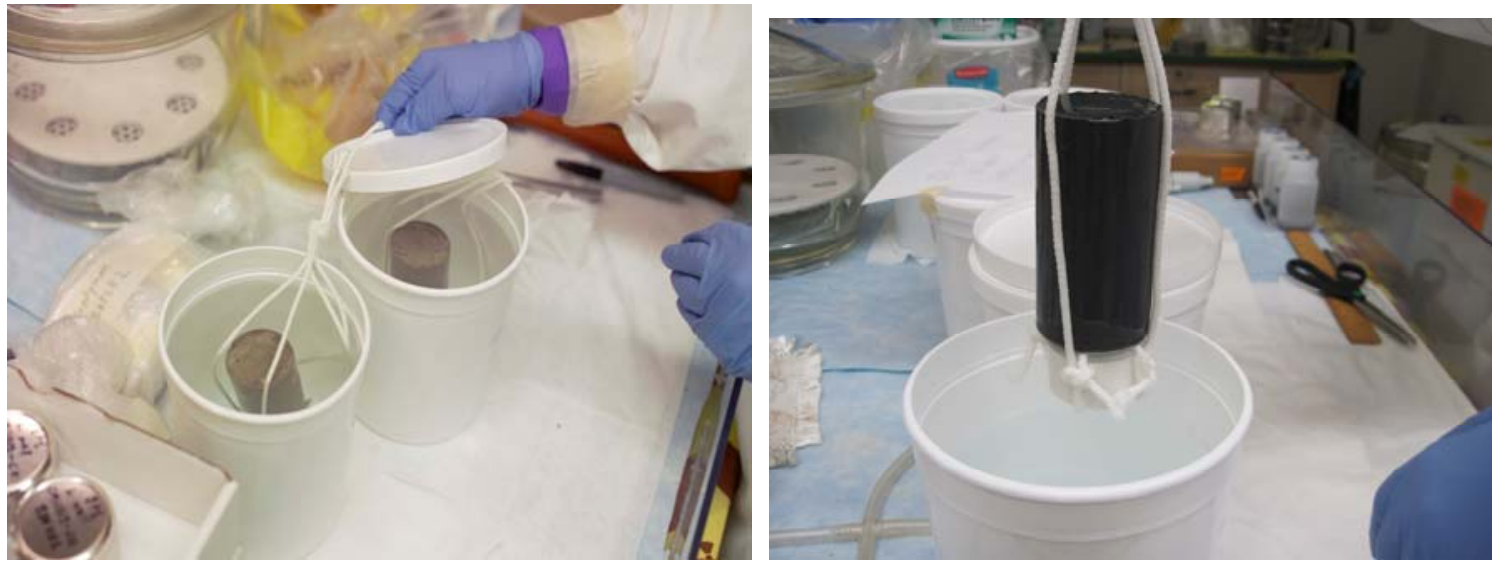

Figure 4.3. Duplicate Monoliths of Cast Stone Submerged into DI Water in the Leaching Vessels with the Lids (Left). The same setup was used for the 1315 test on Geopolymer samples (right).

The observed diffusivity for each constituent was calculated using the analytical solution, Equation 1, for simple radial diffusion from a cylinder into an infinite bath as presented by Crank (1986).

$$
D_{i}=\pi\left[\frac{M_{t_{i}}}{2 \rho C_{o}\left(\sqrt{t_{i}}-\sqrt{t_{i-1}}\right)}\right]^{2}
$$

where $\mathrm{D}_{i}$ is observed diffusivity of a specific constituent for leaching interval, $i\left[\mathrm{~m}^{2} / \mathrm{s}\right] ; \mathrm{M}_{t i}$ is mass released during leaching interval $i\left[\mathrm{mg} / \mathrm{m}^{2}\right] ; t_{i}$ is cumulative contact time after leaching interval, $i[\mathrm{~s}] ; \mathrm{t}_{i-1}$ is cumulative contact time after leaching interval, $i-1[\mathrm{~s}] ; \mathrm{C}_{\mathrm{o}}$ is initial leachable content $[\mathrm{mg} / \mathrm{Kg}]$; and $\rho$ is sample density $\left[\mathrm{Kg}\right.$-dry $\left./ \mathrm{m}^{3}\right]$. The mean observed diffusivity for each constituent can be determined by taking the average of the interval observed diffusivity with the standard deviation. The Leachability Index (LI), the parameter derived directly from immersion test results evaluates diffusion-controlled contaminant release with respect to time. The LI is used as a performance criterion to assess whether solidified/stabilized waste will likely be acceptable for subsurface disposal in waste repositories. In most 
cases, the solidified waste is considered effectively treated when the LI value is equal to or greater than nine. The LI is calculated with Equation (3)

$$
L I_{n}=-\log \left(\frac{D_{n}}{c m^{2} s}\right)
$$

where $L I$ is the leach index, and $D_{n}$ is the effective diffusivity for elements of interest $\left(\mathrm{cm}^{2} / \mathrm{s}\right)$ during the leach interval $n$.

\subsection{Calculation of Eh-pH diagrams}

The Eh and $\mathrm{pH}$ conditions and associated complexation reactions are key parameters for understanding the solubility and environmental behavior of $\mathrm{Tc}, \mathrm{I}, \mathrm{Hg}, \mathrm{Cr}$, and $\mathrm{Ag}$. To show the impact of these parameters on the geochemistry of these contaminants, the distributions of dominant aqueous species and potential solubility controls were calculated as a function of $\mathrm{pH}$ and Eh with computer modeling-based equilibrium thermodynamic principals. The results of these speciation and solubility calculations are presented graphically here as Eh-pH diagrams for Tc in Section 5.2 and in the Appendix $\mathrm{F}$ for the other elements. The diagrams were constructed assuming the cast stone leachant chemistry measured at 14 days. Diagrams constructed using leachant chemistries measured for duralith batch \#1 and duralith batch \#2 at 14 days were indistinguishable from those of the cast stone.

The theory behind the calculation of Eh-pH predominance diagrams is discussed by Garrels and Christ (1965), Langmuir (1997), Nordstrom and Munoz (1985), and others. The Eh-pH diagrams were calculated at $25^{\circ} \mathrm{C}(298 \mathrm{~K})$ and $1 \mathrm{~atm}$ pressure using the The Geochemist's Workbench ${ }^{\circledR}$ (Version 7.0.2) software package and the expanded thermodynamic database file "thermo.com.V8.R6+.dat" provided with the software package. The Lawrence Livermore National Laboratory (LLNL) developed the thermodynamic database file originally for use with the EQ3/6 geochemical model.

Each Eh-pH diagram in this appendix contains dashed black lines from coordinates (Eh 1.2 $\mathrm{V}-\mathrm{pH} 0$ ) to (Eh $0.4 \mathrm{~V}-\mathrm{pH} 14)$ and from (Eh $0.0 \mathrm{~V}-\mathrm{pH} 0$ to Eh $-0.8 \mathrm{~V}-\mathrm{pH} 14)$ that represent the Eh-pH boundaries for the dissociation of water to its gaseous components at $25^{\circ} \mathrm{C}$ and $1 \mathrm{~atm}$ pressure. At Eh-pH values above the upper black dashed line, water breaks down to oxygen gas. At Eh-pH values below the lower black dashed line, water breaks down to hydrogen gas. The redox conditions for essentially all environmental systems occur in the region within these water-stability limits. 


\subsection{Results}

This section presents the data from the analysis of the Cast Stone and Geopolymers samples. Results from chemical and crystalline characterization of the raw materials and each waste form are included. In addition to the characterization results, data from the EPA 1313, 1315, and 1316 leach methods are also presented.

\subsection{Solids Characterization}

The raw materials used to prepare the waste forms and the 28-day cured Cast Stone and 30-day cured Geopolymer samples were characterized with respect to their crystalline and chemical composition using a variety of techniques including chemical digestion, XRD, and SEM with EDS. The results from these analyses are discussed in the sections that follow.

\subsubsection{Cast Stone}

The elemental composition of the raw materials used to prepare the Cast Stone samples are shown in Table 5.1. The amount of silver, boron, chromium, mercury, potassium, magnesium, lead, silicon, and zirconium present in fly ash, BFS, and Portland cement are comparable to one another with ratio of elemental concentration ranging from 1.0 to 4.8. For example, the concentration of lead ranges from 7.18 to $21.5 \mu \mathrm{g} / \mathrm{g}$, with the highest concentration being present in fly ash. A larger difference exists when comparing the remaining elements (aluminum, barium, calcium, copper, iron, manganese, sodium, phosphorus, sulfur, tin, strontium, titanium, vanadium, and zinc) contained in each of the raw materials. This is largely because the elemental concentrations may be comparable in two ingredients but differ significantly when these values are compared to the value for the third raw ingredient. For example, the sulfur concentration in BFS $\left(1.47 \times 10^{4} \mu \mathrm{g} / \mathrm{g}\right)$ and fly ash $\left(1.24 \times 10^{4} \mu \mathrm{g} / \mathrm{g}\right)$ are comparable, but these values are an order of magnitude greater than the amount present in Portland cement $\left(1.01 \times 10^{3} \mu \mathrm{g} / \mathrm{g}\right)$. In this section the word "comparable" is being used qualitatively and refers to situations where the elemental concentrations for each raw ingredient are within an order of magnitude of one another. The results in Table 5.1 also show a portion of the total amount of several RCRA metals contained in the Cast Stone originates from the raw materials. For example, approximately $58.4 \mathrm{wt} \%$ of silver originates from the simulant with the remaining amount of silver originating from fly ash $(22.5 \mathrm{wt} \%)$, BFS (14.7 wt $\%)$, and Portland cement $(4.3 \mathrm{wt} \%)$. Fly ash contributes approximately $33.4 \mathrm{wt} \%$ of the total mercury with the remaining amounts originating from the simulant (50.4 wt\%), BFS (10.6 wt\%), and Portland cement (5.6 $\mathrm{wt} \%)$. The majority of chromium originates from fly ash $(66.6 \mathrm{wt} \%)$ and BFS $(24.0 \mathrm{wt} \%)$ with minor contributions from Portland cement $(6.2 \mathrm{wt} \%)$ and the simulant $(3.2 \mathrm{wt} \%)$. The majority of cadmium comes from the simulant $(99.2 \mathrm{wt} \%)$. Approximately $50.4 \mathrm{wt} \%$ of the total mercury originates from the simulant with the remainder coming from fly ash (33.4 wt\%), BFS (10.6 wt\%), and Portland cement (5.6 $\mathrm{wt} \%)$. The majority of lead comes from fly ash $(54.1 \mathrm{wt} \%)$ with smaller contributions from BFS (18.9 $\mathrm{wt} \%$ ), simulant (17.5 wt\%), and Portland cement (9.5 wt\%). Some caution must be taken not to over interpret these results. The COC percent release that originates from a specific phase versus the simulant is unclear and cannot be determine from the results provided in this document. 
Table 5.1. Chemical Composition, in $\mu \mathrm{g} / \mathrm{g}$, of Raw Materials-Fly Ash, Blast Furnace Slag, and Portland Cement - and 28-Day Cured Cast Stone

\begin{tabular}{|c|c|c|c|c|}
\hline Elements & Fly Ash & Blast Furnace Slag & Portland Cement & Cast Stone \\
\hline Tc & $\mathrm{NA}^{(\mathrm{a})}$ & NA & NA & $1.60 \mathrm{E}-01$ \\
\hline $\mathrm{Al}$ & $4.87 \mathrm{E}+03$ & $1.10 \mathrm{E}+04$ & $8.97 \mathrm{E}+04$ & $2.64 \mathrm{E}+04$ \\
\hline $\mathrm{Ag}$ & $2.05 \mathrm{E}+00$ & $1.28 \mathrm{E}+00$ & $2.20 \mathrm{E}+00$ & $3.15 \mathrm{E}+00$ \\
\hline As & $<7.99 \mathrm{E}-03$ & $<7.99 \mathrm{E}-03$ & $1.50 \mathrm{E}+01$ & $6.93 \mathrm{E}+00$ \\
\hline $\mathrm{Ba}$ & $2.45 \mathrm{E}+02$ & $4.70 \mathrm{E}+02$ & $2.18 \mathrm{E}+03$ & $1.18 \mathrm{E}+03$ \\
\hline $\mathrm{Ca}$ & $4.67 \mathrm{E}+05$ & $2.28 \mathrm{E}+05$ & $4.74 \mathrm{E}+04$ & $1.18 \mathrm{E}+05$ \\
\hline $\mathrm{Cd}$ & $<1.32 \mathrm{E}-03$ & $<1.32 \mathrm{E}-03$ & $<1.32 \mathrm{E}-03$ & $1.27 \mathrm{E}+01$ \\
\hline $\mathrm{Cr}$ & $6.87 \mathrm{E}+01$ & $2.37 \mathrm{E}+01$ & $3.60 \mathrm{E}+01$ & $3.73 \mathrm{E}+01$ \\
\hline $\mathrm{Cu}$ & $1.16 \mathrm{E}+02$ & $5.00 \mathrm{E}+00$ & $1.20 \mathrm{E}+02$ & $8.61 \mathrm{E}+01$ \\
\hline $\mathrm{Fe}$ & $2.01 \mathrm{E}+04$ & $4.74 \mathrm{E}+03$ & $3.97 \mathrm{E}+04$ & $2.19 \mathrm{E}+04$ \\
\hline $\mathrm{Hg}$ & 7.14E-02 & 2.17E-02 & 6.69E-02 & $3.83 \mathrm{E}-01$ \\
\hline I & $<5.75 \mathrm{E}-01$ & $<5.75 \mathrm{E}-01$ & $<5.75 \mathrm{E}-01$ & $<5.75 \mathrm{E}-01$ \\
\hline K & $2.13 \mathrm{E}+03$ & $2.26 \mathrm{E}+03$ & $4.17 \mathrm{E}+03$ & $3.83 \mathrm{E}+03$ \\
\hline $\mathrm{Mg}$ & $5.70 \mathrm{E}+03$ & $1.85 \mathrm{E}+04$ & $7.69 \mathrm{E}+03$ & $1.15 \mathrm{E}+04$ \\
\hline $\mathrm{Mn}$ & $5.16 \mathrm{E}+02$ & $2.47 \mathrm{E}+03$ & $3.22 \mathrm{E}+02$ & $1.23 \mathrm{E}+03$ \\
\hline $\mathrm{Na}$ & $3.74 \mathrm{E}+03$ & $1.46 \mathrm{E}+03$ & $3.23 \mathrm{E}+04$ & $2.03 \mathrm{E}+04$ \\
\hline $\mathrm{P}$ & $6.16 \mathrm{E}+02$ & $3.96 \mathrm{E}+02$ & $4.06 \mathrm{E}+03$ & $2.02 \mathrm{E}+03$ \\
\hline $\mathrm{Pb}$ & $2.15 \mathrm{E}+01$ & $7.18 \mathrm{E}+00$ & $2.13 \mathrm{E}+01$ & $4.67 \mathrm{E}+01$ \\
\hline $\mathrm{S}$ & $1.24 \mathrm{E}+04$ & $1.47 \mathrm{E}+04$ & $1.01 \mathrm{E}+03$ & $6.60 \mathrm{E}+03$ \\
\hline $\mathrm{Si}$ & $1.01 \mathrm{E}+05$ & $1.38 \mathrm{E}+05$ & $2.02 \mathrm{E}+05$ & $1.59 \mathrm{E}+05$ \\
\hline Sn & $6.01 \mathrm{E}+02$ & $4.59 \mathrm{E}+02$ & $9.16 \mathrm{E}+01$ & $3.20 \mathrm{E}+02$ \\
\hline $\mathrm{Sr}$ & $1.20 \mathrm{E}+03$ & $4.54 \mathrm{E}+02$ & $3.10 \mathrm{E}+03$ & $1.60 \mathrm{E}+03$ \\
\hline $\mathrm{Ti}$ & $1.59 \mathrm{E}+03$ & $3.24 \mathrm{E}+03$ & $2.34 \mathrm{E}+04$ & $1.12 \mathrm{E}+02$ \\
\hline V & $9.05 \mathrm{E}+01$ & $<4.57 \mathrm{E}-02$ & $4.88 \mathrm{E}+02$ & $2.01 \mathrm{E}+02$ \\
\hline $\mathrm{Zn}$ & $6.87 \mathrm{E}+02$ & $4.60 \mathrm{E}+01$ & $1.91 \mathrm{E}+02$ & $1.60 \mathrm{E}+02$ \\
\hline $\mathrm{Zr}$ & $3.88 \mathrm{E}+02$ & $1.86 \mathrm{E}+02$ & $8.93 \mathrm{E}+02$ & $4.96 \mathrm{E}+02$ \\
\hline
\end{tabular}

(a) NA-not analyzed because technetium-99 is likely not present in the raw ingredients.

Powder XRD measurements were performed on the three raw ingredients used to prepare samples and a 28-day cured sample of Cast Stone. The measured XRD patterns are shown in Figure 5.1 along with the standard mineral powder diffraction files $\left(\mathrm{PDF}^{\mathrm{TM}}\right)$. The BFS pattern (Figure 5.1a) illustrates that the majority of the material is amorphous, as evident by the large peak centered near $30.0^{\circ} 2 \theta$, and contains a minor amount of crystalline phases. The crystalline phases identified in the BFS were quartz (PDF\#00-046-1045, $\mathrm{SiO}_{2}$ ), evident by the 100 percent peak near $26.7^{\circ} 2 \theta$. In addition to quartz, minor amounts of gypsum (PDF\# 01-076-1746, $\mathrm{CaSO}_{4} \bullet\left(\mathrm{H}_{2} \mathrm{O}\right)_{2}$ ) and calcite (PDF\# 99-000-0548, $\mathrm{CaCO}_{3}$ ) were also identified and have 100 percent peaks near 11.6 and $29.5^{\circ} 2 \theta$, respectively. Similar to the BFS, the fly ash (Figure 5.1b) XRD patterns also reveal that this material is mainly amorphous with minor amounts of crystalline phases. The peak near $26.7^{\circ} 2 \theta$ was identified as quartz (PDF\#00-046-1045, $\left.\mathrm{SiO}_{2}\right)$. 
Identification of the peak near $35.5^{\circ} 2 \theta$ may be magnetite (PDF\# 00-019-0629, $\mathrm{Fe}_{3} \mathrm{O}_{4}$ ). However, this is not certain. Portland cement type I/II was the only raw ingredient used to prepare Cast Stone that contained significant quantities of crystalline material. Calcium silicate (PDF\# 00-055-0740, $\mathrm{Ca}_{3} \mathrm{SiO}_{5}$ ) was the dominant crystalline phase identified in the XRD pattern (see Figure 5.1c), which is typical of Portland cement. Although additional Rietveld refinements (Rietveld 1965) are needed for conclusive identification, these results further suggests the dominant form of calcium silicate present is the monoclinic type-2 polymorph. Additionally, a minor amount of dolomite (PDF\# 98-000-0200, $\left.\mathrm{MgCa}\left(\mathrm{CO}_{3}\right)_{2}\right)$ was also observed in the Portland cement.

The XRD results for the 28-day cured Cast Stone sample are also displayed in Figure 5.1d. The broad diffraction pattern indicates that the Cast Stone is mostly amorphous with a minor amount of crystalline phases. Semi-quantitative analysis of the pattern suggests that $>88$ to $95 \mathrm{wt} \%$ amorphous phases are present with less than $12 \mathrm{wt} \%$ crystalline material. The crystalline phases identified in the Cast Stone were ettringite (PDF\# 00-041-1451, $\mathrm{Ca}_{6} \mathrm{Al}_{2}\left(\mathrm{SO}_{4}\right)_{3}(\mathrm{OH})_{12} \cdot 26 \mathrm{H}_{2} \mathrm{O}$ ) and calcite (PDF\# 00-047-1743, $\mathrm{CaCO}_{3}$ ). Of the two unidentified peaks at 11.0 and $26.7^{\circ} 2 \theta$, the latter peak is most likely associated with the presence of unreacted quartz that originated from the dry ingredients, but the identity of the remaining peak $\left(11.0^{\circ} 2 \theta\right)$ is still unclear.
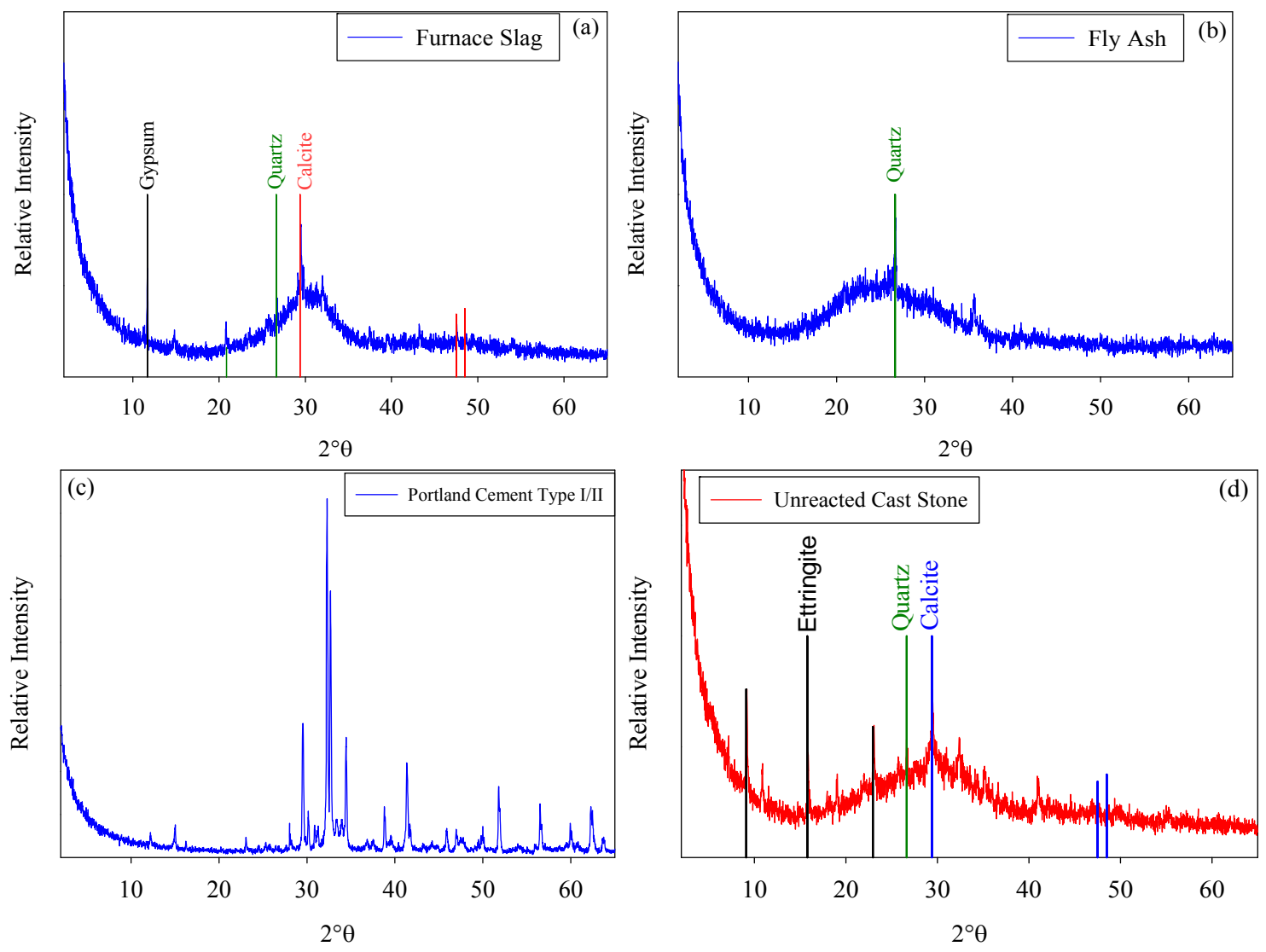

Figure 5.1. X-Ray Diffraction Patterns for Raw Materials_BFS (a), Fly Ash (b), and Portland Cement Type II (c) - and 28-Day Cured Cast Stone (d)

The powdered subsample of 28-day cured Cast Stone was taken from a monolith sample that was crushed for solids characterization to be used in EPA Methods 1313 and 1316. Sample mount preparation 
and SEM/EDS analyses were completed as described in Section 4.3. Appendix D contains all the preand post-test SEM micrographs and the tabulations of the elemental compositions derived from the EDS analyses of the raw materials and Cast Stone.

Figure 5.2 is a low magnification image showing the field of BFS grains mounted on double-sided carbon tape displayed as a black background in the image. Analysis of the SEM micrograph indicates that many of the particles are less than $10 \mu \mathrm{m}$ and vary considerably in their morphology, which is a result of the production process. Blast furnace slag is produced by quenching molten iron slag (a byproduct of iron and steel production processes) from a blast furnace in water or steam to produce a glassy, granular product that is then dried and ground to fine powder. The EDS spectrum of BFS suggests a significant amount of calcium, silicon, and aluminum with minor amounts of magnesium, sulfur, potassium, titanium, and manganese. The "C" peak (represents carbon) shown in the spectrum is the result of sample preparation. The large amount of calcium, silicon, and aluminum observed in the EDS spectra is consistent with the chemical digestion results discussed earlier in this section.

A low magnification image of a cluster of fly ash grains is shown in Figure 5.3. This image reveals the morphology of the unreacted fly ash is primarily spherical with a range of particle sizes. The shape and morphology of the fly ash particles are typical and the results of how these particles are produced. Fly ash is a residue material generated in the combustion of coal and solidifies while suspended in exhaust gases. The EDS spectrum reveals a high silicon and Al content for the spherical particles that contain a minor amount of calcium, iron, sodium, magnesium, and titanium. Based upon the amorphous XRD pattern, chemical digestion, and SEM/EDS, one can conclude these spherical particles are mainly an amorphous $\mathrm{SiO}_{2}$ phase that has become a host matrix for other cations and mineral phases. 


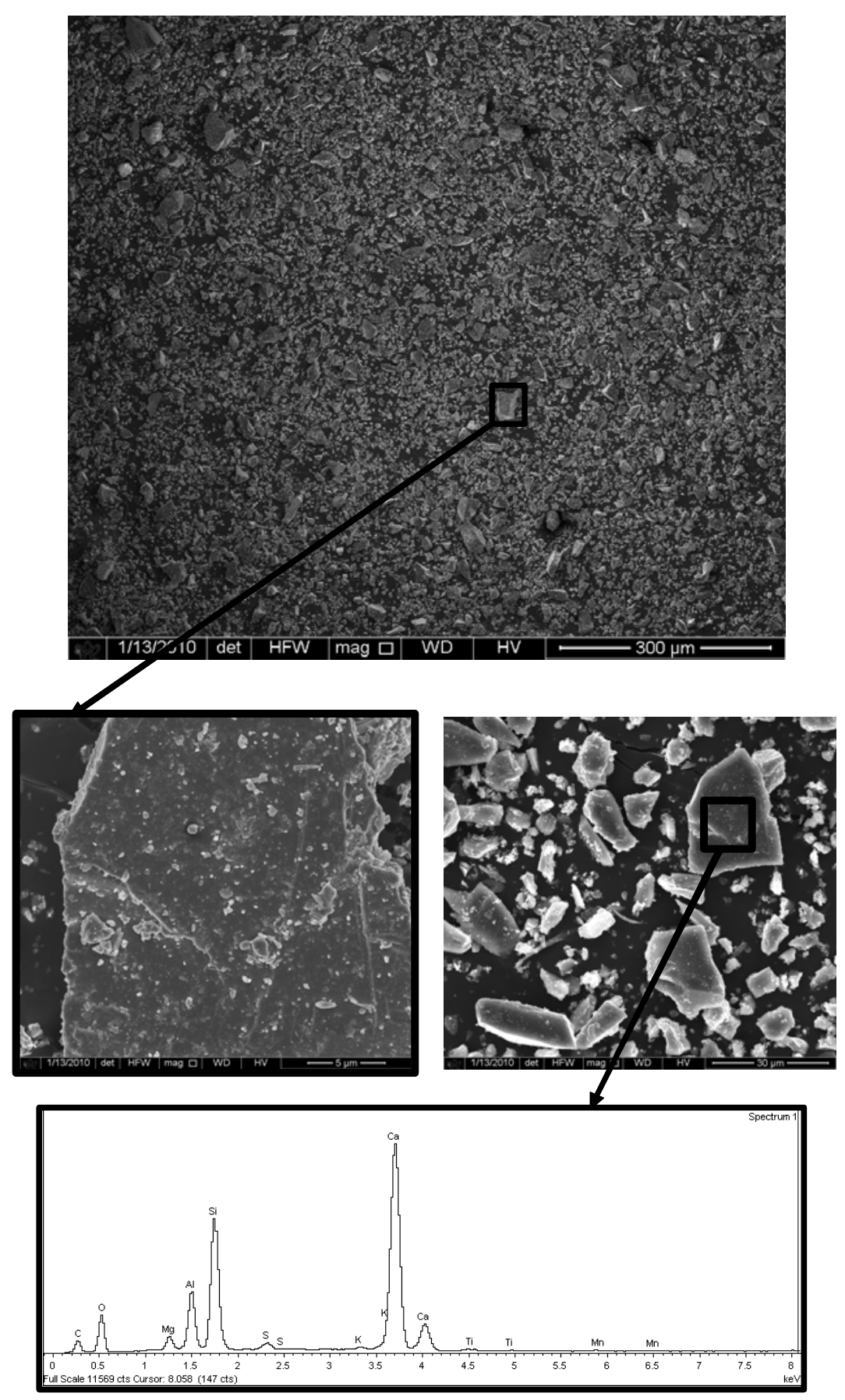

Figure 5.2. Blast Furnace Slag SEM Image and EDS Spectra. The top image is at low magnification $(\sim 300 \mu \mathrm{m})$ with an increased magnification of a single grain at $5 \mu \mathrm{m}$ (center left). The additional image (center right) was used to collect EDS spectra of a grain of BFS (bottom). 


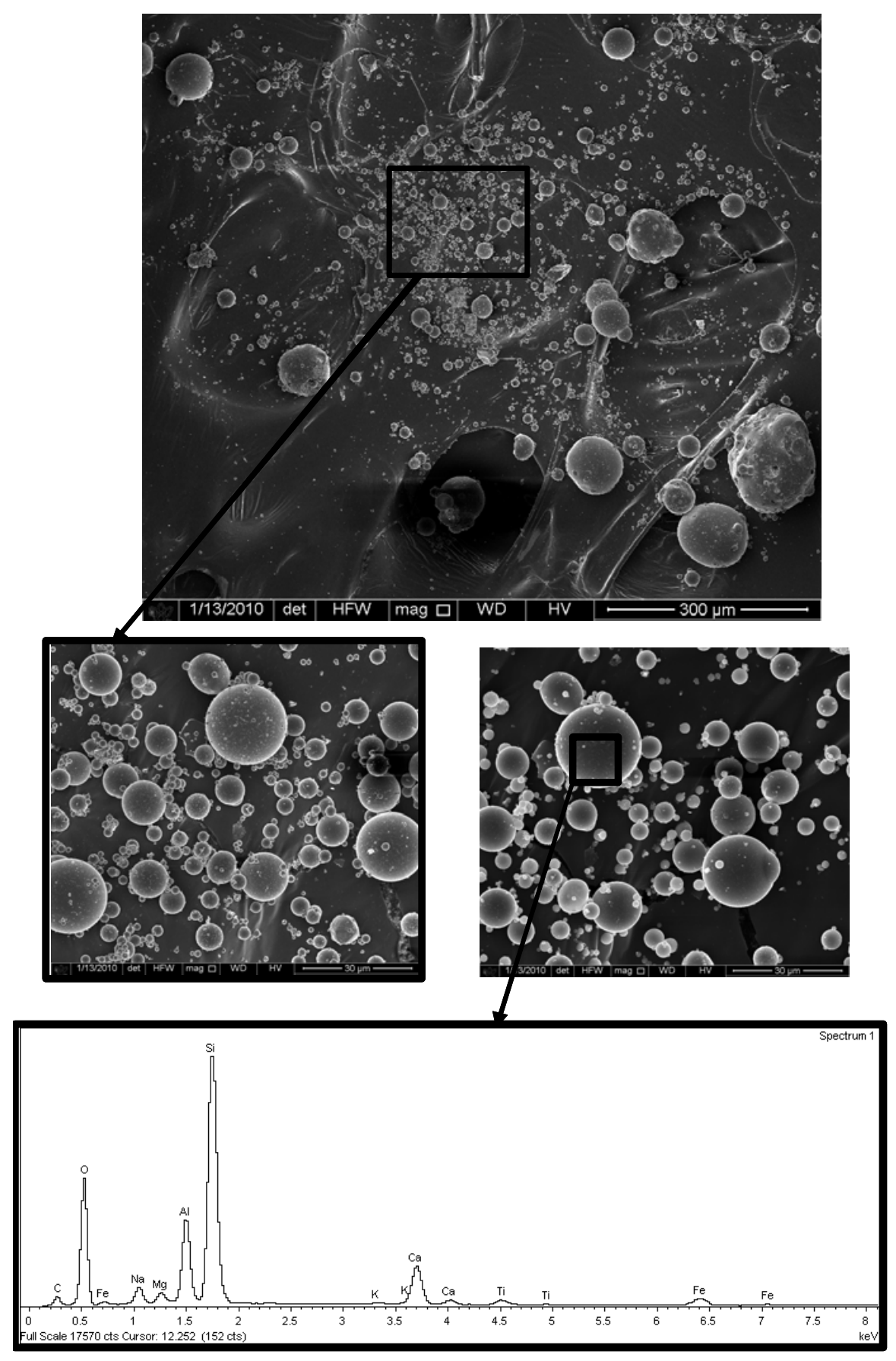

Figure 5.3. Fly Ash SEM Images and EDS Spectrum. The top image is a low-magnification $(\sim 300 \mu \mathrm{m})$ image of fly ash with an increased magnification of multiple spheres at $30 \mu \mathrm{m}$ (center left). The additional image (center right) was used to collect EDS spectra of a sphere of fly ash (bottom).

Figure 5.4 is a low-magnification micrograph that shows the morphologies, sizes, and surface textures of typical Portland cement particles. Analysis of the SEM micrographs indicates the aggregates of Portland cement are made up primarily of a single phase. The EDS spectrum reveals a high calcium and 
silicon content with minor amounts of aluminum, calcium, iron, magnesium, and sulfur. These results are consistent with the XRD identification (Figure 5.1c) and chemical digestion results (Table 5.1).

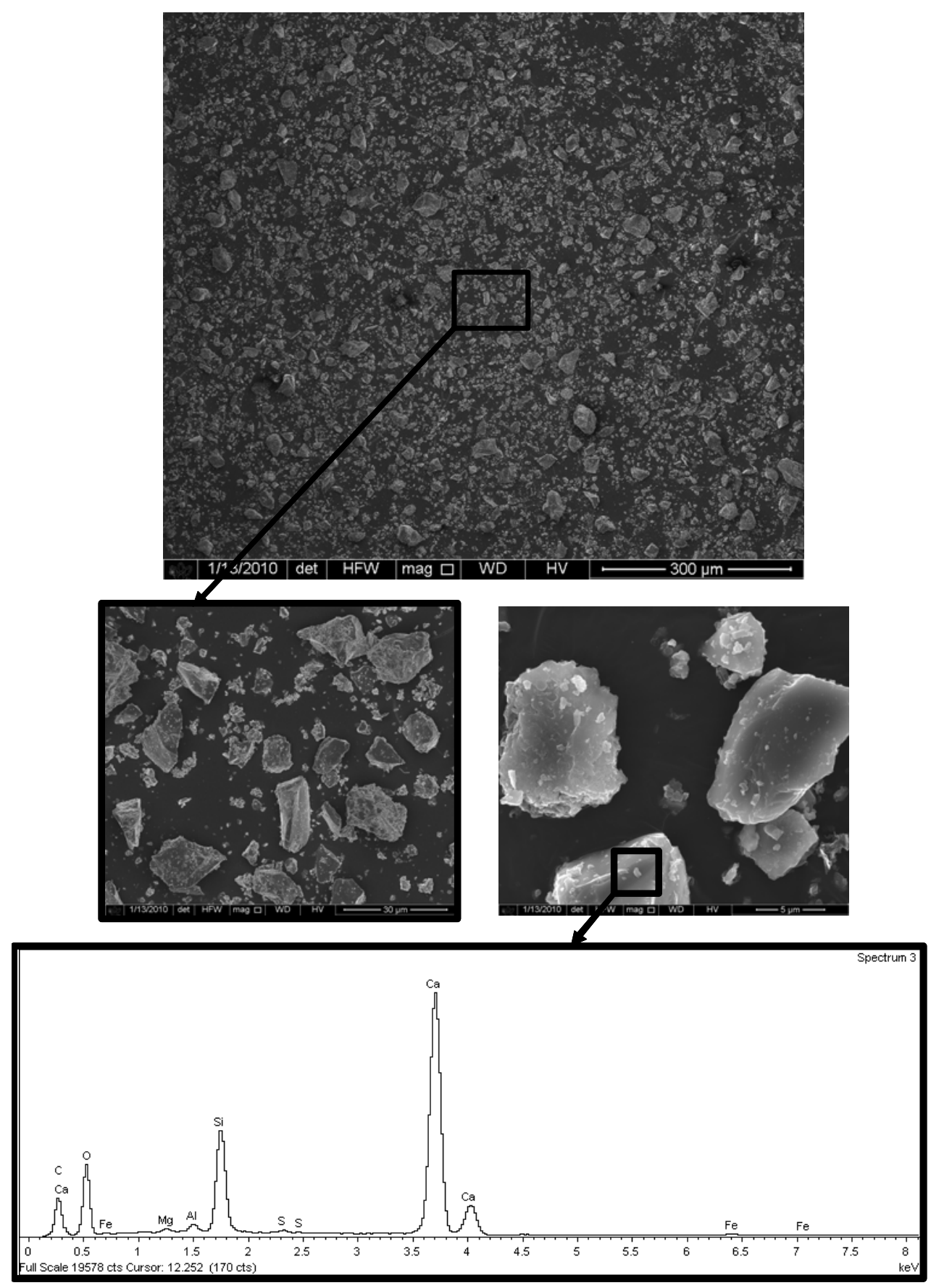

Figure 5.4. Portland Cement SEM Images and EDS Spectrum. The top image is a low-magnification $(\sim 300 \mu \mathrm{m})$ image of Portland cement with an increased magnification of multiple spheres at $30 \mu \mathrm{m}$ (center left). The additional image (center right) was used to collect EDS spectra of Portland cement (bottom). 
An image of a subsample of the 28-day cured Cast Stone is displayed in Figure 5.5. Analysis of this image shows the presence of partially reacted fly ash and BFS. In addition to these particles, several agglomerated particles, probably created by mixing the dry ingredients with liquid secondary waste simulant and DI water (see Section 3.1 for the Cast Stone preparation procedure), also are evident. Individual grains containing a large fraction of ${ }^{99} \mathrm{Tc}$, iodine, or other COC were not identified in these SEM/EDS samples.

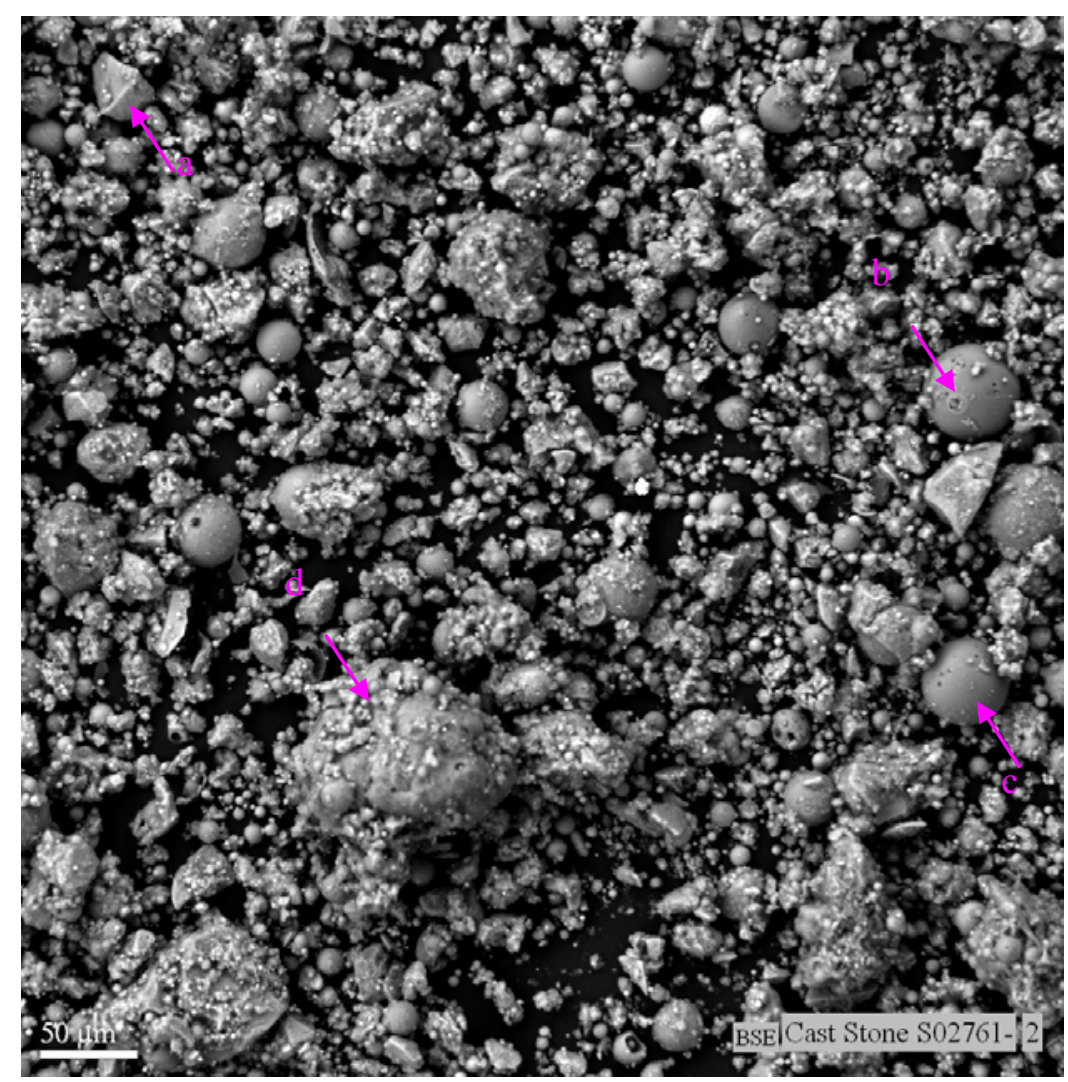

Figure 5.5. SEM Image of 28-Day Cured Cast Stone. The arrows point out individual particles of BFS (a) and fly ash (b and c, respectively). An arrow points to a large particle of cement (d) that appears to have formed from the dry materials reacting with the simulant.

\subsubsection{Geopolymer-Duralith Alkali Aluminosilicate}

The elemental composition of the raw materials used to prepare each batch of Geopolymer is shown in Table 5.2. The elemental concentration of arsenic, barium, potassium, molybdenum, sodium, silicon, and zirconium present in all five of the raw ingredients are comparable to one another. For example, the concentration of sodium ranges from $1.61 \times 10^{3}$ to $3.84 \times 10^{3} \mu \mathrm{g} / \mathrm{g}$, with the highest concentration being present in the Ag-zeolite. The concentration of phosphorus is comparable in fume silica, meta-kaolinite, and Ag-zeolite, but the concentration present in furnace slag and sand is significantly lower. The concentration of molybdenum, strontium, and titanium are comparable in four of the five raw ingredients, but these elements were not detected in Ag-zeolite, meta-kaolinite, or fumed silica, respectively. Lithium concentration was comparable in three of the five ingredients, but below the detection limit $(<8.0 \mu \mathrm{g} / \mathrm{g})$ in meta-kaolinite and Ag-zeolite. Antimony was detected in fumed silica and sand only and the values are 
comparable. Lead is only present in fumed silica and Ag-zeolite, and the values are comparable.

Beryllium also is only present in fumed silica and Ag-zeolite, but the values are not comparable. Cobalt, nickel, and uranium were only detected in meta-kaolinite, whereas copper was detected in two ingredients, fume silica and meta-kaolinite. For all the other elements (aluminum, calcium, chromium, iron, magnesium, manganese, sulfur, titanium, vanadium, and zinc), a larger variation in concentration exists among the individual ingredients. For example, the sulfur concentration in furnace slag $(1.07 \times$ $10^{4} \mu \mathrm{g} / \mathrm{g}$ ) is more than 200 times higher than in sand. In this section, the word "comparable" is used qualitatively and refers to situations where the elemental concentrations for each raw ingredient are within an order of magnitude of one another. The results in Table 5.2 also illustrate that a portion of the total amount of some RCRA metal contained in the Geopolymer originates from the raw materials. For example, approximately $46.8 \mathrm{wt} \%$ of cadmium originates from the simulant with the remaining amount coming from fume silica $(9.5 \mathrm{wt} \%)$, metakaolin $(16.7 \mathrm{wt} \%)$, furnace slag $(11.0 \mathrm{wt} \%)$, sand $(15.6 \mathrm{wt} \%)$, and Ag-zeolite (0.4 wt \%). Meta-kaolinite contributes approximately $76.8 \mathrm{wt} \%$ of the total chromium with the remaining amounts originating from the fume silica $(7.0 \mathrm{wt} \%)$, simulant $(8.6 \mathrm{wt} \%)$, sand $(6.4$ $\mathrm{wt} \%)$, furnace slag $(1.0 \mathrm{wt} \%)$, and Ag-zeolite $(0.1 \mathrm{wt} \%)$. The majority of lead comes from the simulant (49.7 wt $\%$ ) with smaller contributions from fumed silica (33.0 wt $\%)$, meta-kaolinite $(6.8 \mathrm{wt} \%)$, furnace slag (4.2 wt \%), sand (6.0 wt \%), and Ag-zeolite (0.3 wt \%). At this time, the samples prepared to determine the contribution of silver and mercury from the raw materials are being re-analyzed, and the results will be discussed in the final report.

Table 5.2. Chemical Composition, in $\mu \mathrm{g} / \mathrm{g}$, of a Portion of the Raw Materials-Fumed Silica, MetaKaolinite, Furnace Slag, Sand, and Ag-Zeolite-Used to Prepare the Geopolymer Samples(a)

\begin{tabular}{cccccc}
\hline $\begin{array}{c}\text { Elements } \\
(\mu \mathrm{g} / \mathrm{g})\end{array}$ & Fume Silica & Meta-Kaolinite & Furnace Slag & Sand & $\begin{array}{c}\text { Ag- } \\
\text { Zeolite }\end{array}$ \\
\hline $\mathrm{Al}$ & $2.10 \mathrm{E}+02$ & $3.67 \mathrm{E}+04$ & $1.16 \mathrm{E}+01$ & $3.34 \mathrm{E}+03$ & $6.47 \mathrm{E}+03$ \\
$\mathrm{Ag}$ & $\mathrm{NA}^{(\text {b) }}$ & NA & NA & NA & NA \\
$\mathrm{As}$ & $4.00 \mathrm{E}+01$ & $1.87 \mathrm{E}+01$ & $3.46 \mathrm{E}+01$ & $4.39 \mathrm{E}+01$ & $2.16 \mathrm{E}+01$ \\
$\mathrm{Ba}$ & $2.57 \mathrm{E}+01$ & $1.32 \mathrm{E}+01$ & $4.05 \mathrm{E}+01$ & $7.01 \mathrm{E}+01$ & $4.03 \mathrm{E}+00$ \\
$\mathrm{Be}$ & $4.89 \mathrm{E}-01$ & $<0.29$ & $<0.27$ & $<0.27$ & $5.09 \mathrm{E}+00$ \\
$\mathrm{Ca}$ & $5.24 \mathrm{E}+03$ & $<8.81$ & $8.61 \mathrm{E}+03$ & $1.64 \mathrm{E}+02$ & $2.78 \mathrm{E}+02$ \\
$\mathrm{Co}$ & $<1.73$ & $1.03 \mathrm{E}+01$ & $<1.71$ & $<1.71$ & $<1.81$ \\
$\mathrm{Cr}$ & $1.84 \mathrm{E}+01$ & $1.16 \mathrm{E}+02$ & $2.41 \mathrm{E}+00$ & $1.04 \mathrm{E}+01$ & $8.17 \mathrm{E}+00$ \\
$\mathrm{Cu}$ & $2.05 \mathrm{E}+01$ & $2.00 \mathrm{E}+01$ & $<2.28$ & $<2.28$ & $<2.43$ \\
$\mathrm{Fe}$ & $6.69 \mathrm{E}+02$ & $1.93 \mathrm{E}+03$ & $3.26 \mathrm{E}+02$ & $3.87 \mathrm{E}+03$ & $6.18 \mathrm{E}+03$ \\
$\mathrm{~K}$ & $4.58 \mathrm{E}+03$ & $1.08 \mathrm{E}+03$ & $2.83 \mathrm{E}+03$ & $1.97 \mathrm{E}+03$ & $4.86 \mathrm{E}+03$ \\
$\mathrm{Li}$ & $1.22 \mathrm{E}+01$ & $<7.89$ & $3.08 \mathrm{E}+01$ & $9.46 \mathrm{E}+00$ & $<7.89$ \\
$\mathrm{Mg}$ & $5.50 \mathrm{E}+02$ & $7.02 \mathrm{E}+00$ & $6.67 \mathrm{E}+02$ & $5.16 \mathrm{E}+01$ & $6.86 \mathrm{E}+00$ \\
$\mathrm{Mn}$ & $2.36 \mathrm{E}+02$ & $<0.76$ & $4.07 \mathrm{E}+03$ & $5.36 \mathrm{E}+01$ & $5.85 \mathrm{E}+02$ \\
$\mathrm{Mo}$ & $5.48 \mathrm{E}+00$ & $3.24 \mathrm{E}+00$ & $7.93 \mathrm{E}+00$ & $9.17 \mathrm{E}+00$ & $<2.88$ \\
$\mathrm{Na}$ & $1.89 \mathrm{E}+03$ & $1.61 \mathrm{E}+03$ & $1.98 \mathrm{E}+03$ & $1.50 \mathrm{E}+03$ & $3.84 \mathrm{E}+03$ \\
$\mathrm{Ni}$ & $<1.68$ & $1.04 \mathrm{E}+01$ & $<1.66$ & $<1.66$ & $<1.76$
\end{tabular}


Table 5.2. (contd)

\begin{tabular}{|c|c|c|c|c|c|}
\hline $\begin{array}{c}\text { Elements } \\
(\mu \mathrm{g} / \mathrm{g})\end{array}$ & Fume Silica & Meta-Kaolinite & Furnace Slag & Sand & $\begin{array}{c}\text { Ag- } \\
\text { Zeolite }\end{array}$ \\
\hline $\mathrm{P}$ & $3.96 \mathrm{E}+02$ & $8.94 \mathrm{E}+02$ & $<10.55$ & $5.36 \mathrm{E}+01$ & $2.97 \mathrm{E}+02$ \\
\hline $\mathrm{Pb}$ & $3.22 \mathrm{E}+01$ & $<3.80$ & $<3.57$ & $<3.57$ & $6.67 \mathrm{E}+00$ \\
\hline S & $7.82 \mathrm{E}+02$ & $2.05 \mathrm{E}+02$ & $1.07 \mathrm{E}+04$ & $4.50 \mathrm{E}+01$ & $4.87 \mathrm{E}+01$ \\
\hline $\mathrm{Sb}$ & $2.16 \mathrm{E}+01$ & $<8.43$ & $<7.93$ & $2.60 \mathrm{E}+01$ & $<8.43$ \\
\hline $\mathrm{Si}$ & $4.02 E+05$ & $2.48 \mathrm{E}+05$ & $1.84 \mathrm{E}+05$ & $4.26 \mathrm{E}+05$ & $2.90 \mathrm{E}+05$ \\
\hline $\mathrm{Sr}$ & $5.33 \mathrm{E}+01$ & $<0.55$ & $2.36 \mathrm{E}+02$ & $1.01 \mathrm{E}+01$ & $1.11 \mathrm{E}+01$ \\
\hline $\mathrm{Ti}$ & $3.02 \mathrm{E}+01$ & $1.09 \mathrm{E}+04$ & $2.97 \mathrm{E}+03$ & $2.43 \mathrm{E}+03$ & $7.29 \mathrm{E}+02$ \\
\hline $\mathrm{Tl}$ & $<11.61$ & $1.50 \mathrm{E}+02$ & $2.00 \mathrm{E}+01$ & $4.94 \mathrm{E}+01$ & $6.26 \mathrm{E}+01$ \\
\hline $\mathrm{U}$ & $<2.63$ & $2.61 \mathrm{E}+01$ & $<2.59$ & $<2.59$ & $<2.76$ \\
\hline V & $2.60 \mathrm{E}+00$ & $1.68 \mathrm{E}+02$ & $2.41 \mathrm{E}+01$ & $1.23 \mathrm{E}+01$ & $1.52 \mathrm{E}+01$ \\
\hline $\mathrm{Zn}$ & $7.67 \mathrm{E}+02$ & $3.03 \mathrm{E}+01$ & $1.36 \mathrm{E}+01$ & $1.15 \mathrm{E}+01$ & $1.51 \mathrm{E}+02$ \\
\hline $\mathrm{Zr}$ & $1.24 \mathrm{E}+01$ & $1.05 \mathrm{E}+02$ & $2.54 \mathrm{E}+01$ & $8.99 \mathrm{E}+01$ & $1.15 \mathrm{E}+02$ \\
\hline
\end{tabular}

(a) Elements below quantification limit $-\mathrm{Bi}<3.6, \mathrm{Cd}<0.5 \mu \mathrm{g} / \mathrm{g}, \mathrm{Re}<3.6 \mu \mathrm{g} / \mathrm{g}, \mathrm{Se}<20.5 \mu \mathrm{g} / \mathrm{g}$, and $\mathrm{Sn}<4.4 \mu \mathrm{g} / \mathrm{g}$.

(b) NA - not analyzed. At the time of this report Ag analysis was not complete

The chemical compositions for each of the 30-day cured Geopolymer samples are shown in Table 5.3. These results indicate that most of the elements for each batch are comparable except for silver, arsenic, mercury, tin, ${ }^{99} \mathrm{Tc}$, and vanadium. In the case of silver, arsenic, and ${ }^{99} \mathrm{Tc}$, the concentration of these elements are between 1.3 and 4.4 times higher in batch \#1 versus batch \#2. For mercury, tin, and vanadium, the concentration in batch $\# 2$ is $1.6,1.3$, and 6.7 times higher than in batch $\# 1$, respectively. In the case of vanadium, this suggests that either 1) slightly larger amounts of raw ingredients, possibly meta-kaolinite, may have been added to the mixture in the second batch in comparison to batch \#1 or 2) a larger proportion of the raw ingredients, possibly meta-kaolinite, reacted because of the way the mixture was prepared. The reason for presuming meta-kaolinite is because the majority of the vanadium contained in these samples originates from this ingredient. It appears that slightly more tin was added to the activator solution in batch \#2 than in batch \#1. The ingredient $\mathrm{SnCl}_{2}$ was added to the activator solution in an attempt to reduce $\mathrm{Tc}(\mathrm{VII})$ to $\mathrm{Tc}(\mathrm{IV})$ because $\mathrm{Tc}(\mathrm{IV})$ can precipitate as a reduced solid, $\mathrm{TcO}_{2}$, in the presence of a reducing agent such as tin. This process can increase the retention of ${ }^{99} \mathrm{Tc}$ in the Geopolymer samples.

Table 5.3. Chemical Composition, in $\mu \mathrm{g} / \mathrm{g}$, of 28-Day Cured Geopolymer Samples from Batch \#1 and Batch \#2

\begin{tabular}{ccc}
\hline $\begin{array}{c}\text { Elements } \\
(\mu \mathrm{g} / \mathrm{g})\end{array}$ & $\begin{array}{c}\text { Geopolymer } \\
\text { Batch \#1 }\end{array}$ & $\begin{array}{c}\text { Geopolymer } \\
\text { Batch \#2 }\end{array}$ \\
\hline $\mathrm{Tc}$ & $3.01 \mathrm{E}-01$ & $2.29 \mathrm{E}-01$ \\
$\mathrm{Al}$ & $6.76 \mathrm{E}+04$ & $6.74 \mathrm{E}+04$ \\
$\mathrm{Ag}$ & $1.01 \mathrm{E}+03$ & $7.85 \mathrm{E}+02$ \\
$\mathrm{As}$ & $4.63 \mathrm{E}+00$ & $1.06 \mathrm{E}+00$ \\
$\mathrm{Ba}$ & $2.07 \mathrm{E}+02$ & $1.93 \mathrm{E}+02$
\end{tabular}


Table 5.3. (contd)

\begin{tabular}{ccc}
\hline $\begin{array}{c}\text { Elements } \\
(\mu \mathrm{g} / \mathrm{g})\end{array}$ & $\begin{array}{c}\text { Geopolymer } \\
\text { Batch \#1 }\end{array}$ & $\begin{array}{c}\text { Geopolymer } \\
\text { Batch } \# 2\end{array}$ \\
\hline $\mathrm{B}$ & $7.83 \mathrm{E}+05$ & $7.81 \mathrm{E}+05$ \\
$\mathrm{Ca}$ & $5.35 \mathrm{E}+04$ & $5.08 \mathrm{E}+04$ \\
$\mathrm{Cd}$ & $1.76 \mathrm{E}+00$ & $1.84 \mathrm{E}+00$ \\
$\mathrm{Cr}$ & $2.59 \mathrm{E}+01$ & $2.85 \mathrm{E}+01$ \\
$\mathrm{Cu}$ & $3.05 \mathrm{E}+00$ & $3.36 \mathrm{E}+00$ \\
$\mathrm{Fe}$ & $2.34 \mathrm{E}+03$ & $2.33 \mathrm{E}+03$ \\
$\mathrm{Hg}$ & $1.90 \mathrm{E}+00$ & $3.01 \mathrm{E}+00$ \\
\hline $\mathrm{I}$ & $<4.97 \mathrm{E}-01$ & $<6.59 \mathrm{E}-01$ \\
$\mathrm{~K}$ & $8.43 \mathrm{E}+04$ & $7.91 \mathrm{E}+04$ \\
$\mathrm{Mg}$ & $1.13 \mathrm{E}+04$ & $1.12 \mathrm{E}+04$ \\
$\mathrm{Mn}$ & $7.29 \mathrm{E}+02$ & $7.34 \mathrm{E}+02$ \\
\hline $\mathrm{Na}$ & $1.92 \mathrm{E}+04$ & $1.80 \mathrm{E}+04$ \\
\hline $\mathrm{P}$ & $4.81 \mathrm{E}+02$ & $4.00 \mathrm{E}+02$ \\
$\mathrm{~Pb}$ & $5.43 \mathrm{E}+01$ & $5.06 \mathrm{E}+01$ \\
$\mathrm{~S}$ & $1.88 \mathrm{E}+03$ & $1.89 \mathrm{E}+03$ \\
$\mathrm{Si}$ & $2.53 \mathrm{E}+05$ & $2.45 \mathrm{E}+05$ \\
$\mathrm{Sn}$ & $8.19 \mathrm{E}+02$ & $1.03 \mathrm{E}+03$ \\
$\mathrm{Sr}$ & $2.11 \mathrm{E}+02$ & $1.96 \mathrm{E}+02$ \\
$\mathrm{Ti}$ & $4.08 \mathrm{E}+03$ & $4.00 \mathrm{E}+03$ \\
$\mathrm{~V}$ & $3.11 \mathrm{E}+00$ & $2.05 \mathrm{E}+01$ \\
$\mathrm{Zn}$ & $1.51 \mathrm{E}+02$ & $1.39 \mathrm{E}+02$ \\
$\mathrm{Zr}$ & $1.04 \mathrm{E}+02$ & $1.23 \mathrm{E}+02$ \\
\hline & &
\end{tabular}

Powder XRD measurements were performed on five raw ingredients used in the preparation of each Geopolymer sample. The five raw ingredients include fumed silica, meta-kaolinite, furnace slag, sand, and Ag-zeolite. The remaining materials used to prepare the Geopolymer were analytical grade chemicals. The XRD patterns are shown in Figure 5.6 along with the standard mineral PDF ${ }^{\mathrm{TM}}$. The fumed silica pattern (Figure 5.6a) illustrates that the majority of the material is amorphous, as evident by the broad diffraction pattern with the large peak centered near $21.3^{\circ} 2 \theta$, and contains minor amounts of crystalline impurities. The crystalline impurities were identified as quartz (PDF\#00-046-1045, $\mathrm{SiO}_{2}$ ), evident by the 100 percent peak near $26.7^{\circ} 2 \theta$, and silicon carbide (PDF\#04-002-9070, SiC), which has peaks at 35.7 and $60.1^{\circ} 2 \theta$. Similar to the fumed silica, meta-kaolinite and furnace slag (Figure $5.6 \mathrm{~b}$ and c, respectively) are also amorphous. The meta-kaolinite XRD pattern indicates a minor amount of crystalline impurities that have peaks near 8.8 and $25.3^{\circ} 2 \theta$, which were identified as halloysite-10A (PDF\# 00-029-1489, $\mathrm{Al}_{2} \mathrm{Si}_{2} \mathrm{O}_{5}(\mathrm{OH})_{4} \cdot 2 \mathrm{H}_{2} \mathrm{O}$ ) and anatase (PDF\# 01-086-1157, $\mathrm{Ti}_{0.72} \mathrm{O}_{2}$ ), respectively. The XRD patterns for sand and Ag-zeolite are shown in Figure 5.6d and e, respectively. A typical pattern for sand is shown in Figure 5.6d with the quartz (PDF\#00-046-1045, $\left.\mathrm{SiO}_{2}\right) 100$ percent distinguished peak near $26.7^{\circ} 2 \theta$. Minor amounts of an amorphous phase and two crystalline phases (tridymite 
[PDF\# 04-007-2509, $\mathrm{SiO}_{2}$ ] and silicon oxide [PDF\# 01-073-3464, $\mathrm{SiO}_{2}$ ], which have 100 percent peaks near 20.3 and $25.7^{\circ} 2 \theta$, respectively) were also identified. Although the dominant phase in the Ag-zeolite pattern is crystalline, it appears that a significant amount of amorphous material is also present (Figure 5.6e). The crystalline phases identified are mordenite (PDF\# 00-049-0924, $\mathrm{Na}_{2} \mathrm{Al}_{2} \mathrm{Si}_{13.3} \mathrm{O}_{29}$ ) with 100 percent peak at $25.8^{\circ} 2 \theta$ and Na-heulandite (PDF\# 01-089-6419,

$\left.\mathrm{Na}_{1.56} \mathrm{H}_{2.34} \mathrm{Al}_{1.32}\left[\mathrm{Al}_{7.86} \mathrm{Si}_{28.14} \mathrm{O}_{72}\right] \cdot \mathrm{H}_{2} \mathrm{O}_{28.56}\right)$ with 100 percent peak near $9.83{ }^{\circ} 2 \theta$. The presence of impurities in the raw material is expected because industrial-grade raw materials were used to prepare the samples of Geopolymer discussed in this report. Industrial grade materials would also be used in the final solidification process if Geopolymer was the selected candidate. The XRD pattern for a 30-day cured Geopolymer sample is shown (Figure 5.6f). Semi-quantitative analysis of the pattern suggests that $>70$ $\mathrm{wt} \%$ of the sample consists of an amorphous phase with $<26 \mathrm{wt} \%$ crystalline material present as quartz (PDF\#00-046-1045, $\mathrm{SiO}_{2}$ ).
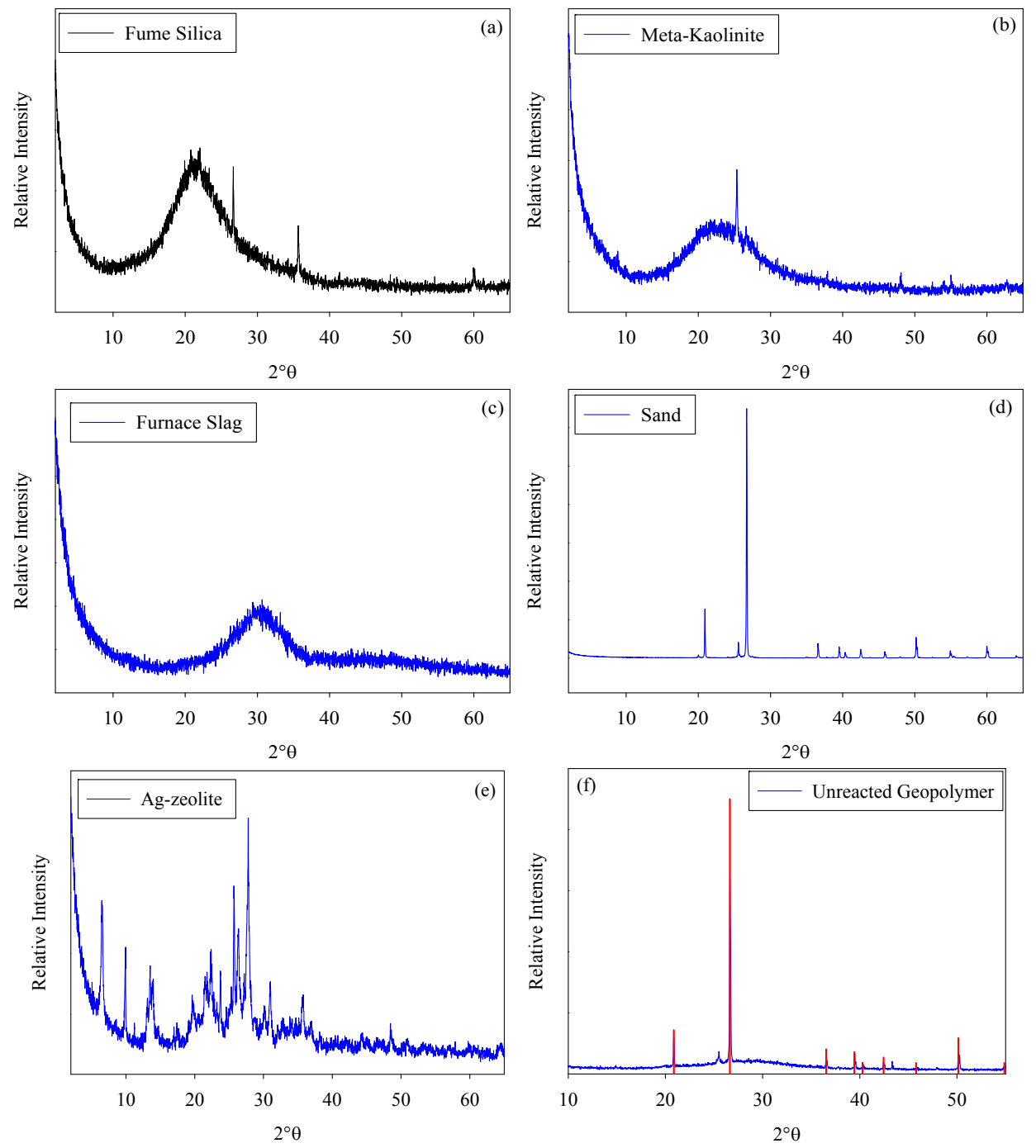

Figure 5.6. X-Ray Diffraction Spectra of Raw Material—Fume Silica (a), Meta-Kaolinite (b), Furnace Slag (c), Sand (d), and Ag-Zeolite (e) - and 30-Day Cured Geopolymer batch \#1 (f) 
SEM/EDS analyses of the raw materials and 30-day cured Geopolymer sample from batch \#1 are displayed in Figure 5.7 through Figure 5.13. The powdered subsample of 30-day cured Geopolymer from batch \#1 was taken from a monolith crushed for solids characterization and to be used in EPA Methods 1313 and 1316. Sample mount preparation and SEM/EDS analyses were completed as described in Section 4.3. Appendix E contains additional pre- and post-test SEM micrographs and the tabulations of the elemental compositions derived from the EDS analyses of the raw materials and Geopolymer samples.

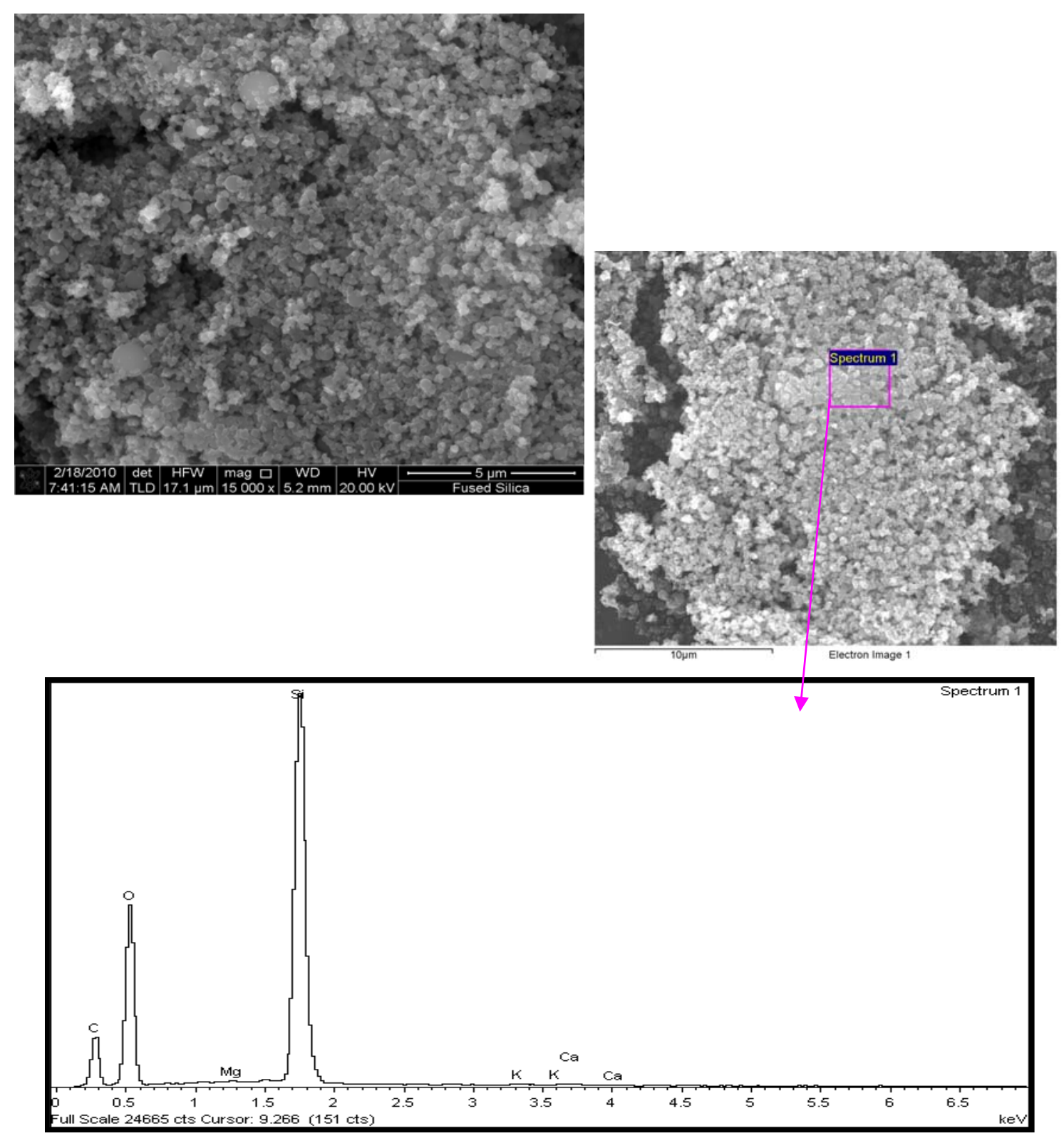

Figure 5.7. SEM Micrographs and EDS Spectrum of Fume Silica

Analysis of the SEM image of a fumed silica sample (Figure 5.7) shows numerous aggregated particles that have a spherical morphology. These small particles appear to have agglomerated together to form a large aggregate. The EDS spectrum reveals a high silicon and aluminum content for the spherical 
particles that contain a minor amount of calcium, potassium, and magnesium. Based upon the amorphous XRD pattern, chemical digestion, and SEM/EDS, one can conclude that these spherical particles are mainly an amorphous $\mathrm{SiO}_{2}$ phase.

Figure 5.8 shows the presence of a mixture of $10 \mu \mathrm{m}$ and less sized grains. Several of the $<10 \mu \mathrm{m}$ sized grains have a platy morphology, similar to a piece of lettuce, with sharp edges and are probably fragments of the larger meta-kaolinite particles. There are also several agglomerated $<10 \mu \mathrm{m}$ particles that have a tube-like morphology, which is a common morphology for halloysite. Consistent with the composition of meta-kaolinite, the EDS spectrum of the large particles reveals high amounts of aluminum and silicon with minor amounts of iron and titanium. Anatase particles were not positively identified in the SEM images of the meta-kaolinite sample.
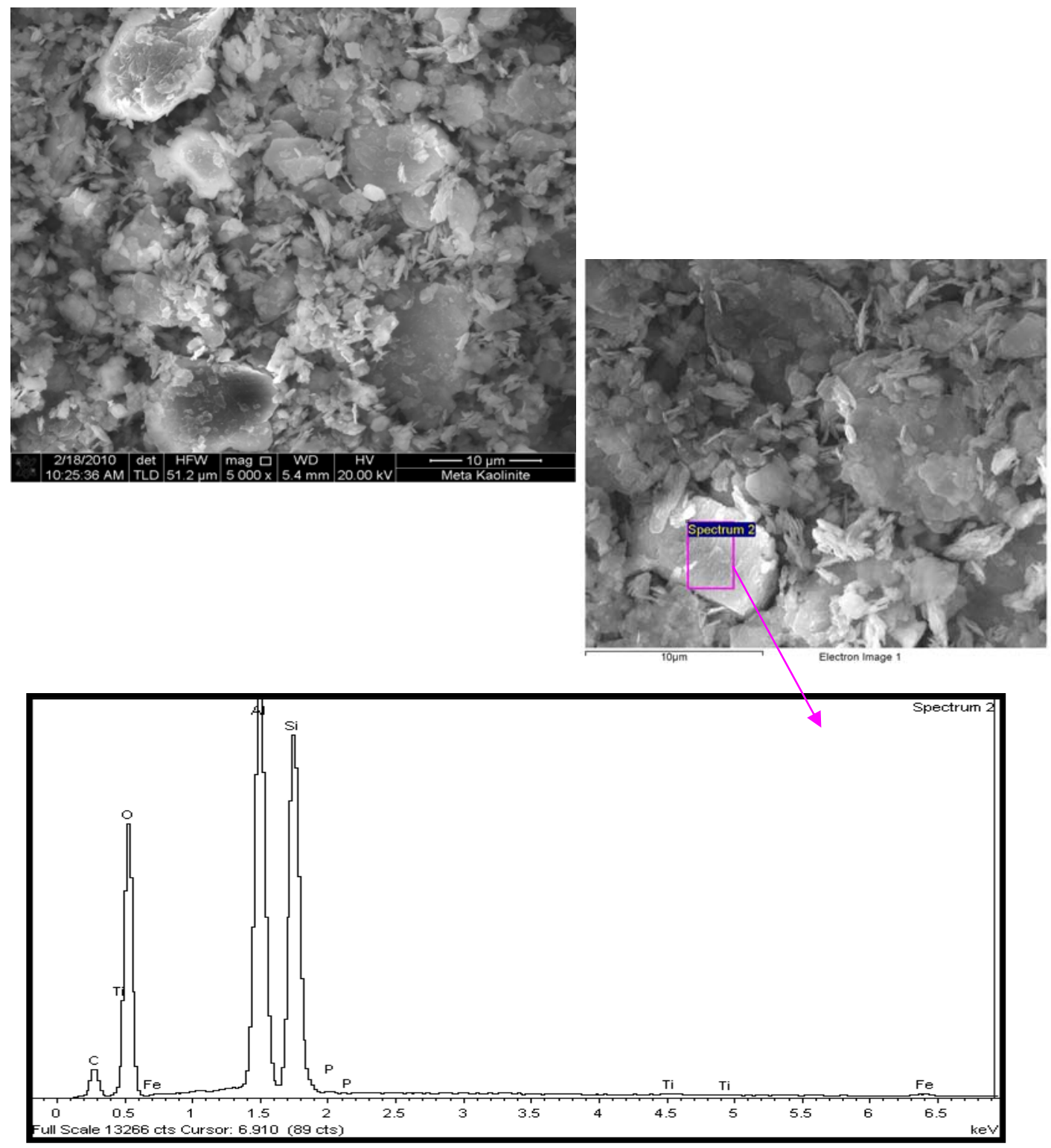

Figure 5.8. SEM Micrographs and EDS Spectrum of Meta-Kaolinite 
Although received from a different source, the furnace slag used to produce the Geopolymer samples is similar to the material used to produce Cast Stone. Analysis of the SEM micrograph (Figure 5.9) indicates that many of the particles are $10 \mu \mathrm{m}$ or less and vary considerably in their morphology, which is a result of the production process. The EDS spectrum reveals a high silicon and aluminum content for the spherical particles that contain a minor amount of calcium, iron, sodium, magnesium, and titanium. Based upon the amorphous XRD pattern, chemical digestion, and SEM/EDS, one can conclude these spherical particles are mainly an amorphous $\mathrm{SiO}_{2}$ phase that has become a host matrix for other cations and mineral phases.
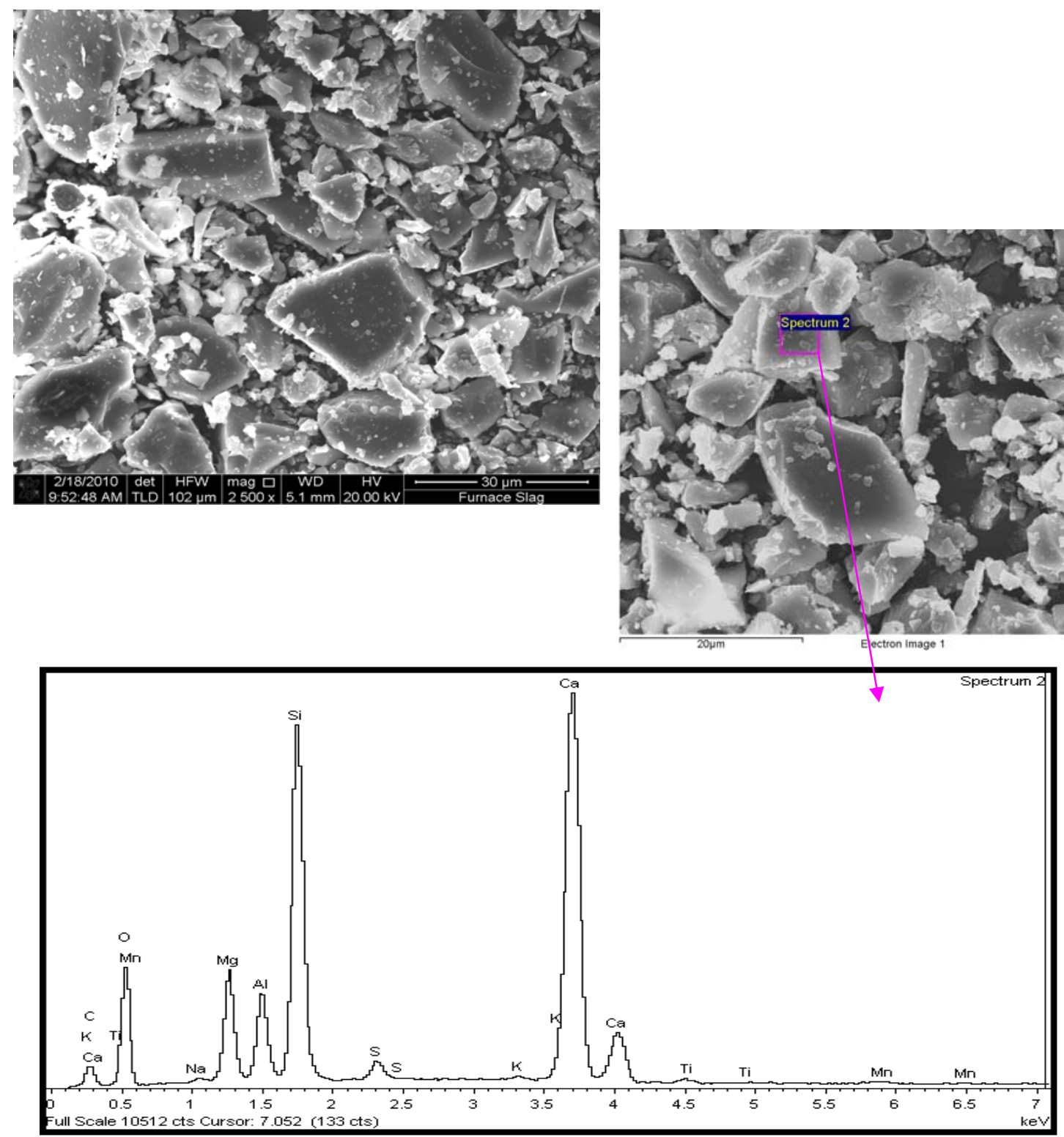

Figure 5.9. SEM Micrographs and EDS Spectrum of Furnace Slag. Composition similar to the furnace slag used to make Cast Stone 
The SEM image of silica sand is typical and consistent with the morphology of quartz (Figure 5.10). The EDS spectrum reveals a high silica content with a minor amount of aluminum, magnesium, potassium, and iron. The SEM micrograph of Ag-zeolite is a little more interesting (Figure 5.11). The image shows fairly large, irregular-shaped crystals that are consistent with the morphology of mordenite. The EDS spectrum reveals a high amount of silicon with minor amounts of silver, aluminum, calcium, iron, potassium, magnesium, and sodium.
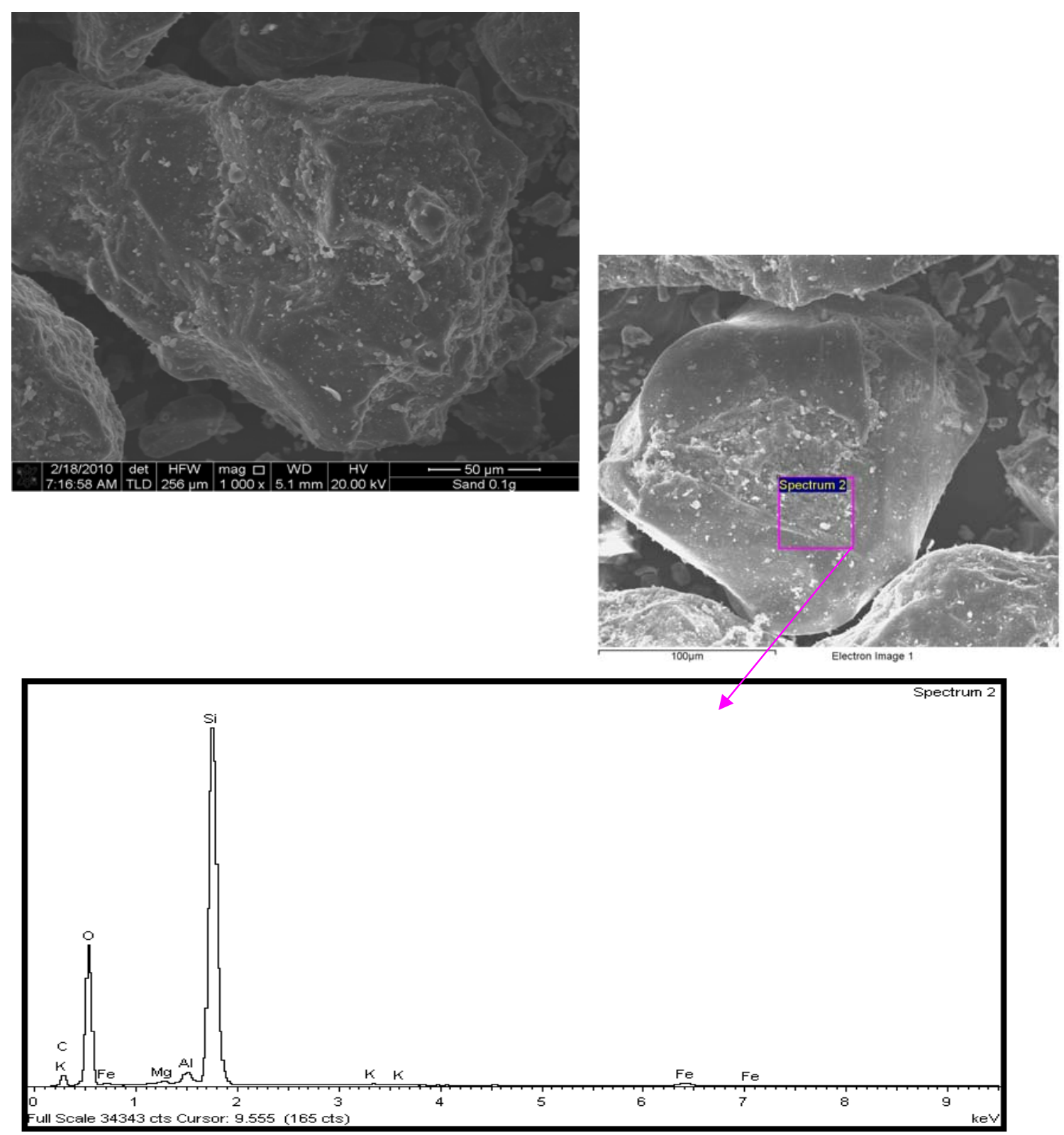

Figure 5.10. SEM Micrographs and EDS Spectrum of Sand 

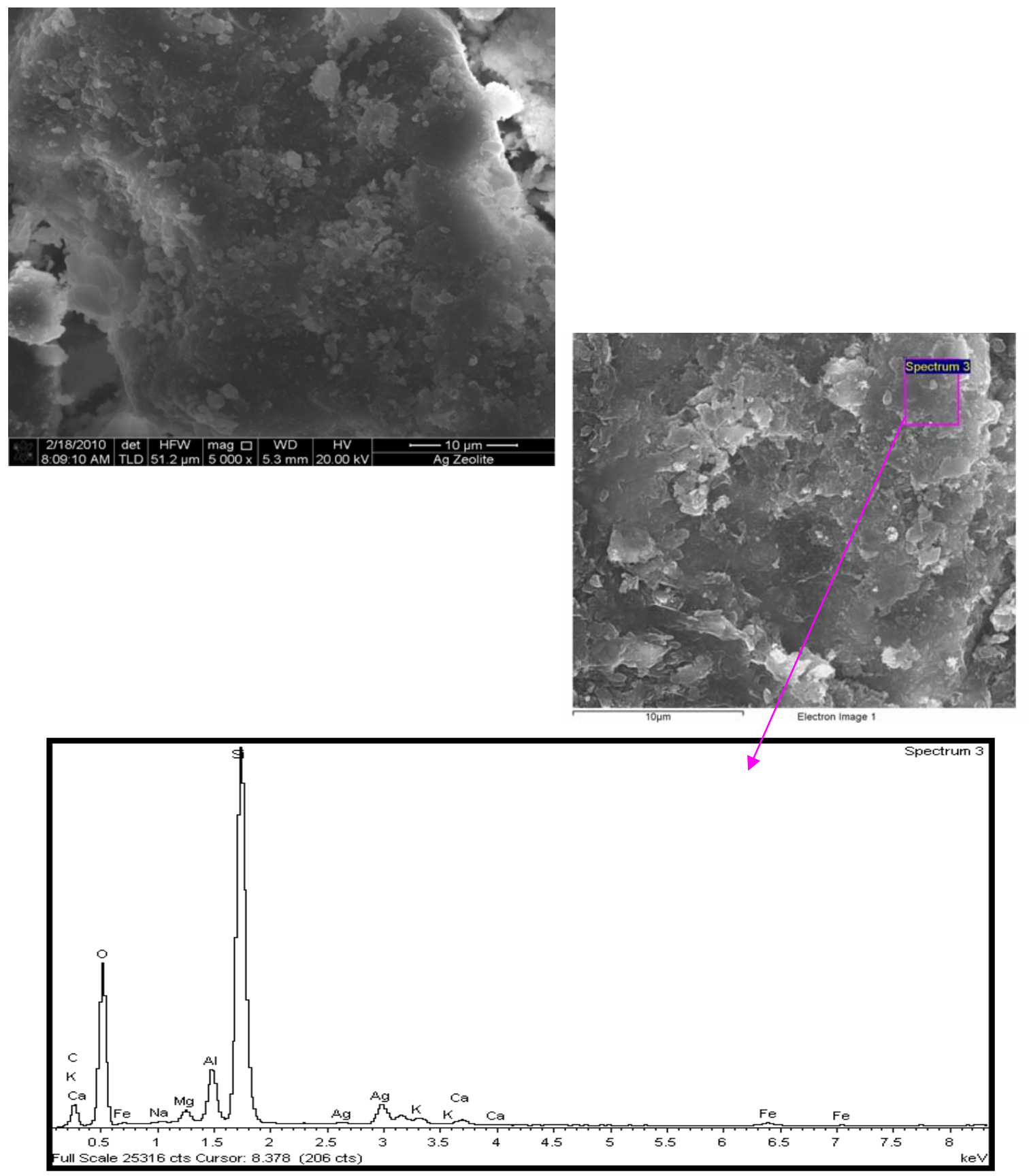

Figure 5.11. SEM Micrographs and EDS Spectrum of Ag-Zeolite

The SEM image of a subsample of 30-day cured Geopolymer is shown in Figure 5.12. This material was taken from an unreacted Geopolymer batch \#1 sample that was fractured and sized to $<0.3 \mathrm{~mm}$. Analysis of the image shows the presence of fine material with a few larger chunks of the sample. The EDS spectra of the larger particles (not shown here) suggest large amounts of aluminum, calcium, potassium, iron, silicon, and titanium with minor amounts of silver, copper, magnesium, and sulfur. 
Individual grains containing a large fraction of ${ }^{99} \mathrm{Tc}$, iodine, or other COC were not positively identified. Similar images were observed for unreacted Geopolymer batch \#2. See additional SEM/EDS data in Appendix E.

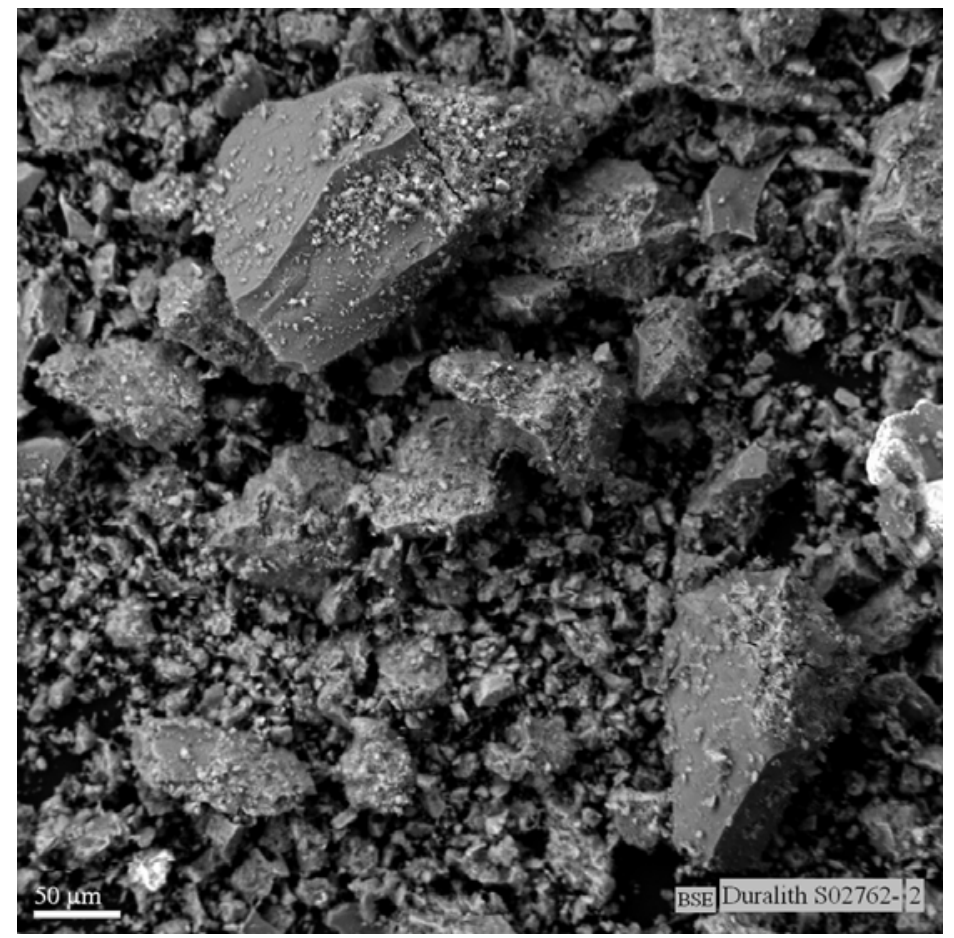

Figure 5.12. SEM Micrograph of an Unreacted Sample of 30-day Cured Geopolymer Batch \#1

\subsection{EPA Method 1313}

The results of the pre-titration and $\mathrm{pH}$ data for the leaching samples of Cast Stone and Geopolymer batch \#1 and batch \#2 with method 1313 are shown in Figure 5.13. Because of the high-alkaline solution $(\mathrm{pH}>12)$ that forms after equilibrating a subsample of Cast Stone or Geopolymer with DI water for 24 hours, all pre-titrations were performed only with acid. The pre-titrations were used to quantify the amount of acid required to maintain the equilibrating solution at a fixed target $\mathrm{pH}$, which ranged between 4 and 12. Based upon the pre-titration results, test samples were prepared mixing $10 \mathrm{~g}$ of $<0.3$-mm sized material with a predetermined amount of $2 \mathrm{~N} \mathrm{HNO}_{3}$ and bringing the samples to volume with DI water at $10 \mathrm{~mL} / \mathrm{g}$ ratio. These samples were allowed to react for 24 hours, and the resulting solutions were measured for $\mathrm{pH}, \mathrm{EC}$, Eh, and alkalinity (Table 5.4). 

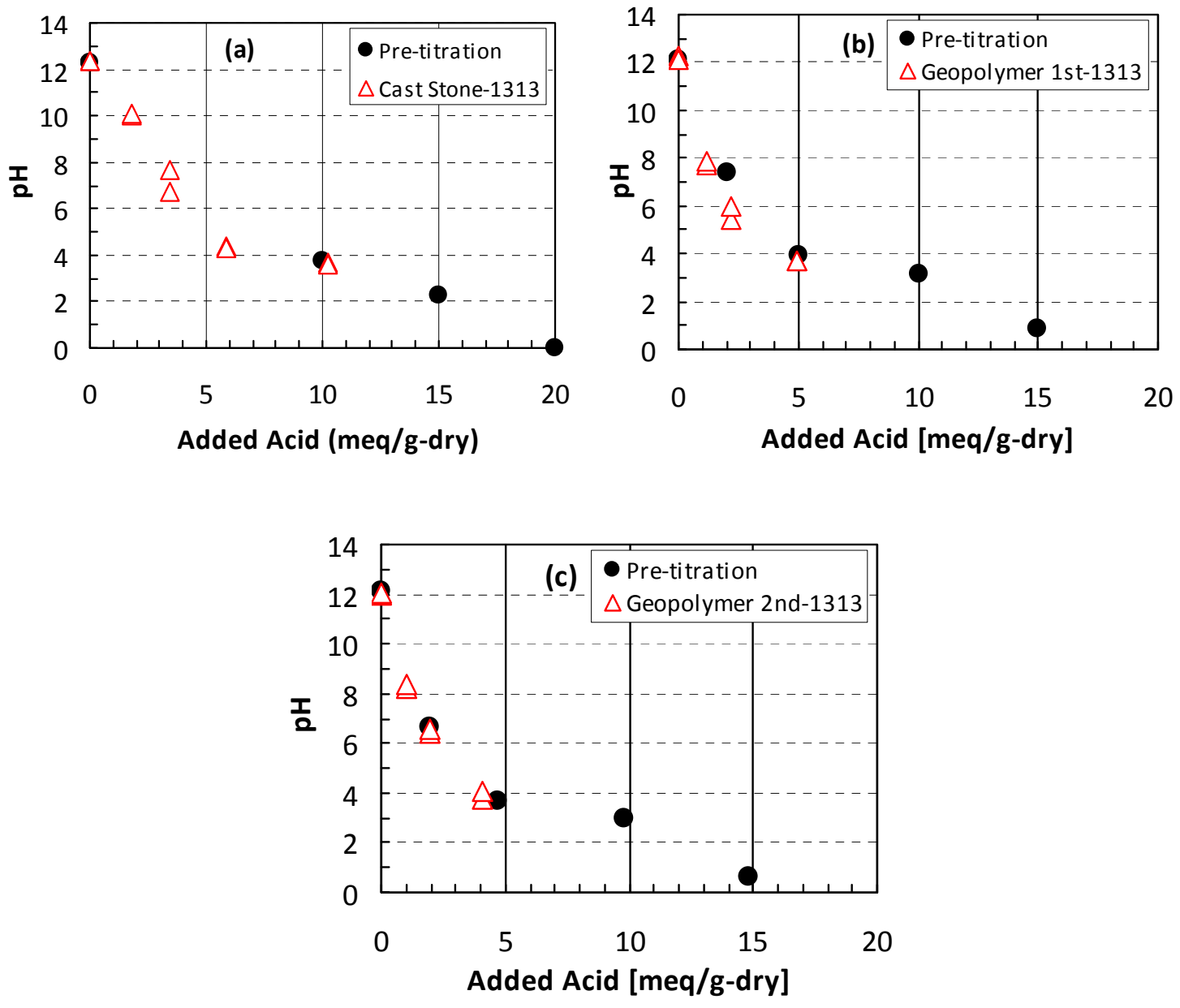

Figure 5.13. Titration Curves with Leaching Data for (a) Cast Stone; (b) Geopolymer Batch \#1; (c) Geopolymer Batch \#2

Table 5.4. The Values of $\mathrm{pH}, \mathrm{EC}$, Eh, and Alkalinity of Three Waste Forms Measured from the EPA Method 1313

\begin{tabular}{|c|c|c|c|c|}
\hline Waste Forms & $\mathrm{pH}$ & $\begin{array}{c}\mathrm{EC} \\
(\mathrm{mS} / \mathrm{cm})\end{array}$ & $\begin{array}{c}\mathrm{Eh} \\
(\mathrm{mV})\end{array}$ & $\begin{array}{c}\text { Alkalinity } \\
\left(\mathrm{mg} / \mathrm{L} \text { as } \mathrm{CaCO}_{3}\right)\end{array}$ \\
\hline \multirow{10}{*}{ Cast Stone } & 3.62 & 65.6 & 247 & 0.0 \\
\hline & 3.68 & 65.5 & 263 & 0.0 \\
\hline & 4.31 & 43.4 & 215 & 0.0 \\
\hline & 4.36 & 43.2 & 207 & 0.0 \\
\hline & 6.76 & 28.7 & 292 & 297 \\
\hline & 7.63 & 28.8 & 295 & 113 \\
\hline & 10.0 & 17.9 & 228 & 69.2 \\
\hline & 10.1 & 17.6 & 228 & 65.1 \\
\hline & 12.3 & 5.38 & 118 & 989 \\
\hline & 12.3 & 5.22 & 114 & 889 \\
\hline
\end{tabular}


Table 5.4. (contd)

\begin{tabular}{ccccc}
\hline Waste Forms & $\mathrm{pH}$ & $\begin{array}{c}\mathrm{EC} \\
(\mathrm{mS} / \mathrm{cm})\end{array}$ & $\begin{array}{c}\text { Eh } \\
(\mathrm{mV})\end{array}$ & $\begin{array}{c}\text { Alkalinity } \\
\left(\mathrm{mg} / \mathrm{L} \text { as } \mathrm{CaCO}_{3}\right)\end{array}$ \\
\hline & 3.66 & 43.5 & 364 & 0.0 \\
& 3.72 & 43.0 & 364 & 0.0 \\
Geopolymer & 5.42 & 24.0 & 313 & 32.1 \\
Batch \#1 & 5.94 & 23.8 & 306 & 67.6 \\
& 7.72 & 15.4 & 273 & 174 \\
& 7.85 & 15.5 & 273 & 174 \\
& 12.2 & 6.94 & 137 & 1248 \\
Geopolymer & 12.2 & 7.22 & 133 & 1302 \\
Batch \#2 & 3.79 & 38.1 & 251 & 0.0 \\
& 4.04 & 38.4 & 352 & 0.0 \\
& 6.41 & 21.7 & 301 & 129 \\
& 6.58 & 21.5 & 304 & 162 \\
& 8.25 & 13.9 & 270 & 204 \\
& 8.38 & 13.8 & 260 & 190 \\
& 12.0 & 6.25 & 138 & 1013 \\
\hline
\end{tabular}

Duplicate samples for all three waste forms showed consistent titration results. As expected, the alkalinity (as $\mathrm{mg} / \mathrm{L} \mathrm{CaCO}_{3}$ ) of the eluate solutions for each waste form decreased with decreasing $\mathrm{pH}$. For example, the Cast Stone alkalinity went from $\sim 900$ at $\mathrm{pH} 12.3$ to 0 at $\mathrm{pH} 3.3$. Conversely, the EC measurements showed lower dissolved salt content at high $\mathrm{pH}$, with the Geopolymer samples displaying a slightly narrower range in comparison to Cast Stone (Table 5.4). The measured EC values represent the concentration of dissolved ion (or salts) in solution, so the higher values observed at low $\mathrm{pH}$ are indicative of more dissolved ions present in solution. Measuring the Eh of a sample that is open to the atmosphere is difficult because atmospheric oxygen can diffuse into the sample and cause the Eh values to continuously change. To minimize the impact of oxygen diffusion in the sample, the Eh values reported in Table 5.4 were determined from the first stabilized Eh value taken within 10 seconds of the initial measurement. The measured Eh values for each waste form decreased with increasing $\mathrm{pH}$. In general, higher positive Eh values are indicative of relatively oxidizing conditions, and values below $+200 \mathrm{mV}$ to negative Eh values suggest reducing conditions. It is important to note that redox conditions are also highly influenced by $\mathrm{pH}$. Therefore, the two measurements should be used together to obtain an indication of the redox conditions of the system. For example, an examination of the Eh-pH diagrams for ${ }^{99} \mathrm{Tc}$ (shown in Figure 5.14) suggests that the stability range for a reduced form of ${ }^{99} \mathrm{Tc}$ can exist at low $\mathrm{pH}$ and under conditions with low but still positive Eh values. Based upon an examination of the Eh-pH diagram (Figure 5.14), the dominant ${ }^{99} \mathrm{Tc}$ species observed at high $\mathrm{pH}$ is the pertechnetate ion, $\mathrm{Tc}(\mathrm{VII}) \mathrm{O}_{4}{ }^{-}$ , which appears to still be dominant under alkaline and slightly reducing conditions (negative Eh values). 

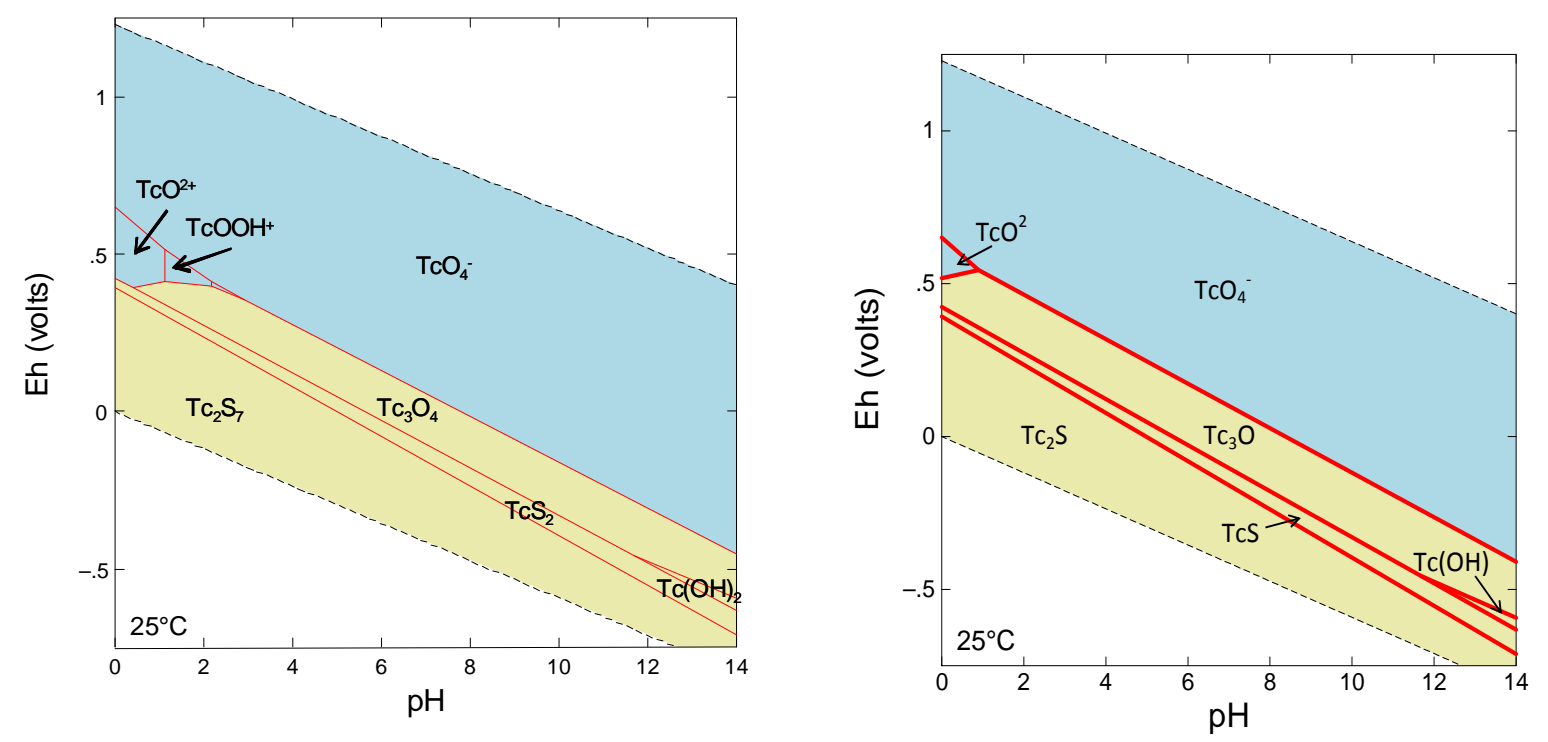

Figure 5.14. Eh-pH Stability Diagram for Dominant Technetium Species at $25^{\circ} \mathrm{C}$ for the Leachants Collected at 14 Days for Cast Stone Using Method 1315 (left). The concentrations of Tc and $\mathrm{SO}_{4}{ }^{2-}$ used for developing the diagram are $6.3 \times 10^{-11} \mathrm{M}(6.2 \mathrm{E}-3 \mu \mathrm{g} / \mathrm{L})$ and $2.4 \times 10^{-5} \mathrm{M}(2.3$ $\mathrm{mg} / \mathrm{L})$, respectively. The concentrations of other constituents used are found in Table 5.13 and 5.15 below. Eh-pH diagram for Tc developed with a slightly higher concentration $(5.1 \times$ $10^{-8} \mathrm{M}$ or $5.0 \mu \mathrm{g} / \mathrm{L}$ ) and the same concentrations of other constituents for comparison (right). Additional Eh-pH diagrams for other RCRA metals collected at 14 days for Cast Stone using Method 1315 are provided in Appendix F.

The measured concentration of ${ }^{99} \mathrm{Tc}$ in the leached solutions and the percent total leached technetium for the three waste forms are shown as a function of $\mathrm{pH}$ in Figure 5.15. In general, the concentration of ${ }^{99} \mathrm{Tc}$ in solution increased gradually with $\mathrm{pH}$ from 3.5 to 10 for all three waste forms. For Geopolymer batch \#1, the ${ }^{99} \mathrm{Tc}$ concentration continued to increase with $\mathrm{pH}$. For Geopolymer batch \#2 and Cast Stone, the concentration decreases at $\mathrm{pH}$ values $>10$. In all cases, Cast Stone demonstrated lower or equivalent release of ${ }^{99} \mathrm{Tc}$ in comparison to both Geopolymer batches tested. Based on these results (Figure 5.15), the $\mathrm{pH}$ range from 3 to 10 indicates Geopolymer batch \#1 had the highest release, Geopolymer batch \#2 had the second highest release, and Cast Stone had the lowest release. Currently, it is unclear why Geopolymer batch \#2 shows lower ${ }^{99} \mathrm{Tc}$ release in comparison to Geopolymer batch \#1, but it may be the result of the slight deviation in the preparation process (see Section 3.1). Finally, in the range of $\mathrm{pH} 4$ to 12 , the leached Tc (\%) showed 5 percent to 30 percent for Cast Stone, 17 percent to 31 percent for Geopolymer batch \#1, and 12 percent to 20 percent for Geopolymer batch \#2. It is important to note these experiments were conducted using a crushed sample of Cast Stone and Geopolymer batches \#1 and \#2 at a fixed solid-to-solution ratio. By using $<0.30$-mm sized material, the percent leached are expected to be high in comparison to the monolith samples of the same material.

The measured concentrations of major cations, RCRA metals, and anions are shown in Table 5.5 through Table 5.7. The concentration of the major cations and anions in solution increased with deceasing $\mathrm{pH}$, which is consistent with $\mathrm{EC}$ measurements. 

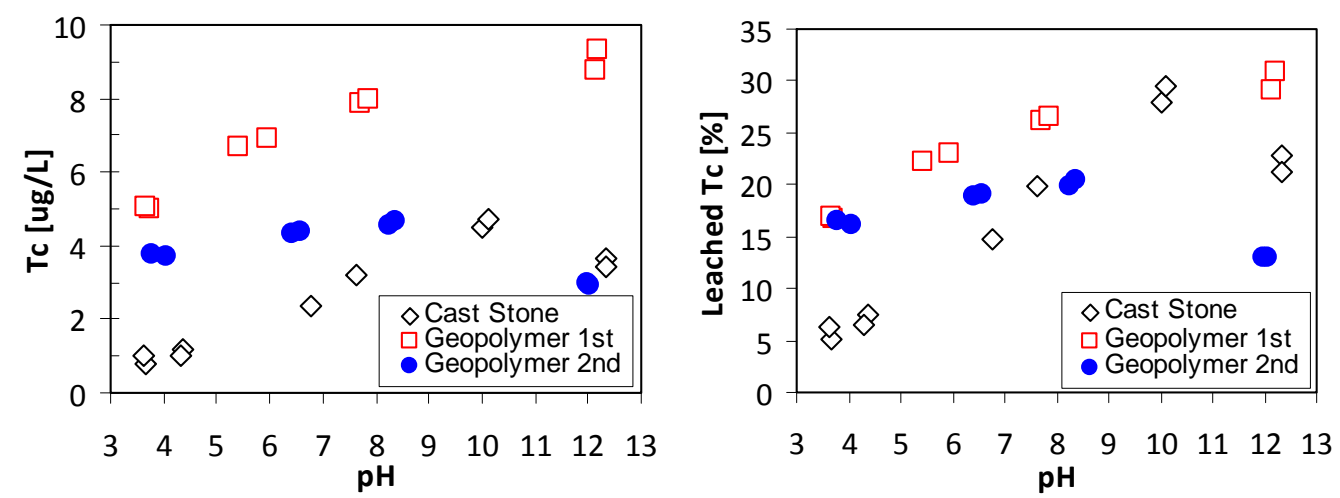

Figure 5.15. Leached Tc of Three Waste Forms in Method 1313. Tc concentration in eluate (left) and leached Tc (\%) based on total Tc concentration on each waste form (right)

For example, the calcium concentration measured for the Cast Stone samples at low $\mathrm{pH}(\mathrm{pH}<4, \mathrm{Ca}=$ $\left.1.4 \times 10^{4} \mathrm{mg} / \mathrm{L}\right)$ was significantly higher than the value measured at high $\mathrm{pH}\left(\mathrm{pH}>12, \mathrm{Ca}=4.0 \times 10^{1}\right.$ $\mathrm{mg} / \mathrm{L}$ ). The observed change in the calcium concentration may be associated with the formation of calcite $\left(\mathrm{CaCO}_{3}\right)$ at this high $\mathrm{pH}(>12)$. Although some RCRA metals (chromium, mercury, silver, and arsenic) are detected in eluates, detectable concentrations of lead, copper, and cadmium were not found in any of the three waste forms. In the case of silver - which was added to the Geopolymer batch \#1 and \#2 samples - the solubility of AgI is not controlling Ag release, evident by the low concentration of iodide in the leachates, suggesting iodide concentration is limiting the formation of AgI based upon thermodynamic considerations. The total sulfur concentration measured by ICP-OES was also converted to $\mathrm{SO}_{4}{ }^{2-}$ concentration and is listed in Table 5.7. Dominant cations in solution were sodium, calcium, and potassium, while $\mathrm{NO}_{3}{ }^{-}$(added for $\mathrm{pH}$ equilibration) and $\mathrm{CO}_{3}{ }^{2-}$ (from alkalinity) are dominant anions measured in the solution samples. Because calculated $\mathrm{SO}_{4}{ }^{2-}$ concentration from ICP-OES measurements represents total sulfur, the value listed in Table 5.7 was higher than the $\mathrm{SO}_{4}{ }^{2-}$ value measured by IC. The difference in the two $\mathrm{SO}_{4}{ }^{2-}$ values is probably associated with the presence of other sulfur species in solution, such as $\mathrm{S}^{2-}$ and $\mathrm{HS}^{-}$. Phosphate was not detected in most solutions. Leached ${ }^{127} \mathrm{I}$ was also measured and slightly higher iodide leaching was found in the Geopolymer samples than Cast Stone.

Table 5.5. The Concentrations of Major Cations in Eluate for Waste Forms from 1313 Method

\begin{tabular}{|c|c|c|c|c|c|c|c|c|c|}
\hline Waste Forms & $\mathrm{pH}$ & $\begin{array}{c}\mathrm{Na} \\
(\mathrm{mg} / \mathrm{L})\end{array}$ & $\begin{array}{c}\mathrm{Ca} \\
(\mathrm{mg} / \mathrm{L})\end{array}$ & $\begin{array}{c}\mathrm{K} \\
(\mathrm{mg} / \mathrm{L})\end{array}$ & $\begin{array}{c}\mathrm{Al} \\
(\mathrm{mg} / \mathrm{L})\end{array}$ & $\begin{array}{c}\mathrm{Si} \\
(\mathrm{mg} / \mathrm{L})\end{array}$ & $\begin{array}{c}\mathrm{Mg} \\
(\mathrm{mg} / \mathrm{L})\end{array}$ & $\begin{array}{c}\mathrm{S} \\
(\mathrm{mg} / \mathrm{L})\end{array}$ & $\begin{array}{c}\mathrm{Fe} \\
(\mathrm{mg} / \mathrm{L})\end{array}$ \\
\hline \multirow{4}{*}{ Cast Stone } & 3.62 & $\begin{array}{l}8.0 \mathrm{E}+2 \\
{[0.39]^{(\mathrm{a})}}\end{array}$ & $\begin{array}{l}1.7 \mathrm{E}+4 \\
{[1.44]}\end{array}$ & $\begin{array}{l}1.3 \mathrm{E}+2 \\
{[0.34]}\end{array}$ & $\begin{array}{l}7.8 \mathrm{E}+2 \\
{[0.30]}\end{array}$ & $\begin{array}{l}1.1 \mathrm{E}+2 \\
{[0.01]}\end{array}$ & $\begin{array}{l}1.1 \mathrm{E}+3 \\
{[0.96]}\end{array}$ & $\begin{array}{l}5.2 \mathrm{E}+2 \\
{[0.79]}\end{array}$ & $\begin{array}{l}3.9 \mathrm{E}+2 \\
{[0.18]}\end{array}$ \\
\hline & 3.68 & $\begin{array}{l}7.7 \mathrm{E}+2 \\
{[0.38]}\end{array}$ & $\begin{array}{l}1.7 \mathrm{E}+4 \\
{[1.44]}\end{array}$ & $\begin{array}{l}1.2 \mathrm{E}+2 \\
{[0.31]}\end{array}$ & $\begin{array}{l}7.4 \mathrm{E}+2 \\
{[0.28]}\end{array}$ & $\begin{array}{l}1.0 \mathrm{E}+2 \\
{[0.01]}\end{array}$ & $\begin{array}{l}1.1 \mathrm{E}+3 \\
{[0.96]}\end{array}$ & $\begin{array}{l}5.0 \mathrm{E}+2 \\
{[0.76]}\end{array}$ & $\begin{array}{l}3.7 \mathrm{E}+2 \\
{[0.17]}\end{array}$ \\
\hline & 4.31 & $\begin{array}{l}7.2 \mathrm{E}+2 \\
{[0.35]}\end{array}$ & $\begin{array}{l}1.0 \mathrm{E}+4 \\
{[0.85]}\end{array}$ & $\begin{array}{l}6.9 \mathrm{E}+1 \\
{[0.18]}\end{array}$ & $\begin{array}{l}1.3 \mathrm{E}+1 \\
{[0.00]}\end{array}$ & $\begin{array}{l}1.5 \mathrm{E}+2 \\
{[0.01]}\end{array}$ & $\begin{array}{l}5.5 E+2 \\
{[0.48]}\end{array}$ & $\begin{array}{l}6.5 \mathrm{E}+2 \\
{[0.98]}\end{array}$ & $\begin{array}{l}1.1 \mathrm{E}+2 \\
{[0.05]}\end{array}$ \\
\hline & 4.36 & $\begin{array}{l}6.8 \mathrm{E}+2 \\
{[0.33]}\end{array}$ & $\begin{array}{c}1.1 \mathrm{E}+4 \\
{[0.93]}\end{array}$ & $\begin{array}{l}6.8 \mathrm{E}+1 \\
{[0.18]}\end{array}$ & $\begin{array}{l}3.0 \mathrm{E}+1 \\
{[0.01]}\end{array}$ & $\begin{array}{l}1.6 \mathrm{E}+2 \\
{[0.01]}\end{array}$ & $\begin{array}{c}5.2 \mathrm{E}+2 \\
{[0.45]}\end{array}$ & $\begin{array}{l}6.3 \mathrm{E}+2 \\
{[0.95]}\end{array}$ & $\begin{array}{l}1.1 \mathrm{E}+2 \\
{[0.05]}\end{array}$ \\
\hline
\end{tabular}


Table 5.5. (contd)

\begin{tabular}{|c|c|c|c|c|c|c|c|c|c|}
\hline Waste Forms & $\mathrm{pH}$ & $\begin{array}{c}\mathrm{Na} \\
(\mathrm{mg} / \mathrm{L})\end{array}$ & $\begin{array}{c}\mathrm{Ca} \\
(\mathrm{mg} / \mathrm{L})\end{array}$ & $\begin{array}{c}\mathrm{K} \\
(\mathrm{mg} / \mathrm{L})\end{array}$ & $\begin{array}{c}\mathrm{Al} \\
(\mathrm{mg} / \mathrm{L})\end{array}$ & $\begin{array}{c}\mathrm{Si} \\
(\mathrm{mg} / \mathrm{L})\end{array}$ & $\begin{array}{c}\mathrm{Mg} \\
(\mathrm{mg} / \mathrm{L})\end{array}$ & $\begin{array}{c}\mathrm{S} \\
(\mathrm{mg} / \mathrm{L})\end{array}$ & $\begin{array}{c}\mathrm{Fe} \\
(\mathrm{mg} / \mathrm{L})\end{array}$ \\
\hline & 6.76 & $\begin{array}{l}6.5 \mathrm{E}+2 \\
{[0.32]}\end{array}$ & $\begin{array}{l}6.6 \mathrm{E}+3 \\
{[0.56]}\end{array}$ & $\begin{array}{l}4.9 \mathrm{E}+1 \\
{[0.13]}\end{array}$ & $\begin{array}{l}\mathrm{ND}^{(\mathbf{b})} \\
{[0.00]}\end{array}$ & $\begin{array}{l}2.1 \mathrm{E}+1 \\
{[0.00]}\end{array}$ & $\begin{array}{c}2.3 \mathrm{E}+2 \\
{[0.20]}\end{array}$ & $\begin{array}{l}5.3 \mathrm{E}+2 \\
{[0.80]}\end{array}$ & $\begin{array}{l}1.2 \mathrm{E}+0 \\
{[0.00]}\end{array}$ \\
\hline & 7.63 & $\begin{array}{l}6.4 \mathrm{E}+2 \\
{[0.32]}\end{array}$ & $\begin{array}{l}6.5 \mathrm{E}+3 \\
{[0.55]}\end{array}$ & $\begin{array}{l}4.8 \mathrm{E}+1 \\
{[0.13]}\end{array}$ & $\begin{array}{l}\mathrm{ND} \\
{[0.00]}\end{array}$ & $\begin{array}{l}8.9 \mathrm{E}+0 \\
{[0.00]}\end{array}$ & $\begin{array}{c}2.1 \mathrm{E}+2 \\
{[0.18]}\end{array}$ & $\begin{array}{l}5.4 \mathrm{E}+2 \\
{[0.82]}\end{array}$ & $\begin{array}{l}\mathrm{ND} \\
{[0.00]}\end{array}$ \\
\hline & 10.0 & $\begin{array}{l}6.3 \mathrm{E}+2 \\
{[0.31]}\end{array}$ & $\begin{array}{l}3.2 \mathrm{E}+3 \\
{[0.27]}\end{array}$ & $\begin{array}{l}4.9 \mathrm{E}+1 \\
{[0.13]}\end{array}$ & $\begin{array}{l}\mathrm{ND} \\
{[0.00]}\end{array}$ & $\begin{array}{l}5.5 \mathrm{E}+0 \\
{[0.00]}\end{array}$ & $\begin{array}{c}2.8 \mathrm{E}+1 \\
{[0.02]}\end{array}$ & $\begin{array}{l}3.2 \mathrm{E}+2 \\
{[0.48]}\end{array}$ & $\begin{array}{l}\mathrm{ND} \\
{[0.00]}\end{array}$ \\
\hline & 10.1 & $\begin{array}{l}6.6 \mathrm{E}+2 \\
{[0.33]}\end{array}$ & $\begin{array}{l}3.3 \mathrm{E}+3 \\
{[0.28]}\end{array}$ & $\begin{array}{l}5.1 \mathrm{E}+1 \\
{[0.13]}\end{array}$ & $\begin{array}{l}\mathrm{ND} \\
{[0.00]}\end{array}$ & $\begin{array}{l}5.5 \mathrm{E}+0 \\
{[0.00]}\end{array}$ & $\begin{array}{c}2.9 \mathrm{E}+1 \\
{[0.03]}\end{array}$ & $\begin{array}{l}3.2 \mathrm{E}+2 \\
{[0.48]}\end{array}$ & $\begin{array}{l}\mathrm{ND} \\
{[0.00]}\end{array}$ \\
\hline & 12.3 & $\begin{array}{l}5.3 \mathrm{E}+2 \\
{[0.26]}\end{array}$ & $\begin{array}{l}3.4 \mathrm{E}+1 \\
{[0.00]}\end{array}$ & $\begin{array}{l}4.7 \mathrm{E}+1 \\
{[0.12]}\end{array}$ & $\begin{array}{l}1.7 \mathrm{E}+1 \\
{[0.01]}\end{array}$ & $\begin{array}{l}1.3 \mathrm{E}+1 \\
{[0.00]}\end{array}$ & $\begin{array}{l}4.3 \mathrm{E}-2 \\
{[0.00]}\end{array}$ & $\begin{array}{l}1.2 \mathrm{E}+2 \\
{[0.18]}\end{array}$ & $\begin{array}{l}1.0 \mathrm{E}-1 \\
{[0.00]}\end{array}$ \\
\hline & 12.3 & $\begin{array}{l}5.3 \mathrm{E}+2 \\
{[0.26]}\end{array}$ & $\begin{array}{l}4.0 \mathrm{E}+1 \\
{[0.00]}\end{array}$ & $\begin{array}{l}4.4 \mathrm{E}+1 \\
{[0.11]}\end{array}$ & $\begin{array}{l}1.6 \mathrm{E}+1 \\
{[0.01]}\end{array}$ & $\begin{array}{l}1.1 \mathrm{E}+1 \\
{[0.00]}\end{array}$ & $\begin{array}{l}5.1 \mathrm{E}-4 \\
{[0.00]}\end{array}$ & $\begin{array}{l}1.2 \mathrm{E}+2 \\
{[0.18]}\end{array}$ & $\begin{array}{l}1.0 \mathrm{E}-1 \\
{[0.00]}\end{array}$ \\
\hline \multirow{8}{*}{$\begin{array}{l}\text { Geopolymer } \\
\text { Batch \#1 }\end{array}$} & 3.66 & $\begin{array}{l}1.7 \mathrm{E}+3 \\
{[0.89]}\end{array}$ & $\begin{array}{l}3.0 \mathrm{E}+3 \\
{[0.56]}\end{array}$ & $\begin{array}{l}5.9 \mathrm{E}+3 \\
{[0.70]}\end{array}$ & $\begin{array}{l}8.8 \mathrm{E}+2 \\
{[0.13]}\end{array}$ & $\begin{array}{l}2.3 \mathrm{E}+2 \\
{[0.01]}\end{array}$ & $\begin{array}{l}6.0 \mathrm{E}+2 \\
{[0.53]}\end{array}$ & $\begin{array}{l}1.6 \mathrm{E}+2 \\
{[0.85]}\end{array}$ & $\begin{array}{l}2.8 \mathrm{E}+1 \\
{[0.12]}\end{array}$ \\
\hline & 3.72 & $\begin{array}{l}1.6 \mathrm{E}+3 \\
{[0.83]}\end{array}$ & $\begin{array}{l}3.1 \mathrm{E}+3 \\
{[0.58]}\end{array}$ & $\begin{array}{l}5.6 \mathrm{E}+3 \\
{[0.66]}\end{array}$ & $\begin{array}{l}8.7 \mathrm{E}+2 \\
{[0.13]}\end{array}$ & $\begin{array}{l}2.4 \mathrm{E}+2 \\
{[0.01]}\end{array}$ & $\begin{array}{l}6.0 \mathrm{E}+2 \\
{[0.53]}\end{array}$ & $\begin{array}{l}1.5 \mathrm{E}+2 \\
{[0.80]}\end{array}$ & $\begin{array}{l}3.1 \mathrm{E}+1 \\
{[0.13]}\end{array}$ \\
\hline & 5.42 & $\begin{array}{l}1.3 \mathrm{E}+3 \\
{[0.68]}\end{array}$ & $\begin{array}{l}1.2 \mathrm{E}+3 \\
{[0.22]}\end{array}$ & $\begin{array}{l}3.8 \mathrm{E}+3 \\
{[0.45]}\end{array}$ & $\begin{array}{l}\mathrm{ND} \\
{[0.00]}\end{array}$ & $\begin{array}{l}4.1 \mathrm{E}+1 \\
{[0.00]}\end{array}$ & $\begin{array}{c}2.5 \mathrm{E}+2 \\
{[0.22]}\end{array}$ & $\begin{array}{l}1.5 \mathrm{E}+2 \\
{[0.80]}\end{array}$ & $\begin{array}{l}1.4 \mathrm{E}+0 \\
{[0.01]}\end{array}$ \\
\hline & 5.94 & $\begin{array}{l}1.4 \mathrm{E}+3 \\
{[0.73]}\end{array}$ & $\begin{array}{l}1.2 \mathrm{E}+3 \\
{[0.22]}\end{array}$ & $\begin{array}{l}3.9 \mathrm{E}+3 \\
{[0.46]}\end{array}$ & $\begin{array}{l}\mathrm{ND} \\
{[0.00]}\end{array}$ & $\begin{array}{l}4.7 \mathrm{E}+1 \\
{[0.00]}\end{array}$ & $\begin{array}{c}2.5 \mathrm{E}+2 \\
{[0.22]}\end{array}$ & $\begin{array}{l}1.6 \mathrm{E}+2 \\
{[0.85]}\end{array}$ & $\begin{array}{l}7.2 \mathrm{E}-3 \\
{[0.00]}\end{array}$ \\
\hline & 7.72 & $\begin{array}{l}1.1 \mathrm{E}+3 \\
{[0.57]}\end{array}$ & $\begin{array}{l}3.3 \mathrm{E}+2 \\
{[0.06]}\end{array}$ & $\begin{array}{l}2.6 \mathrm{E}+3 \\
{[0.31]}\end{array}$ & $\begin{array}{l}6.3 \mathrm{E}-2 \\
{[0.00]}\end{array}$ & $\begin{array}{l}5.8 \mathrm{E}+2 \\
{[0.02]}\end{array}$ & $\begin{array}{l}7.0 \mathrm{E}+1 \\
{[0.06]}\end{array}$ & $\begin{array}{l}1.6 \mathrm{E}+2 \\
{[0.85]}\end{array}$ & $\begin{array}{l}\mathrm{ND} \\
{[0.00]}\end{array}$ \\
\hline & 7.85 & $\begin{array}{l}1.1 \mathrm{E}+3 \\
{[0.57]}\end{array}$ & $\begin{array}{l}2.8 \mathrm{E}+2 \\
{[0.05]}\end{array}$ & $\begin{array}{l}2.7 \mathrm{E}+3 \\
{[0.32]}\end{array}$ & $\begin{array}{l}5.0 \mathrm{E}-2 \\
{[0.00]}\end{array}$ & $\begin{array}{l}4.7 \mathrm{E}+2 \\
{[0.02]}\end{array}$ & $\begin{array}{c}5.8 \mathrm{E}+1 \\
{[0.05]}\end{array}$ & $\begin{array}{l}1.7 \mathrm{E}+2 \\
{[0.90]}\end{array}$ & $\begin{array}{l}\mathrm{ND} \\
{[0.00]}\end{array}$ \\
\hline & 12.2 & $\begin{array}{l}4.8 \mathrm{E}+2 \\
{[0.25]}\end{array}$ & $\begin{array}{l}1.3 \mathrm{E}+0 \\
{[0.00]}\end{array}$ & $\begin{array}{l}9.7 \mathrm{E}+2 \\
{[0.12]}\end{array}$ & $\begin{array}{l}1.8 \mathrm{E}+1 \\
{[0.00]}\end{array}$ & $\begin{array}{l}3.5 \mathrm{E}+1 \\
{[0.00]}\end{array}$ & $\begin{array}{l}\mathrm{ND} \\
{[0.00]}\end{array}$ & $\begin{array}{l}2.6 \mathrm{E}+2 \\
{[1.38]}\end{array}$ & $\begin{array}{l}\mathrm{ND} \\
{[0.00]}\end{array}$ \\
\hline & 12.2 & $\begin{array}{l}5.0 \mathrm{E}+2 \\
{[0.26]}\end{array}$ & $\begin{array}{l}3.5 \mathrm{E}+0 \\
{[0.00]}\end{array}$ & $\begin{array}{l}1.0 \mathrm{E}+3 \\
{[0.12]}\end{array}$ & $\begin{array}{l}1.8 \mathrm{E}+1 \\
{[0.00]}\end{array}$ & $\begin{array}{l}3.7 \mathrm{E}+1 \\
{[0.00]}\end{array}$ & $\begin{array}{l}5.5 \mathrm{E}-2 \\
{[0.00]}\end{array}$ & $\begin{array}{l}2.6 \mathrm{E}+2 \\
{[1.38]}\end{array}$ & $\begin{array}{l}\mathrm{ND} \\
{[0.00]}\end{array}$ \\
\hline \multirow{8}{*}{$\begin{array}{l}\text { Geopolymer } \\
\text { Batch \#2 }\end{array}$} & 3.79 & $\begin{array}{l}1.7 \mathrm{E}+3 \\
{[0.94]}\end{array}$ & $\begin{array}{l}2.8 \mathrm{E}+3 \\
{[0.55]}\end{array}$ & $\begin{array}{l}5.1 \mathrm{E}+3 \\
{[0.64]}\end{array}$ & $\begin{array}{l}4.5 \mathrm{E}+2 \\
{[0.07]}\end{array}$ & $\begin{array}{l}1.9 \mathrm{E}+2 \\
{[0.01]}\end{array}$ & $\begin{array}{c}5.6 \mathrm{E}+2 \\
{[0.50]}\end{array}$ & $\begin{array}{l}1.7 \mathrm{E}+2 \\
{[0.90]}\end{array}$ & $\begin{array}{l}2.4 \mathrm{E}+1 \\
{[0.10]}\end{array}$ \\
\hline & 4.04 & $\begin{array}{l}1.7 \mathrm{E}+3 \\
{[0.94]}\end{array}$ & $\begin{array}{l}3.1 \mathrm{E}+3 \\
{[0.61]}\end{array}$ & $\begin{array}{l}5.2 \mathrm{E}+3 \\
{[0.66]}\end{array}$ & $\begin{array}{l}2.9 \mathrm{E}+2 \\
{[0.04]}\end{array}$ & $\begin{array}{l}1.5 \mathrm{E}+2 \\
{[0.01]}\end{array}$ & $\begin{array}{l}6.3 \mathrm{E}+2 \\
{[0.56]}\end{array}$ & $\begin{array}{l}1.8 \mathrm{E}+2 \\
{[0.95]}\end{array}$ & $\begin{array}{l}2.2 \mathrm{E}+1 \\
{[0.09]}\end{array}$ \\
\hline & 6.41 & $\begin{array}{l}1.3 \mathrm{E}+3 \\
{[0.72]}\end{array}$ & $\begin{array}{l}9.9 \mathrm{E}+2 \\
{[0.19]}\end{array}$ & $\begin{array}{l}3.4 \mathrm{E}+3 \\
{[0.43]}\end{array}$ & $\begin{array}{l}\text { ND } \\
{[0.00]}\end{array}$ & $\begin{array}{l}1.3 \mathrm{E}+1 \\
{[0.00]}\end{array}$ & $\begin{array}{c}2.0 \mathrm{E}+2 \\
{[0.18]}\end{array}$ & $\begin{array}{l}1.7 \mathrm{E}+2 \\
{[0.90]}\end{array}$ & $\begin{array}{l}\mathrm{ND} \\
{[0.00]}\end{array}$ \\
\hline & 6.58 & $\begin{array}{l}1.4 \mathrm{E}+3 \\
{[0.78]}\end{array}$ & $\begin{array}{l}1.0 \mathrm{E}+3 \\
{[0.20]}\end{array}$ & $\begin{array}{l}3.4 \mathrm{E}+3 \\
{[0.43]}\end{array}$ & $\begin{array}{l}\mathrm{ND} \\
{[0.00]}\end{array}$ & $\begin{array}{l}1.1 \mathrm{E}+1 \\
{[0.00]}\end{array}$ & $\begin{array}{c}2.1 \mathrm{E}+2 \\
{[0.19]}\end{array}$ & $\begin{array}{l}1.7 \mathrm{E}+2 \\
{[0.90]}\end{array}$ & $\begin{array}{l}\mathrm{ND} \\
{[0.00]}\end{array}$ \\
\hline & 8.25 & $\begin{array}{l}1.1 \mathrm{E}+3 \\
{[0.61]}\end{array}$ & $\begin{array}{l}2.0 \mathrm{E}+2 \\
{[0.04]}\end{array}$ & $\begin{array}{l}2.4 \mathrm{E}+3 \\
{[0.30]}\end{array}$ & $\begin{array}{l}4.1 \mathrm{E}-2 \\
{[0.00]}\end{array}$ & $\begin{array}{l}4.6 \mathrm{E}+0 \\
{[0.00]}\end{array}$ & $\begin{array}{l}3.1 \mathrm{E}+1 \\
{[0.03]}\end{array}$ & $\begin{array}{l}2.1 \mathrm{E}+2 \\
{[1.11]}\end{array}$ & $\begin{array}{l}\mathrm{ND} \\
{[0.00]}\end{array}$ \\
\hline & 8.38 & $\begin{array}{l}1.1 \mathrm{E}+3 \\
{[0.61]}\end{array}$ & $\begin{array}{l}2.0 \mathrm{E}+2 \\
{[0.04]}\end{array}$ & $\begin{array}{l}2.4 \mathrm{E}+3 \\
{[0.30]}\end{array}$ & $\begin{array}{l}2.9 \mathrm{E}-2 \\
{[0.00]}\end{array}$ & $\begin{array}{l}3.8 \mathrm{E}+0 \\
{[0.00]}\end{array}$ & $\begin{array}{c}3.1 \mathrm{E}+1 \\
{[0.03]}\end{array}$ & $\begin{array}{l}2.1 \mathrm{E}+2 \\
{[1.11]}\end{array}$ & $\begin{array}{l}\text { ND } \\
{[0.00]}\end{array}$ \\
\hline & 12.0 & $\begin{array}{l}4.8 \mathrm{E}+2 \\
{[0.27]}\end{array}$ & $\begin{array}{l}8.7 \mathrm{E}-1 \\
{[0.00]}\end{array}$ & $\begin{array}{l}8.7 \mathrm{E}+2 \\
{[0.11]}\end{array}$ & $\begin{array}{l}1.1 \mathrm{E}+1 \\
{[0.00]}\end{array}$ & $\begin{array}{l}3.9 \mathrm{E}+1 \\
{[0.00]}\end{array}$ & $\begin{array}{l}\mathrm{ND} \\
{[0.00]}\end{array}$ & $\begin{array}{l}2.7 \mathrm{E}+2 \\
{[1.43]}\end{array}$ & $\begin{array}{l}\mathrm{ND} \\
{[0.00]}\end{array}$ \\
\hline & 12.0 & $\begin{array}{l}4.8 \mathrm{E}+2 \\
{[0.27]}\end{array}$ & $\begin{array}{l}1.2 \mathrm{E}+0 \\
{[0.00]}\end{array}$ & $\begin{array}{l}8.7 \mathrm{E}+2 \\
{[0.11]}\end{array}$ & $\begin{array}{l}1.0 \mathrm{E}+1 \\
{[0.00]}\end{array}$ & $\begin{array}{l}3.8 \mathrm{E}+1 \\
{[0.00]}\end{array}$ & $\begin{array}{c}6.2 \mathrm{E}-3 \\
{[0.00]}\end{array}$ & $\begin{array}{l}2.8 \mathrm{E}+2 \\
{[1.48]}\end{array}$ & $\begin{array}{l}\mathrm{ND} \\
{[0.00]}\end{array}$ \\
\hline
\end{tabular}

(a) Percentage of leaching (\%) is also shown in bracket, [ ] below measured concentrations (mg/L).

(b) ND indicates "not detected" below quantification level for Fe $(<7.0 \mathrm{E}-4 \mathrm{mg} / \mathrm{L})$; $\mathrm{Al}(<6.3 \mathrm{E}-4 \mathrm{mg} / \mathrm{L})$. 
Table 5.6. The Concentrations of RCRA Metals in Eluate for Waste Forms from 1313 Method $^{(a)}$

\begin{tabular}{|c|c|c|c|c|c|c|}
\hline Waste Forms & $\mathrm{pH}$ & $\begin{array}{c}\mathrm{Cd} \\
(\mu \mathrm{g} / \mathrm{L})\end{array}$ & $\begin{array}{c}\mathrm{Cr} \\
(\mu \mathrm{g} / \mathrm{L})\end{array}$ & $\begin{array}{c}\mathrm{Pb} \\
(\mu \mathrm{g} / \mathrm{L})\end{array}$ & $\begin{array}{c}\mathrm{Ag} \\
(\mu \mathrm{g} / \mathrm{L})\end{array}$ & $\begin{array}{c}\mathrm{Hg} \\
(\mu \mathrm{g} / \mathrm{L})\end{array}$ \\
\hline \multirow{10}{*}{ Cast Stone } & 3.62 & $\begin{array}{l}\mathrm{ND}^{(\mathbf{b})} \\
{[0.00]}\end{array}$ & $\begin{array}{l}272 \\
{[7.29]}\end{array}$ & $\begin{array}{c}\mathrm{ND} \\
{[0.00]}\end{array}$ & $\begin{array}{c}2.76 \\
{[0.88]}\end{array}$ & $\begin{array}{l}\mathrm{ND} \\
{[0.00]}\end{array}$ \\
\hline & 3.68 & $\begin{array}{l}\text { ND } \\
{[0.00]}\end{array}$ & $\begin{array}{l}268 \\
{[7.18]}\end{array}$ & $\begin{array}{c}\text { ND } \\
{[0.00]}\end{array}$ & $\begin{array}{c}3.33 \\
{[1.06]}\end{array}$ & $\begin{array}{l}\text { ND } \\
{[0.00]}\end{array}$ \\
\hline & 4.31 & $\begin{array}{c}\text { ND } \\
{[0.00]}\end{array}$ & $\begin{array}{c}19.6 \\
{[0.53]}\end{array}$ & $\begin{array}{c}\text { ND } \\
{[0.00]}\end{array}$ & $\begin{array}{c}3.04 \\
{[0.97]}\end{array}$ & $\begin{array}{l}\text { ND } \\
{[0.00]}\end{array}$ \\
\hline & 4.36 & $\begin{array}{c}\text { ND } \\
{[0.00]}\end{array}$ & $\begin{array}{c}30.8 \\
{[0.83]}\end{array}$ & $\begin{array}{c}\mathrm{ND} \\
{[0.00]}\end{array}$ & $\begin{array}{c}3.07 \\
{[0.97]}\end{array}$ & $\begin{array}{l}\text { ND } \\
{[0.00]}\end{array}$ \\
\hline & 6.76 & $\begin{array}{l}\text { ND } \\
{[0.00]}\end{array}$ & $\begin{array}{c}1.90 \\
{[0.05]}\end{array}$ & $\begin{array}{l}\text { ND } \\
{[0.00]}\end{array}$ & $\begin{array}{c}3.12 \\
{[0.99]}\end{array}$ & $\begin{array}{r}4.03 \\
{[10.5]}\end{array}$ \\
\hline & 7.63 & $\begin{array}{c}1.95 \\
{[0.15]}\end{array}$ & $\begin{array}{c}6.40 \\
{[0.17]}\end{array}$ & $\begin{array}{c}\text { ND } \\
{[0.00]}\end{array}$ & $\begin{array}{c}3.53 \\
{[1.12]}\end{array}$ & $\begin{array}{r}4.86 \\
{[12.7]}\end{array}$ \\
\hline & 10.0 & $\begin{array}{l}\text { ND } \\
{[0.00]}\end{array}$ & $\begin{array}{c}46.9 \\
{[1.26]}\end{array}$ & $\begin{array}{c}\mathrm{ND} \\
{[0.00]}\end{array}$ & $\begin{array}{c}2.58 \\
{[0.82]}\end{array}$ & $\begin{array}{r}7.29 \\
{[19.0]}\end{array}$ \\
\hline & 10.1 & $\begin{array}{c}0.47 \\
{[0.04]}\end{array}$ & $\begin{array}{c}52.8 \\
{[1.42]}\end{array}$ & $\begin{array}{l}\text { ND } \\
{[0.00]}\end{array}$ & $\begin{array}{c}3.31 \\
{[1.05]}\end{array}$ & $\begin{array}{r}8.15 \\
{[21.3]}\end{array}$ \\
\hline & 12.3 & $\begin{array}{c}\text { ND } \\
{[0.00]}\end{array}$ & $\begin{array}{c}28.0 \\
{[0.75]}\end{array}$ & $\begin{array}{c}\text { ND } \\
{[0.00]}\end{array}$ & $\begin{array}{c}2.53 \\
{[0.80]}\end{array}$ & $\begin{array}{c}11.4 \\
{[29.8]}\end{array}$ \\
\hline & 12.3 & $\begin{array}{l}\text { ND } \\
{[0.00]}\end{array}$ & $\begin{array}{c}31.1 \\
{[0.83]}\end{array}$ & $\begin{array}{c}\mathrm{ND} \\
{[0.00]}\end{array}$ & $\begin{array}{c}1.75 \\
{[0.56]}\end{array}$ & $\begin{array}{c}13.0 \\
{[33.9]}\end{array}$ \\
\hline \multirow{8}{*}{$\begin{array}{l}\text { Geopolymer } \\
\text { Batch \#1 }\end{array}$} & 3.66 & $\begin{array}{c}\mathrm{ND} \\
{[0.00]}\end{array}$ & $\begin{array}{l}101 \\
{[3.90]}\end{array}$ & $\begin{array}{c}\mathrm{ND} \\
{[0.00]}\end{array}$ & $\begin{array}{c}7.53 \\
{[0.01]}\end{array}$ & $\begin{array}{c}0.17 \\
{[0.09]}\end{array}$ \\
\hline & 3.72 & $\begin{array}{l}\text { ND } \\
{[0.00]}\end{array}$ & $\begin{array}{l}164 \\
{[6.33]}\end{array}$ & $\begin{array}{c}\mathrm{ND} \\
{[0.00]}\end{array}$ & $\begin{array}{c}5.60 \\
{[0.01]}\end{array}$ & $\begin{array}{c}0.12 \\
{[0.06]}\end{array}$ \\
\hline & 5.42 & $\begin{array}{c}\text { ND } \\
{[0.00]}\end{array}$ & $\begin{array}{l}\mathrm{ND} \\
{[0.00]}\end{array}$ & $\begin{array}{c}\mathrm{ND} \\
{[0.00]}\end{array}$ & $\begin{array}{c}2.74 \\
{[0.00]}\end{array}$ & $\begin{array}{c}2.69 \\
{[1.42]}\end{array}$ \\
\hline & 5.94 & $\begin{array}{c}\text { ND } \\
{[0.00]}\end{array}$ & $\begin{array}{l}\mathrm{ND} \\
{[0.00]}\end{array}$ & $\begin{array}{c}\text { ND } \\
{[0.00]}\end{array}$ & $\begin{array}{c}2.68 \\
{[0.00]}\end{array}$ & $\begin{array}{c}4.81 \\
{[2.53]}\end{array}$ \\
\hline & 7.72 & $\begin{array}{l}\mathrm{ND} \\
{[0.00]}\end{array}$ & $\begin{array}{c}1.70 \\
{[0.07]}\end{array}$ & $\begin{array}{c}\mathrm{ND} \\
{[0.00]}\end{array}$ & $\begin{array}{c}2.52 \\
{[0.00]}\end{array}$ & $\begin{array}{c}24.2 \\
{[12.7]}\end{array}$ \\
\hline & 7.85 & $\begin{array}{c}\text { ND } \\
{[0.00]}\end{array}$ & $\begin{array}{l}\mathrm{ND} \\
{[0.00]}\end{array}$ & $\begin{array}{c}\text { ND } \\
{[0.00]}\end{array}$ & $\begin{array}{c}2.38 \\
{[0.00]}\end{array}$ & $\begin{array}{c}27.6 \\
{[14.5]}\end{array}$ \\
\hline & 12.2 & $\begin{array}{l}\text { ND } \\
{[0.00]}\end{array}$ & $\begin{array}{c}38.5 \\
{[1.49]}\end{array}$ & $\begin{array}{c}\mathrm{ND} \\
{[0.00]}\end{array}$ & $\begin{array}{c}2.50 \\
{[0.00]}\end{array}$ & $\begin{array}{c}66.4 \\
{[35.0]}\end{array}$ \\
\hline & 12.2 & $\begin{array}{c}\text { ND } \\
{[0.00]}\end{array}$ & $\begin{array}{c}45.0 \\
{[1.74]}\end{array}$ & $\begin{array}{c}\mathrm{ND} \\
{[0.00]}\end{array}$ & $\begin{array}{c}2.79 \\
{[0.00]}\end{array}$ & $\begin{array}{c}68.9 \\
{[36.3]}\end{array}$ \\
\hline \multirow{5}{*}{$\begin{array}{c}\text { Geopolymer } \\
\text { Batch } \# 2\end{array}$} & 3.79 & $\begin{array}{c}\text { ND } \\
{[0.00]}\end{array}$ & $\begin{array}{c}44.3 \\
{[1.55]}\end{array}$ & $\begin{array}{l}\text { ND } \\
{[0.00]}\end{array}$ & $\begin{array}{c}5.18 \\
{[0.01]}\end{array}$ & $\begin{array}{c}0.22 \\
{[0.07]}\end{array}$ \\
\hline & 4.04 & $\begin{array}{l}\text { ND } \\
{[0.00]}\end{array}$ & $\begin{array}{c}35.5 \\
{[1.25]}\end{array}$ & $\begin{array}{c}\mathrm{ND} \\
{[0.00]}\end{array}$ & $\begin{array}{c}4.68 \\
{[0.01]}\end{array}$ & $\begin{array}{r}0.18 \\
{[0.06]}\end{array}$ \\
\hline & 6.41 & $\begin{array}{l}\text { ND } \\
{[0.00]}\end{array}$ & $\begin{array}{l}\mathrm{ND} \\
{[0.00]}\end{array}$ & $\begin{array}{c}\text { ND } \\
{[0.00]}\end{array}$ & $\begin{array}{c}5.41 \\
{[0.01]}\end{array}$ & $\begin{array}{c}3.33 \\
{[1.11]}\end{array}$ \\
\hline & 6.58 & $\begin{array}{c}\text { ND } \\
{[0.00]}\end{array}$ & $\begin{array}{l}\mathrm{ND} \\
{[0.00]}\end{array}$ & $\begin{array}{c}\text { ND } \\
{[0.00]}\end{array}$ & $\begin{array}{c}6.57 \\
{[0.01]}\end{array}$ & $\begin{array}{c}3.60 \\
{[1.20]}\end{array}$ \\
\hline & 8.25 & $\begin{array}{c}\text { ND } \\
{[0.00]}\end{array}$ & $\begin{array}{l}\text { ND } \\
{[0.00]}\end{array}$ & $\begin{array}{c}\text { ND } \\
{[0.00]}\end{array}$ & $\begin{array}{c}5.77 \\
{[0.01]}\end{array}$ & $\begin{array}{c}9.43 \\
{[3.13]}\end{array}$ \\
\hline
\end{tabular}


Table 5.6. (contd)

\begin{tabular}{ccccccc}
\hline \multirow{2}{*}{ Waste Forms } & $\mathrm{pH}$ & $\begin{array}{c}\mathrm{Cd} \\
(\mu \mathrm{g} / \mathrm{L})\end{array}$ & $\begin{array}{c}\mathrm{Cr} \\
(\mu \mathrm{g} / \mathrm{L})\end{array}$ & $\begin{array}{c}\mathrm{Pb} \\
(\mu \mathrm{g} / \mathrm{L})\end{array}$ & $\begin{array}{c}\mathrm{Ag} \\
(\mu \mathrm{g} / \mathrm{L})\end{array}$ & $\begin{array}{c}\mathrm{Hg} \\
(\mu \mathrm{g} / \mathrm{L})\end{array}$ \\
\cline { 2 - 6 } & 8.38 & $\mathrm{ND}$ & $\mathrm{ND}$ & $\mathrm{ND}$ & 6.37 & 9.65 \\
Geopolymer & & {$[0.00]$} & {$[0.00]$} & {$[0.00]$} & {$[0.01]$} & {$[3.21]$} \\
Batch \#2 (contd) & \multirow{2}{*}{12.0} & $\mathrm{ND}$ & 59.0 & $\mathrm{ND}$ & 4.41 & 12.5 \\
& & {$[0.00]$} & {$[2.07]$} & {$[0.00]$} & {$[0.01]$} & {$[4.15]$} \\
& \multirow{2}{*}{12.0} & $\mathrm{ND}$ & 38.0 & $\mathrm{ND}$ & 5.74 & 14.0 \\
& {$[0.00]$} & {$[1.33]$} & {$[0.00]$} & {$[0.01]$} & {$[4.65]$} \\
\hline
\end{tabular}

(a) Percentage of leaching $(\%)$ is also shown in bracket, [ ] below measured concentrations $(\mu \mathrm{g} / \mathrm{L})$.

(b) ND indicates "not detected" below quantification level for As $(<5.7 \mathrm{E}-2 \mu \mathrm{g} / \mathrm{L})$; $\mathrm{Cd}(<1.1 \mathrm{E}-2 \mu \mathrm{g} / \mathrm{L}) ; \mathrm{Cr}(<6.9 \mathrm{E}-2 \mu \mathrm{g} / \mathrm{L}) ; \mathrm{Pb}(<2.7 \mathrm{E}-2 \mu \mathrm{g} / \mathrm{L})$; $\mathrm{Hg}(<3.6 \mathrm{E}-4 \mu \mathrm{g} / \mathrm{L}) ; \mathrm{Cu}(<2.5 \mathrm{E}-1 \mu \mathrm{g} / \mathrm{L})$.

Table 5.7. The Concentrations of Major Anions, ${ }^{99} \mathrm{Tc}$, and ${ }^{127} \mathrm{I}$ in Eluate for Waste Forms from 1313 Method

\begin{tabular}{|c|c|c|c|c|c|c|c|c|}
\hline Waste Forms & $\mathrm{pH}$ & $\begin{array}{c}\mathrm{NO}_{3}^{-} \\
(\mathrm{mg} / \mathrm{L})\end{array}$ & $\begin{array}{l}\mathrm{PO}_{4}{ }^{3-} \\
(\mathrm{mg} / \mathrm{L})\end{array}$ & $\begin{array}{c}\mathrm{PO}_{4}^{3-} \\
(\mathrm{mg} / \mathrm{L})^{(\mathrm{a})}\end{array}$ & $\begin{array}{c}\mathrm{SO}_{4}{ }^{2-} \\
(\mathrm{mg} / \mathrm{L})\end{array}$ & $\begin{array}{c}\mathrm{SO}_{4}{ }^{2} \\
(\mathrm{mg} / \mathrm{L})^{(\mathrm{a})}\end{array}$ & $\begin{array}{l}{ }^{99} \mathrm{Tc} \\
(\mu \mathrm{g} / \mathrm{L})\end{array}$ & $\begin{array}{c}{ }^{127} \mathrm{I} \\
(\mu \mathrm{g} / \mathrm{L})\end{array}$ \\
\hline \multirow{10}{*}{ Cast Stone } & 3.62 & ND & 50.2 & 11.5 & 1096 & 1552 & $\begin{array}{r}0.996 \\
{[6.23]^{(\mathrm{b})}}\end{array}$ & $\begin{array}{r}11.2 \\
{[<19.5]^{(b)}}\end{array}$ \\
\hline & 3.68 & 60902 & 42.7 & 11.1 & 1091 & 1509 & $\begin{array}{r}0.810 \\
{[5.06]}\end{array}$ & $\begin{array}{c}12.5 \\
{[<21.7]}\end{array}$ \\
\hline & 4.31 & 34824 & ND & 8.17 & 1529 & 1945 & $\begin{array}{r}1.025 \\
{[6.41]}\end{array}$ & $\begin{array}{c}10.8 \\
{[<18.8]}\end{array}$ \\
\hline & 4.36 & 34659 & ND & 8.78 & 1468 & 1899 & $\begin{array}{r}1.181 \\
{[7.38]}\end{array}$ & $\begin{array}{c}13.1 \\
{[<22.8]}\end{array}$ \\
\hline & 6.76 & 19895 & ND & 7.46 & 1228 & 1585 & $\begin{array}{c}2.348 \\
{[14.7]}\end{array}$ & $\begin{array}{r}13.5 \\
{[<23.5]}\end{array}$ \\
\hline & 7.63 & 20178 & ND & 6.52 & 1272 & 1627 & $\begin{array}{c}3.177 \\
{[19.9]}\end{array}$ & $\begin{array}{c}12.2 \\
{[<21.2]}\end{array}$ \\
\hline & 10.0 & 10272 & 48.9 & 5.00 & 722 & 953 & $\begin{array}{c}4.469 \\
{[27.9]}\end{array}$ & $\begin{array}{c}11.9 \\
{[<20.7]}\end{array}$ \\
\hline & 10.1 & 10628 & ND & 4.75 & 757 & 951 & $\begin{array}{c}4.730 \\
{[30.0]}\end{array}$ & $\begin{array}{c}11.3 \\
{[<19.7]}\end{array}$ \\
\hline & 12.3 & 150.3 & ND & ND & 144 & 362 & $\begin{array}{c}3.404 \\
{[21.3]}\end{array}$ & $\begin{array}{r}2.96 \\
{[<5.15]}\end{array}$ \\
\hline & 12.3 & 169.2 & ND & ND & 138 & 359 & $\begin{array}{c}3.663 \\
{[22.9]}\end{array}$ & $\begin{array}{r}4.70 \\
{[<8.17]}\end{array}$ \\
\hline \multirow{5}{*}{$\begin{array}{c}\text { Geopolymer } \\
\text { Batch \#1 }\end{array}$} & 3.66 & 30273 & ND & 7.77 & ND & 487 & $\begin{array}{r}5.07 \\
{[16.8]}\end{array}$ & $\begin{array}{c}32.2 \\
{[<64.8]}\end{array}$ \\
\hline & 3.72 & 28066 & ND & 8.28 & ND & 462 & $\begin{array}{r}5.00 \\
{[16.6]}\end{array}$ & $\begin{array}{c}29.2 \\
{[<58.8]}\end{array}$ \\
\hline & 5.42 & 13574 & ND & 4.16 & ND & 458 & $\begin{array}{r}6.68 \\
{[22.2]}\end{array}$ & $\begin{array}{c}28.1 \\
{[<56.5]}\end{array}$ \\
\hline & 5.94 & 13674 & ND & 4.52 & ND & 492 & $\begin{array}{r}6.90 \\
{[22.9]}\end{array}$ & $\begin{array}{c}29.2 \\
{[<58.8]}\end{array}$ \\
\hline & 7.72 & 7566 & ND & 2.56 & ND & 485 & $\begin{array}{r}7.88 \\
{[26.2]}\end{array}$ & $\begin{array}{c}27.7 \\
{[<55.7]}\end{array}$ \\
\hline
\end{tabular}


Table 5.7. (contd)

\begin{tabular}{|c|c|c|c|c|c|c|c|c|}
\hline Waste Forms & $\mathrm{pH}$ & $\begin{array}{c}\mathrm{NO}_{3}^{-} \\
(\mathrm{mg} / \mathrm{L})\end{array}$ & $\begin{array}{l}\mathrm{PO}_{4}{ }^{3-} \\
(\mathrm{mg} / \mathrm{L})\end{array}$ & $\begin{array}{c}\mathrm{PO}_{4}{ }^{3-} \\
(\mathrm{mg} / \mathrm{L})^{(\mathrm{a})}\end{array}$ & $\begin{array}{l}\mathrm{SO}_{4}{ }^{2-} \\
(\mathrm{mg} / \mathrm{L})\end{array}$ & $\begin{array}{c}\mathrm{SO}_{4}{ }^{2} \\
(\mathrm{mg} / \mathrm{L})^{(\mathrm{a})}\end{array}$ & $\begin{array}{l}{ }^{99} \mathrm{Tc} \\
(\mu \mathrm{g} / \mathrm{L})\end{array}$ & $\begin{array}{c}{ }^{127} \mathrm{I} \\
(\mu \mathrm{g} / \mathrm{L})\end{array}$ \\
\hline \multirow{3}{*}{$\begin{array}{c}\text { Geopolymer } \\
\text { Batch \#1 } \\
\text { (contd) }\end{array}$} & 7.85 & 7667 & ND & 2.11 & ND & 510 & $\begin{array}{r}7.98 \\
{[26.5]}\end{array}$ & $\begin{array}{r}28.3 \\
{[<56.9]}\end{array}$ \\
\hline & 12.2 & 625 & ND & 2.48 & 177 & 765 & $\begin{array}{r}8.77 \\
{[29.1]}\end{array}$ & $\begin{array}{r}28.9 \\
{[<58.2]}\end{array}$ \\
\hline & 12.2 & 646 & ND & 2.42 & 188 & 778 & $\begin{array}{r}9.32 \\
{[31.0]}\end{array}$ & $\begin{array}{r}29.9 \\
{[<60.1]}\end{array}$ \\
\hline \multirow{8}{*}{$\begin{array}{c}\text { Geopolymer } \\
\text { Batch } \# 2\end{array}$} & 3.79 & 25103 & ND & 6.73 & 149 & 513 & $\begin{array}{r}3.77 \\
{[16.5]}\end{array}$ & $\begin{array}{r}28.9 \\
{[<44.9]}\end{array}$ \\
\hline & 4.04 & 24706 & ND & 6.86 & 150 & 538 & $\begin{array}{r}3.70 \\
{[16.2]}\end{array}$ & $\begin{array}{r}28.5 \\
{[<43.3]}\end{array}$ \\
\hline & 6.41 & 11958 & ND & 4.44 & 145 & 504 & $\begin{array}{r}4.32 \\
{[18.9]}\end{array}$ & $\begin{array}{c}26.2 \\
{[<40.0]}\end{array}$ \\
\hline & 6.58 & 11986 & ND & 3.87 & 141 & 515 & $\begin{array}{r}4.37 \\
{[19.1]}\end{array}$ & $\begin{array}{r}26.5 \\
{[<40.2]}\end{array}$ \\
\hline & 8.25 & 6630 & 21.2 & 1.36 & 138 & 615 & $\begin{array}{r}4.56 \\
{[19.9]}\end{array}$ & $\begin{array}{r}25.2 \\
{[<38.2]}\end{array}$ \\
\hline & 8.38 & 6678 & ND & 1.91 & 139 & 642 & $\begin{array}{r}4.65 \\
{[20.3]}\end{array}$ & $\begin{array}{r}25.7 \\
{[<39.0]}\end{array}$ \\
\hline & 12.0 & 641 & 2.51 & 1.43 & 142 & 819 & $\begin{array}{r}2.97 \\
{[13.0]}\end{array}$ & $\begin{array}{r}25.8 \\
{[<39.2]}\end{array}$ \\
\hline & 12.0 & 645 & ND & 1.16 & 144 & 829 & $\begin{array}{r}2.95 \\
{[12.9]}\end{array}$ & $\begin{array}{c}27.1 \\
{[<41.1]}\end{array}$ \\
\hline
\end{tabular}

(a) $\mathrm{PO}_{4}{ }^{3-}$ and $\mathrm{SO}_{4}{ }^{2-}$ were also calculated based on phosphorus and sulfur concentrations analyzed by ICP-OES. ND indicates "not detected" below quantification level for $\mathrm{NO}_{3}{ }^{-}(<1.0 \mathrm{mg} / \mathrm{L}) ; \mathrm{PO}_{4}{ }^{3-}(<1.5 \mathrm{mg} / \mathrm{L}$ by IC and $<4.0 \mathrm{mg} / \mathrm{L}$ by ICP-OES $) ; \mathrm{SO}_{4}{ }^{2-}(<1.5 \mathrm{mg} / \mathrm{L}$ by IC).

(b) Percentage of leaching (\%) is also shown in bracket, [ ] below measured concentrations $(\mathrm{mg} / \mathrm{L})$. Because of low concentration of spiked iodine, leaching percentage of iodide was calculated based on the instrumental MDL (See Tables 5.1 and 5.3).

\subsection{EPA Method 1316}

The results of $\mathrm{pH}, \mathrm{EC}$, Eh, and alkalinity for the leached Cast Stone, Geopolymer batch \#1, and Geopolymer batch \#2 are shown in Table 5.8. In Method 1316, the liquid-to-solid ratio is varied $(10,5$, and $2 \mathrm{~mL} / \mathrm{g})$ to evaluate how these changes will impact the leaching characteristics of the constituents of interest. Given the highly alkaline solution that results from equilibrating DI water with the Cast Stone and Geopolymer samples, the majority of the measured pHs are between $\mathrm{pH} 12$ and 13, irrespective of the changes in the liquid-to-solid ratio. Higher EC and alkalinity values were measured in eluate solutions at the lower liquid-to-solid ratio. The observed decrease in EC and alkalinity with an increase in the liquid-to-solid ratio is probably the result of a dilution effect. Because the measured EC and alkalinity at $10 \mathrm{~mL} / \mathrm{g}$ were slightly higher than the calculated EC and alkalinity for $10 \mathrm{~mL} / \mathrm{g}$ using those measured at 5 and $2 \mathrm{~mL} / \mathrm{g}$ ratio divided by 2 and 5 dilution factors, proportionately more dissolution of the three waste forms occurred as the volume of solution used in Method 1316 was increased.

Furthermore, the Eh decreased with decreasing liquid-to-solid ratio, indicating the pore solution becomes more reducing as the waste form is contacting less leachant. This suggest that the waste form inherently exhibit excess reducing capacity. 
Table 5.8. The Values of $\mathrm{pH}, \mathrm{EC}$, Eh, and Alkalinity of Three Waste Forms Measured from the EPA Method 1316

\begin{tabular}{|c|c|c|c|c|c|}
\hline Waste Forms & $\mathrm{pH}$ & $\begin{array}{c}\text { LS ratio } \\
(\mathrm{mL} / \mathrm{g})\end{array}$ & $\begin{array}{c}\mathrm{EC} \\
(\mathrm{mS} / \mathrm{cm})\end{array}$ & $\begin{array}{c}\mathrm{Eh} \\
(\mathrm{mV})\end{array}$ & $\begin{array}{c}\text { Alkalinity } \\
\left(\mathrm{mg} / \mathrm{L} \text { as } \mathrm{CaCO}_{3}\right)\end{array}$ \\
\hline \multirow{6}{*}{ Cast Stone } & 12.3 & 10 & 5.38 & 118 & 989 \\
\hline & 12.3 & 10 & 5.22 & 114 & 889 \\
\hline & 12.3 & 5 & 8.69 & 84.0 & 1526 \\
\hline & 12.4 & 5 & 8.70 & 94.0 & 1537 \\
\hline & 12.5 & 2 & $\mathrm{NA}^{(\mathbf{a})}$ & NA & NA \\
\hline & 12.6 & 2 & NA & NA & NA \\
\hline \multirow{6}{*}{$\begin{array}{c}\text { Geopolymer } \\
\text { Batch \#1 }\end{array}$} & 12.2 & 10 & 6.94 & 137 & 1248 \\
\hline & 12.2 & 10 & 7.22 & 133 & 1302 \\
\hline & 12.4 & 5 & 11.1 & 104 & 1874 \\
\hline & 12.5 & 5 & 11.0 & 110 & 1854 \\
\hline & 12.6 & 2 & 20.9 & 92.8 & 3008 \\
\hline & 12.7 & 2 & 21.0 & 96.8 & 3102 \\
\hline \multirow{6}{*}{$\begin{array}{c}\text { Geopolymer } \\
\text { Batch \#2 }\end{array}$} & 12.0 & 10 & 6.25 & 138 & 1013 \\
\hline & 12.0 & 10 & 6.16 & 142 & 1067 \\
\hline & 12.0 & 5 & 9.15 & 113 & 1520 \\
\hline & 12.0 & 5 & 9.08 & 112 & 1446 \\
\hline & 12.1 & 2 & 16.9 & 92.0 & 2241 \\
\hline & 12.1 & 2 & 16.8 & 95.8 & 2175 \\
\hline
\end{tabular}

(a) NA indicates "Not Available" because of low volume of sample precluded making the measurement.

The ${ }^{99} \mathrm{Tc}$ concentration release into the eluant and percent leached for each waste form is shown as function of the liquid-to-solid ratio in Figure 5.16. The leached ${ }^{99} \mathrm{Tc}$ concentration decreased in the eluates as liquid-to-solid ratio increased, indicating the higher liquid-to-solid ratio is effectively diluting the sample. For each liquid-to-solid ratio, the concentration of ${ }^{99} \mathrm{Tc}$ leached from Cast Stone and Geopolymer batch \#2 were lower than Geopolymer batch \#1. Finally, the percentage of the total ${ }^{99} \mathrm{Tc}$ leached from these samples ranged from 19 percent to 23 percent for Cast Stone, 24 percent to 31 percent for Geopolymer batch \#1, and 13 percent to 18 percent for Geopolymer batch \#2. It is important to note these experiments were conducted using a crushed sample of Cast Stone and Geopolymer at multiple solution volume-to-solids mass ratios. By using $<0.30$-mm sized material, the percent leached are expected to be high in comparison to the monolith samples of the same material. 

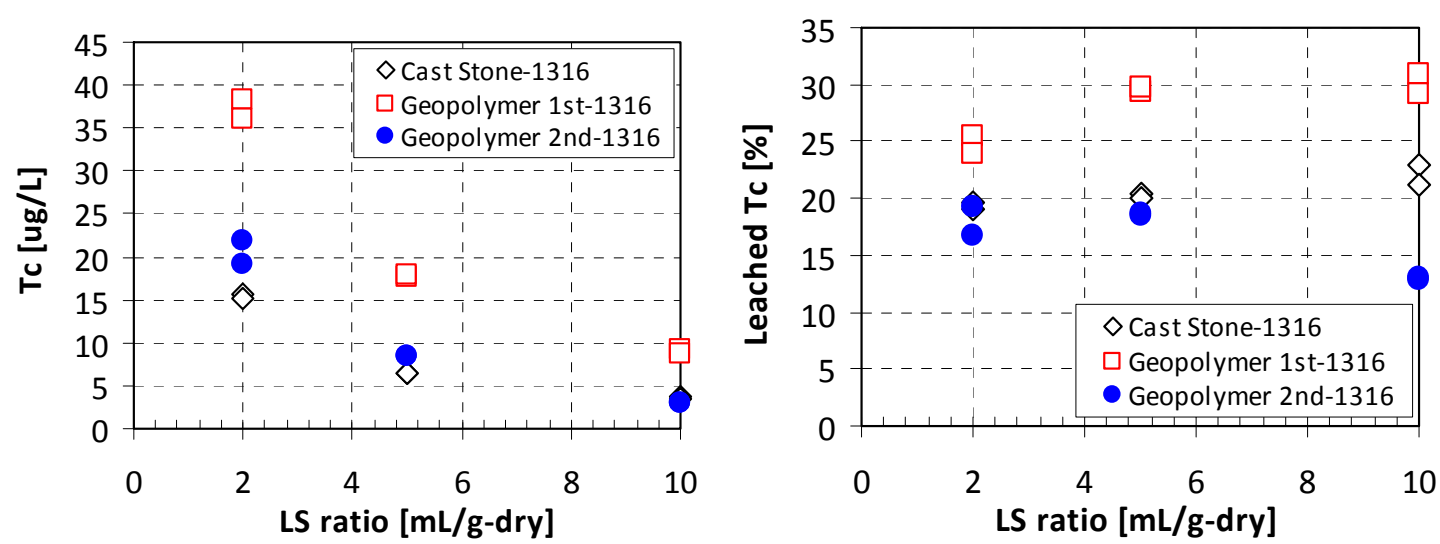

Figure 5.16. Leached Tc of Three Waste Forms in Method 1316. Tc concentration in eluate (left) and leached Tc (\%) based on total Tc concentration on each waste form (right)

The measured concentrations of major cations, RCRA metals, and anions are shown in Table 5.9 through Table 5.11. Major cations and anions also showed higher dissolved concentrations in low liquidto-solid ratio samples than high liquid-to-solid ratio samples. For all three waste forms, the predominant cation is sodium. In addition, Cast Stone showed about 10-times higher calcium concentration than the Geopolymer samples. Decreasing calcium concentration with decreased liquid-to-solid ratios in Cast Stone also suggested the possibility of calcite precipitate at the high $\mathrm{pH}$ of the Cast Stone leach solutions. The measured RCRA metals are shown in Table 5.10 and indicate higher concentrations in low liquid-tosolid ratio samples as was found for technetium and major cations. No detectable lead, copper, or cadmium were found in eluants from the three waste forms. In the eluants from the three waste forms, the dominant anions are $\mathrm{NO}_{3}{ }^{-}$and $\mathrm{CO}_{3}{ }^{2-}$ (Table 5.11). Leached ${ }^{127}$ I was also measured, and slightly higher iodide leaching was found in the Geopolymer samples than Cast Stone.

Table 5.9. The Concentrations of Major Cations in Eluate for Waste Forms from 1316 Method

\begin{tabular}{|c|c|c|c|c|c|c|c|c|c|}
\hline Waste Forms & LS & $\begin{array}{c}\mathrm{Na} \\
(\mathrm{mg} / \mathrm{L})\end{array}$ & $\begin{array}{c}\mathrm{Ca} \\
(\mathrm{mg} / \mathrm{L})\end{array}$ & $\begin{array}{c}\mathrm{K} \\
(\mathrm{mg} / \mathrm{L})\end{array}$ & $\begin{array}{c}\mathrm{Al} \\
(\mathrm{mg} / \mathrm{L})\end{array}$ & $\begin{array}{c}\mathrm{Si} \\
(\mathrm{mg} / \mathrm{L})\end{array}$ & $\begin{array}{c}\mathrm{Mg} \\
(\mathrm{mg} / \mathrm{L})\end{array}$ & $\begin{array}{c}\mathrm{S} \\
(\mathrm{mg} / \mathrm{L})\end{array}$ & $\begin{array}{c}\mathrm{Fe} \\
(\mathrm{mg} / \mathrm{L})\end{array}$ \\
\hline \multirow{6}{*}{ Cast Stone } & 10 & $\begin{array}{c}5.3 \mathrm{E}+2 \\
{[0.26]^{(\mathrm{a})}}\end{array}$ & $\begin{array}{c}3.4 \mathrm{E}+1 \\
{[0.00]}\end{array}$ & $\begin{array}{c}4.7 \mathrm{E}+1 \\
{[0.12]}\end{array}$ & $\begin{array}{c}1.7 \mathrm{E}+1 \\
{[0.01]}\end{array}$ & $\begin{array}{c}1.3 \mathrm{E}+1 \\
{[0.00]}\end{array}$ & $\begin{array}{c}4.3 \mathrm{E}-2 \\
{[0.00]}\end{array}$ & $\begin{array}{l}1.2 \mathrm{E}+2 \\
{[0.18]}\end{array}$ & $\begin{array}{l}1.0 \mathrm{E}-1 \\
{[0.00]}\end{array}$ \\
\hline & 10 & $\begin{array}{l}5.3 \mathrm{E}+2 \\
{[0.26]}\end{array}$ & $\begin{array}{c}4.0 \mathrm{E}+1 \\
{[0.00]}\end{array}$ & $\begin{array}{c}4.4 \mathrm{E}+1 \\
{[0.11]}\end{array}$ & $\begin{array}{c}1.6 \mathrm{E}+1 \\
{[0.01]}\end{array}$ & $\begin{array}{c}1.1 \mathrm{E}+1 \\
{[0.00]}\end{array}$ & $\begin{array}{c}5.1 \mathrm{E}-4 \\
{[0.00]}\end{array}$ & $\begin{array}{r}1.2 \mathrm{E}+2 \\
{[0.18]}\end{array}$ & $\begin{array}{l}1.0 \mathrm{E}-1 \\
{[0.00]}\end{array}$ \\
\hline & 5 & $\begin{array}{l}9.7 \mathrm{E}+2 \\
{[0.24]}\end{array}$ & $\begin{array}{c}2.2 \mathrm{E}+1 \\
{[0.00]}\end{array}$ & $\begin{array}{c}7.7 \mathrm{E}+1 \\
{[0.10]}\end{array}$ & $\begin{array}{c}2.8 \mathrm{E}+1 \\
{[0.01]}\end{array}$ & $\begin{array}{c}1.7 \mathrm{E}+1 \\
{[0.00]}\end{array}$ & $\begin{array}{c}\text { ND } \\
{[0.00]}\end{array}$ & $\begin{array}{l}2.4 \mathrm{E}+2 \\
{[0.18]}\end{array}$ & $\begin{array}{l}4.1 \mathrm{E}-1 \\
{[0.00]}\end{array}$ \\
\hline & 5 & $\begin{array}{l}9.7 \mathrm{E}+2 \\
{[0.24]}\end{array}$ & $\begin{array}{c}2.2 \mathrm{E}+1 \\
{[0.00]}\end{array}$ & $\begin{array}{c}7.7 \mathrm{E}+1 \\
{[0.10]}\end{array}$ & $\begin{array}{c}2.9 \mathrm{E}+1 \\
{[0.01]}\end{array}$ & $\begin{array}{c}1.7 \mathrm{E}+1 \\
{[0.00]}\end{array}$ & $\begin{array}{c}\text { ND } \\
{[0.00]}\end{array}$ & $\begin{array}{l}2.3 \mathrm{E}+2 \\
{[0.17]}\end{array}$ & $\begin{array}{l}4.2 \mathrm{E}-1 \\
{[0.00]}\end{array}$ \\
\hline & 2 & $\begin{array}{l}1.9 \mathrm{E}+3 \\
{[0.19]}\end{array}$ & $\begin{array}{c}1.8 \mathrm{E}+1 \\
{[0.00]}\end{array}$ & $\begin{array}{c}1.4 \mathrm{E}+2 \\
{[0.07]}\end{array}$ & $\begin{array}{c}5.0 \mathrm{E}+1 \\
{[0.00]}\end{array}$ & $\begin{array}{c}2.9 \mathrm{E}+1 \\
{[0.00]}\end{array}$ & $\begin{array}{c}8.2 \mathrm{E}-2 \\
{[0.00]}\end{array}$ & $\begin{array}{l}6.4 \mathrm{E}+2 \\
{[0.19]}\end{array}$ & $\begin{array}{l}1.6 \mathrm{E}+0 \\
{[0.00]}\end{array}$ \\
\hline & 2 & $\begin{array}{c}2.0 \mathrm{E}+3 \\
{[0.20]}\end{array}$ & $\begin{array}{c}1.5 \mathrm{E}+1 \\
{[0.00]}\end{array}$ & $\begin{array}{c}1.4 \mathrm{E}+2 \\
{[0.07]}\end{array}$ & $\begin{array}{c}4.9 \mathrm{E}+1 \\
{[0.00]}\end{array}$ & $\begin{array}{c}2.8 \mathrm{E}+1 \\
{[0.00]}\end{array}$ & $\begin{array}{c}\text { ND } \\
{[0.00]}\end{array}$ & $\begin{array}{l}6.4 \mathrm{E}+2 \\
{[0.19]}\end{array}$ & $\begin{array}{l}1.6 \mathrm{E}+0 \\
{[0.00]}\end{array}$ \\
\hline
\end{tabular}


Table 5.9. (contd)

\begin{tabular}{|c|c|c|c|c|c|c|c|c|c|}
\hline Waste Forms & LS & $\begin{array}{c}\mathrm{Na} \\
(\mathrm{mg} / \mathrm{L})\end{array}$ & $\begin{array}{c}\mathrm{Ca} \\
(\mathrm{mg} / \mathrm{L})\end{array}$ & $\begin{array}{c}\mathrm{K} \\
(\mathrm{mg} / \mathrm{L})\end{array}$ & $\begin{array}{c}\mathrm{Al} \\
(\mathrm{mg} / \mathrm{L})\end{array}$ & $\begin{array}{c}\mathrm{Si} \\
(\mathrm{mg} / \mathrm{L})\end{array}$ & $\begin{array}{c}\mathrm{Mg} \\
(\mathrm{mg} / \mathrm{L})\end{array}$ & $\begin{array}{c}\mathrm{S} \\
(\mathrm{mg} / \mathrm{L})\end{array}$ & $\begin{array}{c}\mathrm{Fe} \\
(\mathrm{mg} / \mathrm{L})\end{array}$ \\
\hline \multirow{6}{*}{$\begin{array}{c}\text { Geopolymer } \\
\text { Batch \#1 }\end{array}$} & 10 & $\begin{array}{l}4.8 \mathrm{E}+2 \\
{[0.25]}\end{array}$ & $\begin{array}{l}1.3 \mathrm{E}+0 \\
{[0.00]}\end{array}$ & $\begin{array}{c}9.7 \mathrm{E}+2 \\
{[0.12]}\end{array}$ & $\begin{array}{l}1.8 \mathrm{E}+1 \\
{[0.00]}\end{array}$ & $\begin{array}{c}3.5 \mathrm{E}+1 \\
{[0.00]}\end{array}$ & $\begin{array}{c}\mathrm{ND} \\
{[0.00]}\end{array}$ & $\begin{array}{l}2.6 \mathrm{E}+2 \\
{[1.38]}\end{array}$ & $\begin{array}{c}\mathrm{ND} \\
{[0.00]}\end{array}$ \\
\hline & 10 & $\begin{array}{l}5.0 \mathrm{E}+2 \\
{[0.26]}\end{array}$ & $\begin{array}{c}3.5 \mathrm{E}+0 \\
{[0.00]}\end{array}$ & $\begin{array}{l}1.0 \mathrm{E}+3 \\
{[0.12]}\end{array}$ & $\begin{array}{c}1.8 \mathrm{E}+1 \\
{[0.00]}\end{array}$ & $\begin{array}{c}3.7 \mathrm{E}+1 \\
{[0.00]}\end{array}$ & $\begin{array}{l}5.5 \mathrm{E}-2 \\
{[0.00]}\end{array}$ & $\begin{array}{l}2.6 \mathrm{E}+2 \\
{[1.38]}\end{array}$ & $\begin{array}{c}\mathrm{ND} \\
{[0.00]}\end{array}$ \\
\hline & 5 & $\begin{array}{l}8.8 \mathrm{E}+2 \\
{[0.23]}\end{array}$ & $\begin{array}{l}2.2 \mathrm{E}+0 \\
{[0.00]}\end{array}$ & $\begin{array}{l}1.8 \mathrm{E}+3 \\
{[0.11]}\end{array}$ & $\begin{array}{c}1.9 \mathrm{E}+1 \\
{[0.00]}\end{array}$ & $\begin{array}{c}5.2 \mathrm{E}+1 \\
{[0.00]}\end{array}$ & $\begin{array}{l}2.9 \mathrm{E}-2 \\
{[0.00]}\end{array}$ & $\begin{array}{l}6.1 \mathrm{E}+2 \\
{[1.62]}\end{array}$ & $\begin{array}{c}\mathrm{ND} \\
{[0.00]}\end{array}$ \\
\hline & 5 & $\begin{array}{l}8.4 \mathrm{E}+2 \\
{[0.22]}\end{array}$ & $\begin{array}{l}2.2 \mathrm{E}+0 \\
{[0.00]}\end{array}$ & $\begin{array}{c}1.7 \mathrm{E}+3 \\
{[0.10]}\end{array}$ & $\begin{array}{l}1.9 \mathrm{E}+1 \\
{[0.00]}\end{array}$ & $\begin{array}{c}5.0 \mathrm{E}+1 \\
{[0.00]}\end{array}$ & $\begin{array}{l}3.4 \mathrm{E}-2 \\
{[0.00]}\end{array}$ & $\begin{array}{l}5.7 \mathrm{E}+2 \\
{[1.52]}\end{array}$ & $\begin{array}{l}4.8 \mathrm{E}-3 \\
{[0.00]}\end{array}$ \\
\hline & 2 & $\begin{array}{l}1.8 \mathrm{E}+3 \\
{[0.19]}\end{array}$ & $\begin{array}{c}3.9 \mathrm{E}+0 \\
{[0.00]}\end{array}$ & $\begin{array}{c}3.5 \mathrm{E}+3 \\
{[0.08]}\end{array}$ & $\begin{array}{c}1.8 \mathrm{E}+1 \\
{[0.00]}\end{array}$ & $\begin{array}{c}8.7 \mathrm{E}+1 \\
{[0.00]}\end{array}$ & $\begin{array}{l}2.8 \mathrm{E}-2 \\
{[0.00]}\end{array}$ & $\begin{array}{l}1.4 \mathrm{E}+3 \\
{[1.49]}\end{array}$ & $\begin{array}{l}1.5 \mathrm{E}-2 \\
{[0.00]}\end{array}$ \\
\hline & 2 & $\begin{array}{l}1.7 \mathrm{E}+3 \\
{[0.18]}\end{array}$ & $\begin{array}{l}3.9 \mathrm{E}+0 \\
{[0.00]}\end{array}$ & $\begin{array}{c}3.5 \mathrm{E}+3 \\
{[0.08]}\end{array}$ & $\begin{array}{l}1.8 \mathrm{E}+1 \\
{[0.00]}\end{array}$ & $8.8 \mathrm{E}+1$ & $\begin{array}{l}1.3 \mathrm{E}-2 \\
{[0.00]}\end{array}$ & $\begin{array}{l}1.3 \mathrm{E}+3 \\
{[1.38]}\end{array}$ & $\begin{array}{c}\text { ND } \\
{[0.00]}\end{array}$ \\
\hline \multirow{6}{*}{$\begin{array}{c}\text { Geopolymer } \\
\text { Batch } \# 2\end{array}$} & 10 & $\begin{array}{l}4.8 \mathrm{E}+2 \\
{[0.27]}\end{array}$ & $\begin{array}{l}8.7 \mathrm{E}-1 \\
{[0.00]}\end{array}$ & $\begin{array}{c}8.7 \mathrm{E}+2 \\
{[0.11]}\end{array}$ & $\begin{array}{c}1.1 \mathrm{E}+1 \\
{[0.00]}\end{array}$ & $\begin{array}{c}3.9 \mathrm{E}+1 \\
{[0.00]}\end{array}$ & $\begin{array}{c}\text { ND } \\
{[0.00]}\end{array}$ & $\begin{array}{l}2.7 \mathrm{E}+2 \\
{[1.43]}\end{array}$ & $\begin{array}{c}\mathrm{ND} \\
{[0.00]}\end{array}$ \\
\hline & 10 & $\begin{array}{l}4.8 \mathrm{E}+2 \\
{[0.27]}\end{array}$ & $\begin{array}{l}1.2 \mathrm{E}+0 \\
{[0.00]}\end{array}$ & $\begin{array}{c}8.7 \mathrm{E}+2 \\
{[0.11]}\end{array}$ & $\begin{array}{l}1.0 \mathrm{E}+1 \\
{[0.00]}\end{array}$ & $\begin{array}{c}3.8 \mathrm{E}+1 \\
{[0.00]}\end{array}$ & $\begin{array}{l}6.2 \mathrm{E}-3 \\
{[0.00]}\end{array}$ & $\begin{array}{l}2.8 \mathrm{E}+2 \\
{[1.48]}\end{array}$ & $\begin{array}{c}\text { ND } \\
{[0.00]}\end{array}$ \\
\hline & 5 & $\begin{array}{l}7.6 \mathrm{E}+2 \\
{[0.21]}\end{array}$ & $\begin{array}{c}2.1 \mathrm{E}+0 \\
{[0.00]}\end{array}$ & $\begin{array}{c}1.4 \mathrm{E}+3 \\
{[0.09]}\end{array}$ & $\begin{array}{c}8.4 \mathrm{E}+0 \\
{[0.00]}\end{array}$ & $\begin{array}{c}4.5 \mathrm{E}+1 \\
{[0.00]}\end{array}$ & $\begin{array}{l}4.8 \mathrm{E}-2 \\
{[0.00]}\end{array}$ & $\begin{array}{l}3.3 \mathrm{E}+2 \\
{[0.87]}\end{array}$ & $\begin{array}{l}1.3 \mathrm{E}-2 \\
{[0.00]}\end{array}$ \\
\hline & 5 & $\begin{array}{l}7.4 \mathrm{E}+2 \\
{[0.21]}\end{array}$ & $\begin{array}{c}2.0 \mathrm{E}+0 \\
{[0.00]}\end{array}$ & $\begin{array}{l}1.4 \mathrm{E}+3 \\
{[0.09]}\end{array}$ & $\begin{array}{c}8.8 \mathrm{E}+0 \\
{[0.00]}\end{array}$ & $\begin{array}{c}4.7 \mathrm{E}+1 \\
{[0.00]}\end{array}$ & $\begin{array}{l}4.7 \mathrm{E}-2 \\
{[0.00]}\end{array}$ & $\begin{array}{l}2.9 \mathrm{E}+2 \\
{[0.77]}\end{array}$ & $\begin{array}{l}6.0 \mathrm{E}-3 \\
{[0.00]}\end{array}$ \\
\hline & 2 & $\begin{array}{l}1.5 \mathrm{E}+3 \\
{[0.17]}\end{array}$ & $\begin{array}{l}3.2 \mathrm{E}+0 \\
{[0.00]}\end{array}$ & $\begin{array}{c}2.9 \mathrm{E}+3 \\
{[0.07]}\end{array}$ & $\begin{array}{l}7.9 \mathrm{E}+0 \\
{[0.00]}\end{array}$ & $\begin{array}{c}6.4 \mathrm{E}+1 \\
{[0.00]}\end{array}$ & $\begin{array}{l}7.2 \mathrm{E}-2 \\
{[0.00]}\end{array}$ & $\begin{array}{l}1.1 \mathrm{E}+3 \\
{[1.16]}\end{array}$ & $\begin{array}{l}6.3 \mathrm{E}-2 \\
{[0.00]}\end{array}$ \\
\hline & 2 & $\begin{array}{l}1.5 \mathrm{E}+3 \\
{[0.17]}\end{array}$ & $\begin{array}{c}3.2 \mathrm{E}+0 \\
{[0.00]}\end{array}$ & $\begin{array}{c}2.9 \mathrm{E}+3 \\
{[0.07]}\end{array}$ & $\begin{array}{l}7.9 \mathrm{E}+0 \\
{[0.00]}\end{array}$ & $\begin{array}{c}6.3 \mathrm{E}+1 \\
{[0.00]}\end{array}$ & $\begin{array}{l}6.0 \mathrm{E}-2 \\
{[0.00]}\end{array}$ & $\begin{array}{l}9.7 \mathrm{E}+2 \\
{[1.03]}\end{array}$ & $\begin{array}{l}3.9 \mathrm{E}-2 \\
{[0.00]}\end{array}$ \\
\hline
\end{tabular}

(a) Percentage of leaching (\%) is also shown in bracket, [ ], below measured concentrations (mg/L). ND indicates "not detected" and below quantification level for $\mathrm{Al}(<6.3 \mathrm{E}-4 \mathrm{mg} / \mathrm{L})$; $\mathrm{Mg}(<3.3 \mathrm{E}-4 \mathrm{mg} / \mathrm{L})$; $\mathrm{Fe}(<7.0 \mathrm{E}-4 \mathrm{mg} / \mathrm{L})$. 
Table 5.10. The Concentrations of RCRA Metals in Eluate for Waste Forms from 1316 Method $^{(a)}$

\begin{tabular}{|c|c|c|c|c|c|c|}
\hline Waste Forms & LS & $\begin{array}{c}\mathrm{Cd} \\
(\mu \mathrm{g} / \mathrm{L})\end{array}$ & $\begin{array}{c}\mathrm{Cr} \\
(\mu \mathrm{g} / \mathrm{L})\end{array}$ & $\begin{array}{c}\mathrm{Pb} \\
(\mu \mathrm{g} / \mathrm{L})\end{array}$ & $\begin{array}{c}\mathrm{Ag} \\
(\mu \mathrm{g} / \mathrm{L})\end{array}$ & $\begin{array}{c}\mathrm{Hg} \\
(\mu \mathrm{g} / \mathrm{L})\end{array}$ \\
\hline \multirow{6}{*}{ Cast Stone } & 10 & $\begin{array}{l}\mathrm{ND}^{(\mathrm{b})} \\
{[0.00]}\end{array}$ & $\begin{array}{l}28.0 \\
{[0.75]}\end{array}$ & $\begin{array}{c}\mathrm{ND} \\
{[0.00]}\end{array}$ & $\begin{array}{c}2.53 \\
{[0.80]}\end{array}$ & $\begin{array}{c}11.4 \\
{[30.0]}\end{array}$ \\
\hline & 10 & $\begin{array}{c}\text { ND } \\
{[0.00]}\end{array}$ & $\begin{array}{l}31.1 \\
{[0.83]}\end{array}$ & $\begin{array}{c}\text { ND } \\
{[0.00]}\end{array}$ & $\begin{array}{c}1.75 \\
{[0.56]}\end{array}$ & $\begin{array}{c}13.0 \\
{[33.9]}\end{array}$ \\
\hline & 5 & $\begin{array}{l}16.0 \\
{[0.63]}\end{array}$ & $\begin{array}{l}27.0 \\
{[0.36]}\end{array}$ & $\begin{array}{c}\text { ND } \\
{[0.00]}\end{array}$ & $\begin{array}{c}5.78 \\
{[0.92]}\end{array}$ & $\begin{array}{c}20.7 \\
{[27.0]}\end{array}$ \\
\hline & 5 & $\begin{array}{l}16.2 \\
{[0.64]}\end{array}$ & $\begin{array}{l}36.4 \\
{[0.49]}\end{array}$ & $\begin{array}{l}0.227 \\
\quad[0.00]\end{array}$ & $\begin{array}{c}6.30 \\
{[1.00]}\end{array}$ & $\begin{array}{c}21.3 \\
{[27.9]}\end{array}$ \\
\hline & 2 & $\begin{array}{l}28.4 \\
{[0.45]}\end{array}$ & $\begin{array}{l}60.1 \\
{[0.32]}\end{array}$ & $\begin{array}{l}5.67 \\
{[0.02]}\end{array}$ & $\begin{array}{c}8.20 \\
{[0.52]}\end{array}$ & $\begin{array}{c}58.4 \\
{[30.5]}\end{array}$ \\
\hline & 2 & $\begin{array}{l}29.5 \\
{[0.46]}\end{array}$ & $\begin{array}{l}42.5 \\
{[0.23]}\end{array}$ & $\begin{array}{l}6.24 \\
\quad[0.03]\end{array}$ & $\begin{array}{c}8.92 \\
{[0.57]}\end{array}$ & $\begin{array}{c}59.8 \\
{[31.2]}\end{array}$ \\
\hline \multirow{6}{*}{$\begin{array}{c}\text { Geopolymer } \\
\text { Batch \#1 }\end{array}$} & 10 & $\begin{array}{c}\text { ND } \\
{[0.00]}\end{array}$ & $\begin{array}{l}38.5 \\
{[1.49]}\end{array}$ & $\begin{array}{c}\text { ND } \\
{[0.00]}\end{array}$ & $\begin{array}{c}2.50 \\
{[0.00]}\end{array}$ & $\begin{array}{c}66.4 \\
{[35.0]}\end{array}$ \\
\hline & 10 & $\begin{array}{c}\text { ND } \\
{[0.00]}\end{array}$ & $\begin{array}{l}45.0 \\
{[1.74]}\end{array}$ & $\begin{array}{l}\text { ND } \\
{[0.00]}\end{array}$ & $\begin{array}{c}2.79 \\
{[0.00]}\end{array}$ & $\begin{array}{c}68.9 \\
{[36.3]}\end{array}$ \\
\hline & 5 & $\begin{array}{c}\text { ND } \\
{[0.00]}\end{array}$ & $\begin{array}{c}3.71 \\
{[0.07]}\end{array}$ & $\begin{array}{c}\text { ND } \\
{[0.00]}\end{array}$ & $\begin{array}{c}5.57 \\
{[0.00]}\end{array}$ & $\begin{array}{c}57.2 \\
{[15.1]}\end{array}$ \\
\hline & 5 & $\begin{array}{c}\mathrm{ND} \\
{[0.00]}\end{array}$ & $\begin{array}{c}8.60 \\
{[0.17]}\end{array}$ & $\begin{array}{c}\mathrm{ND} \\
{[0.00]}\end{array}$ & $\begin{array}{c}9.31 \\
{[0.00]}\end{array}$ & $\begin{array}{c}55.7 \\
{[14.7]}\end{array}$ \\
\hline & 2 & $\begin{array}{c}\text { ND } \\
{[0.00]}\end{array}$ & $\begin{array}{c}9.96 \\
{[0.08]}\end{array}$ & $\begin{array}{c}\mathrm{ND} \\
{[0.00]}\end{array}$ & $\begin{array}{c}5.55 \\
{[0.00]}\end{array}$ & $\begin{array}{l}136 \\
{[14.3]}\end{array}$ \\
\hline & 2 & $\begin{array}{c}\text { ND } \\
{[0.00]}\end{array}$ & $\begin{array}{c}6.34 \\
{[0.05]}\end{array}$ & $\begin{array}{c}\text { ND } \\
{[0.00]}\end{array}$ & $\begin{array}{c}5.91 \\
{[0.00]}\end{array}$ & $\begin{array}{l}125 \\
{[13.2]}\end{array}$ \\
\hline \multirow{6}{*}{$\begin{array}{c}\text { Geopolymer } \\
\text { Batch \#2 }\end{array}$} & 10 & $\begin{array}{c}\text { ND } \\
{[0.00]}\end{array}$ & $\begin{array}{l}59.0 \\
{[2.07]}\end{array}$ & $\begin{array}{c}\text { ND } \\
{[0.00]}\end{array}$ & $\begin{array}{c}4.41 \\
{[0.01]}\end{array}$ & $\begin{array}{l}12.5 \\
{[4.15]}\end{array}$ \\
\hline & 10 & $\begin{array}{c}\text { ND } \\
{[0.00]}\end{array}$ & $\begin{array}{l}38.0 \\
{[1.33]}\end{array}$ & $\begin{array}{l}\text { ND } \\
{[0.00]}\end{array}$ & $\begin{array}{c}5.74 \\
{[0.01]}\end{array}$ & $\begin{array}{l}14.0 \\
{[4.65]}\end{array}$ \\
\hline & 5 & $\begin{array}{c}6.67 \\
{[1.81]}\end{array}$ & $\begin{array}{l}124 \\
{[2.18]}\end{array}$ & $\begin{array}{c}6.84 \\
{[0.07]}\end{array}$ & $\begin{array}{c}4.05 \\
{[0.00]}\end{array}$ & $\begin{array}{l}44.3 \\
{[7.36]}\end{array}$ \\
\hline & 5 & $\begin{array}{c}5.64 \\
{[1.53]}\end{array}$ & $\begin{array}{l}118 \\
{[2.07]}\end{array}$ & $\begin{array}{c}1.40 \\
{[0.01]}\end{array}$ & $\begin{array}{c}3.64 \\
{[0.00]}\end{array}$ & $\begin{array}{l}41.8 \\
{[6.94]}\end{array}$ \\
\hline & 2 & $\begin{array}{c}5.53 \\
{[0.60]}\end{array}$ & $\begin{array}{l}289 \\
{[2.03]}\end{array}$ & $\begin{array}{c}1.55 \\
{[0.01]}\end{array}$ & $\begin{array}{c}3.67 \\
{[0.00]}\end{array}$ & $\begin{array}{l}116 \\
{[7.71]}\end{array}$ \\
\hline & 2 & $\begin{array}{c}3.89 \\
{[0.42]}\end{array}$ & $\begin{array}{l}275 \\
{[1.93]}\end{array}$ & $\begin{array}{c}1.64 \\
{[0.01]}\end{array}$ & $\begin{array}{c}3.59 \\
{[0.00]}\end{array}$ & $\begin{array}{l}113 \\
{[7.51]}\end{array}$ \\
\hline
\end{tabular}

(a) Percentage of leaching (\%) is also shown in bracket, [ ], below measured concentrations $(\mu \mathrm{g} / \mathrm{L})$.

(b) ND indicates "not detected" and below quantification level for As $(<5.7 \mathrm{E}-2 \mu \mathrm{g} / \mathrm{L})$; Cd $(<1.1 \mathrm{E}-2 \mu \mathrm{g} / \mathrm{L})$; Cr $(<6.9 \mathrm{E}-2 \mu \mathrm{g} / \mathrm{L})$; $\mathrm{Pb}(<2.7 \mathrm{E}-2$ $\mu \mathrm{g} / \mathrm{L})$; $\mathrm{Se}(<1.6 \mathrm{E}-1 \mu \mathrm{g} / \mathrm{L}) ; \mathrm{Hg}(<3.6 \mathrm{E}-4 \mu \mathrm{g} / \mathrm{L}) ; \mathrm{Cu}(<2.5 \mathrm{E}-1 \mu \mathrm{g} / \mathrm{L})$. 
Table 5.11. The Concentrations of Major Anions, ${ }^{99} \mathrm{Tc}$, and ${ }^{127} \mathrm{I}$ in Eluate for Waste Forms from 1316 Method

\begin{tabular}{|c|c|c|c|c|c|c|c|c|}
\hline Waste Forms & LS & $\begin{array}{c}\mathrm{NO}_{3}^{-} \\
(\mathrm{mg} / \mathrm{L})\end{array}$ & $\begin{array}{l}\mathrm{PO}_{4}^{3-} \\
(\mathrm{mg} / \mathrm{L})\end{array}$ & $\begin{array}{c}\mathrm{PO}_{4}^{3-} \\
(\mathrm{mg} / \mathrm{L})^{(\mathrm{a})}\end{array}$ & $\begin{array}{l}\mathrm{SO}_{4}{ }^{2-} \\
(\mathrm{mg} / \mathrm{L})\end{array}$ & $\begin{array}{c}\mathrm{SO}_{4}^{2} \\
(\mathrm{mg} / \mathrm{L})^{(\mathrm{a})}\end{array}$ & ${ }^{99} \mathrm{Tc}(\mu \mathrm{g} / \mathrm{L})$ & $\begin{array}{c}{ }^{127} \mathrm{I} \\
(\mu \mathrm{g} / \mathrm{L})\end{array}$ \\
\hline \multirow{6}{*}{ Cast Stone } & 10 & 150 & $\mathrm{ND}^{(\mathrm{b})}$ & ND & 144 & 362 & $\begin{array}{l}3.40 \\
{[21.3]^{(\mathrm{c})}}\end{array}$ & $\begin{array}{c}2.96 \\
{[<5.15]^{(\mathrm{c})}}\end{array}$ \\
\hline & 10 & 169.2 & ND & ND & 138 & 359 & $\begin{array}{l}3.66 \\
{[22.9]}\end{array}$ & $\begin{array}{c}4.70 \\
{[<8.17]}\end{array}$ \\
\hline & 5 & 289.1 & ND & 0.443 & 258 & 690 & $\begin{array}{l}6.43 \\
{[20.1]}\end{array}$ & $\begin{array}{l}25.5 \\
\quad[<22.2]\end{array}$ \\
\hline & 5 & 289.2 & ND & 0.158 & 252 & 705 & $\begin{array}{l}6.52 \\
{[20.4]}\end{array}$ & $\begin{array}{l}17.1 \\
{[<14.9]}\end{array}$ \\
\hline & 2 & 739 & ND & 0.478 & 550 & 1904 & $\begin{array}{l}15.7 \\
{[19.6]}\end{array}$ & $\begin{array}{l}68.6 \\
{[<23.9]}\end{array}$ \\
\hline & 2 & 763 & ND & 0.288 & 555 & 1906 & $\begin{array}{l}15.3 \\
{[19.1]}\end{array}$ & $\begin{array}{l}66.5 \\
{[<23.1]}\end{array}$ \\
\hline \multirow{6}{*}{$\begin{array}{c}\text { Geopolymer } \\
\text { Batch \#1 }\end{array}$} & 10 & 625 & ND & 2.48 & 177 & 765 & $\begin{array}{l}8.77 \\
{[29.1]}\end{array}$ & $\begin{array}{l}28.9 \\
\quad[<58.2]\end{array}$ \\
\hline & 10 & 646 & ND & 2.42 & 188 & 778 & $\begin{array}{l}9.32 \\
{[31.0]}\end{array}$ & $\begin{array}{l}29.9 \\
\quad[<60.1]\end{array}$ \\
\hline & 5 & 1312 & ND & 1.96 & 252 & 1722 & $\begin{array}{l}17.69 \\
{[29.4]}\end{array}$ & $\begin{array}{l}64.2 \\
{[<64.6]}\end{array}$ \\
\hline & 5 & 1310 & ND & 1.96 & 252 & 1827 & $\begin{array}{l}17.86 \\
{[29.7]}\end{array}$ & $\begin{array}{l}62.9 \\
{[<63.3]}\end{array}$ \\
\hline & 2 & 3387 & ND & 2.42 & 652 & 4284 & $\begin{array}{l}38.22 \\
{[25.4]}\end{array}$ & $\begin{array}{l}184 \\
{[<74.0]}\end{array}$ \\
\hline & 2 & 3370 & ND & 2.48 & 651 & 4023 & $\begin{array}{l}35.93 \\
{[23.9]}\end{array}$ & $\begin{array}{l}184 \\
{[<74.0]}\end{array}$ \\
\hline \multirow{6}{*}{$\begin{array}{c}\text { Geopolymer } \\
\text { Batch \#2 }\end{array}$} & 10 & 641 & 2.51 & 1.43 & 142 & 819 & $\begin{array}{l}2.97 \\
{[13.0]}\end{array}$ & $\begin{array}{l}25.8 \\
{[<39.2]}\end{array}$ \\
\hline & 10 & 645 & ND & 1.16 & 144 & 829 & $\begin{array}{l}2.95 \\
{[12.9]}\end{array}$ & $\begin{array}{l}27.1 \\
{[<41.1]}\end{array}$ \\
\hline & 5 & 1263 & ND & 1.79 & 307 & 994 & $\begin{array}{l}8.52 \\
{[18.6]}\end{array}$ & $\begin{array}{l}56.8 \\
{[<43.1]}\end{array}$ \\
\hline & 5 & 1225 & ND & 1.34 & 298 & 875 & $\begin{array}{l}8.41 \\
{[18.4]}\end{array}$ & $\begin{array}{l}54.6 \\
{[<41.4]}\end{array}$ \\
\hline & 2 & 3337 & ND & 2.03 & 807 & 2901 & $\begin{array}{l}21.9 \\
{[19.1]}\end{array}$ & $\begin{array}{l}152 \\
{[<46.1]}\end{array}$ \\
\hline & 2 & 3341 & ND & 1.93 & 809 & 3393 & $\begin{array}{l}19.2 \\
{[16.8]}\end{array}$ & $\begin{array}{l}160 \\
{[<48.6]}\end{array}$ \\
\hline
\end{tabular}

(a) $\mathrm{PO}_{4}{ }^{3-}$ and $\mathrm{SO}_{4}{ }^{2-}$ were also calculated based on phosphorus and sulfur concentrations analyzed by ICP-OES.

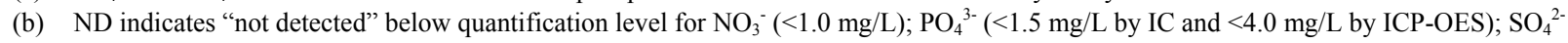
$(<1.5 \mathrm{mg} / \mathrm{L}$ by IC).

(c) Percentage of leaching (\%) is also shown in bracket, [ ], below measured concentrations (mg/L). Because of low concentration of spiked iodine, leaching percentage of iodide was calculated based on the instrumental MDL (See Tables 5.1 and 5.3). 


\subsection{EPA Method 1315}

For Method 1315, monoliths of the three waste forms were suspended in DI water at a liquid volumeto-specimen surface area of $9 \pm 1 \mathrm{~mL}$ per $\mathrm{cm}^{2}$. The leaching solutions were renewed at the specified time intervals, and the results for the $\mathrm{pH}, \mathrm{EC}$, Eh and alkalinity for each waste form are displayed in Table 5.12. The $\mathrm{pH}$ levels for all three waste forms were between 10 and 12, demonstrating an initial increasing trend that became relatively steady as the sample contact time increased, suggesting equilibrium conditions may have been achieved at the longer contact times. Slightly lower pHs ( 11) were measured for the three waste forms after one day's reaction in the 1315 Method, compared to those from the 1313 and 1316 methods ( $\mathrm{pH} \sim 12-13$ ). The observed lower $\mathrm{pH}$ values resulted from the larger volume-tospecimen surface area used in the 1315 Method as well as the fact that monoliths dissolve much more slowly than crushed samples. The Eh values initially decreased and then increased to a steady-state value as the sample contact time increased. The EC and alkalinity values for the Cast Stone leachate solutions were much lower in comparison to the Geopolymer solutions. For example, the EC values for the Geopolymer solutions were as much as four times greater than the values for the Cast Stone solutions, whereas the alkalinity for the Geopolymer solutions were between two to three times greater than the Cast Stone solutions at equivalent contact times. These qualitative assessments suggest that the Geopolymer samples are dissolving faster than the Cast Stone samples. This is somewhat consistent with visual observations of solution samples removed from the test. In the case of the Geopolymer samples, a small amount of solid has been observed accumulating in the bottom of the leaching vessels during sampling intervals. Solids were not observed in the bottom of the Cast Stone leaching vessels. Although a small of solid was observed for the Geopolymer samples, visual observations suggest the structural integrity of samples had not degraded to the same level that was observed in the study by Russell et al. (2006).

Table 5.12. pH, EC, Eh and Alkalinity Results for EPA Method 1315

\begin{tabular}{|c|c|c|c|c|c|c|}
\hline Waste Form & $\begin{array}{c}\text { Cumulative } \\
\text { Leach Time } \\
\text { (Days) }\end{array}$ & $\begin{array}{l}\text { Interval } \\
\text { label }\end{array}$ & $\mathrm{pH}$ & $\begin{array}{c}\mathrm{EC} \\
(\mathrm{mS} / \mathrm{cm})\end{array}$ & $\begin{array}{c}\text { Actual } \\
\text { Eh }(\mathrm{mV})^{(\mathrm{a})}\end{array}$ & $\begin{array}{c}\text { Alkalinity } \\
\left(\mathrm{mg} / \mathrm{L} \text { as } \mathrm{CaCO}_{3}\right)\end{array}$ \\
\hline \multirow{18}{*}{ Cast Stone } & 0.08 & T01 & 10.83 & 0.161 & $\mathrm{NM}^{(\mathrm{b})}$ & 51.9 \\
\hline & 0.08 & T01 & 10.84 & 0.153 & NM & 51.9 \\
\hline & 1 & T02 & 11.22 & 0.278 & 204.90 & 77.5 \\
\hline & 1 & T02 & 11.19 & 0.251 & 210.50 & 73.3 \\
\hline & 2 & T03 & 10.71 & 0.153 & 219.00 & 59.3 \\
\hline & 2 & T03 & 10.85 & 0.159 & 227.90 & 52.7 \\
\hline & 7 & T04 & 11.31 & 0.453 & 129.00 & 113 \\
\hline & 7 & T04 & 11.33 & 0.405 & 135.10 & 108 \\
\hline & 14 & T05 & 11.36 & 0.368 & 124.60 & 63.4 \\
\hline & 14 & T05 & 11.38 & 0.349 & 129.90 & 51.9 \\
\hline & 28 & T06 & 11.18 & 0.489 & 102.80 & 104 \\
\hline & 28 & T06 & 11.20 & 0.444 & 106.10 & 84.0 \\
\hline & 42 & T07 & 11.28 & 0.393 & 148.30 & 80.7 \\
\hline & 42 & T07 & 11.16 & 0.372 & 163.00 & 75.0 \\
\hline & 49 & T08 & 10.75 & 0.182 & 237.30 & 40.6 \\
\hline & 49 & T08 & 10.72 & 0.169 & 241.10 & 43.9 \\
\hline & 63 & T09 & 10.71 & 0.295 & 226.90 & 93.5 \\
\hline & 63 & T09 & 10.92 & 0.335 & 222.50 & 110 \\
\hline
\end{tabular}


Table 5.12. (contd)

\begin{tabular}{|c|c|c|c|c|c|c|}
\hline Waste Form & $\begin{array}{c}\text { Cumulative } \\
\text { Leach Time } \\
\text { (Days) }\end{array}$ & $\begin{array}{c}\text { Interval } \\
\text { label }\end{array}$ & $\mathrm{pH}$ & $\begin{array}{c}\mathrm{EC} \\
(\mathrm{mS} / \mathrm{cm})\end{array}$ & $\begin{array}{c}\text { Actual } \\
\text { Eh }(\mathrm{mV})^{(a)}\end{array}$ & $\begin{array}{c}\text { Alkalinity } \\
\left(\mathrm{mg} / \mathrm{L} \text { as } \mathrm{CaCO}_{3}\right)\end{array}$ \\
\hline \multirow{18}{*}{$\begin{array}{c}\text { Geopolymer } \\
\text { Batch \#1 }\end{array}$} & 0.08 & T01 & 10.74 & 0.382 & 258.90 & 58.5 \\
\hline & 0.08 & T01 & 10.75 & 0.399 & 266.80 & 63.4 \\
\hline & 1 & T02 & 11.33 & 1.00 & 181.30 & 159 \\
\hline & 1 & T02 & 11.39 & 1.06 & 184.10 & 160 \\
\hline & 2 & $\mathrm{~T} 03$ & 11.41 & 0.784 & 107.00 & 112 \\
\hline & 2 & T03 & 11.47 & 0.845 & 99.00 & 122 \\
\hline & 7 & T04 & 11.86 & 2.26 & 50.20 & 276 \\
\hline & 7 & T04 & 11.94 & 2.32 & 57.30 & 312 \\
\hline & 14 & T05 & 11.65 & 2.11 & 103.30 & 288 \\
\hline & 14 & T05 & 11.64 & 2.23 & 117.70 & 295 \\
\hline & 28 & T06 & 11.81 & 2.38 & 176.10 & 381 \\
\hline & 28 & T06 & 11.56 & 1.89 & 184.20 & 295 \\
\hline & 42 & T07 & 11.64 & 1.58 & 178.80 & 282 \\
\hline & 42 & T07 & 11.71 & 1.62 & 176.30 & 294 \\
\hline & 49 & T08 & 11.13 & 0.683 & 212.60 & 152 \\
\hline & 49 & T08 & 11.18 & 0.686 & 208.10 & 159 \\
\hline & 63 & T09 & 11.42 & 0.861 & 201.30 & 181 \\
\hline & 63 & T09 & 11.44 & 0.893 & 210.40 & 198 \\
\hline \multirow{18}{*}{$\begin{array}{c}\text { Geopolymer } \\
\text { Batch \#2 }\end{array}$} & 0.08 & T01 & 10.36 & 0.196 & 153.80 & 47.8 \\
\hline & 0.08 & T01 & 10.59 & 0.253 & 159.30 & 56.0 \\
\hline & 1 & T02 & 11.16 & 0.927 & 147.90 & 105 \\
\hline & 1 & T02 & 11.15 & 0.930 & 153.60 & 113 \\
\hline & 2 & T03 & 10.96 & 0.657 & 160.10 & 81.6 \\
\hline & 2 & T03 & 10.92 & 0.656 & 162.50 & 87.3 \\
\hline & 7 & T04 & 11.40 & 1.96 & 144.90 & 222 \\
\hline & 7 & T04 & 11.42 & 2.03 & 144.60 & 228 \\
\hline & 14 & T05 & 11.51 & 1.70 & 128.00 & 216 \\
\hline & 14 & T05 & 11.50 & 1.73 & 140.80 & 222 \\
\hline & 28 & T06 & 11.81 & 2.31 & 184.90 & 394 \\
\hline & 28 & T06 & 11.59 & 1.92 & 190.50 & 296 \\
\hline & 42 & T07 & 11.39 & 1.32 & 196.00 & 228 \\
\hline & 42 & T07 & 11.39 & 1.35 & 189.00 & 250 \\
\hline & 49 & T08 & 11.00 & 0.469 & 202.60 & 130 \\
\hline & 49 & T08 & 11.11 & 0.525 & 200.60 & 131 \\
\hline & 63 & T09 & 11.31 & 0.740 & 135.40 & 173 \\
\hline & 63 & T09 & 11.37 & 0.780 & 139.60 & 174 \\
\hline
\end{tabular}

(a) Measured $\mathrm{Eh}$ is the value measure using an ORP probe. The actual $\mathrm{Eh}=$ Measured $\mathrm{Eh}+208 \mathrm{mV}$.

(b) NM-not measured

The diffusivity of ${ }^{99} \mathrm{Tc}$ for all three waste forms was calculated, and the results are displayed in Figure 5.17. The ${ }^{99} \mathrm{Tc}$ diffusivity values for the Cast Stone were typically 1 to 2 orders of magnitude lower than the diffusivity values calculated for Geopolymers. All three waste forms showed a slightly decreasing 
trend in calculated diffusivity as the contact time increased. Diffusivity values for the Cast Stone samples ranged between $9.1 \times 10^{-13} \mathrm{~cm}^{2} / \mathrm{s}$ at a cumulative leaching time of 2 days to $1.2 \times 10^{-11} \mathrm{~cm}^{2} / \mathrm{s}$ at a cumulative leaching time of 0.08 days. For the Geopolymer batch \#1, the diffusivity values ranged from $3.8 \times 10^{-12} \mathrm{~cm}^{2} / \mathrm{s}$ at cumulative leaching times of 63 days to $1.7 \times 10^{-10} \mathrm{~cm}^{2} / \mathrm{s}$ at 0.08 day cumulative leaching time. Geopolymer batch 2 diffusivity values ranged from $1.8 \times 10^{-11} \mathrm{~cm}^{2} / \mathrm{s}$ at cumulative leaching time 42 days to $1.2 \times 10^{-9} \mathrm{~cm}^{2} / \mathrm{s}$ at 7 day cumulative leaching time.

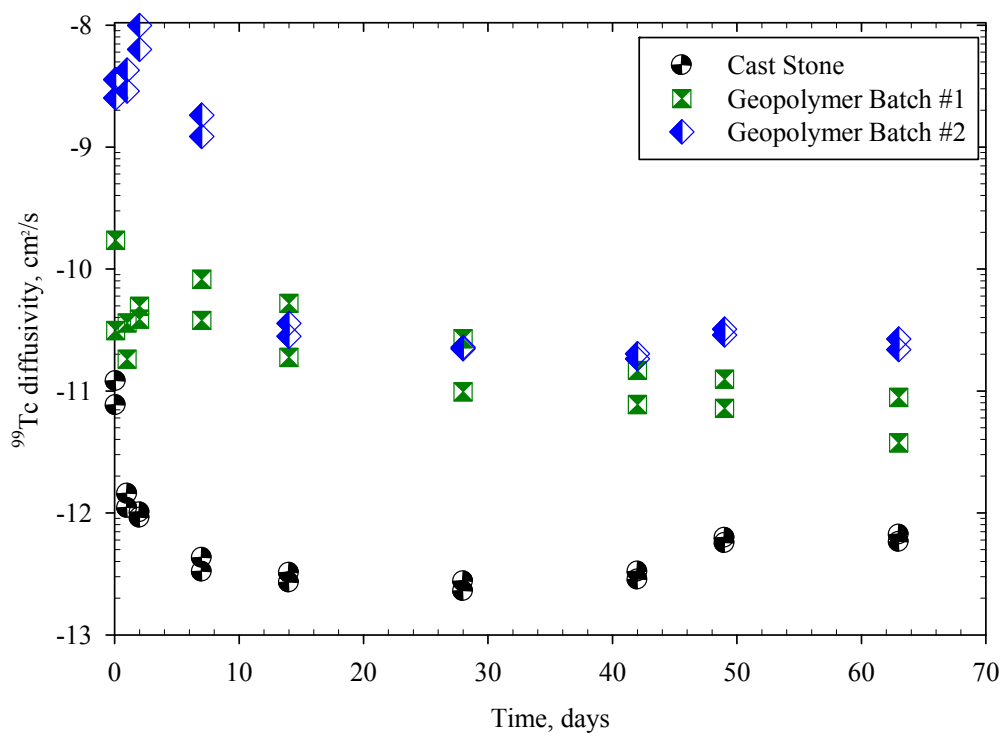

Figure 5.17. Diffusivity of ${ }^{99} \mathrm{Tc}$ for EPA Method 1315

The measured cation results are shown in Table 5.13 and suggest a steady release of these cations with an increase in time for each waste form. The RCRA metal results are shown in Table 5.14. In general, the concentration of silver, arsenic, cadmium, mercury, lead, and copper were below the detection limit for all the Cast Stone samples, while the Geopolymer batch \#1 samples had measureable amounts of arsenic, silver, mercury, and copper. Chromium release was observed in both Geopolymer batch \#1 and batch \#2 samples. The dominant anions present in the leachate solutions for both waste forms are displayed in Table 5.15. These results suggest that carbonate (shown as alkalinity in Table 5.12 ) is the primary anion present in the Cast Stone leachates, with lesser amounts of sulfate and nitrate. The concentration of nitrate was only measurable in the first couple of leachate samples. Unlike Cast Stone, leachates from Geopolymer batch \#1 and \#2 contained a significant concentration of nitrate (dominant anion) with lesser amounts of carbonate and sulfate. 
Table 5.13. The Concentrations of Major Cations in Eluate for Waste Forms from EPA Method 1315

\begin{tabular}{|c|c|c|c|c|c|c|c|c|c|}
\hline $\begin{array}{l}\text { Waste } \\
\text { Form }\end{array}$ & $\begin{array}{l}\text { Cumul. } \\
\text { Leach } \\
\text { Time } \\
\text { (Days) }\end{array}$ & $\begin{array}{c}\mathrm{Na} \\
(\mathrm{mg} / \mathrm{L})\end{array}$ & $\begin{array}{c}\mathrm{Ca} \\
(\mathrm{mg} / \mathrm{L})\end{array}$ & $\begin{array}{c}\mathrm{K} \\
(\mathrm{mg} / \mathrm{L})\end{array}$ & $\begin{array}{c}\mathrm{Al} \\
(\mathrm{mg} / \mathrm{L})\end{array}$ & $\begin{array}{c}\mathrm{Mg} \\
(\mathrm{mg} / \mathrm{L})\end{array}$ & $\begin{array}{c}\mathrm{Si} \\
(\mathrm{mg} / \mathrm{L})\end{array}$ & $\begin{array}{c}\mathrm{S} \\
(\mathrm{mg} / \mathrm{L})\end{array}$ & $\begin{array}{c}\mathrm{Fe} \\
(\mathrm{mg} / \mathrm{L})\end{array}$ \\
\hline \multirow{18}{*}{ Cast Stone } & 0.08 & $\begin{array}{c}1.9 \mathrm{E}+01 \\
{[0.50]}\end{array}$ & $1.5 \mathrm{E}+00$ & $2.1 \mathrm{E}+00$ & 8.6E-01 & $\mathrm{ND}^{(\mathrm{a})}$ & ND & ND & ND \\
\hline & 0.08 & $\begin{array}{c}1.9 \mathrm{E}+01 \\
{[0.50]}\end{array}$ & $1.1 \mathrm{E}+00$ & $2.3 \mathrm{E}+00$ & $9.6 \mathrm{E}-01$ & ND & ND & ND & ND \\
\hline & 1 & $\begin{array}{c}1.2 \mathrm{E}+01 \\
{[0.31]}\end{array}$ & $1.7 \mathrm{E}+01$ & ND & $1.7 \mathrm{E}+00$ & 7.5E-02 & $2.1 \mathrm{E}+00$ & ND & ND \\
\hline & 1 & $\begin{array}{c}1.3 \mathrm{E}+01 \\
{[0.34]}\end{array}$ & $1.4 \mathrm{E}+01$ & ND & $1.8 \mathrm{E}+00$ & 8.7E-02 & $2.0 \mathrm{E}+00$ & ND & ND \\
\hline & 2 & $\begin{array}{c}5.3 \mathrm{E}+00 \\
{[0.14]}\end{array}$ & $1.4 \mathrm{E}+01$ & ND & $1.2 \mathrm{E}+00$ & $1.5 \mathrm{E}-01$ & $2.1 \mathrm{E}+00$ & ND & ND \\
\hline & 2 & $\begin{array}{c}5.5 \mathrm{E}+00 \\
{[0.14]}\end{array}$ & $1.2 \mathrm{E}+01$ & ND & $1.2 \mathrm{E}+00$ & $1.3 \mathrm{E}-01$ & $1.9 \mathrm{E}+00$ & ND & ND \\
\hline & 7 & $\begin{array}{c}1.4 \mathrm{E}+01 \\
{[0.37]}\end{array}$ & $2.8 \mathrm{E}+01$ & ND & $2.8 \mathrm{E}+00$ & $1.5 \mathrm{E}-01$ & $6.6 \mathrm{E}+00$ & $2.3 \mathrm{E}+00$ & ND \\
\hline & 7 & $\begin{array}{c}1.4 \mathrm{E}+01 \\
{[0.37]}\end{array}$ & $2.7 \mathrm{E}+01$ & ND & $2.9 \mathrm{E}+00$ & $1.7 \mathrm{E}-01$ & $6.1 \mathrm{E}+00$ & $2.0 \mathrm{E}+00$ & ND \\
\hline & 14 & $\begin{array}{c}1.2 \mathrm{E}+01 \\
{[0.33]}\end{array}$ & $2.7 \mathrm{E}+01$ & ND & $2.9 \mathrm{E}+00$ & 3.0E-01 & $6.8 \mathrm{E}+00$ & ND & $1.7 \mathrm{E}-01$ \\
\hline & 14 & $\begin{array}{c}1.2 \mathrm{E}+01 \\
{[0.31]}\end{array}$ & $2.6 \mathrm{E}+01$ & ND & $2.7 \mathrm{E}+00$ & $2.3 \mathrm{E}-01$ & $6.3 \mathrm{E}+00$ & ND & ND \\
\hline & 28 & $\begin{array}{c}1.5 \mathrm{E}+01 \\
{[0.41]}\end{array}$ & $3.0 \mathrm{E}+01$ & ND & $3.1 \mathrm{E}+00$ & $1.8 \mathrm{E}-01$ & $2.1 \mathrm{E}+01$ & ND & ND \\
\hline & 28 & $\begin{array}{c}1.5 \mathrm{E}+01 \\
{[0.38]}\end{array}$ & $2.9 \mathrm{E}+01$ & ND & $3.0 \mathrm{E}+00$ & $2.0 \mathrm{E}-01$ & $2.2 \mathrm{E}+01$ & ND & ND \\
\hline & 42 & $\begin{array}{c}1.1 \mathrm{E}+01 \\
{[0.28]}\end{array}$ & $2.4 \mathrm{E}+01$ & $1.0 \mathrm{E}+00$ & $2.9 \mathrm{E}+00$ & 4.2E-02 & $7.1 \mathrm{E}+00$ & $1.1 \mathrm{E}+00$ & ND \\
\hline & 42 & $\begin{array}{c}1.1 \mathrm{E}+01 \\
{[0.28]}\end{array}$ & $2.5 \mathrm{E}+01$ & $1.1 \mathrm{E}+00$ & $2.8 \mathrm{E}+00$ & $4.2 \mathrm{E}-02$ & $6.6 \mathrm{E}+00$ & $1.0 \mathrm{E}+00$ & ND \\
\hline & 49 & $\begin{array}{c}4.8 \mathrm{E}+00 \\
{[0.13]}\end{array}$ & $1.6 \mathrm{E}+01$ & ND & $2.1 \mathrm{E}+00$ & 4.9E-02 & $4.3 \mathrm{E}+00$ & ND & ND \\
\hline & 49 & $\begin{array}{c}4.7 \mathrm{E}+00 \\
{[0.12]}\end{array}$ & $1.6 \mathrm{E}+01$ & ND & $2.0 \mathrm{E}+00$ & 4.9E-02 & $4.2 \mathrm{E}+00$ & ND & ND \\
\hline & 63 & $\begin{array}{c}8.5 \mathrm{E}+00 \\
{[0.23]}\end{array}$ & $2.4 \mathrm{E}+01$ & ND & $2.6 \mathrm{E}+00$ & $6.3 \mathrm{E}-02$ & $6.0 \mathrm{E}+00$ & $1.4 \mathrm{E}+00$ & ND \\
\hline & 63 & $\begin{array}{c}8.00 \mathrm{E}+00 \\
{[0.21]}\end{array}$ & $2.3 \mathrm{E}+01$ & ND & $2.7 \mathrm{E}+00$ & $6.3 \mathrm{E}-02$ & $6.3 \mathrm{E}+00$ & $1.2 \mathrm{E}+00$ & ND \\
\hline
\end{tabular}


Table 5.13. (contd)

\begin{tabular}{|c|c|c|c|c|c|c|c|c|c|}
\hline Waste Form & $\begin{array}{l}\text { Cumul. } \\
\text { Leach } \\
\text { Time } \\
\text { (Days) }\end{array}$ & $\begin{array}{c}\mathrm{Na} \\
(\mathrm{mg} / \mathrm{L})\end{array}$ & $\begin{array}{c}\mathrm{Ca} \\
(\mathrm{mg} / \mathrm{L})\end{array}$ & $\begin{array}{c}\mathrm{K} \\
(\mathrm{mg} / \mathrm{L})\end{array}$ & $\begin{array}{c}\mathrm{Al} \\
(\mathrm{mg} / \mathrm{L})\end{array}$ & $\begin{array}{c}\mathrm{Mg} \\
(\mathrm{mg} / \mathrm{L})\end{array}$ & $\begin{array}{c}\mathrm{Si} \\
(\mathrm{mg} / \mathrm{L})\end{array}$ & $\begin{array}{c}\mathrm{S} \\
(\mathrm{mg} / \mathrm{L})\end{array}$ & $\begin{array}{c}\mathrm{Fe} \\
(\mathrm{mg} / \mathrm{L})\end{array}$ \\
\hline \multirow{18}{*}{$\begin{array}{c}\text { Geopolymer } \\
\text { Batch \#1 }\end{array}$} & 0.08 & $\begin{array}{c}1.5 \mathrm{E}+01 \\
{[0.39]}\end{array}$ & ND & $4.7 \mathrm{E}+01$ & $1.2 \mathrm{E}-01$ & ND & $7.1 \mathrm{E}-01$ & $2.1 \mathrm{E}+00$ & ND \\
\hline & 0.08 & $\begin{array}{c}1.8 \mathrm{E}+01 \\
{[0.46]}\end{array}$ & ND & $5.4 \mathrm{E}+01$ & 1.1E-01 & ND & 9.1E-01 & $3.2 \mathrm{E}+00$ & ND \\
\hline & 1 & $\begin{array}{c}4.4 \mathrm{E}+01 \\
{[1.14]}\end{array}$ & ND & $1.1 \mathrm{E}+02$ & $1.1 \mathrm{E}+00$ & ND & $3.9 \mathrm{E}+00$ & $5.9 \mathrm{E}+00$ & ND \\
\hline & 1 & $\begin{array}{c}5.1 \mathrm{E}+01 \\
{[1.33]}\end{array}$ & ND & $1.3 \mathrm{E}+02$ & $1.2 \mathrm{E}+00$ & ND & $5.0 \mathrm{E}+00$ & $1.8 \mathrm{E}+01$ & ND \\
\hline & 2 & $\begin{array}{c}3.4 \mathrm{E}+01 \\
{[0.87]}\end{array}$ & ND & $8.8 \mathrm{E}+01$ & $1.3 \mathrm{E}+00$ & ND & $3.7 \mathrm{E}+00$ & $7.8 \mathrm{E}+00$ & ND \\
\hline & 2 & $\begin{array}{c}3.9 \mathrm{E}+01 \\
{[1.00]}\end{array}$ & ND & $9.7 \mathrm{E}+01$ & $1.4 \mathrm{E}+00$ & ND & $4.7 \mathrm{E}+00$ & $1.7 \mathrm{E}+01$ & ND \\
\hline & 7 & $\begin{array}{c}9.4 \mathrm{E}+01 \\
{[2.42]}\end{array}$ & ND & $2.3 \mathrm{E}+02$ & $6.1 \mathrm{E}+00$ & $6.1 \mathrm{E}-02$ & $1.6 \mathrm{E}+01$ & $4.4 \mathrm{E}+01$ & ND \\
\hline & 7 & $\begin{array}{c}1.1 \mathrm{E}+02 \\
{[2.88]}\end{array}$ & ND & $2.7 \mathrm{E}+02$ & $6.9 \mathrm{E}+00$ & 7.3E-02 & $1.9 \mathrm{E}+01$ & $6.9 \mathrm{E}+01$ & ND \\
\hline & 14 & $\begin{array}{c}1.0 \mathrm{E}+02 \\
{[2.61]}\end{array}$ & 2.7E-01 & $2.4 \mathrm{E}+02$ & $9.1 \mathrm{E}+00$ & $2.6 \mathrm{E}-01$ & $2.1 \mathrm{E}+01$ & $4.0 \mathrm{E}+01$ & ND \\
\hline & 14 & $\begin{array}{c}1.0 \mathrm{E}+02 \\
{[2.66]}\end{array}$ & $3.2 \mathrm{E}-01$ & $2.4 \mathrm{E}+02$ & $9.1 \mathrm{E}+00$ & $2.7 \mathrm{E}-01$ & $2.2 \mathrm{E}+01$ & $5.6 \mathrm{E}+01$ & ND \\
\hline & 28 & $\begin{array}{c}1.2 \mathrm{E}+02 \\
{[2.94]}\end{array}$ & $4.3 \mathrm{E}-01$ & $2.7 \mathrm{E}+02$ & $1.1 \mathrm{E}+01$ & $3.6 \mathrm{E}-01$ & $2.7 \mathrm{E}+01$ & $7.8 \mathrm{E}+01$ & $6.7 \mathrm{E}-02$ \\
\hline & 28 & $\begin{array}{c}1.1 \mathrm{E}+02 \\
{[2.88]}\end{array}$ & $2.3 \mathrm{E}-01$ & $2.2 \mathrm{E}+02$ & $8.6 \mathrm{E}+00$ & $2.4 \mathrm{E}-01$ & $2.3 \mathrm{E}+01$ & $1.1 \mathrm{E}+02$ & $5.4 \mathrm{E}-02$ \\
\hline & 42 & $\begin{array}{c}7.3 \mathrm{E}+01 \\
{[1.97]}\end{array}$ & $2.1 \mathrm{E}-01$ & $1.4 \mathrm{E}+02$ & $8.7 \mathrm{E}+00$ & $2.4 \mathrm{E}-01$ & $2.1 \mathrm{E}+01$ & $5.9 \mathrm{E}+01$ & $5.6 \mathrm{E}-02$ \\
\hline & 42 & $\begin{array}{c}7.2 \mathrm{E}+01 \\
{[1.91]}\end{array}$ & $2.0 \mathrm{E}-01$ & $1.4 \mathrm{E}+02$ & $8.7 \mathrm{E}+00$ & $2.5 \mathrm{E}-01$ & $2.1 \mathrm{E}+01$ & $6.1 \mathrm{E}+01$ & $5.5 \mathrm{E}-02$ \\
\hline & 49 & $\begin{array}{c}3.2 \mathrm{E}+01 \\
{[0.83]}\end{array}$ & $9.8 \mathrm{E}-02$ & $6.2 \mathrm{E}+01$ & $6.1 \mathrm{E}+00$ & $1.5 \mathrm{E}-01$ & $1.4 \mathrm{E}+01$ & $2.0 \mathrm{E}+01$ & 4.6E-02 \\
\hline & 49 & $\begin{array}{c}3.3 \mathrm{E}+01 \\
{[0.85]}\end{array}$ & $9.4 \mathrm{E}-02$ & $6.3 \mathrm{E}+01$ & $6.2 \mathrm{E}+00$ & $1.5 \mathrm{E}-01$ & $1.4 \mathrm{E}+01$ & $2.0 \mathrm{E}+01$ & 4.9E-02 \\
\hline & 63 & $\begin{array}{c}4.4 \mathrm{E}+01 \\
{[1.21]}\end{array}$ & $1.5 \mathrm{E}-01$ & $8.1 \mathrm{E}+01$ & $7.6 \mathrm{E}+00$ & $2.0 \mathrm{E}-01$ & $1.9 \mathrm{E}+01$ & $2.9 \mathrm{E}+01$ & $6.6 \mathrm{E}-02$ \\
\hline & 63 & $\begin{array}{c}4.6 \mathrm{E}+01 \\
{[1.22]}\end{array}$ & $1.2 \mathrm{E}-01$ & $8.6 \mathrm{E}+01$ & $7.9 \mathrm{E}+00$ & $2.1 \mathrm{E}-01$ & $1.9 \mathrm{E}+01$ & $2.9 \mathrm{E}+01$ & 7.0E-02 \\
\hline
\end{tabular}


Table 5.13. (contd)

\begin{tabular}{|c|c|c|c|c|c|c|c|c|c|}
\hline Waste Form & $\begin{array}{l}\text { Cumul. } \\
\text { Leach } \\
\text { Time } \\
\text { (Days) }\end{array}$ & $\begin{array}{c}\mathrm{Na} \\
(\mathrm{mg} / \mathrm{L})\end{array}$ & $\begin{array}{c}\mathrm{Ca} \\
(\mathrm{mg} / \mathrm{L})\end{array}$ & $\begin{array}{c}\mathrm{K} \\
(\mathrm{mg} / \mathrm{L})\end{array}$ & $\begin{array}{c}\mathrm{Al} \\
(\mathrm{mg} / \mathrm{L})\end{array}$ & $\begin{array}{c}\mathrm{Mg} \\
(\mathrm{mg} / \mathrm{L})\end{array}$ & $\begin{array}{c}\mathrm{Si} \\
(\mathrm{mg} / \mathrm{L})\end{array}$ & $\underset{(\mathrm{mg} / \mathrm{L})}{\mathrm{S}}$ & $\begin{array}{c}\mathrm{Fe} \\
(\mathrm{mg} / \mathrm{L})\end{array}$ \\
\hline \multirow{18}{*}{$\begin{array}{c}\text { Geopolymer } \\
\text { Batch \#2 }\end{array}$} & 0.08 & $\begin{array}{c}2.3 \mathrm{E}+01 \\
{[0.66]}\end{array}$ & ND & $5.5 \mathrm{E}+01$ & $1.7 \mathrm{E}-01$ & ND & ND & $7.8 \mathrm{E}+00$ & ND \\
\hline & 0.08 & $\begin{array}{c}2.4 \mathrm{E}+02 \\
{[0.69]}\end{array}$ & ND & $5.7 \mathrm{E}+01$ & $1.5 \mathrm{E}-01$ & ND & ND & $8.5 \mathrm{E}+00$ & ND \\
\hline & 1 & $\begin{array}{c}5.4 \mathrm{E}+01 \\
{[1.53]}\end{array}$ & ND & $1.2 \mathrm{E}+02$ & $9.5 \mathrm{E}-01$ & ND & $2.8 \mathrm{E}+00$ & $1.9 \mathrm{E}+01$ & ND \\
\hline & 1 & $\begin{array}{c}5.6 \mathrm{E}+01 \\
{[1.60]}\end{array}$ & ND & $1.2 \mathrm{E}+02$ & $9.4 \mathrm{E}-01$ & ND & $2.9 \mathrm{E}+00$ & $2.6 \mathrm{E}+01$ & ND \\
\hline & 2 & $\begin{array}{c}4.0 \mathrm{E}+01 \\
{[1.15]}\end{array}$ & ND & $8.9 \mathrm{E}+01$ & $1.1 \mathrm{E}+00$ & ND & $3.1 \mathrm{E}+00$ & $2.0 \mathrm{E}+01$ & ND \\
\hline & 2 & $\begin{array}{c}4.1 \mathrm{E}+01 \\
{[1.17]}\end{array}$ & ND & $9.0 \mathrm{E}+01$ & $1.2 \mathrm{E}+00$ & ND & $3.2 \mathrm{E}+00$ & $2.5 \mathrm{E}+01$ & ND \\
\hline & 7 & $\begin{array}{c}1.2 \mathrm{E}+02 \\
{[3.38]}\end{array}$ & ND & $2.5 \mathrm{E}+02$ & $5.1 \mathrm{E}+00$ & $3.5 \mathrm{E}-02$ & $1.4 \mathrm{E}+01$ & $1.0 \mathrm{E}+02$ & ND \\
\hline & 7 & $\begin{array}{c}1.2 \mathrm{E}+02 \\
{[3.33]}\end{array}$ & ND & $2.4 \mathrm{E}+02$ & $5.1 \mathrm{E}+00$ & $3.4 \mathrm{E}-02$ & $1.4 \mathrm{E}+01$ & $9.2 \mathrm{E}+01$ & ND \\
\hline & 14 & $\begin{array}{c}9.5 \mathrm{E}+01 \\
{[2.70]}\end{array}$ & ND & $2.0 \mathrm{E}+02$ & $6.5 \mathrm{E}+00$ & $1.5 \mathrm{E}-01$ & $1.7 \mathrm{E}+01$ & $6.9 \mathrm{E}+01$ & ND \\
\hline & 14 & $\begin{array}{c}1.0 \mathrm{E}+02 \\
{[2.91]}\end{array}$ & ND & $2.1 \mathrm{E}+02$ & $6.8 \mathrm{E}+00$ & $1.4 \mathrm{E}-01$ & $1.7 \mathrm{E}+01$ & $6.4 \mathrm{E}+01$ & ND \\
\hline & 28 & $\begin{array}{c}2.8 \mathrm{E}-02 \\
{[3.39]}\end{array}$ & $4.3 \mathrm{E}-01$ & $2.7 \mathrm{E}+02$ & $1.1 \mathrm{E}+01$ & $3.6 \mathrm{E}-01$ & $2.7 \mathrm{E}-01$ & $7.8 \mathrm{E}+01$ & $6.7 \mathrm{E}-02$ \\
\hline & 28 & $\begin{array}{c}2.8 \mathrm{E}-02 \\
{[3.15]}\end{array}$ & $2.3 \mathrm{E}-01$ & $2.2 \mathrm{E}+02$ & $8.4 \mathrm{E}+00$ & 2.3E-01 & $2.2 \mathrm{E}-01$ & $1.1 \mathrm{E}+02$ & $5.4 \mathrm{E}-02$ \\
\hline & 42 & $\begin{array}{c}4.2 \mathrm{E}-02 \\
{[2.07]}\end{array}$ & $2.1 \mathrm{E}-01$ & $1.4 \mathrm{E}+02$ & $1.0 \mathrm{E}+01$ & $3.9 \mathrm{E}-01$ & $1.4 \mathrm{E}-01$ & $5.9 \mathrm{E}+01$ & $5.6 \mathrm{E}-02$ \\
\hline & 42 & $\begin{array}{c}4.2 \mathrm{E}-02 \\
{[2.05]}\end{array}$ & $2.0 \mathrm{E}-01$ & $1.4 \mathrm{E}+02$ & $1.0 \mathrm{E}+01$ & 3.9E-01 & $1.4 \mathrm{E}-01$ & $6.1 \mathrm{E}+01$ & $5.5 \mathrm{E}-02$ \\
\hline & 49 & $\begin{array}{c}4.9 \mathrm{E}-02 \\
{[0.91]}\end{array}$ & ND & $6.2 \mathrm{E}+01$ & $7.2 \mathrm{E}+00$ & $2.8 \mathrm{E}-01$ & $6.2 \mathrm{E}-02$ & $2.0 \mathrm{E}+01$ & 4.6E-02 \\
\hline & 49 & $\begin{array}{c}4.9 \mathrm{E}-02 \\
{[0.94]}\end{array}$ & ND & $6.3 \mathrm{E}+01$ & $7.2 \mathrm{E}+00$ & $3.0 \mathrm{E}-01$ & $6.3 \mathrm{E}-02$ & $2.0 \mathrm{E}+01$ & 4.9E-02 \\
\hline & 63 & $\begin{array}{c}6.3 \mathrm{E}-02 \\
{[1.24]}\end{array}$ & ND & $8.1 \mathrm{E}+01$ & $9.6 \mathrm{E}+00$ & $3.4 \mathrm{E}-01$ & $8.1 \mathrm{E}-02$ & $2.9 \mathrm{E}+01$ & $6.6 \mathrm{E}-02$ \\
\hline & 63 & $\begin{array}{c}6.3 \mathrm{E}-02 \\
{[1.31]}\end{array}$ & ND & $8.6 \mathrm{E}+01$ & $9.8 \mathrm{E}+00$ & $3.6 \mathrm{E}-01$ & $8.6 \mathrm{E}-02$ & $2.9 \mathrm{E}+01$ & $7.0 \mathrm{E}-02$ \\
\hline $\begin{array}{l}\text { (a) ND-sam } \\
\text { (b) Percentag } \\
\text { spiked iodine, } 1\end{array}$ & $\begin{array}{l}\text { "not dete } \\
\text { leaching }\end{array}$ & $\begin{array}{l}\text { "; value be } \\
\text { is also sho }\end{array}$ & $\begin{array}{l}\text { minimu } \\
\text { in bracke }\end{array}$ & ], below $\mathrm{m}$ & red conce & $\begin{array}{l}\text { tions (mg } \\
\text { DL. }\end{array}$ & Because & ow concen & on of \\
\hline
\end{tabular}


Table 5.14. The Concentrations of RCRA Metals in Eluate for Waste Forms from EPA Method $1315^{(\mathrm{a}),(\mathrm{b})}$

\begin{tabular}{|c|c|c|c|c|c|c|}
\hline Waste Form & $\begin{array}{l}\text { Cumul. Leach } \\
\text { Time } \\
\text { (Days) }\end{array}$ & $\begin{array}{c}\mathrm{Cd} \\
(\mu \mathrm{g} / \mathrm{L})\end{array}$ & $\begin{array}{c}\mathrm{Cr} \\
(\mu \mathrm{g} / \mathrm{L})\end{array}$ & $\begin{array}{c}\mathrm{Pb} \\
(\mu \mathrm{g} / \mathrm{L})\end{array}$ & $\underset{(\mu \mathrm{g} / \mathrm{L})}{\mathrm{Ag}}$ & $\underset{(\mu \mathrm{g} / \mathrm{L})}{\mathrm{Hg}}$ \\
\hline \multirow{18}{*}{ Cast Stone } & 0.08 & ND & ND & ND & ND & ND \\
\hline & 0.08 & ND & ND & ND & ND & ND \\
\hline & 1 & ND & ND & ND & ND & ND \\
\hline & 1 & ND & ND & ND & ND & ND \\
\hline & 2 & ND & ND & ND & ND & ND \\
\hline & 2 & ND & ND & ND & ND & ND \\
\hline & 7 & ND & $2.2 \mathrm{E}-01$ & ND & ND & ND \\
\hline & 7 & ND & ND & ND & ND & ND \\
\hline & 14 & ND & ND & ND & ND & ND \\
\hline & 14 & ND & ND & ND & ND & ND \\
\hline & 28 & ND & ND & ND & ND & ND \\
\hline & 28 & ND & ND & ND & ND & ND \\
\hline & 42 & ND & ND & ND & ND & ND \\
\hline & 42 & ND & ND & $9.2 \mathrm{E}-01$ & ND & ND \\
\hline & 49 & ND & ND & ND & ND & ND \\
\hline & 49 & ND & ND & ND & ND & ND \\
\hline & 63 & ND & ND & ND & ND & ND \\
\hline & 63 & ND & ND & ND & ND & ND \\
\hline \multirow{18}{*}{$\begin{array}{l}\text { Geopolymer } \\
\text { Batch \#1 }\end{array}$} & 0.08 & ND & ND & ND & ND & ND \\
\hline & 0.08 & ND & ND & ND & ND & ND \\
\hline & 1 & ND & ND & ND & ND & ND \\
\hline & 1 & ND & ND & ND & ND & ND \\
\hline & 2 & ND & ND & ND & ND & $5.7 \mathrm{E}-01$ \\
\hline & 2 & $\mathrm{ND}$ & ND & ND & ND & $6.2 \mathrm{E}-01$ \\
\hline & 7 & $\mathrm{ND}$ & $1.6 \mathrm{E}+00$ & ND & ND & ND \\
\hline & 7 & ND & $1.5 \mathrm{E}+00$ & ND & ND & ND \\
\hline & 14 & ND & $2.3 \mathrm{E}+00$ & $2.8 \mathrm{E}+00$ & ND & ND \\
\hline & 14 & ND & $2.2 \mathrm{E}+00$ & $2.8 \mathrm{E}+00$ & ND & $8.0 \mathrm{E}-01$ \\
\hline & 28 & $\mathrm{ND}$ & $2.7 \mathrm{E}+00$ & $4.0 \mathrm{E}+00$ & ND & ND \\
\hline & 28 & $\mathrm{ND}$ & $2.8 \mathrm{E}+00$ & $4.1 \mathrm{E}+00$ & ND & $1.1 \mathrm{E}+00$ \\
\hline & 42 & ND & $3.2 \mathrm{E}+00$ & $3.2 \mathrm{E}+00$ & ND & ND \\
\hline & 42 & ND & $2.7 \mathrm{E}+00$ & $3.4 \mathrm{E}+00$ & ND & ND \\
\hline & 49 & $\mathrm{ND}$ & $2.0 \mathrm{E}+00$ & $1.7 \mathrm{E}+00$ & ND & ND \\
\hline & 49 & ND & $2.1 \mathrm{E}+00$ & $1.7 \mathrm{E}+00$ & ND & 5.1E-01 \\
\hline & 63 & ND & $2.6 \mathrm{E}+00$ & $1.9 \mathrm{E}+00$ & ND & ND \\
\hline & 63 & ND & $2.6 \mathrm{E}+00$ & $3.0 \mathrm{E}+00$ & ND & $6.0 \mathrm{E}-01$ \\
\hline
\end{tabular}


Table 5.14. (contd)

\begin{tabular}{|c|c|c|c|c|c|c|}
\hline Waste Form & $\begin{array}{l}\text { Cumul. Leach } \\
\text { Time (Days) }\end{array}$ & $\mathrm{Cd}(\mu \mathrm{g} / \mathrm{L})$ & $\operatorname{Cr}(\mu \mathrm{g} / \mathrm{L})$ & $\mathrm{Pb}(\mu \mathrm{g} / \mathrm{L})$ & $\operatorname{Ag}(\mu \mathrm{g} / \mathrm{L})$ & $\mathrm{Hg}(\mu \mathrm{g} / \mathrm{L})$ \\
\hline \multirow{18}{*}{$\begin{array}{c}\text { Geopolymer } \\
\text { Batch \#2 }\end{array}$} & 0.08 & $\mathrm{ND}$ & $3.8 \mathrm{E}+00$ & ND & ND & $\mathrm{ND}$ \\
\hline & 0.08 & ND & $4.3 \mathrm{E}+00$ & ND & ND & ND \\
\hline & 1 & ND & $8.7 \mathrm{E}+00$ & ND & ND & ND \\
\hline & 1 & ND & $1.0 \mathrm{E}+01$ & ND & ND & ND \\
\hline & 2 & ND & $6.4 \mathrm{E}+00$ & ND & ND & ND \\
\hline & 2 & ND & $7.7 \mathrm{E}+00$ & ND & ND & ND \\
\hline & 7 & ND & $2.4 \mathrm{E}+00$ & ND & ND & $3.5 \mathrm{E}-01$ \\
\hline & 7 & ND & $3.1 \mathrm{E}+00$ & ND & ND & 3.6E-01 \\
\hline & 14 & ND & $2.7 \mathrm{E}+00$ & $1.4 \mathrm{E}+00$ & ND & ND \\
\hline & 14 & ND & $2.5 \mathrm{E}+00$ & $1.2 \mathrm{E}+00$ & ND & ND \\
\hline & 28 & ND & $3.4 \mathrm{E}+00$ & $2.6 \mathrm{E}+00$ & ND & ND \\
\hline & 28 & ND & $3.6 \mathrm{E}+00$ & $2.3 \mathrm{E}+00$ & ND & ND \\
\hline & 42 & ND & $3.0 \mathrm{E}+00$ & $1.8 \mathrm{E}+00$ & ND & ND \\
\hline & 42 & ND & $3.3 \mathrm{E}+00$ & $2.0 \mathrm{E}+00$ & ND & ND \\
\hline & 49 & ND & $1.8 \mathrm{E}+00$ & $1.0 \mathrm{E}+00$ & $1.1 \mathrm{E}+01$ & ND \\
\hline & 49 & ND & $1.7 \mathrm{E}+00$ & $1.3 \mathrm{E}+00$ & $1.1 \mathrm{E}+01$ & ND \\
\hline & 63 & ND & $2.6 \mathrm{E}+00$ & $2.2 \mathrm{E}+00$ & $1.1 \mathrm{E}+01$ & ND \\
\hline & 63 & ND & $2.8 \mathrm{E}+00$ & $1.9 \mathrm{E}+00$ & $1.1 \mathrm{E}+01$ & ND \\
\hline $\begin{array}{ll}\text { (a) } & N D-s a m p \\
\text { (b) } & \mathrm{NM} \text { - } \mathrm{sam}\end{array}$ & $\begin{array}{l}\text { letected"; value } \\
\text { leasured }\end{array}$ & inimum c & & & & \\
\hline
\end{tabular}


Table 5.15.The Concentrations of Major Anions, ${ }^{99} \mathrm{Tc}$, and ${ }^{127} \mathrm{I}$ in Eluate for Waste Forms from EPA Method 1315

\begin{tabular}{|c|c|c|c|c|c|c|c|c|}
\hline Waste Form & $\begin{array}{c}\text { Cumulative } \\
\text { Leaching Time } \\
\text { (Days) }\end{array}$ & $\begin{array}{c}\mathrm{NO}_{3}{ }^{-} \\
(\mathrm{mg} / \mathrm{L})\end{array}$ & $\begin{array}{c}\mathrm{PO}_{4}{ }^{3-} \\
(\mathrm{mg} / \mathrm{L})\end{array}$ & $\begin{array}{c}\mathrm{PO}_{4}{ }^{3-} \\
(\mathrm{mg} / \mathrm{L})^{(\mathrm{a})}\end{array}$ & $\begin{array}{c}\mathrm{SO}_{4}^{2-} \\
(\mathrm{mg} / \mathrm{L}) \\
\end{array}$ & $\begin{array}{c}\mathrm{SO}_{4}{ }^{2-} \\
(\mathrm{mg} / \mathrm{L})^{(a)}\end{array}$ & $\begin{array}{c}{ }^{127} \mathrm{I}^{-} \\
(\mu \mathrm{g} / \mathrm{L})\end{array}$ & $\begin{array}{c}{ }^{99} \mathrm{Tc} \\
(\mu \mathrm{g} / \mathrm{L})\end{array}$ \\
\hline \multirow{20}{*}{ Cast Stone } & 0.08 & $2.2 \mathrm{E}+00$ & ND & ND & $3.7 \mathrm{E}+00$ & ND & $\begin{array}{c}1.2 \mathrm{E}+02 \\
{[<1.1 \mathrm{E}+02]}\end{array}$ & $\begin{array}{c}1.0 \mathrm{E}-02 \\
{[0.03]}\end{array}$ \\
\hline & 0.08 & $2.1 \mathrm{E}+00$ & ND & ND & $3.5 \mathrm{E}+00$ & ND & $\begin{array}{c}1.4 \mathrm{E}+02 \\
{[<1.3 \mathrm{E}+02]}\end{array}$ & $\begin{array}{c}8.7 \mathrm{E}-03 \\
{[0.03]}\end{array}$ \\
\hline & 1 & $1.0 \mathrm{E}+00$ & ND & ND & $2.0 \mathrm{E}+00$ & ND & $\begin{array}{c}\mathrm{ND} \\
{[<1.3 \mathrm{E}+01]}\end{array}$ & $\begin{array}{c}8.8 \mathrm{E}-03 \\
{[0.03]}\end{array}$ \\
\hline & 1 & $1.1 \mathrm{E}+00$ & ND & ND & $2.2 \mathrm{E}+00$ & ND & $\begin{array}{c}\mathrm{ND} \\
{[<1.3 \mathrm{E}+01]}\end{array}$ & $\begin{array}{c}8.1 \mathrm{E}-03 \\
{[0.03]}\end{array}$ \\
\hline & 2 & ND & ND & ND & $1.9 \mathrm{E}+00$ & ND & $\begin{array}{c}5.2 \mathrm{E}+01 \\
{[<4.9 \mathrm{E}+01]}\end{array}$ & $\begin{array}{l}\text { ND } \\
{[0.01]}\end{array}$ \\
\hline & 2 & NID & ND & NID & ח & ND & $1.0 \mathrm{E}+02$ & ND \\
\hline & 2 & ND & ND & ND & $2.0 \mathrm{E}+00$ & ND & $\begin{array}{c}{[<9.6 \mathrm{E}+01]} \\
\mathrm{ND}\end{array}$ & $\begin{array}{l}{[0.01]} \\
84 \mathrm{~F}-03\end{array}$ \\
\hline & 7 & ND & ND & ND & $2.7 \mathrm{E}+00$ & $6.8 \mathrm{E}+00$ & {$[<1.3 \mathrm{E}+01]$} & {$[0.03]$} \\
\hline & 7 & ND & ND & ND & $2.7 \mathrm{E}+00$ & $6.1 \mathrm{E}+00$ & $\begin{array}{c}\mathrm{ND} \\
{[<1.3 \mathrm{E}+01]}\end{array}$ & $\begin{array}{c}7.8 \mathrm{E}-03 \\
{[0.03]}\end{array}$ \\
\hline & & & & & & & $3.2 \mathrm{E}+01$ & $5.8 \mathrm{E}-03$ \\
\hline & 14 & ND & ND & ND & $2.3 \mathrm{E}+00$ & $3.2 \mathrm{E}+00$ & {$[<3.0 \mathrm{E}+01]$} & {$[0.02]$} \\
\hline & 14 & ND & ND & ND & $2.4 \mathrm{E}+00$ & $2.3 \mathrm{E}+00$ & $\begin{array}{c}4.3 \mathrm{E}+01 \\
{[<4.0 \mathrm{E}+01]}\end{array}$ & $\begin{array}{c}6.8 \mathrm{E}-03 \\
{[0.02]}\end{array}$ \\
\hline & 28 & ND & ND & ND & $3.1 \mathrm{E}+00$ & ND & $\begin{array}{l}\text { ND } \\
{[<6.4]}\end{array}$ & $\begin{array}{c}8.4 \mathrm{E}-03 \\
{[0.03]}\end{array}$ \\
\hline & 28 & ND & ND & ND & $3.1 \mathrm{E}+00$ & ND & $\begin{array}{l}5.6 \mathrm{E}-01 \\
{[<0.52]}\end{array}$ & $\begin{array}{c}8.0 \mathrm{E}-03 \\
{[0.03]}\end{array}$ \\
\hline & 42 & ND & ND & ND & $2.7 \mathrm{E}+00$ & ND & $\begin{array}{c}\mathrm{ND} \\
{[<1.3 \mathrm{E}+01]}\end{array}$ & $\begin{array}{c}6.6 \mathrm{E}-03 \\
{[0.02]}\end{array}$ \\
\hline & 42 & ND & ND & ND & $2.8 \mathrm{E}+00$ & ND & $\begin{array}{c}\mathrm{ND} \\
{[<1.3 \mathrm{E}+01]}\end{array}$ & $\begin{array}{c}7.4 \mathrm{E}-03 \\
{[0.02]}\end{array}$ \\
\hline & 49 & ND & ND & ND & $2.7 \mathrm{E}+00$ & ND & $\begin{array}{c}\mathrm{ND} \\
{[<1.3 \mathrm{E}+01]}\end{array}$ & $\begin{array}{l}\text { ND } \\
{[0.01]}\end{array}$ \\
\hline & 49 & ND & ND & ND & $2.6 \mathrm{E}+00$ & ND & $\begin{array}{c}\mathrm{ND} \\
{[<1.3 \mathrm{E}+01]}\end{array}$ & $\begin{array}{l}\text { ND } \\
{[0.01]}\end{array}$ \\
\hline & 63 & ND & ND & ND & $4.1 \mathrm{E}+00$ & ND & $\begin{array}{c}\mathrm{ND} \\
{[<1.3 \mathrm{E}+01]}\end{array}$ & $\begin{array}{c}7.9 \mathrm{E}-03 \\
{[0.03]}\end{array}$ \\
\hline & 63 & ND & ND & ND & $3.3 \mathrm{E}+00$ & ND & $\begin{array}{c}\mathrm{ND} \\
{[<1.3 \mathrm{E}+01]}\end{array}$ & $\begin{array}{c}7.8 \mathrm{E}-03 \\
{[0.03]}\end{array}$ \\
\hline
\end{tabular}




\begin{tabular}{|c|c|c|c|c|c|c|c|c|}
\hline \multicolumn{9}{|c|}{ Table 5.15. (contd) } \\
\hline Waste Form & $\begin{array}{c}\text { Cumulative } \\
\text { Leaching Time } \\
\text { (Days) }\end{array}$ & $\begin{array}{c}\mathrm{NO}_{3}^{-} \\
(\mathrm{mg} / \mathrm{L})\end{array}$ & $\begin{array}{l}\mathrm{PO}_{4}{ }^{3-} \\
(\mathrm{mg} / \mathrm{L})\end{array}$ & $\begin{array}{c}\mathrm{PO}_{4}{ }^{3-} \\
(\mathrm{mg} / \mathrm{L})^{(\mathrm{a})}\end{array}$ & $\begin{array}{l}\mathrm{SO}_{4}^{2-} \\
(\mathrm{mg} / \mathrm{L})\end{array}$ & $\begin{array}{c}\mathrm{SO}_{4}{ }^{2-} \\
(\mathrm{mg} / \mathrm{L})^{(\mathrm{a})}\end{array}$ & $\begin{array}{c}{ }^{127} \mathrm{I}^{-} \\
(\mu \mathrm{g} / \mathrm{L})\end{array}$ & $\begin{array}{c}{ }^{99} \mathrm{Tc} \\
(\mu \mathrm{g} / \mathrm{L})\end{array}$ \\
\hline \multirow{19}{*}{$\begin{array}{c}\text { Geopolymer } \\
\text { Batch \#1 }\end{array}$} & 0.08 & $3.8 \mathrm{E}+01$ & ND & ND & ND & $6.4 \mathrm{E}+00$ & $\begin{array}{c}\mathrm{ND} \\
{[<6.9]}\end{array}$ & $\begin{array}{c}3.4 \mathrm{E}-02 \\
{[0.06]}\end{array}$ \\
\hline & 0.08 & $4.3 \mathrm{E}+01$ & ND & ND & ND & $9.7 \mathrm{E}+00$ & $\begin{array}{c}6.6 \mathrm{E}+01 \\
{[6.7 \mathrm{E}+01]}\end{array}$ & $\begin{array}{c}8.0 \mathrm{E}-02 \\
{[0.13]}\end{array}$ \\
\hline & 1 & $9.0 \mathrm{E}+01$ & ND & ND & ND & $1.8 \mathrm{E}+01$ & $\begin{array}{c}1.7 \mathrm{E}+02 \\
{[1.7 \mathrm{E}+02]}\end{array}$ & $\begin{array}{c}6.4 \mathrm{E}-02 \\
{[0.11]}\end{array}$ \\
\hline & 1 & $1.1 \mathrm{E}+02$ & ND & ND & $1.5 \mathrm{E}+01$ & $5.5 \mathrm{E}+01$ & $\begin{array}{c}1.7 \mathrm{E}+02 \\
{[1.8 \mathrm{E}+02]}\end{array}$ & $\begin{array}{c}9.0 \mathrm{E}-02 \\
{[0.15]}\end{array}$ \\
\hline & 2 & $6.4 \mathrm{E}+01$ & ND & ND & ND & $2.3 \mathrm{E}+01$ & $\begin{array}{c}4.0 \mathrm{E}+01 \\
{[4.0 \mathrm{E}+01]}\end{array}$ & $\begin{array}{c}5.4 \mathrm{E}-02 \\
{[0.09]}\end{array}$ \\
\hline & 2 & $7.8 \mathrm{E}+01$ & ND & ND & ND & $5.2 \mathrm{E}+01$ & $\begin{array}{c}5.0 \mathrm{E}+01 \\
{[5.0 \mathrm{E}+01]}\end{array}$ & $\begin{array}{c}6.1 \mathrm{E}-02 \\
{[0.10]}\end{array}$ \\
\hline & 7 & $1.9 \mathrm{E}+02$ & ND & ND & $2.0 \mathrm{E}+01$ & $1.3 \mathrm{E}+02$ & $\begin{array}{c}1.1 \mathrm{E}+02 \\
{[1.1 \mathrm{E}+02]}\end{array}$ & $\begin{array}{c}1.6 \mathrm{E}-01 \\
{[0.26]}\end{array}$ \\
\hline & 7 & $2.3 \mathrm{E}+02$ & ND & ND & ND & $2.1 \mathrm{E}+02$ & $\begin{array}{c}1.2 \mathrm{E}+02 \\
{[1.2 \mathrm{E}+02]}\end{array}$ & $\begin{array}{c}2.4 \mathrm{E}-01 \\
{[0.39]}\end{array}$ \\
\hline & 14 & $2.1 \mathrm{E}+02$ & ND & ND & $2.6 \mathrm{E}+01$ & $1.2 \mathrm{E}+02$ & $\begin{array}{c}\text { ND } \\
{[<6.89]}\end{array}$ & $\begin{array}{c}1.0 \mathrm{E}-01 \\
{[0.17]}\end{array}$ \\
\hline & & & & & & & $1.0 \mathrm{E}+01$ & $1.7 \mathrm{E}-01$ \\
\hline & 14 & $2.1 \mathrm{E}+02$ & ND & ND & $2.8 \mathrm{E}+01$ & $1.7 \mathrm{E}+02$ & {$[1.0 \mathrm{E}+01]$} & {$[0.28]$} \\
\hline & 28 & $2.2 \mathrm{E}+02$ & ND & ND & ND & $3.9 \mathrm{E}-03$ & $\begin{array}{c}1.4 \mathrm{E}+01 \\
{[1.4 \mathrm{E}+01]}\end{array}$ & $\begin{array}{c}1.0 \mathrm{E}-01 \\
{[0.17]}\end{array}$ \\
\hline & 28 & $1.8 \mathrm{E}+02$ & ND & ND & ND & $3.3 \mathrm{E}-03$ & $\begin{array}{c}\mathrm{ND} \\
{[<1.4 \mathrm{E}+01]}\end{array}$ & $\begin{array}{c}1.7 \mathrm{E}-01 \\
{[0.28]}\end{array}$ \\
\hline & 42 & $1.0 \mathrm{E}+02$ & ND & ND & ND & $3.2 \mathrm{E}-03$ & $\begin{array}{c}\mathrm{ND} \\
{[<1.4 \mathrm{E}+01]}\end{array}$ & $\begin{array}{c}6.9 \mathrm{E}-02 \\
{[0.11]}\end{array}$ \\
\hline & 42 & $9.1 \mathrm{E}+01$ & ND & ND & ND & $3.1 \mathrm{E}-03$ & $\begin{array}{c}\mathrm{ND} \\
{[<1.4 \mathrm{E}+01]}\end{array}$ & $\begin{array}{c}9.6 \mathrm{E}-02 \\
{[0.16]}\end{array}$ \\
\hline & 49 & $3.0 \mathrm{E}+01$ & ND & ND & ND & $2.5 \mathrm{E}-03$ & $\begin{array}{c}\mathrm{ND} \\
{[<1.4 \mathrm{E}+01]}\end{array}$ & $\begin{array}{c}3.0 \mathrm{E}-02 \\
{[0.05]}\end{array}$ \\
\hline & 49 & $2.6 \mathrm{E}+01$ & ND & ND & ND & $2.4 \mathrm{E}-03$ & $\begin{array}{c}\mathrm{ND} \\
{[<1.4 \mathrm{E}+01]}\end{array}$ & $\begin{array}{c}3.9 \mathrm{E}-02 \\
{[0.06]}\end{array}$ \\
\hline & 63 & $3.5 \mathrm{E}+02$ & ND & ND & ND & $4.2 \mathrm{E}-03$ & $\begin{array}{c}\mathrm{ND} \\
{[<1.4 \mathrm{E}+01]}\end{array}$ & $\begin{array}{c}3.8 \mathrm{E}-02 \\
{[0.06]}\end{array}$ \\
\hline & 63 & $3.0 \mathrm{E}+02$ & ND & ND & ND & 3.7E-03 & $\begin{array}{c}\mathrm{ND} \\
{[<1.4 \mathrm{E}+01]}\end{array}$ & $\begin{array}{c}5.8 \mathrm{E}-02 \\
{[0.10]}\end{array}$ \\
\hline
\end{tabular}


Table 5.15. (contd)

\begin{tabular}{|c|c|c|c|c|c|c|c|c|}
\hline Waste Form & $\begin{array}{l}\text { Cumulative } \\
\text { Leaching Time } \\
\text { (Days) }\end{array}$ & $\begin{array}{c}\mathrm{NO}_{3}^{-} \\
(\mathrm{mg} / \mathrm{L})\end{array}$ & $\begin{array}{l}\mathrm{PO}_{4}{ }^{3-} \\
(\mathrm{mg} / \mathrm{L})\end{array}$ & $\begin{array}{c}\mathrm{PO}_{4}^{3-} \\
(\mathrm{mg} / \mathrm{L})^{(\mathrm{a})}\end{array}$ & $\begin{array}{l}\mathrm{SO}_{4}^{2-} \\
(\mathrm{mg} / \mathrm{L})\end{array}$ & $\begin{array}{c}\mathrm{SO}_{4}^{2-} \\
(\mathrm{mg} / \mathrm{L})^{(\mathrm{a})}\end{array}$ & $\begin{array}{c}{ }^{127} \mathrm{I}^{-} \\
(\mu \mathrm{g} / \mathrm{L})\end{array}$ & $\begin{array}{c}{ }^{99} \mathrm{Tc} \\
(\mu \mathrm{g} / \mathrm{L})\end{array}$ \\
\hline \multirow{19}{*}{$\begin{array}{c}\text { Geopolymer } \\
\text { Batch \#2 }\end{array}$} & 0.08 & $6.2 \mathrm{E}+01$ & ND & ND & $8.0 \mathrm{E}+00$ & $2.3 \mathrm{E}+01$ & $\begin{array}{c}2.7 \mathrm{E}+01 \\
{[2.1 \mathrm{E}+01]}\end{array}$ & $\begin{array}{c}2.4 \mathrm{E}-01 \\
{[0.53]}\end{array}$ \\
\hline & 0.08 & $6.5 \mathrm{E}+01$ & ND & ND & $8.9 \mathrm{E}+00$ & $2.6 \mathrm{E}+01$ & $\begin{array}{c}1.9 \mathrm{E}+01 \\
{[1.5 \mathrm{E}+01]}\end{array}$ & $\begin{array}{c}2.7 \mathrm{E}-01 \\
{[0.59]}\end{array}$ \\
\hline & 1 & $1.2 \mathrm{E}+02$ & ND & ND & $1.8 \mathrm{E}+01$ & $5.8 \mathrm{E}+01$ & $\begin{array}{c}5.5 \mathrm{E}+01 \\
{[4.3 \mathrm{E}+01]}\end{array}$ & $\begin{array}{c}6.6 \mathrm{E}-01 \\
{[1.48]}\end{array}$ \\
\hline & 1 & $1.3 \mathrm{E}+02$ & ND & ND & $2.0 \mathrm{E}+01$ & $7.7 \mathrm{E}+01$ & $\begin{array}{c}1.4 \mathrm{E}+02 \\
{[1.1 \mathrm{E}+02]}\end{array}$ & $\begin{array}{c}7.6 \mathrm{E}-01 \\
{[1.71]}\end{array}$ \\
\hline & 2 & $9.8 \mathrm{E}+01$ & ND & ND & $1.6 \mathrm{E}+01$ & $5.9 \mathrm{E}+01$ & $\begin{array}{c}4.7 \mathrm{E}+01 \\
{[3.68 \mathrm{E}+01]}\end{array}$ & $\begin{array}{c}5.8 \mathrm{E}-01 \\
{[1.30]}\end{array}$ \\
\hline & & & & & & & $9.8 \mathrm{E}+01$ & 6.9E-01 \\
\hline & 2 & $1.0 \mathrm{E}+02$ & ND & ND & $1.8 \mathrm{E}+01$ & $7.4 \mathrm{E}+01$ & {$[7.61 \mathrm{E}+01]$} & [1.54] \\
\hline & 7 & $2.9 \mathrm{E}+02$ & ND & ND & $4.8 \mathrm{E}+01$ & $3.1 \mathrm{E}+02$ & $\begin{array}{c}1.9 \mathrm{E}+02 \\
{[1.50 \mathrm{E}+02]}\end{array}$ & $\begin{array}{c}7.2 \mathrm{E}-01 \\
{[1.62]}\end{array}$ \\
\hline & 7 & $2.8 \mathrm{E}+02$ & ND & ND & $5.0 \mathrm{E}+01$ & $2.8 \mathrm{E}+02$ & $\begin{array}{c}2.5 \mathrm{E}+02 \\
{[1.92 \mathrm{E}+02]}\end{array}$ & $\begin{array}{c}8.4 \mathrm{E}-01 \\
{[1.87]}\end{array}$ \\
\hline & 14 & $2.0 \mathrm{E}+02$ & ND & ND & $3.6 \mathrm{E}+01$ & $2.1 \mathrm{E}+02$ & $\begin{array}{c}1.2 \mathrm{E}+01 \\
{[9.0]}\end{array}$ & $\begin{array}{c}9.8 \mathrm{E}-02 \\
{[0.22]}\end{array}$ \\
\hline & 14 & $2.0 \mathrm{E}+02$ & ND & ND & $3.7 \mathrm{E}+01$ & $1.9 \mathrm{E}+02$ & $\begin{array}{c}2.6 \mathrm{E}+01 \\
{[2.1 \mathrm{E}+01]}\end{array}$ & $\begin{array}{c}1.0 \mathrm{E}-01 \\
{[0.23]}\end{array}$ \\
\hline & 28 & $2.1 \mathrm{E}-01$ & ND & ND & $3.4 \mathrm{E}-02$ & $7.8 \mathrm{E}+01$ & $\begin{array}{c}\mathrm{ND} \\
{[<1.1 \mathrm{E}+01]}\end{array}$ & $\begin{array}{c}1.2 \mathrm{E}-01 \\
{[0.28]}\end{array}$ \\
\hline & 28 & $1.8 \mathrm{E}-01$ & ND & ND & 4.0E-02 & $1.1 \mathrm{E}+02$ & $\begin{array}{c}\mathrm{ND} \\
{[<1.1 \mathrm{E}+01]}\end{array}$ & $\begin{array}{c}1.2 \mathrm{E}-01 \\
{[0.26]}\end{array}$ \\
\hline & 42 & 7.1E-02 & ND & ND & $2.4 \mathrm{E}-02$ & $5.9 \mathrm{E}+01$ & $\begin{array}{c}\mathrm{ND} \\
{[<1.1 \mathrm{E}+01]}\end{array}$ & $\begin{array}{c}8.7 \mathrm{E}-02 \\
{[0.20]}\end{array}$ \\
\hline & 42 & 7.3E-02 & ND & ND & $2.3 \mathrm{E}-02$ & $6.1 \mathrm{E}+01$ & $\begin{array}{c}\mathrm{ND} \\
{[<1.1 \mathrm{E}+01]}\end{array}$ & $\begin{array}{c}8.7 \mathrm{E}-02 \\
{[0.19]}\end{array}$ \\
\hline & 49 & $1.8 \mathrm{E}-02$ & ND & ND & $8.2 \mathrm{E}-03$ & $2.0 \mathrm{E}+01$ & $\begin{array}{c}\mathrm{ND} \\
{[<1.1 \mathrm{E}+01]}\end{array}$ & $\begin{array}{c}4.7 \mathrm{E}-02 \\
{[0.10]}\end{array}$ \\
\hline & 49 & $1.9 \mathrm{E}-02$ & ND & ND & 8.3E-03 & $2.0 \mathrm{E}+01$ & $\begin{array}{c}\mathrm{ND} \\
{[<1.1 \mathrm{E}+01]}\end{array}$ & $\begin{array}{c}4.7 \mathrm{E}-02 \\
{[0.10]}\end{array}$ \\
\hline & 63 & $2.0 \mathrm{E}-02$ & ND & ND & $1.2 \mathrm{E}-02$ & $2.9 \mathrm{E}+01$ & $\begin{array}{c}\mathrm{ND} \\
{[<1.1 \mathrm{E}+01]}\end{array}$ & $\begin{array}{c}8.2 \mathrm{E}-02 \\
{[0.18]}\end{array}$ \\
\hline & 63 & $2.1 \mathrm{E}-02$ & ND & ND & $1.2 \mathrm{E}-02$ & $2.9 \mathrm{E}+01$ & $\begin{array}{c}\mathrm{ND} \\
{[<1.1 \mathrm{E}+01]}\end{array}$ & $\begin{array}{c}7.0 \mathrm{E}-02 \\
{[0.16]}\end{array}$ \\
\hline
\end{tabular}

(a) $\mathrm{PO}_{4}{ }^{3-}$ and $\mathrm{SO}_{4}{ }^{2-}$ were also calculated based on phophorus and sulfur concentrations analyzed by ICP-OES.

(b) ND indicates "not detected"; below quantification level

(c) Percentage of leaching (\%) is also shown in bracket, [ ], below measured concentrations ( $\mathrm{mg} / \mathrm{L})$. Because of low concentration of spiked iodine, leaching percentage of iodide was calculated based on the instrumental MDL. 


\subsection{Discussion}

Release of ${ }^{99} \mathrm{Tc},{ }^{127} \mathrm{I}$, and RCRA metals from Cast Stone and Geopolymer may proceed by a series of sequential or simultaneous competing chemical and physical reactions or processes that control mass transfer of these elements from the waste form to the surrounding solution. These reactions and processes include, but are not limited to, the following:

- diffusion/advection

- dissolution/precipitation

- adsorption/absorption/desorption

- oxidation/reduction

- paragenetic sequence of mineral transformation.

The overall impact of individual or coupled reactions and processes on the release of COCs depends on a number of variables, such as the waste form composition, materials' resistance to physical and chemical degradation, dominant mechanism controlling release, and experimental conditions. However, under the short-term test conditions discussed in this report, it is assumed that diffusion plays a key role in the release process, especially under the conditions evaluated in EPA Draft Method 1315.

The calculated diffusivity and LI are displayed in Table 6.1 through Table 6.3. For Cast Stone, all diffusivity and LI values for arsenic, cadmium, copper, ${ }^{127} \mathrm{I}$, and lead represent maximum values. These values were calculated using the detection limit at the leachate concentrations at each leach interval for which no mass was detected. The detection limit represents the maximum concentration that can be expected to be in solution. After 14 days of testing, the average diffusivity for sodium and ${ }^{99} \mathrm{Tc}$ release from Cast Stone was $7.0( \pm 0.8) \times 10^{-11} \mathrm{~cm}^{2} / \mathrm{s}$ and $3.0( \pm 0.4) \times 10^{-13} \mathrm{~cm}^{2} / \mathrm{s}$, respectively. The diffusivity values for sodium and ${ }^{99} \mathrm{Tc}$ results in average LIs of 10.2 and 12.5 , respectively, and suggest that Cast Stone is performing well in these experiments. The technetium LI is higher than that reported for Cast Stone (LI 9.4 to 10.3) with a LAW simulant waste stream (Lockrem 2005). The higher LI for the secondary waste stimulant may be due to the high waste loading in the waste form used in the LAW tests.

Unlike Cast Stone, the diffusivity for a number of the RCRA metals was quantifiable for both Geopolymer samples and ranged between an LI of 9.7 and 17.1 for samples that had measureable concentration of selected RCRA metals. For sodium and ${ }^{99} \mathrm{Tc}$ release from Geopolymer at day 14, the average LI ranged between 8.33 and 10.5 for batch \#1 and 8.3 and 10.5 for batch \#2, respectively. These values are consistent with those reported for sodium (8.6) and rhenium (10.4) using the ANS 16.1 procedure in an earlier study of Geopolymer immobilization of a secondary waste stream (Russell et al. 2006). In general, both the Cast Stone and Geopolymer are performing well in these experiments with Cast Stone demonstrating slightly better performance at this stage of testing. 
Table 6.1. The Diffusivity and Leachability Index for $\mathrm{Cd}, \mathrm{Cr}$, and $\mathrm{Pb}$ in Eluate for Waste Forms from EPA Method 1315

\begin{tabular}{|c|c|c|c|c|c|c|c|}
\hline Waste Form & $\begin{array}{l}\text { Cumulative } \\
\text { Leaching Time } \\
\text { (Days) }\end{array}$ & $\begin{array}{l}\text { Cd Diffusivity } \\
\left(\mathrm{cm}^{2} / \mathrm{s}\right)\end{array}$ & LI & $\begin{array}{c}\text { Cr Diffusivity } \\
\left(\mathrm{cm}^{2} / \mathrm{s}\right)\end{array}$ & LI & $\begin{array}{c}\mathrm{Pb} \text { Diffusivity } \\
\left(\mathrm{cm}^{2} / \mathrm{s}\right)\end{array}$ & LI \\
\hline \multirow{18}{*}{ Cast Stone } & 0.08 & $<4.57 \mathrm{E}-12$ & 11.3 & $<1.91 \mathrm{E}-12$ & 11.7 & $<2.89 \mathrm{E}-13$ & 12.5 \\
\hline & 0.08 & $<4.13 \mathrm{E}-12$ & 11.4 & $<1.73 \mathrm{E}-12$ & 11.8 & $<2.61 \mathrm{E}-13$ & 12.6 \\
\hline & 1 & $<7.55 \mathrm{E}-13$ & 12.1 & $<3.16 \mathrm{E}-13$ & 12.5 & $<4.77 \mathrm{E}-14$ & 13.3 \\
\hline & 1 & $<6.82 \mathrm{E}-13$ & 12.2 & $<2.86 \mathrm{E}-13$ & 12.5 & $<4.31 \mathrm{E}-14$ & 13.4 \\
\hline & 2 & $<2.38 \mathrm{E}-12$ & 11.6 & $<9.98 \mathrm{E}-13$ & 12.0 & $<1.51 \mathrm{E}-13$ & 12.8 \\
\hline & 2 & $<2.16 \mathrm{E}-12$ & 11.7 & $<9.03 \mathrm{E}-13$ & 12.0 & $<1.36 \mathrm{E}-13$ & 12.9 \\
\hline & 7 & $<2.44 \mathrm{E}-13$ & 12.6 & $1.37 \mathrm{E}-13$ & 12.9 & $<1.54 \mathrm{E}-14$ & 13.8 \\
\hline & 7 & $<2.20 \mathrm{E}-13$ & 12.7 & $<9.23 \mathrm{E}-14$ & 13.0 & $<1.39 \mathrm{E}-14$ & 13.9 \\
\hline & 14 & $<3.18 \mathrm{E}-13$ & 12.5 & $<1.33 \mathrm{E}-13$ & 12.9 & $<2.01 \mathrm{E}-14$ & 13.7 \\
\hline & 14 & $<2.84 \mathrm{E}-13$ & 12.5 & $<1.19 \mathrm{E}-13$ & 12.9 & $<1.80 \mathrm{E}-14$ & 13.7 \\
\hline & 28 & $<1.58 \mathrm{E}-13$ & 12.8 & $<6.62 \mathrm{E}-14$ & 13.2 & $<9.99 \mathrm{E}-15$ & 14.0 \\
\hline & 28 & $<1.43 \mathrm{E}-13$ & 12.8 & $<5.99 \mathrm{E}-14$ & 13.2 & $<9.04 \mathrm{E}-15$ & 14.0 \\
\hline & 42 & $<2.67 \mathrm{E}-13$ & 12.6 & $<1.12 \mathrm{E}-13$ & 13.0 & $<1.69 \mathrm{E}-14$ & 13.8 \\
\hline & 42 & $<2.42 \mathrm{E}-13$ & 12.6 & $<1.01 \mathrm{E}-13$ & 13.0 & $5.99 \mathrm{E}-14$ & 13.2 \\
\hline & 49 & $<1.47 \mathrm{E}-12$ & 11.8 & $<6.17 \mathrm{E}-13$ & 12.2 & $<9.32 \mathrm{E}-14$ & 13.0 \\
\hline & 49 & $<1.33 \mathrm{E}-12$ & 11.9 & $<5.59 \mathrm{E}-13$ & 12.3 & $<8.44 \mathrm{E}-14$ & 13.1 \\
\hline & 63 & $<4.25 \mathrm{E}-13$ & 12.4 & $<1.78 \mathrm{E}-13$ & 12.7 & $<2.69 \mathrm{E}-14$ & 13.6 \\
\hline & 63 & $<3.84 \mathrm{E}-13$ & 12.4 & $<1.61 \mathrm{E}-13$ & 12.8 & $<2.43 \mathrm{E}-14$ & 13.6 \\
\hline \multirow{18}{*}{$\begin{array}{c}\text { Geopolymer } \\
\text { Batch \#1 }\end{array}$} & 0.08 & $<2.02 \mathrm{E}-10$ & 9.69 & $<3.37 \mathrm{E}-12$ & 11.5 & $<1.81 \mathrm{E}-13$ & 12.7 \\
\hline & 0.08 & $<2.01 \mathrm{E}-10$ & 9.70 & $<3.35 \mathrm{E}-12$ & 11.5 & $<1.80 \mathrm{E}-13$ & 12.7 \\
\hline & 1 & $<3.29 \mathrm{E}-11$ & 10.5 & $<5.49 \mathrm{E}-13$ & 12.3 & $<2.96 \mathrm{E}-14$ & 13.5 \\
\hline & 1 & $<3.27 \mathrm{E}-11$ & 10.5 & $<5.46 \mathrm{E}-13$ & 12.3 & $<2.94 \mathrm{E}-14$ & 13.5 \\
\hline & 2 & $<9.99 \mathrm{E}-11$ & 10.0 & $<1.67 \mathrm{E}-12$ & 11.8 & $<8.97 \mathrm{E}-14$ & 13.0 \\
\hline & 2 & $<9.91 \mathrm{E}-11$ & 10.0 & $<1.65 \mathrm{E}-12$ & 11.8 & $<8.90 \mathrm{E}-14$ & 13.1 \\
\hline & 7 & $<1.10 \mathrm{E}-11$ & 11.0 & $5.13 \mathrm{E}-13$ & 12.3 & $<9.90 \mathrm{E}-15$ & 14.0 \\
\hline & 7 & $<1.10 \mathrm{E}-11$ & 11.0 & $4.50 \mathrm{E}-13$ & 12.3 & $<9.84 \mathrm{E}-15$ & 14.0 \\
\hline & 14 & $<1.39 \mathrm{E}-11$ & 10.9 & $1.35 \mathrm{E}-12$ & 11.9 & $4.54 \mathrm{E}-13$ & 12.3 \\
\hline & 14 & $<1.38 \mathrm{E}-11$ & 10.9 & $1.21 \mathrm{E}-12$ & 11.9 & $4.39 \mathrm{E}-13$ & 12.4 \\
\hline & 28 & $<6.98 \mathrm{E}-12$ & 11.2 & $9.50 \mathrm{E}-13$ & 12.0 & $4.53 \mathrm{E}-13$ & 12.3 \\
\hline & 28 & $<6.93 \mathrm{E}-12$ & 11.2 & $9.62 \mathrm{E}-13$ & 12.0 & $4.89 \mathrm{E}-13$ & 12.3 \\
\hline & 42 & $<1.21 \mathrm{E}-11$ & 10.9 & $2.20 \mathrm{E}-12$ & 11.7 & $5.02 \mathrm{E}-13$ & 12.3 \\
\hline & 42 & $<1.20 \mathrm{E}-11$ & 10.9 & $1.64 \mathrm{E}-12$ & 11.8 & $5.61 \mathrm{E}-13$ & 12.3 \\
\hline & 49 & $<6.11 \mathrm{E}-11$ & 10.2 & 4.37E-12 & 11.4 & $7.65 \mathrm{E}-13$ & 12.1 \\
\hline & 49 & $<6.07 \mathrm{E}-11$ & 10.2 & $4.85 \mathrm{E}-12$ & 11.3 & $7.60 \mathrm{E}-13$ & 12.1 \\
\hline & 63 & $<1.94 \mathrm{E}-11$ & 10.7 & $2.35 \mathrm{E}-12$ & 11.6 & $2.87 \mathrm{E}-13$ & 12.5 \\
\hline & 63 & $<1.93 \mathrm{E}-11$ & 10.7 & $2.42 \mathrm{E}-12$ & 11.6 & 7.19E-13 & 12.1 \\
\hline
\end{tabular}


Table 6.1. (contd)

\begin{tabular}{|c|c|c|c|c|c|c|c|}
\hline Waste Form & $\begin{array}{c}\text { Cumulative } \\
\text { Leaching Time } \\
\text { (Days) }\end{array}$ & $\begin{array}{c}\text { Cd Diffusivity } \\
\left(\mathrm{cm}^{2} / \mathrm{s}\right)\end{array}$ & LI & $\begin{array}{c}\text { Cr Diffusivity } \\
\left(\mathrm{cm}^{2} / \mathrm{s}\right)\end{array}$ & LI & $\begin{array}{c}\mathrm{Pb} \text { Diffusivity } \\
\left(\mathrm{cm}^{2} / \mathrm{s}\right)\end{array}$ & LI \\
\hline \multirow{18}{*}{$\begin{array}{c}\text { Geopolymer } \\
\text { Batch \#2 }\end{array}$} & 0.08 & $<1.79 \mathrm{E}-10$ & 9.75 & 4.28E-11 & 10.4 & $<2.02 \mathrm{E}-13$ & 12.7 \\
\hline & 0.08 & $<2.00 \mathrm{E}-10$ & 9.70 & $6.21 \mathrm{E}-11$ & 10.2 & $<2.26 \mathrm{E}-13$ & 12.6 \\
\hline & 1 & $<2.57 \mathrm{E}-11$ & 10.6 & $3.15 \mathrm{E}-11$ & 10.5 & $<2.90 \mathrm{E}-14$ & 13.5 \\
\hline & 1 & $<2.88 \mathrm{E}-11$ & 10.5 & $4.80 \mathrm{E}-11$ & 10.3 & $<3.26 \mathrm{E}-14$ & 13.5 \\
\hline & 2 & $<7.39 \mathrm{E}-11$ & 10.1 & $5.00 \mathrm{E}-11$ & 10.3 & $<8.35 \mathrm{E}-14$ & 13.1 \\
\hline & 2 & $<8.29 \mathrm{E}-11$ & 10.1 & $7.99 \mathrm{E}-11$ & 10.1 & $<9.37 \mathrm{E}-14$ & 13.0 \\
\hline & 7 & $<9.14 \mathrm{E}-12$ & 11.0 & $8.68 \mathrm{E}-13$ & 12.1 & $<1.03 \mathrm{E}-14$ & 14.0 \\
\hline & 7 & $<1.02 \mathrm{E}-11$ & 11.0 & $1.58 \mathrm{E}-12$ & 11.8 & $<1.16 \mathrm{E}-14$ & 13.9 \\
\hline & 14 & $<1.14 \mathrm{E}-11$ & 10.9 & $1.32 \mathrm{E}-12$ & 11.9 & $1.23 \mathrm{E}-13$ & 12.9 \\
\hline & 14 & $<1.28 \mathrm{E}-11$ & 10.9 & $1.31 \mathrm{E}-12$ & 11.9 & $1.02 \mathrm{E}-13$ & 13.0 \\
\hline & 28 & $<5.77 \mathrm{E}-12$ & 11.2 & $1.10 \mathrm{E}-12$ & 12.0 & $2.08 \mathrm{E}-13$ & 12.7 \\
\hline & 28 & $<6.47 \mathrm{E}-12$ & 11.2 & $1.38 \mathrm{E}-12$ & 11.9 & $1.74 \mathrm{E}-13$ & 12.8 \\
\hline & 42 & $<9.46 \mathrm{E}-12$ & 11.0 & $1.41 \mathrm{E}-12$ & 11.8 & $1.60 \mathrm{E}-13$ & 12.8 \\
\hline & 42 & $<1.06 \mathrm{E}-11$ & 11.0 & $1.86 \mathrm{E}-12$ & 11.7 & $2.14 \mathrm{E}-13$ & 12.7 \\
\hline & 49 & $<5.14 \mathrm{E}-11$ & 10.3 & $2.72 \mathrm{E}-12$ & 11.6 & $2.73 \mathrm{E}-13$ & 12.6 \\
\hline & 49 & $<5.77 \mathrm{E}-11$ & 10.2 & $2.84 \mathrm{E}-12$ & 11.5 & $4.77 \mathrm{E}-13$ & 12.3 \\
\hline & 63 & $<1.56 \mathrm{E}-11$ & 10.8 & $1.78 \mathrm{E}-12$ & 11.7 & $3.86 \mathrm{E}-13$ & 12.4 \\
\hline & 63 & $<1.75 \mathrm{E}-11$ & 10.8 & $2.27 \mathrm{E}-12$ & 11.6 & $3.15 \mathrm{E}-13$ & 12.5 \\
\hline
\end{tabular}


Table 6.2. The Diffusivity and Leachability Index for $\mathrm{Ag}$ and $\mathrm{Hg}$ in Eluate for Waste Forms from EPA Method 1315

\begin{tabular}{|c|c|c|c|c|c|}
\hline Waste Form & $\begin{array}{l}\text { Cumulative Leaching Time } \\
\text { (Days) }\end{array}$ & $\begin{array}{l}\text { Ag Diffusivity } \\
\left(\mathrm{cm}^{2} / \mathrm{s}\right)\end{array}$ & LI & $\begin{array}{l}\text { Hg Diffusivity } \\
\left(\mathrm{cm}^{2} / \mathrm{s}\right)\end{array}$ & LI \\
\hline \multirow{18}{*}{ Cast Stone } & 0.08 & $<2.63 \mathrm{E}-11$ & 10.6 & $<2.34 \mathrm{E}-09$ & 8.63 \\
\hline & 0.08 & $<2.38 \mathrm{E}-11$ & 10.6 & $<2.12 \mathrm{E}-09$ & 8.67 \\
\hline & 1 & $<4.35 \mathrm{E}-12$ & 11.4 & $<3.87 \mathrm{E}-10$ & 9.41 \\
\hline & 1 & $<3.93 \mathrm{E}-12$ & 11.4 & $<3.50 \mathrm{E}-10$ & 9.46 \\
\hline & 2 & $<1.37 \mathrm{E}-11$ & 10.9 & $<1.22 \mathrm{E}-09$ & 8.91 \\
\hline & 2 & $<1.24 \mathrm{E}-11$ & 10.9 & $<1.10 \mathrm{E}-09$ & 8.96 \\
\hline & 7 & $<1.40 \mathrm{E}-12$ & 11.9 & $<1.25 \mathrm{E}-10$ & 9.90 \\
\hline & 7 & $<1.27 \mathrm{E}-12$ & 11.9 & $<1.13 \mathrm{E}-10$ & 9.95 \\
\hline & 14 & $<1.83 \mathrm{E}-12$ & 11.7 & $<1.63 \mathrm{E}-10$ & 9.79 \\
\hline & 14 & $<1.64 \mathrm{E}-12$ & 11.8 & $<1.46 \mathrm{E}-10$ & 9.84 \\
\hline & 28 & $<9.10 \mathrm{E}-13$ & 12.0 & $<8.09 \mathrm{E}-11$ & 10.1 \\
\hline & 28 & $<8.23 \mathrm{E}-13$ & 12.1 & $<7.32 \mathrm{E}-11$ & 10.1 \\
\hline & 42 & $<1.54 \mathrm{E}-12$ & 11.8 & $<1.37 \mathrm{E}-10$ & 9.86 \\
\hline & 42 & $<1.39 \mathrm{E}-12$ & 11.9 & $<1.24 \mathrm{E}-10$ & 9.91 \\
\hline & 49 & $<8.49 \mathrm{E}-12$ & 11.1 & $<7.55 \mathrm{E}-10$ & 9.12 \\
\hline & 49 & $<7.68 \mathrm{E}-12$ & 11.1 & $<6.83 \mathrm{E}-10$ & 9.17 \\
\hline & 63 & $<2.45 \mathrm{E}-12$ & 11.6 & $<2.18 \mathrm{E}-10$ & 9.66 \\
\hline & 63 & $<2.21 \mathrm{E}-12$ & 11.7 & $<1.97 \mathrm{E}-10$ & 9.71 \\
\hline \multirow{18}{*}{$\begin{array}{c}\text { Geopolymer } \\
\text { Batch \#1 }\end{array}$} & 0.08 & $<2.17 \mathrm{E}-16$ & 15.7 & $<8.07 \mathrm{E}-11$ & 10.1 \\
\hline & 0.08 & $<2.16 \mathrm{E}-16$ & 15.7 & $<8.03 \mathrm{E}-11$ & 10.1 \\
\hline & 1 & $<3.54 \mathrm{E}-17$ & 16.5 & $<1.32 \mathrm{E}-11$ & 10.9 \\
\hline & 1 & $<3.52 \mathrm{E}-17$ & 16.5 & $<1.31 \mathrm{E}-11$ & 10.9 \\
\hline & 2 & $<1.07 \mathrm{E}-16$ & 16.0 & $1.08 \mathrm{E}-10$ & 9.96 \\
\hline & 2 & $<1.07 \mathrm{E}-16$ & 16.0 & $1.29 \mathrm{E}-10$ & 9.89 \\
\hline & 7 & $<1.19 \mathrm{E}-17$ & 16.9 & $<4.41 \mathrm{E}-12$ & 11.4 \\
\hline & 7 & $<1.18 \mathrm{E}-17$ & 16.9 & $<4.38 \mathrm{E}-12$ & 11.4 \\
\hline & 14 & $<1.50 \mathrm{E}-17$ & 16.8 & $<5.56 \mathrm{E}-12$ & 11.3 \\
\hline & 14 & $<1.49 \mathrm{E}-17$ & 16.8 & $2.98 \mathrm{E}-11$ & 10.5 \\
\hline & 28 & $<7.51 \mathrm{E}-18$ & 17.1 & $<2.79 \mathrm{E}-12$ & 11.6 \\
\hline & 28 & $<7.46 \mathrm{E}-18$ & 17.1 & $3.04 \mathrm{E}-11$ & 10.5 \\
\hline & 42 & $<1.30 \mathrm{E}-17$ & 16.9 & $<4.83 \mathrm{E}-12$ & 11.3 \\
\hline & 42 & $<1.29 \mathrm{E}-17$ & 16.9 & $<4.80 \mathrm{E}-12$ & 11.3 \\
\hline & 49 & $<6.58 \mathrm{E}-17$ & 16.2 & $<2.44 \mathrm{E}-11$ & 10.6 \\
\hline & 49 & $<6.53 \mathrm{E}-17$ & 16.2 & $5.32 \mathrm{E}-11$ & 10.3 \\
\hline & 63 & $<2.09 \mathrm{E}-17$ & 16.7 & $<7.77 \mathrm{E}-12$ & 11.1 \\
\hline & 63 & $<2.08 \mathrm{E}-17$ & 16.7 & $2.36 \mathrm{E}-11$ & 10.6 \\
\hline
\end{tabular}


Table 6.2. (contd)

\begin{tabular}{|c|c|c|c|c|c|}
\hline Waste Form & $\begin{array}{l}\text { Cumulative Leaching Time } \\
\text { (Days) }\end{array}$ & $\begin{array}{c}\text { Ag Diffusivity } \\
\left(\mathrm{cm}^{2} / \mathrm{s}\right)\end{array}$ & LI & $\begin{array}{l}\mathrm{Hg} \text { Diffusivity } \\
\left(\mathrm{cm}^{2} / \mathrm{s}\right)\end{array}$ & LI \\
\hline \multirow{18}{*}{$\begin{array}{l}\text { Geopolymer } \\
\text { Batch } \# 2\end{array}$} & 0.08 & $<3.48 \mathrm{E}-16$ & 15.5 & $<3.11 \mathrm{E}-11$ & 10.5 \\
\hline & 0.08 & $<3.90 \mathrm{E}-16$ & 15.4 & $<3.49 \mathrm{E}-11$ & 10.5 \\
\hline & 1 & $<5.00 \mathrm{E}-17$ & 16.3 & $<4.47 \mathrm{E}-12$ & 11.3 \\
\hline & 1 & $<5.61 \mathrm{E}-17$ & 16.3 & $<5.01 \mathrm{E}-12$ & 11.3 \\
\hline & 2 & $<1.44 \mathrm{E}-16$ & 15.8 & $<1.29 \mathrm{E}-11$ & 10.9 \\
\hline & 2 & $<1.61 \mathrm{E}-16$ & 15.8 & $<1.44 \mathrm{E}-11$ & 10.8 \\
\hline & 7 & $<1.78 \mathrm{E}-17$ & 16.7 & $1.64 \mathrm{E}-12$ & 11.8 \\
\hline & 7 & $<1.99 \mathrm{E}-17$ & 16.7 & $1.94 \mathrm{E}-12$ & 11.7 \\
\hline & 14 & $<2.22 \mathrm{E}-17$ & 16.7 & $<1.99 \mathrm{E}-12$ & 11.7 \\
\hline & 14 & $<2.49 \mathrm{E}-17$ & 16.6 & $<2.23 \mathrm{E}-12$ & 11.7 \\
\hline & 28 & $<1.12 \mathrm{E}-17$ & 16.9 & $<1.00 \mathrm{E}-12$ & 12.0 \\
\hline & 28 & $<1.26 \mathrm{E}-17$ & 16.9 & $<1.13 \mathrm{E}-12$ & 11.9 \\
\hline & 42 & $<1.84 \mathrm{E}-17$ & 16.7 & $<1.65 \mathrm{E}-12$ & 11.8 \\
\hline & 42 & $<2.07 \mathrm{E}-17$ & 16.7 & $<1.85 \mathrm{E}-12$ & 11.7 \\
\hline & 49 & $<1.00 \mathrm{E}-16$ & 16.0 & $<8.95 \mathrm{E}-12$ & 11.0 \\
\hline & 49 & $<1.12 \mathrm{E}-16$ & 15.9 & $<1.00 \mathrm{E}-11$ & 11.0 \\
\hline & 63 & $<3.04 \mathrm{E}-17$ & 16.5 & $<2.71 \mathrm{E}-12$ & 11.6 \\
\hline & 63 & $<3.41 \mathrm{E}-17$ & 16.5 & $<3.05 \mathrm{E}-12$ & 11.5 \\
\hline
\end{tabular}


Table 6.3. The Diffusivity and Leachability Index for ${ }^{127} \mathrm{I},{ }^{99} \mathrm{Tc}$, and $\mathrm{Na}$ in Eluate for Waste Forms from EPA Method $1315^{\text {(a) }}$

\begin{tabular}{|c|c|c|c|c|c|c|c|}
\hline Waste Form & $\begin{array}{c}\text { Cumulative Leaching } \\
\text { Time (Days) }\end{array}$ & $\begin{array}{l}{ }^{127} \mathrm{I} \text { Diffusivity } \\
\left(\mathrm{cm}^{2} / \mathrm{s}\right)\end{array}$ & LI & $\begin{array}{c}{ }^{99} \mathrm{Tc} \text { Diffusivity } \\
\left(\mathrm{cm}^{2} / \mathrm{s}\right)\end{array}$ & LI & $\begin{array}{l}\text { Na Diffusivity } \\
\left(\mathrm{cm}^{2} / \mathrm{s}\right)\end{array}$ & LI \\
\hline \multirow{18}{*}{ Cast Stone } & 0.08 & $1.21 \mathrm{E}-04$ & 3.92 & $1.20 \mathrm{E}-11$ & 10.9 & $2.56 \mathrm{E}-09$ & 8.59 \\
\hline & 0.08 & $1.63 \mathrm{E}-04$ & 3.79 & $7.65 \mathrm{E}-12$ & 11.1 & 2.39E-09 & 8.62 \\
\hline & 1 & $<2.76 \mathrm{E}-07$ & 6.56 & $1.44 \mathrm{E}-12$ & 11.8 & $1.55 \mathrm{E}-10$ & 9.81 \\
\hline & 1 & $<2.50 \mathrm{E}-07$ & 6.60 & $1.10 \mathrm{E}-12$ & 12.0 & $1.76 \mathrm{E}-10$ & 9.76 \\
\hline & 2 & $1.24 \mathrm{E}-05$ & 4.91 & $<1.01 \mathrm{E}-12$ & 12.0 & 1.04E-10 & 10.0 \\
\hline & 2 & 4.54E-05 & 4.34 & $<9.14 \mathrm{E}-13$ & 12.0 & $9.91 \mathrm{E}-11$ & 10.0 \\
\hline & 7 & $<8.92 \mathrm{E}-08$ & 7.05 & $4.29 \mathrm{E}-13$ & 12.4 & 7.32E-11 & 10.1 \\
\hline & 7 & $<8.06 \mathrm{E}-08$ & 7.09 & $3.30 \mathrm{E}-13$ & 12.5 & $6.79 \mathrm{E}-11$ & 10.2 \\
\hline & 14 & 6.41E-07 & 6.19 & $2.69 \mathrm{E}-13$ & 12.6 & 7.54E-11 & 10.1 \\
\hline & 14 & $1.02 \mathrm{E}-06$ & 5.99 & $3.23 \mathrm{E}-13$ & 12.5 & $6.42 \mathrm{E}-11$ & 10.2 \\
\hline & 28 & $<1.44 \mathrm{E}-08$ & 7.84 & $2.75 \mathrm{E}-13$ & 12.6 & $5.79 \mathrm{E}-11$ & 10.2 \\
\hline & 28 & $8.60 \mathrm{E}-11$ & 10.1 & $2.28 \mathrm{E}-13$ & 12.6 & 4.76E-11 & 10.3 \\
\hline & 42 & $<9.77 \mathrm{E}-08$ & 7.01 & $2.84 \mathrm{E}-13$ & 12.5 & $4.57 \mathrm{E}-11$ & 10.3 \\
\hline & 42 & $<8.84 \mathrm{E}-08$ & 7.05 & $3.30 \mathrm{E}-13$ & 12.5 & $4.31 \mathrm{E}-11$ & 10.4 \\
\hline & 49 & $<5.39 \mathrm{E}-07$ & 6.27 & $<6.25 \mathrm{E}-13$ & 12.2 & $5.28 \mathrm{E}-11$ & 10.3 \\
\hline & 49 & $<4.88 \mathrm{E}-07$ & 6.31 & $<5.65 \mathrm{E}-13$ & 12.2 & $4.51 \mathrm{E}-11$ & 10.3 \\
\hline & 63 & $<1.55 \mathrm{E}-07$ & 6.81 & $6.62 \mathrm{E}-13$ & 12.2 & $4.75 \mathrm{E}-11$ & 10.3 \\
\hline & 63 & $<1.41 \mathrm{E}-07$ & 6.85 & $5.78 \mathrm{E}-13$ & 12.2 & 3.79E-11 & 10.4 \\
\hline \multirow{18}{*}{$\begin{array}{l}\text { Geopolymer } \\
\text { Batch \#1 }\end{array}$} & 0.08 & $<4.75 \mathrm{E}-07$ & 6.32 & $3.13 \mathrm{E}-11$ & 10.5 & $1.5 \mathrm{E}-09$ & 8.81 \\
\hline & 0.08 & $4.38 \mathrm{E}-05$ & 4.36 & $1.72 \mathrm{E}-10$ & 9.76 & 2.1E-09 & 8.68 \\
\hline & 1 & 4.71E-05 & 4.33 & $1.82 \mathrm{E}-11$ & 10.7 & 2.1E-09 & 8.67 \\
\hline & 1 & 4.92E-05 & 4.31 & $3.61 \mathrm{E}-11$ & 10.4 & 2.9E-09 & 8.54 \\
\hline & 2 & 7.77E-06 & 5.11 & $3.88 \mathrm{E}-11$ & 10.4 & $3.8 \mathrm{E}-09$ & 8.43 \\
\hline & 2 & $1.23 \mathrm{E}-05$ & 4.91 & $4.95 \mathrm{E}-11$ & 10.3 & $4.9 \mathrm{E}-09$ & 8.31 \\
\hline & 7 & $6.79 \mathrm{E}-06$ & 5.17 & $3.78 \mathrm{E}-11$ & 10.4 & $3.2 \mathrm{E}-09$ & 8.49 \\
\hline & 7 & 7.69E-06 & 5.11 & $8.22 \mathrm{E}-11$ & 10.1 & 4.5E-09 & 8.35 \\
\hline & 14 & $<3.27 \mathrm{E}-08$ & 7.49 & $1.89 \mathrm{E}-11$ & 10.7 & 4.7E-09 & 8.33 \\
\hline & 14 & $7.39 \mathrm{E}-08$ & 7.13 & $5.23 \mathrm{E}-11$ & 10.3 & $4.8 \mathrm{E}-09$ & 8.32 \\
\hline & 28 & $6.83 \mathrm{E}-08$ & 7.17 & $9.85 \mathrm{E}-12$ & 11.0 & 3.0E-09 & 8.52 \\
\hline & 28 & $<6.52 \mathrm{E}-08$ & 7.19 & $2.68 \mathrm{E}-11$ & 10.6 & $2.8 \mathrm{E}-09$ & 8.55 \\
\hline & 42 & $<1.14 \mathrm{E}-07$ & 6.94 & $7.74 \mathrm{E}-12$ & 11.1 & 2.3E-09 & 8.64 \\
\hline & 42 & $<1.13 \mathrm{E}-07$ & 6.95 & $1.48 \mathrm{E}-11$ & 10.8 & 2.2E-09 & 8.67 \\
\hline & 49 & $<5.75 \mathrm{E}-07$ & 6.24 & $7.21 \mathrm{E}-12$ & 11.1 & 2.1E-09 & 8.68 \\
\hline & 49 & $<5.71 \mathrm{E}-07$ & 6.24 & $1.25 \mathrm{E}-11$ & 10.9 & 2.2E-09 & 8.66 \\
\hline & 63 & $<1.83 \mathrm{E}-07$ & 6.74 & $3.76 \mathrm{E}-12$ & 11.4 & 1.4E-09 & 8.85 \\
\hline & 63 & $<1.82 \mathrm{E}-07$ & 6.74 & $8.87 \mathrm{E}-12$ & 11.1 & 1.4E-09 & 8.85 \\
\hline
\end{tabular}


Table 6.3. (contd)

\begin{tabular}{|c|c|c|c|c|c|c|c|}
\hline Waste Form & $\begin{array}{c}\text { Cumulative } \\
\text { Leaching Time } \\
\text { (Days) }\end{array}$ & $\begin{array}{l}{ }^{127} \text { I Diffusivity } \\
\left(\mathrm{cm}^{2} / \mathrm{s}\right)\end{array}$ & LI & $\begin{array}{c}{ }^{99} \mathrm{Tc} \\
\text { Diffusivity } \\
\left(\mathrm{cm}^{2} / \mathrm{s}\right)\end{array}$ & LI & $\begin{array}{l}\text { Na Diffusivity } \\
\left(\mathrm{cm}^{2} / \mathrm{s}\right)\end{array}$ & LI \\
\hline \multirow{18}{*}{$\begin{array}{c}\text { Geopolymer } \\
\text { Batch \#2 }\end{array}$} & 0.08 & $3.94 \mathrm{E}-06$ & 5.40 & $2.53 \mathrm{E}-09$ & 8.60 & $3.95 \mathrm{E}-09$ & 8.40 \\
\hline & 0.08 & $2.21 \mathrm{E}-06$ & 5.65 & $3.58 \mathrm{E}-09$ & 8.45 & 4.79E-09 & 8.32 \\
\hline & 1 & $2.38 \mathrm{E}-06$ & 5.62 & $2.87 \mathrm{E}-09$ & 8.54 & $3.08 \mathrm{E}-09$ & 8.51 \\
\hline & 1 & $1.63 \mathrm{E}-05$ & 4.79 & 4.27E-09 & 8.37 & $3.73 \mathrm{E}-09$ & 8.43 \\
\hline & 2 & $5.09 \mathrm{E}-06$ & 5.29 & $6.32 \mathrm{E}-09$ & 8.20 & $4.96 \mathrm{E}-09$ & 8.30 \\
\hline & 2 & $2.43 \mathrm{E}-05$ & 4.61 & $9.93 \mathrm{E}-09$ & 8.00 & $5.70 \mathrm{E}-09$ & 8.24 \\
\hline & 7 & $1.04 \mathrm{E}-05$ & 4.98 & $1.22 \mathrm{E}-09$ & 8.91 & $5.32 \mathrm{E}-09$ & 8.27 \\
\hline & 7 & $1.92 \mathrm{E}-05$ & 4.72 & $1.82 \mathrm{E}-09$ & 8.74 & $5.77 \mathrm{E}-09$ & 8.24 \\
\hline & 14 & $4.70 \mathrm{E}-08$ & 7.33 & $2.81 \mathrm{E}-11$ & 10.6 & 4.24E-09 & 8.37 \\
\hline & 14 & $2.75 \mathrm{E}-07$ & 6.56 & $3.58 \mathrm{E}-11$ & 10.4 & $5.48 \mathrm{E}-09$ & 8.26 \\
\hline & 28 & $<3.37 \mathrm{E}-08$ & 7.47 & $2.28 \mathrm{E}-11$ & 10.6 & $3.38 \mathrm{E}-09$ & 8.47 \\
\hline & 28 & $<3.78 \mathrm{E}-08$ & 7.42 & $2.22 \mathrm{E}-11$ & 10.7 & $3.25 \mathrm{E}-09$ & 8.49 \\
\hline & 42 & $<5.53 \mathrm{E}-08$ & 7.26 & $1.83 \mathrm{E}-11$ & 10.7 & $2.06 \mathrm{E}-09$ & 8.69 \\
\hline & 42 & $<6.20 \mathrm{E}-08$ & 7.21 & $2.02 \mathrm{E}-11$ & 10.7 & $2.25 \mathrm{E}-09$ & 8.65 \\
\hline & 49 & $<3.01 \mathrm{E}-07$ & 6.52 & $2.87 \mathrm{E}-11$ & 10.5 & $2.18 \mathrm{E}-09$ & 8.66 \\
\hline & 49 & $<3.37 \mathrm{E}-07$ & 6.47 & $3.21 \mathrm{E}-11$ & 10.5 & 2.60E-09 & 8.59 \\
\hline & 63 & $<9.11 \mathrm{E}-08$ & 7.04 & $2.66 \mathrm{E}-11$ & 10.6 & $1.23 \mathrm{E}-09$ & 8.91 \\
\hline & 63 & $<1.02 \mathrm{E}-07$ & 6.99 & $2.18 \mathrm{E}-11$ & 10.7 & $1.52 \mathrm{E}-09$ & 8.82 \\
\hline
\end{tabular}

(a) ND indicates "not detected"; below quantification level. Because of low concentration of spiked iodine, leaching percentage of iodide was calculated based on the instrumental MDL. For ND values, sample MDL was used to calculate diffusivity (in table with $<$ ).

To date, the results presented in Section 5.0 suggest release of ${ }^{99} \mathrm{Tc},{ }^{127} \mathrm{I}$, and RCRA metals are lower for Cast Stone than Geopolymer. Although the monoliths from the Method 1315 tests have not been analyzed, the solution chemistry data, combined with the results obtained from EPA Draft Method 1313 and Method 1316, provide some insight into reasons why lower releases of COCs $\left({ }^{99} \mathrm{Tc},{ }^{127} \mathrm{I}\right.$, and RCRA metals) from Cast Stone versus Geopolymer were observed. There are at least two plausible explanations for the lower diffusive release. The first plausible hypothesis is associated with physical changes to the Cast Stone pore structure resulting from calcite precipitation. For example, XRD analyses of postleached crushed samples from EPA Method 1313 revealed that the relative amount of calcite increased after 24 hours of contact at $\mathrm{pH}\left(23^{\circ} \mathrm{C}\right)=12$. Figure 6.1 shows a plot of the calcite intensity for the 28 -day cured samples. A similar alkaline $\mathrm{pH}$ condition also has been observed over the duration of the 1315 experiments with Cast Stone. Furthermore, geochemical calculations suggest that the solution sample collected on Day 14 for the 1315 experiments is supersaturated with respect to calcite (saturation index = 1.49). The precipitation of a secondary mineral such as calcite on the surface of the waste form can have an impact on the release of all the COCs. 

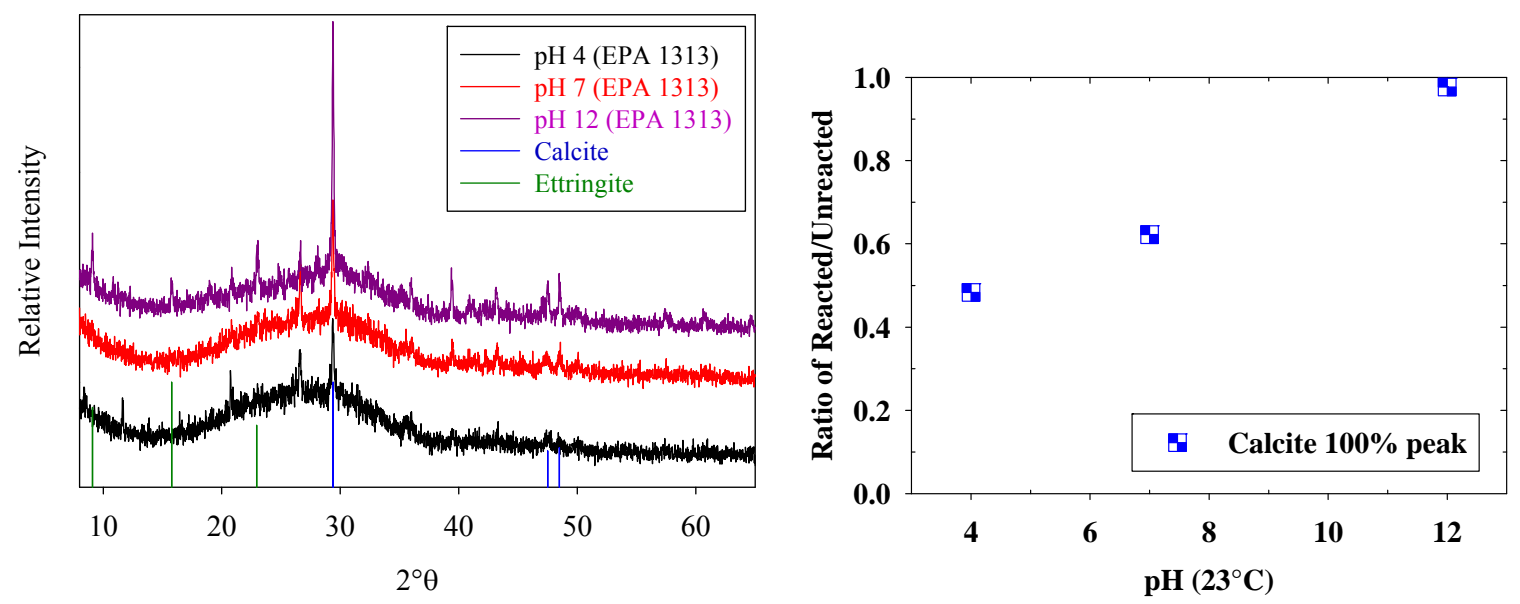

Figure 6.1. XRD Pattern of Reacted Cast Stone at $\mathrm{pH}\left(23^{\circ} \mathrm{C}\right)=4.0,7.0$, and 12.0 from EPA Method 1313 (left) and Change in Calcite 100 Percent as a Function of pH (right)

In addition to physical changes caused by secondary mineral formation of major constituents in a waste form, the release of the COCs from Cast Stone also can be affected by the precipitation of a solubility limited phase. For example, RCRA metals (such as cadmium) typically form oxide and oxyhydroxide phases at high $\mathrm{pH}$. These phases tend to limit the dissolved concentration of these contaminants for long periods of time. At this stage of the testing program, it is unclear which of these processes is the dominant mechanism controlling the release of COCs. However, based on the results collected to date, Cast Stone and Geopolymer appear to be viable immobilization options for WTP secondary waste. 


\subsection{Conclusions and Recommendations}

Screening tests are being conducted to evaluate waste forms for the immobilization of secondary liquid wastes from the Hanford Tank Waste and Immobilization Plant. The addition of a stabilization treatment unit to the ETF is planned to provide the needed capacity for treating these wastes from WTP. The current baseline is to use a Cast Stone cementitious waste form for the solidification of the wastes. Through a literature survey, Duralith alkali-alumino-silicate geopolymer, FBSR granular product encapsulated in a geopolymer matrix, and a Ceramicrete phosphate bonded ceramic were identified both as candidate waste forms and alternatives to the baseline. These wastes forms have been shown to meet waste disposal acceptance criteria, including compressive strength and universal treatment standards for RCRA metals (as measured by the TCLP). Thus these non-cementitious wast forms should also be acceptable for land disposal. Previous testing reported in the literature indicated there were some formulation issues that needed to be addressed for the Duralith and Ceramicrete waste forms, and information is needed on all four waste forms with respect to their ability to minimize the release of technetium. Technetium is a radionuclide predicted to be in the secondary liquid wastes in small quantities but the IDF risk assessment analyses shows technetium even at low mass to have the largest contribution to the estimated IDF disposal impacts to groundwater.

To support a final waste form down selection, PNNL is conducting screening tests on the candidate waste forms to provide a basis for comparison and to resolve the formulation issues and data needs identified in the literature review. This report documents the screening test results on the cementitious Cast Stone and alkali alumino-silicate Geopolymer waste forms. Screening tests on the Ceramicrete phosphate bonded ceramic and encapsulated FBSR material will be conducted and documented as those materials become available. Later, more comprehensive and longer-term performance testing will be conducted, following the guidance provided by the secondary waste form selection, development, and performance evaluation roadmap. Ultimately either one or a few waste forms will be chosen in a down selection process. The down-selected waste form(s) will be compliant to regulations and performance criteria and will lead to cost-effective disposal of the WTP secondary wastes.

Three of the four draft test protocols (e.g., 1313, 1315, and 1316) being developed for EPA were used to screen the Cast Stone and Geopolymer stabilization technologies. Method 1314 may be used in the Phase of testing.

- EPA Draft Method 1313 - Leaching Test (Liquid-Solid Partitioning as a Function of Extract pH) of Constituents in Solid Materials Using a Parallel Batch Extraction Test (EPA 2009a)

- EPA Draft Method 1314 — Leaching Test (Liquid-Solid Partitioning as a Function of Liquid-to-Solid Ratio) of Constituents in Solid Materials Using Up-Flow Percolation Column (EPA 2009b)

- EPA Draft Method 1315-Mass Transfer Rates of Constituents in Monolith or Compacted Granular Materials Using a Semi-Dynamic Tank Leaching Test (EPA 2009c)

- EPA Draft Method 1316 - Leaching Test (Liquid-Solid Partitioning as a Function of Liquid-to-Solid Ratio) of Constituents in Solid Materials Using a Parallel Batch Extraction Test (EPA 2009d).

The EPA Draft Methods are a combination of static, column, and semi-dynamic leach experiments that can be used to provide more detailed mechanistic information on material performance in comparison to the current standard leach methods, such as ANSI 16.1 and TCLP. The EPA Draft Method 1313 is a 
static-leach test method where nine parallel extraction experiments are conducted in dilute acid or base with DI water at a fixed $\mathrm{pH}$ and liquid-to-solid ratio. Instead of a dilute acid or base at a fixed liquid-tosolid ratio, Draft Method 1316 uses DI water as the leachant. EPA Draft Method 1314 is column leach experiment that consists of contacting a granular solid material with water as a function of liquid-to-solid ratio under flow-through conditions. At each of the nine pre-determined leaching intervals the leaching solution is collected and the sample mass is recorded. The EPA Draft Method 1315 is a 63-day semidynamic leach experiment that consists of submerging a monolithic sample (with a fixed geometry) in water at a fixed liquid-to-solid ratio for a fixed period of time. At each of the nine pre-determined leaching intervals, the sample mass is recorded, and the leachant is changed. This method is similar to ANSI/ANS 16.1, but the intervals are different. The leachate solutions collected from each of the test methods are analyzed to determine the 1) $\mathrm{pH}, 2$ ) electrical conductivity, 3) concentration of specific dissolved components, and 4) redox conditions.

For the screening tests, 4-inch by 2-inch diameter cylinders of the Cast Stone and Geopolymer were prepared from a secondary waste stream simulant spiked with technetium-99. For consistency, the waste loading in both waste forms was at a prescribed $8 \mathrm{wt} \%$ solids on a dry basis using a simulant at $2 \mathrm{M}$ sodium. The simulant composition was representative of the secondary liquid wastes to be treated and solidified in the ETF. These wastes are composed of liquid wastes from the caustic scrubber in the LAW vitrification facility and evaporator condensates from the pretreatment plant. The caustic scrubber is downstream of the primary LAW vitrification off-gas treatment system and is expected to capture volatile iodine and technetium not removed earlier in the process. As part of the secondary off-gas treatment system, the caustic scrubber is downstream of the HEPA filters used for particulate removal, the carbon beds for mercury removal, and the selective catalytic reduction beds for oxidizing volatile organic compounds $\mathrm{SO}_{\mathrm{x}}$ and carbon monoxide and for $\mathrm{NO}_{\mathrm{x}}$ reduction. The caustic scrubber liquid effluents are returned to the pretreatment plant where they are combined with the pretreatment evaporator condensates and sent to the LERF/ETF, becoming the source of the secondary wastes requiring treatment.

Both the Cast Stone and Geopolymer appear to be viable waste forms for the solidification of the secondary liquid wastes to be treated in the ETF. This conclusion is based primarily on the diffusivity calculations for the release of technetium as determined by EPA Method 1315. The diffusivity for technetium from the Cast Stone monoliths was in the range of $1.2 \times 10^{-11}$ to $2.3 \times 10^{-13} \mathrm{~cm}^{2} / \mathrm{s}$ through the 63 days of testing. The diffusivity for technetium from the Geopolymer was in the range of $1.7 \times 10^{-10}$ to $3.8 \times 10^{-12} \mathrm{~cm}^{2} / \mathrm{s}$ through the 63 days of the test. These values compare with a target of $1 \times 10^{-9} \mathrm{~cm}^{2} / \mathrm{s}$ or less. The Geopolymer continues to show some fabrication issues with the diffusivities ranging from $1.7 \times$ $10^{-10}$ to $3.8 \times 10^{-12} \mathrm{~cm}^{2} / \mathrm{s}$ for the better-performing batch to from $1.2 \times 10^{-9}$ to $1.8 \times 10^{-11} \mathrm{~cm}^{2} / \mathrm{s}$ for the poorer-performing batch. However, through 63 days of immersion testing, the samples did not illustrate significant fracturing of the material as shown in Duralith samples from an earlier study of low temperature immobilization technologies.

In the EPA methods 1313 and 1316, the Cast Stone and Geopolymer showed similar leaching behavior. For both waste forms, the natural solution $\mathrm{pH}$ after soaking in DI water is approximately 12 . The alkaline solutions that result from leaching Cast Stone and Geopolymer suggests these waste forms may be suitable for a subsurface environment that has alkaline pore-water, similar to the IDF. Based on the fractions leached, iodide, technetium, mercury, and arsenic are more leachable than sodium and potassium, which are also more leachable than the waste form matrix materials silicon and aluminum. These results suggest the most leachable species reside predominantly in the pore water and that sodium and potassium, while partly in the pore water, are also bound within the structural matrix of the waste 
forms. As such, relatively high fraction releases for the technetium from the crushed waste form samples would be expected because of the large surface area and exposed pores. In the intact monoliths, the releases would be much slower because of the tortuosity factor between interconnected pores, the lower porosity and small pore throat sizes.

The waste forms were characterized with respect to their chemical and crystalline compositions. Both materials are largely amorphous. The Cast Stone is $>88 \mathrm{wt} \%$ amorphous with ettringite and calcite as the identified crystalline phases. The Geopolymer is $>70 \mathrm{wt} \%$ amorphous with quartz from the sand and fumed silica components as the identified crystalline phases. The dry materials used to develop each waste form also were characterized for chemical and crystalline composition. This information is available in the report to support design and safety analyses. The dry materials contain significant quantities of the hazardous RCRA metals, and, for some contaminants of concern, they are the largest contributor to the overall inventory.

The next phase of testing of the Cast Stone and Geopolymer will provide additional information about the waste form properties to support a final down selection to a waste form for the secondary waste streams. The Phase II testing will focus on three areas: 1) waste form development and optimization, 2) mechanisms of radionuclide retention, and 3) regulatory and waste acceptance testing.

Waste form development and optimization will focus on optimizing waste loading and evaluating the robustness of the waste form to waste stream variability. Activities to be conducted on the selected waste forms include:

- Optimizing the quantities of binder materials to improve waste loading. If acceptable, this may include the removal of water to concentrate the secondary liquid wastes to be immobilized.

- Evaluating the robustness of the waste form to waste stream composition variability

- Identifying impacts of process upsets, such as variation in waste-to-binder ratios and variation in dry binder-materials ratios

- Examining waste form porosity control during fabrication, including starting materials and starting material size.

The evaluation of the mechanism of radionuclide retention will provide some confidence that the waste performance observed in the short-term screening tests offer an indication of the long-term performance of the waste form in the disposal environment. An important aspect of waste form development is obtaining the data needed to support risk and performance assessments. Although the actual performance data to support the performance assessment will not be obtained until a final waste form selection, the results collected in this activity will focus on evaluating how changes to crucial geochemical and physical processes affect the release of key COCs (e.g., technetium, iodide, and RCRA metals). Geochemical processes testing will focus on obtaining some indication of the speciation of key COCs in both the solidified wastes and leachate solutions. The purpose of these analyses is to gain some indication of the oxidation state of redox-sensitive contaminants contained in these materials. For example, it is well known that technetium in the Tc(IV) oxidation state is less mobile than in the Tc(VII) oxidation state. The presence of components in the waste form dry materials that can change the redox state of these key COCs makes obtaining this type of information critical to understanding the potential for release from waste forms during weathering. Physical processes testing will focus on changes to the physical properties of the waste forms, namely porosity and pore-size distribution, which can have a 
significant impact on the movement of water, gas, COC, and other chemical constituents in and out of the waste form during weathering. This exchange is directly related to the number and size of pores and the microstructure of the material. Therefore, it is important to have some indication about how these changes occur during weathering. Furthermore, the precipitation of amorphous/crystalline alteration phases, such as calcite, can change the size, number, and distribution of pores within the microstructure.

Regulatory and waste acceptance testing will focus on obtaining waste form data to support waste disposal permitting and waste acceptance criteria. Wastes intended for disposal in IDF must meet requirements of DOE Order 435.1 and permit requirements established by the Washington State Department of Ecology. These requirements are captured in the waste acceptance criteria for IDF. Criteria, with respect to free liquids, compliance with land disposal restrictions, compressive strength, and leachability, are included.

Following a final waste form selection, the secondary waste form testing will be directed toward testing to support detailed design of the STU for IDF; data collection to support risk assessments and long-term performance assessments; and, as appropriate, further optimization of the waste form to reduce costs and improve performance. 


\subsection{References}

American Society for Testing and Materials (ASTM). 1998. "D2216-98 Standard Test Method for Laboratory Determination of Water (Moisture) Content of Soil and Rock by Mass." American Society for Testing and Materials. West Conshohocken, Pennsylvania.

ANSI, 1986. Measurement of the Leachability of Solidified Low Level Radioactive Waste by a ShortTerm Test Procedure. In: Institute, A. N. S. (Ed.). American Nuclear Society, La Grange Park, IL.

Brunauer S, PH Emmett, and E Teller. 1938. “Adsorption of Gases in Multimolecular Layers.” Journal of the American Chemical Society 60:309-319.

Cooke GA, LL Lockrem, BA Clark, and R Westburg, 2008. Cast Stone Technology for Treatment and Disposal of Iodine Rich Caustic Waste Demonstration-Final Report. RPP-RPT-26725, Rev 0-A, CH2M Hill Hanford Group, Inc., Richland, Washington.

Crank J. 1986. “Mathematics of Diffusion.” $2^{\text {nd }}$ ed. pp. 424. Oxford University Press, London.

Garrels, RM and CL Christ. 1965. Solutions, Minerals, and Equilibria. Freeman, Cooper and Co., San Francisco, California.

Koci GI. 2005. Conceptual Design Report for Effluent Treatment Facility Solidification Treatment Unit. Fluor Hanford, Richland, Washington.

Langmuir D. 1997. Aqueous Environmental Geochemistry. Prentice Hall, Upper Saddle River, New Jersey.

Lockrem LL. 2005. Hanford Containerized Cast Stone Facility Tank 1-Process Testing and Development Final Test Report. RPP-RPT-26742, Rev. 0. CH2M Hill, Richland, Washington.

Mann FM. 2002. Annual Summary of ILAW Performance Assessment for 2002. CH2M Hill Hanford Group, Inc., Richland, Washington.

Nordstrom DK and JL Munoz. 1985. Geochemical Thermodynamics. The Benjamin/Cummings Publishing Co., Inc., Menlo Park, California.

Pacific Northwest National Laboratory (PNNL). 1998. Inductively Coupled Plasma Mass Spectrometric (ICP-MS) Analysis. PNNL-AGG-415, Pacific Northwest National Laboratory, Richland, Washington.

Pacific Northwest National Laboratory (PNNL). 2006. Solubilization of metals from solids using a $\mathrm{KOH}-\mathrm{KNO}_{3}$ Fusion. PNNL-AGG-ESL-001, Pacific Northwest National Laboratory, Richland, Washington.

Pacific Northwest National Laboratory (PNNL). 2009a. Hanford Site Secondary Waste Roadmap. PNNL-18196, Pacific Northwest National Laboratory, Richland, Washington. 
Pacific Northwest National Laboratory (PNNL). 2009b. Operation of the MARS 5 microwave accelerated reaction system. PNNL-AGG-MARS-001, Pacific Northwest National Laboratory, Richland, Washington.

Pierce EM, SV Mattigod, RJ Serne, JP Icenhower, RD Scheele, W Um, N Qafoku, and JH Westsik, Jr. 2010. Review of Potential Candidate Stabilization Technologies for Liquid and Solid Secondary Waste Streams. PNNL-19122, Pacific Northwest National Laboratory, Richland, Washington.

Russell RL, MJ Schweiger, JH Westsik, PR Hrma, and DE Smith. 2006. Low Temperature Waste Immobilization Testing. PNNL-16052, Rev1. Pacific Northwest National Laboratory, Richland, Washington.

Strachan DM, HT Schaef, MJ Schweiger, KL Simmons, and LJ Woodcock. 2003. "A Versatile and Inexpensive XRD Specimen Holder for Highly Radioactive or Hazardous Specimens.” Powder Diffraction Journal 18:23-28.

U.S. Environmental Protection Agency (EPA). 1984. "Determination of Inorganic Anions." EPA Method 300.0A, in Test Method for the Determination of Inorganic Anions in Water by Ion Chromatography. EPA-600/4-84-0 17, U.S. Environmental Protection Agency, Washington, D.C.

U.S. Environmental Protection Agency (EPA). 1996. "Microwave Assisted Acid Digestion of Siliceous and Organically Based Matrices." EPA Method 3052, in Test Method for Evaluating Solid Waste, Physical/Chemical Methods. SW-846, U.S. Environmental Protection Agency, Washington, D.C.

U.S. Environmental Protection Agency (EPA). 2000a. "Inductively Coupled Plasma-Atomic Emission Spectrometry." EPA Method 6010B, in Test Methods for Evaluating Solid Waste, Physical/Chemical Methods. SW-846, U.S. Environmental Protection Agency, Washington, D.C. Accessed September 20, 2008 at http://www.epa.gov/epaoswer/hazwaste/test/sw846.htm.

U.S. Environmental Protection Agency (EPA). 2000b. "Inductively Coupled Plasma-Mass Spectrometry." EPA Method 6020, in Test Methods for Evaluating Solid Waste, Physical/Chemical Methods. SW-846, U.S. Environmental Protection Agency, Washington, D.C. Accessed September 20, 2008 at http://www.epa.gov/epaoswer/hazwaste/test/sw846.htm.

U.S. Environmental Protection Agency (EPA). 2009a. Leaching Test (Liquid-Solid Partitioning as a Function Liquid to Solid Ratio) of Constituents in Solid Materials Using a Parallel Batch Extraction Test. Draft Method 1313.

U.S. Environmental Protection Agency (EPA). 2009b. Leaching Test (Liquid-Solid Partitioning as a Function of Extract pH) of Constituents in Solid Materials Using a Parallel Batch Extraction Test. Draft Method 1316.

U.S. Environmental Protection Agency (EPA). 2009c. Mass Transfer Rates of Constituents in Monolith or Compacted Granular Materials Using a Semi-Dynamic Tank Leaching Test. Draft Method 1315. 
U.S. Geological Survey (USGS). 2004. "Alkalinity and Acid Neutralizing Capacity." In National Field Manual for the Collection of Water-Quality Data, Second Edition. Eds. SA Rounds and FD Wilde. Accessed September 20, 2008 at http://water.usgs.gov/owq/FieldManual/Chapter6/section6.6/html/section6.6.htm.

Washington State Department of Ecology, U.S. Environmental Protection Agency and U.S. Department of Energy (Ecology, EPA, and DOE). 1989. Hanford Facility Agreement and Consent Order, As Amended. Washington State Department of Ecology, U.S. Environmental Protection Agency, and U.S. Department of Energy, Olympia, Washington. 
Appendix A

Cast Stone Raw Materials 


\section{LaFarge}

Cement Test Report

cement

\begin{tabular}{|c|c|}
\hline MIIT Test Report Number: SEA_NEWCEM_OCTO9 \\
YEAR: 2009 \\
MONTH: October \\
PLANT: Seattle \\
CEMENT TYPE: Grade 100 NewCem \\
\hline
\end{tabular}

\begin{tabular}{|c|c|c|}
\hline \multicolumn{3}{|c|}{ Reference Cement } \\
\hline $\begin{array}{r}\text { Fineness by Air Permeability } \\
\left(\mathrm{m}^{2} / \mathrm{kg}: \text { ASTM C204) }\right.\end{array}$ & 389 & \\
\hline $\begin{array}{r}\text { Fineness by } 45 \mu \mathrm{m} \text { (No. 325) Sieve } \\
\text { (\% retain; ASTM C430) }\end{array}$ & 4.3 & \\
\hline $\begin{array}{r}\text { Compressive Strength } \\
\text { (ASTM C10a/C109 M) } \\
7 \text {-day } \\
\text { 28-day (previous month) }\end{array}$ & $\begin{array}{c}\text { psi } \\
4,901 \\
5,785\end{array}$ & \\
\hline & Actual & Max Limit \\
\hline $\begin{array}{r}\text { Total Alkalies }\left(\mathrm{Na}_{2} \mathrm{O}+0.658 \mathrm{~K}_{2} \mathrm{O}\right) \\
(\%, \mathrm{ASTM} \mathrm{C} 114)\end{array}$ & 0.88 & 0.8 \\
\hline
\end{tabular}

\begin{tabular}{|c|c|c|c|}
\hline \multicolumn{4}{|c|}{ Slag } \\
\hline $\begin{array}{l}\text { Fineness by Air Permeability } \\
\qquad\left(\mathrm{m}^{2} / \mathrm{kg} \text {. ASTM C204) }\right.\end{array}$ & 500 & & \\
\hline $\begin{array}{l}\text { Fineness by } 45 \mu \mathrm{m} \text { (No. 325) Sieve } \\
\text { (\% retain; ASTM C430) }\end{array}$ & 2.3 & & \\
\hline $\begin{array}{l}\text { Compressive Strength } \\
\text { (ASTM C100/C100 M) }\end{array}$ & & & $\begin{array}{l}\text { SAI Limit } \\
\text { Min }\end{array}$ \\
\hline & 4,379 & 80 & 75 \\
\hline 28-day (previous month) & 6,496 & 112 & \\
\hline \multirow{2}{*}{$\begin{array}{r}\text { Specific Gravity } \\
\left(M^{\prime} m^{3}: \text { ASTM C188) }\right.\end{array}$} & 289 & & \\
\hline & Actual & \multicolumn{2}{|c|}{ Max Limit } \\
\hline $\begin{array}{r}\text { Air Content of Mortar } \\
(\%, \text { ASTM C185) }\end{array}$ & $\overline{7.5}$ & & 12 \\
\hline $\begin{array}{l}\text { Sulfied Sulfur } \\
(\% \text { S, ASTM C114) }\end{array}$ & 0.7 & & 2.5 \\
\hline $\begin{array}{r}\text { Sulfate lon } \\
(\% \text { as SO3, ASTM C114) }\end{array}$ & 3.2 & & 4 \\
\hline
\end{tabular}

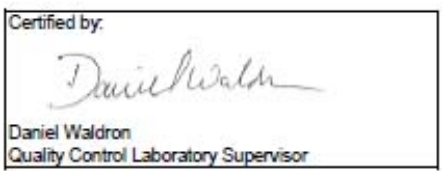

The ground granulated blast furmace slag complies with the current specification of the chemical physical requirement of ASTM C-.999, AASHTO M-302 for grade 100 Ground Granulated Blast Furace Slag (GGBFS). 


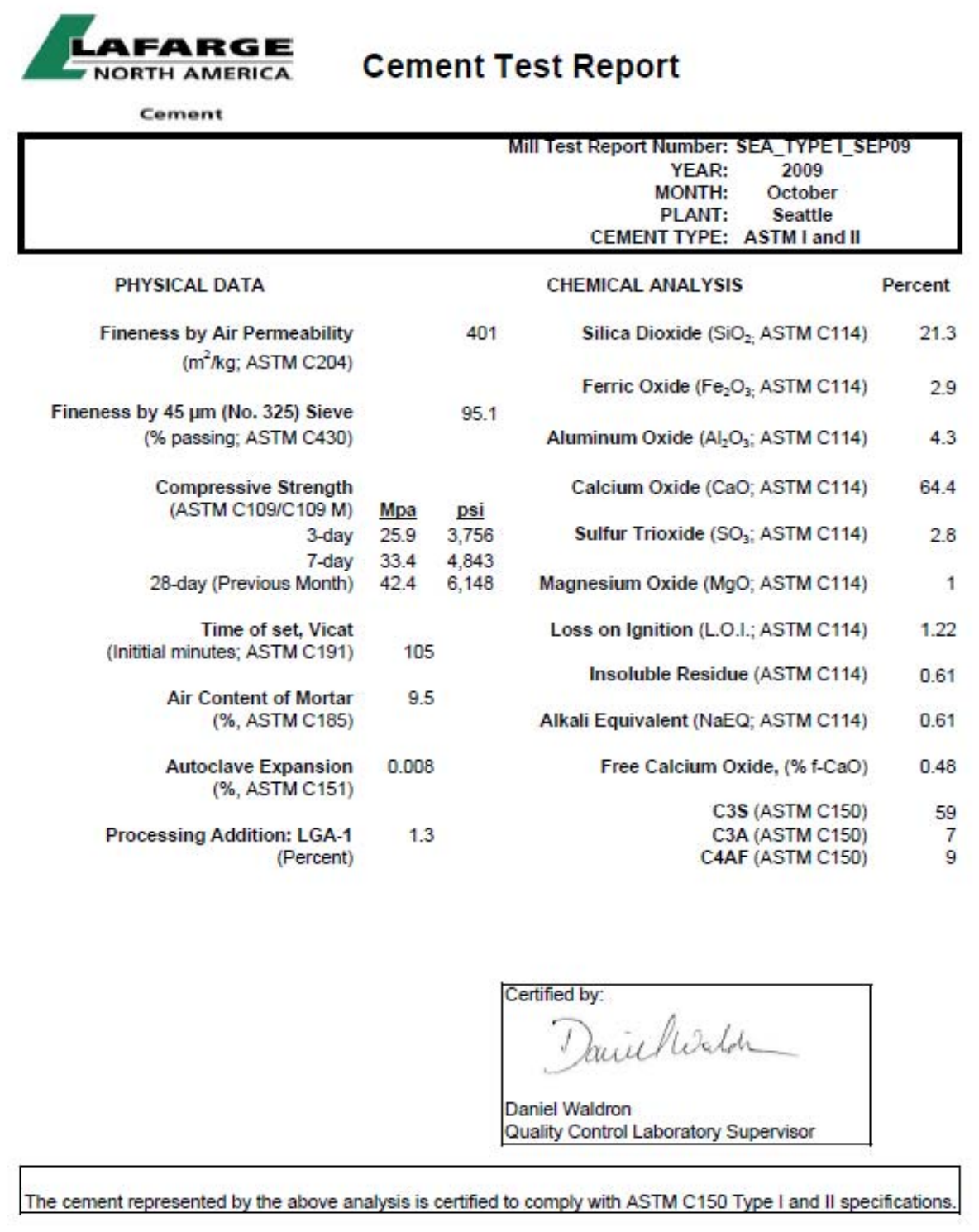




\section{Appendix B}

\section{Geopolymer Procedure Received from Catholic}

University of America 


\section{VSL PROCEDURE}

TITLE: $\quad$ Procedure for the Preparation of Geopolymer for PNNL Hanford Secondary Waste

DOCUMENT: TPI-GEOP Rev 0

Document Incorporated: None (New procedure)

Date Issued: 12/03/09

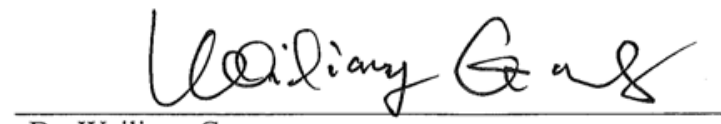

Dr. Weiliang Gong

Project Manager, VSL

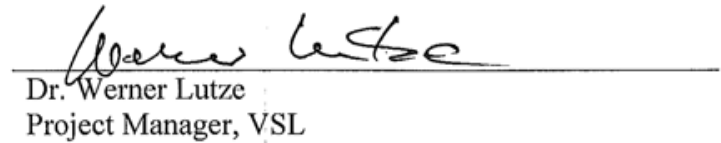

M Penabiel

Dr. Miguel Penafiel

Quality Assurance Administrator, VSL

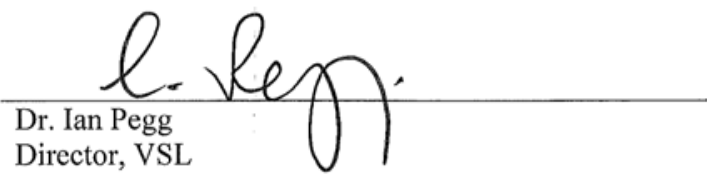

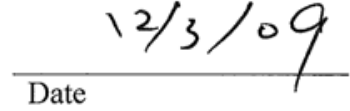

$12 / 3 / 09$

$\frac{12 / 3 / 09}{\text { Date }}$

$\frac{12 / 3 / 09}{\text { Date }}$ 
Table of Contents

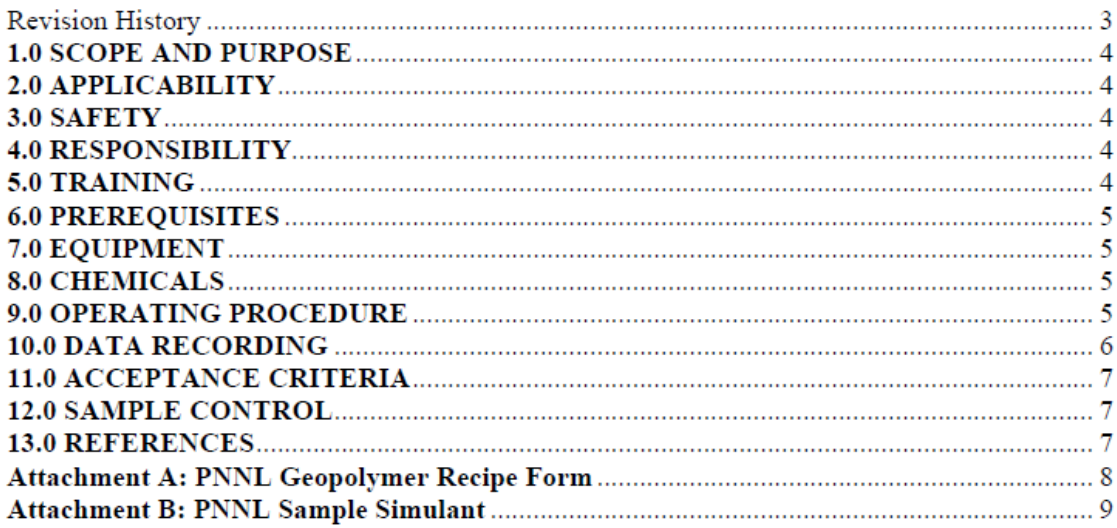


Vitreous State Laboratory

TPI-GEOP

Rev. \#0

Revision History
Issue Date: 12/03/09

Page 3 of 9

Rev\# Date Change

$0 \quad 12 / 03 / 09 \quad$ New procedure

B. 3 


\subsection{SCOPE AND PURPOSE}

1.1 This procedure describes the method for the preparation of geopolymer mixes that will incorporate PNNL HSW stimulant.

\subsection{APPLICABILITY}

2.1 This procedure applies exclusively to the preparation of geopolymer mixes that incorporate PNNL HSW (non-radioactive) simulant according to recipes provided by VSL scientists.

\subsection{SAFETY}

3.1 All specific safety issues will be reviewed by the VSL Project Leader with the staff that will be executing this procedure prior to engaging in activities described in this procedure. In particular, safety issues relating to chemical hazards, personnel safety and emergency procedures will be addressed.

3.2 All workers should be familiar with and have been trained on good laboratory practices and general laboratory safety.

3.2 Personal protective clothing and eye glasses should be worn at all times when handling hazardous materials.

3.3 All workers should be familiar with the location of fire extinguishers, fire alarms, first aid kits, emergency eye wash and shower stations, equipment power switches and circuit breaker panels.

3.4 All necessary measures pertaining to the use of radioactive materials must be followed in the event that such materials are used during the execution of this procedure.

\subsection{RESPONSIBILITY}

4.1 It is the responsibility of the VSL Project Advisor and the Laboratory Supervisor of the facility where this procedure is to be executed to provide sufficient guidance to the staff on the implementation of this procedure.

4.2 It is the responsibility of the Laboratory Supervisor of the facility where this procedure is to be executed to ensure that all staff members who use this procedure are properly trained in all aspects of its use.

\subsection{TRAINING}

5.1 All personnel assigned to work on activities associated with this procedure must be suitably trained to carry out such activities. The extent of training required and 
verification of such training is at the discretion of the Laboratory Supervisor of the facility where this procedure is to be executed.

\subsection{PREREQUISITES}

6.1 None

\subsection{EQUIPMENT}

7.1 Calibrated balances as needed.

7.2 Calibrated thermometer

7.3 1 to 5 gallon polyethelene container or equivalent to prepare the 'Activator Solution'.

7.4 Mixer (e.g. from Viking 7QT 1000 watt mixer)

7.5 Vibrating table (e.g. from Syntron model VP-261-D1)

\subsection{CHEMICALS}

8.1 As needed per prescribed recipes.

\subsection{OPERATING PROCEDURE}

\subsection{Preparation of Activator Solution}

Using the recipe provided in Attachment A, mix the required components in a suitable container in the following order:

Notes: - All components must be weighed with accuracy of $1 / 10^{\text {th }}$ of a gram. - A thermometer must be positioned in the mixing container to monitor the temperature of the mix.

9.1.1 Weigh the prescribed amount of HSW simulant (Attachment B: PNNL Sample Simulant) and add into the mixing container.

9.1.2 Weigh the prescribed amount of $\mathrm{SnF}_{2}$, add it to the mixing container and stir the mixture using a suitable mixing paddle for one hour.

9.1.3 Weigh the prescribed amount of $\mathrm{AgNO}_{3}$, add it to the mixing container and stir the mixture for one additional hour.

9.1.4 Weigh the prescribed amount of $\mathrm{KOH}$ and add it slowly to the mixing container until it is fully dissolved in the mix.

9.1.5 Weigh the prescribed amount of $\mathrm{NaOH}$ and add it slowly to the mixing container until it is fully dissolved.

Caution: Heat will be generated during dissolution of alkali hydroxide. Do not allow the solution temperature to exceed 65 degrees $C$

9.1.6 Weigh the prescribed amount of fumed silica and add it to the mixing container while stirring constantly.

a) Pour about $20 \mathrm{~g}$ each time and wait for fumed silica to dissolve.

9.1.7 Let the prepared mixture stand overnight. Cover with a suitable lid. 


\subsection{Preparation of the Binder}

Weigh and mix in a planetary mixer for about 5 minutes the following dry components: Metakaolin, Furnace slag, Sand, and Sodium sulfide hydrate (Order "6" in the Table of Attachment A). Let stand.

\subsection{Preparation of Geopolymer Paste}

Add the required components to the dry mixture in the planetary mixer as follows:

9.3.1 Pour the Activator Solution prepared in section 9.1 into the mixing container of the planetary mixer while operating the mixer at low speed. Set aside about $20 \mathrm{ml}$ of the Activator Solution for later use.

9.3.2 Increase the mixing speed and continue mixing until the paste becomes thinner.

9.3.3 If there is evidence of dry materials left on the bottom, stop mixing, raise the mixing paddle, pour the remaining $20 \mathrm{ml}$ reserved earlier near bottom and continue mixing. If it appears that more liquid is needed to homogenize the paste, pour up to $20 \mathrm{ml}$ water into the container which held the Activator Solution, rinse and pour into the mixer. If there is no evidence of dry material, just pour remaining $20 \mathrm{ml}$ while continuing to stir.

9.3.4 During mixing, sprinkle the ground Ag-zeolite (Order ' 7 ' in the table of Attachment A) into the mixing container so that it is incorporated into the mixing paste.

9.3.5 Continue mixing until the mixture turns into a smooth and homogeneous looking paste (no lumps left in the mix). The total mixing time from the beginning will be 5 to 10 minutes.

9.3.6 Transfer the paste into eight $2 "$ by 4 " cylindrical moulds as follows: Note: Vibrating table must be on while this step is executed

a) Add sufficient paste to fill a mould to about half of its capacity

b) Place on the vibrating table and wait for air bubbles to escape

c) Add more paste until full and wait again for air bubbles to escape.

d) Repeat for the other moulds.

Total time on the vibrating table is about 1 minute.

9.3.7 Cover each mould with plastic foil and pierce several small holes into the cover for ventilation.

9.3.8 Set moulds aside for 24 hours at room temperature.

9.3.9 Remove from moulds and set aside to dry in air overnight.

9.3.10 Place geopolymer cylinders in plastic bags and seal for 28 days.

\subsection{DATA RECORDING}

10.1 All activities associated with the execution of this procedure should be recorded in suitable laboratory notebooks. Any departures from this procedure that would affect properties of samples generated should also be adequately recorded. 


\subsection{ACCEPTANCE CRITERIA}

11.1 If conditions are not within normal limits determine cause if possible, and consult with the VSL Advisor for further instructions.

11.2 Samples prepared by following this procedure are considered valid samples that can undergo any kind of testing only after curing for 28 days.

\subsection{SAMPLE CONTROL}

12.1 All samples generated by this procedure should be properly labeled for tracking purposes. Established SOPs should be followed for this purpose.

\subsection{REFERENCES}

13.1 None 
Attachment A

\section{PNNL Geopolymer Recipe Form}

\begin{tabular}{|c|c|c|c|}
\hline Logbook: & & Requested By: & W. Gong \\
\hline Reference Logbook: & & Date: & $12 / 2 / 2009$ \\
\hline Recipe ID: & NT6PNL & Task \#: & V000 \\
\hline
\end{tabular}

\begin{tabular}{|c|c|c|c|l|l|l|l|}
\hline Order & Chemical & Target Weight $(\mathbf{g})$ & Assay & I.D. & Actual Weight $(\mathbf{g})$ & Balance\# & Date and Initial \\
\hline $\mathbf{6}$ & Metakaolin & $\mathbf{8 1 3 . 3}$ & 0.960 & & & & \\
\hline $\mathbf{4}$ & $\mathrm{KOH}$ & $\mathbf{4 1 1 . 4}$ & 0.900 & & & & \\
\hline $\mathbf{4}$ & $\mathrm{NaOH}$ & $\mathbf{2 0 . 1}$ & 0.980 & & & & \\
\hline $\mathbf{5}$ & Fumed silica, activator & $\mathbf{4 6 3 . 8}$ & 0.946 & & & & \\
\hline $\mathbf{6}$ & Furnace slag & $\mathbf{5 3 4 . 2}$ & 1.000 & & & & \\
\hline $\mathbf{6}$ & Sand & $\mathbf{7 5 9 . 5}$ & 1.000 & & & & \\
\hline $\mathbf{1}$ & HSW simulant & $\mathbf{7 9 8 . 5}$ & 1.000 & & & & \\
\hline $\mathbf{3}$ & AgNO3 & $\mathbf{3 . 0}$ & 0.99 & & & & \\
\hline $\mathbf{2}$ & SnF2 & $\mathbf{3 . 0}$ & 0.98 & & & & \\
\hline $\mathbf{6}$ & Sodium sulfide hydrate & $\mathbf{5 . 0}$ & 0.99 & & & & \\
\hline $\mathbf{7}$ & Ground Ag-zeolite & $\mathbf{2 0 . 0}$ & 0.99 & & & & \\
\hline
\end{tabular}


Attachment B: PNNL Sample Simulant

Hanford Secondary Waste - New Composition (Target density $1.108 \mathrm{~g} / \mathrm{mL}$ )

\begin{tabular}{|r|r|r|r|}
\hline Logbook: & & Requested by: & Wei Gong \\
\hline Reference Logbook: & & Date: & $12 / 2 / 2009$ \\
\hline Recipe ID: & NT6PNLS & Task \#: & V000 \\
\hline
\end{tabular}

\begin{tabular}{|c|c|c|c|c|c|c|c|c|c|c|c|c|}
\hline \multirow{2}{*}{$\begin{array}{l}\text { Order of } \\
\text { Addition }\end{array}$} & \multirow{2}{*}{ Analyte } & Target & \multirow{2}{*}{ Reagent } & \multirow{2}{*}{$\begin{array}{c}\text { Molecular } \\
\text { Weight }\end{array}$} & \multirow{2}{*}{$\begin{array}{c}\begin{array}{c}\text { Target } \\
\text { Wt }\end{array} \\
1 \mathrm{~L}(\mathrm{~g})\end{array}$} & \multirow{2}{*}{ Assay } & \multirow{2}{*}{$\begin{array}{c}\text { Target } \\
\begin{array}{c}\text { Weight } \\
(\mathrm{g})\end{array} \\
\end{array}$} & \multirow{2}{*}{ CUA\# } & \multirow{2}{*}{ Location } & \multirow{2}{*}{$\begin{array}{c}\begin{array}{c}\text { Actual } \\
\text { Weight }\end{array} \\
\text { (g) }\end{array}$} & \multirow{2}{*}{ Balance\# } & \multirow{2}{*}{$\begin{array}{l}\text { Date and } \\
\text { Initials }\end{array}$} \\
\hline & & (M) & & & & & & & & & & \\
\hline 1 & $\mathrm{Ag}$ & $2.50 \mathrm{E}-04$ & $\mathrm{AgNO} 3$ & 169.89 & 0.042 & 0.99 & 0.031 & & & & & \\
\hline 1 & \multirow{2}{*}{ Al } & $1.39 \mathrm{E}-01$ & $\mathrm{Al}((\mathrm{NO} 3) 3 * 9 \mathrm{H} 2 \mathrm{O}$ & 375.13 & 52.180 & 0.99 & 37.899 & & & & & \\
\hline 1 & & $9.09 \mathrm{E}-02$ & $\mathrm{Al} 2 \mathrm{O} 3$ & 101.96128 & 4.634 & 0.99 & 3.366 & & & & & \\
\hline 1 & $\mathrm{Cd}$ & $5.00 \mathrm{E}-05$ & $\mathrm{Cd}(\mathrm{NO} 3) 2.4 \mathrm{H} 2 \mathrm{O}$ & 308.48 & 0.015 & 0.99 & 0.011 & & & & & \\
\hline 1 & $\mathrm{CO} 3$ & $1.50 \mathrm{E}-06$ & $\mathrm{Na} 2 \mathrm{CO}_{3}$ & 106 & 0.000 & 0.99 & 0.000 & & & & & \\
\hline 1 & $\mathrm{Cr}_{\mathrm{r}}$ & $3.70 \mathrm{E}-04$ & $\mathrm{Cr}(\mathrm{NO} 3) 3.9 \mathrm{H} 2 \mathrm{O}$ & 400.15 & 0.148 & 0.99 & 0.108 & & & & & \\
\hline 1 & $\mathrm{Hg}$ & $3.30 \mathrm{E}-05$ & $\mathrm{Hg}(\mathrm{NO} 3) 2 . \mathrm{H} 2 \mathrm{O}$ & 342.62 & 0.011 & 0.98 & 0.008 & & & & & \\
\hline 1 & $\mathrm{P}$ & $1.70 \mathrm{E}-02$ & $\mathrm{Na} 3 \mathrm{PO} 4 * 12 \mathrm{H} 2 \mathrm{O}$ & 380.12096 & 6.462 & 0.99 & 4.693 & & & & & \\
\hline 1 & $\mathrm{~s}$ & $9.70 \mathrm{E}-03$ & $\mathrm{Na} 2 \mathrm{SO} 4$ & 142.0376 & 1.378 & 0.99 & 1.001 & & & & & \\
\hline 1 & NO3 & $6.90 \mathrm{E}-01$ & $\mathrm{NaNO}_{3}$ & 84.99471 & 22.914 & 0.99 & 16.643 & & & & & \\
\hline \multirow[t]{2}{*}{1} & $\mathrm{OH}$ & $1.20 \mathrm{E}+00$ & $\mathrm{NaOH}$ & 40.01 & 48.012 & 0.98 & 35.227 & & & & & \\
\hline & $\mathrm{Na}$ & $2.00 \mathrm{E}+00$ & (Na) & & & & & & & & & \\
\hline 1 & $\mathrm{~Pb}$ & $7.90 \mathrm{E}-04$ & $\mathrm{~Pb}(\mathrm{NO} 3) 2$ & 331.21 & 0.262 & 0.99 & 0.190 & & & & & \\
\hline 1 & TOC & $2.30 \mathrm{E}-01$ & $\mathrm{Na} 2 \mathrm{C} 2 \mathrm{O} 4$ & 134 & 30.820 & 0.98 & 22.613 & & & & & \\
\hline 1 & I & $2.90 \mathrm{E}-06$ & $\mathrm{NaI}(100 \mathrm{mg} / \mathrm{L} \mathrm{I})$ & & 0.000 & 0.99 & 0.086 & & & & & \\
\hline 3 & $\operatorname{Re}$ & $6.00 \mathrm{E}-07$ & $\begin{array}{c}\mathrm{HReO} 4(100 \mathrm{mg} / \mathrm{L} \\
\mathrm{Re})\end{array}$ & & 0.000 & 0.50 & 0.194 & & & & & \\
\hline \multirow[t]{2}{*}{2} & $\mathrm{H} 2 \mathrm{O}^{*}$ & 52.2401000 & $\mathrm{H} 2 \mathrm{O}$ & 18.01528 & 941.120 & & 676.705 & - & & & & \\
\hline & & & Total $(\mathrm{g} / \mathrm{L})$ & & 1108.000 & & 798.496 & & & & & \\
\hline
\end{tabular}


Appendix C

\section{X-ray Diffraction Patterns}




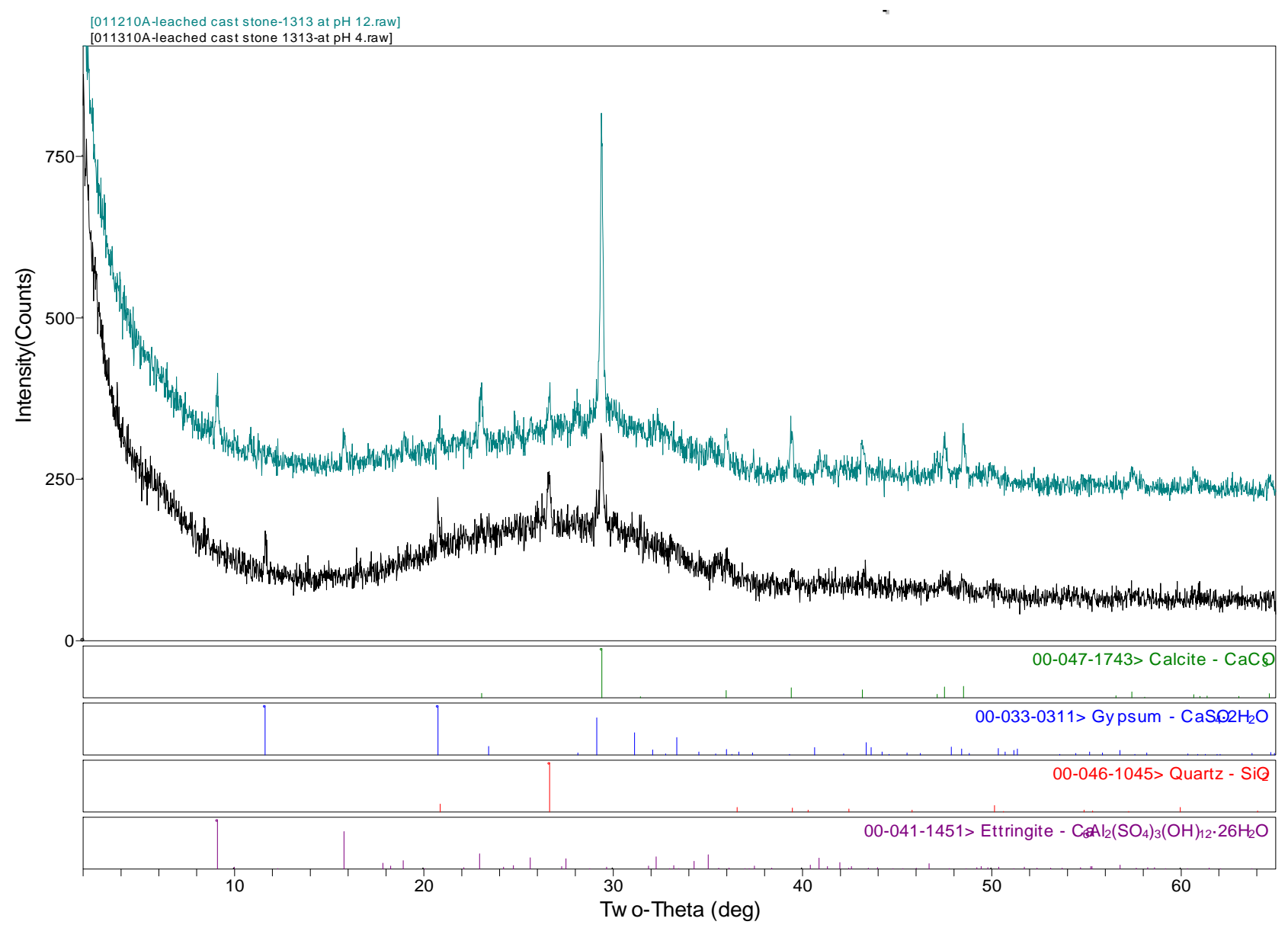

Figure C.1. EPA Method $1313 \mathrm{pH}\left(23^{\circ} \mathrm{C}\right)=4.0$ and 12.0 for Cast Stone 


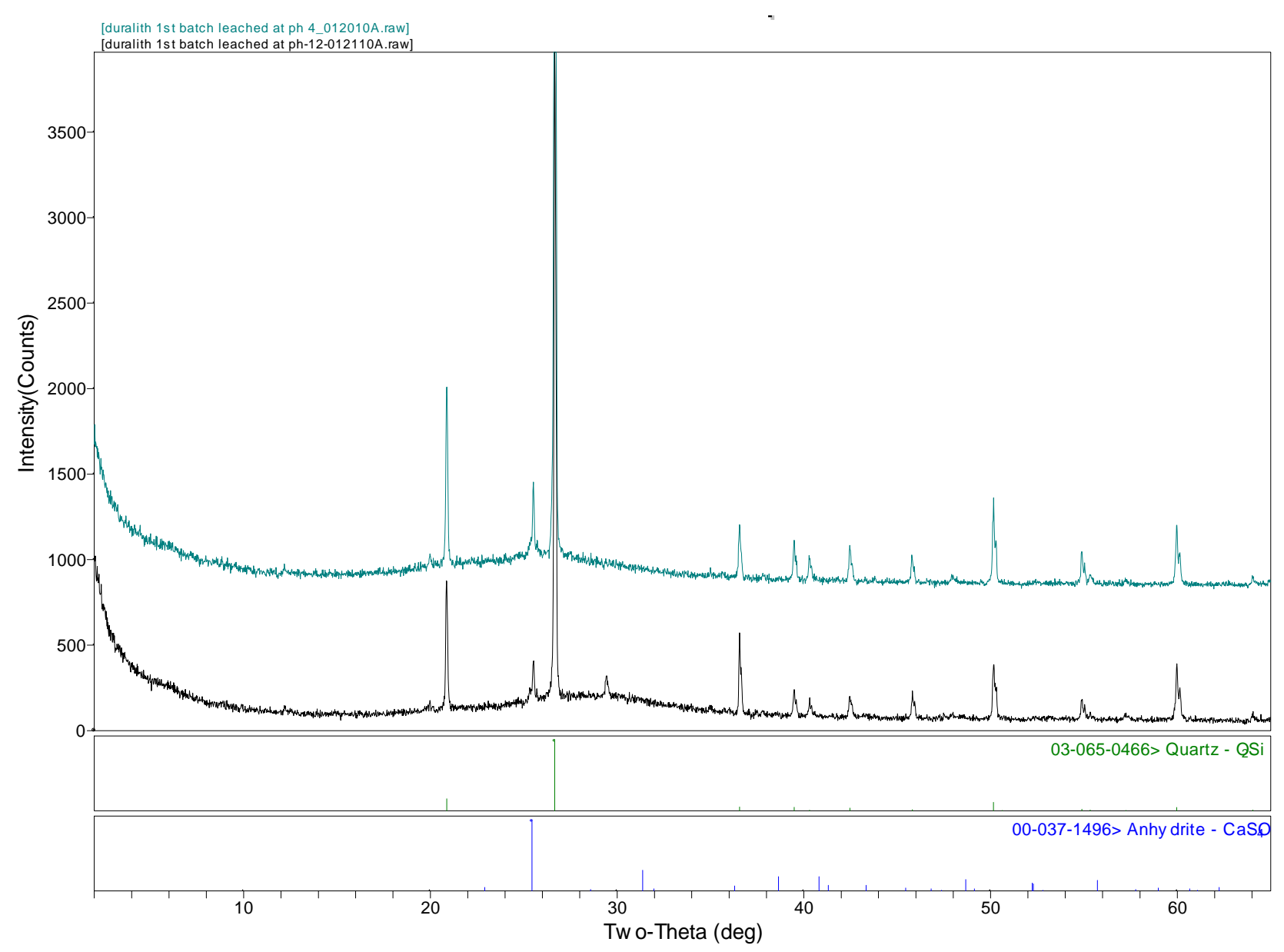

Figure C.2. EPA Method $1313 \mathrm{pH}\left(23^{\circ} \mathrm{C}\right)=4.0$ and 12.0 for Geopolymer Batch \#1 
Appendix D

Cast Stone Scanning Electron Microscopy Images 


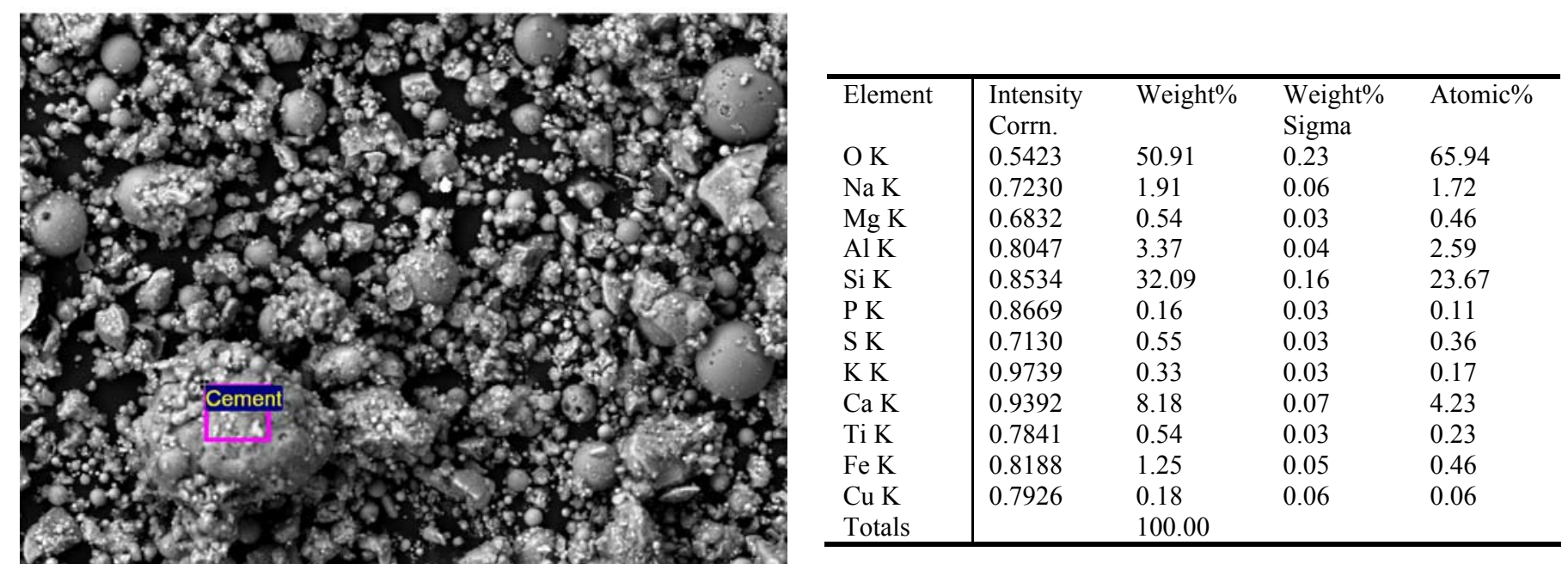

$200 \mu \mathrm{m}$

Electron Image 1

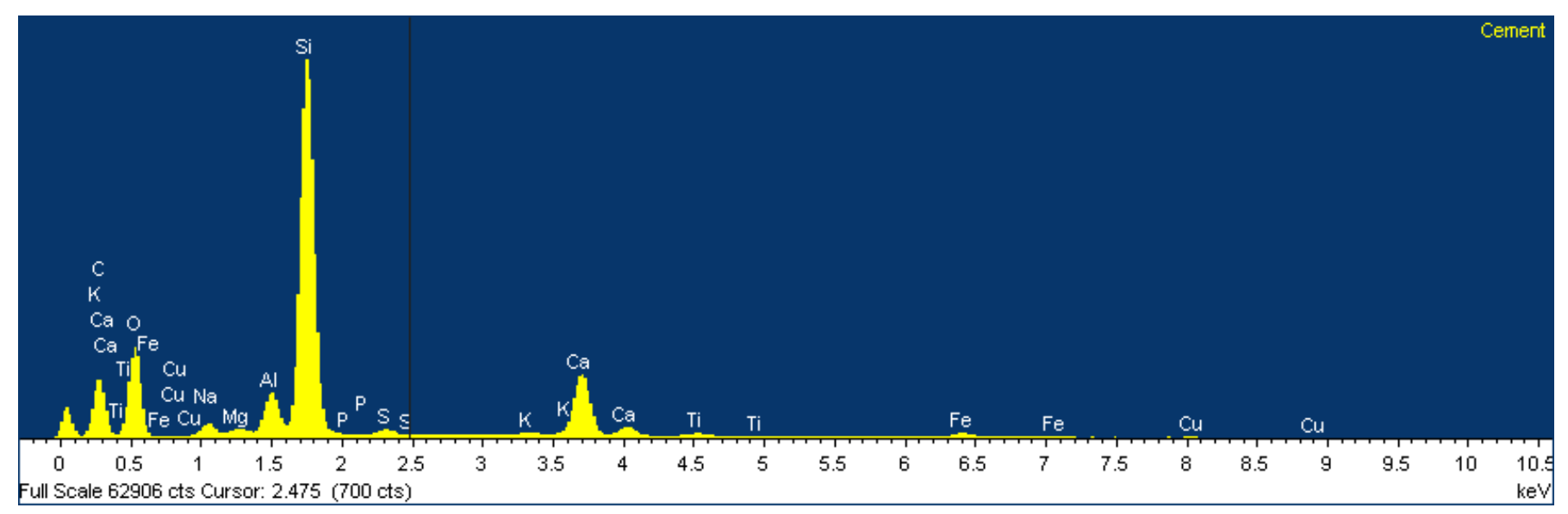

Figure D.1. 28-Day Cured Cast Stone 

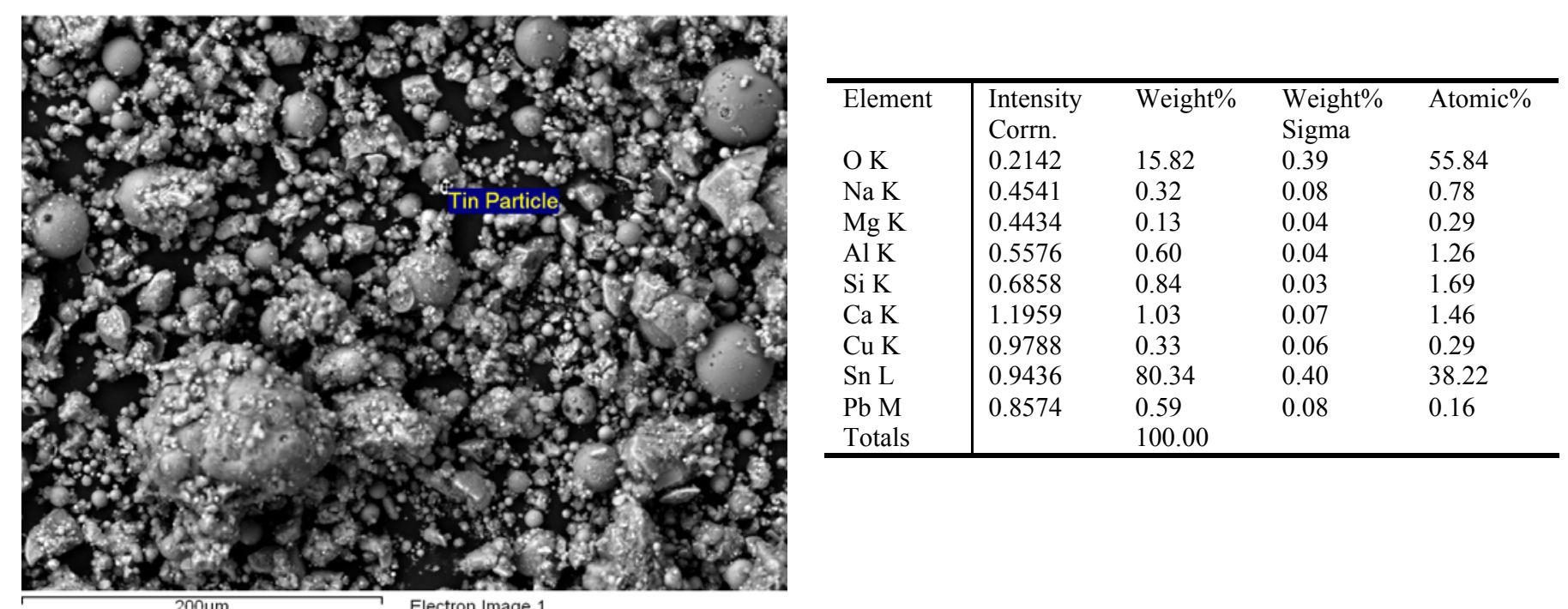

Electron Image 1

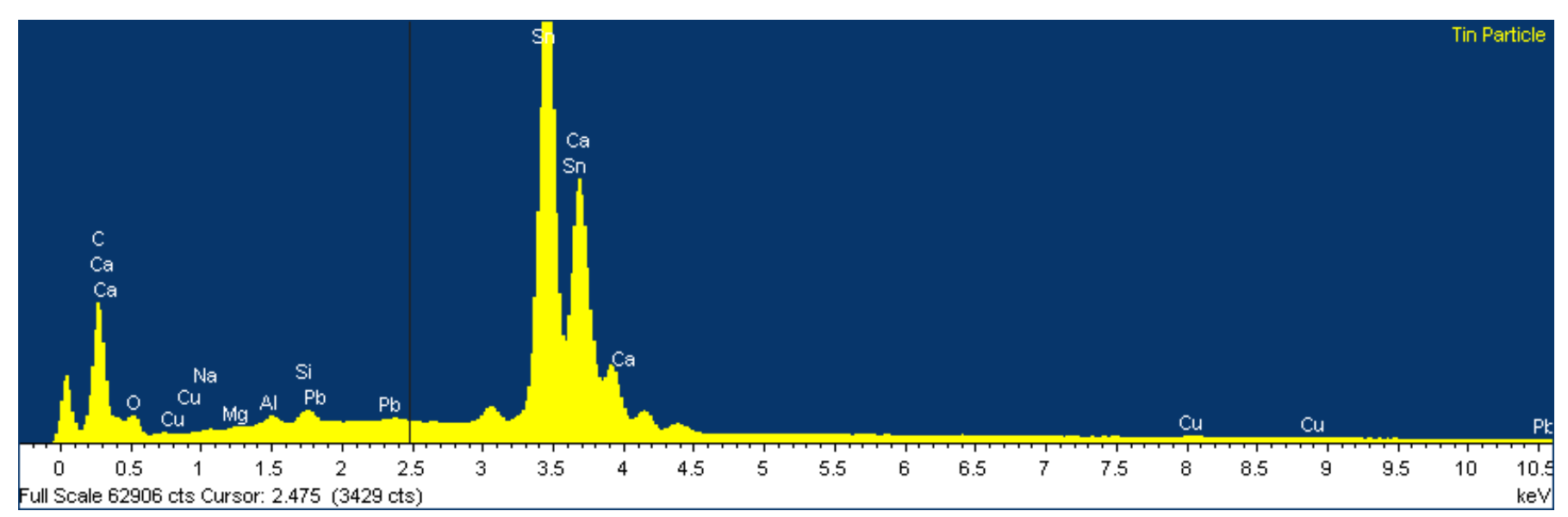

Figure D.2. 28-Day Cured Cast Stone 


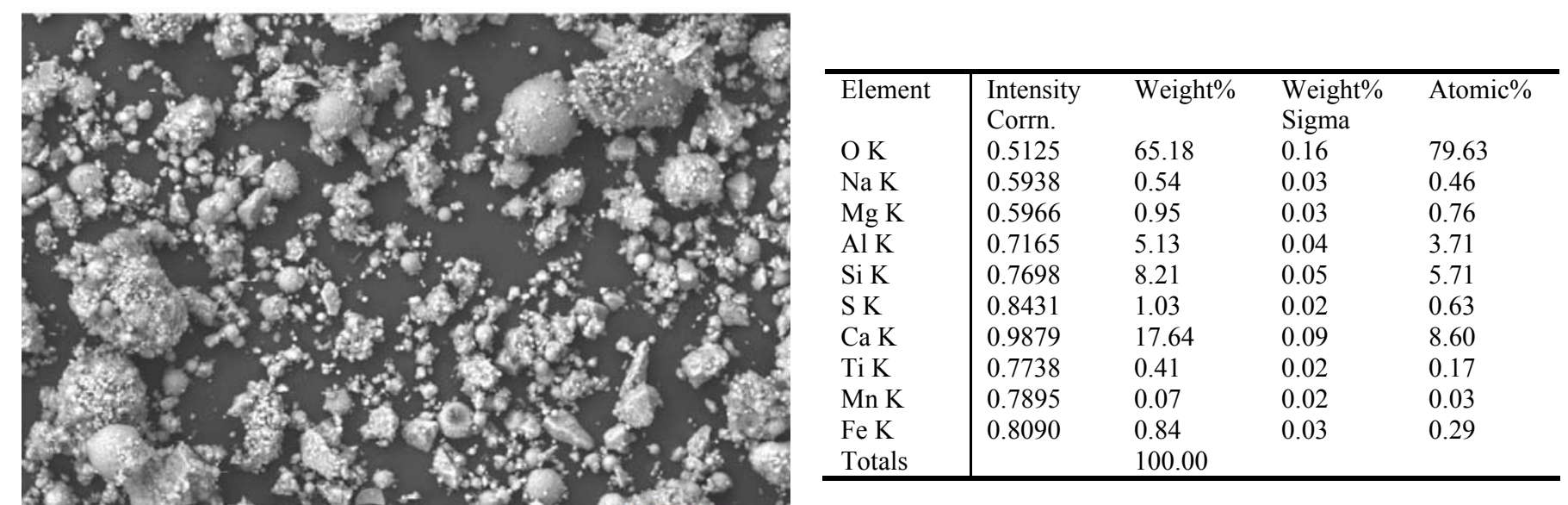

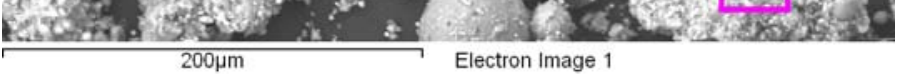

Electron Image 1

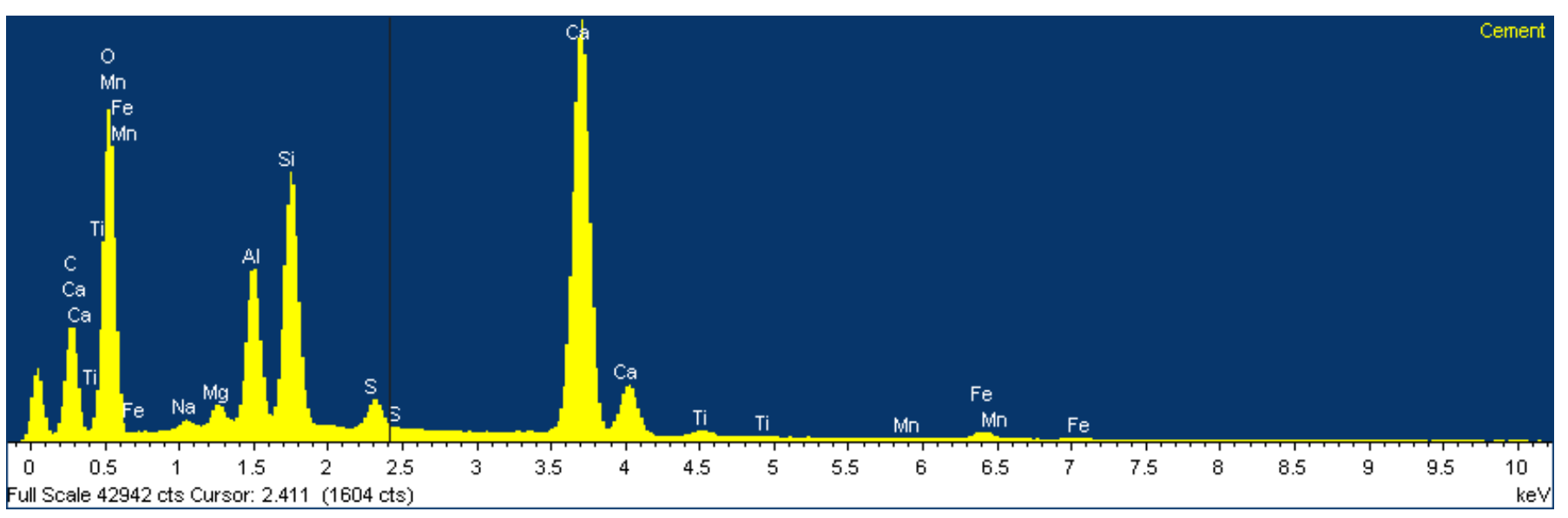

Figure D.3. Reacted Cast Stone using EPA Method 1313, $\mathrm{pH}\left(23^{\circ} \mathrm{C}\right)=12$ 


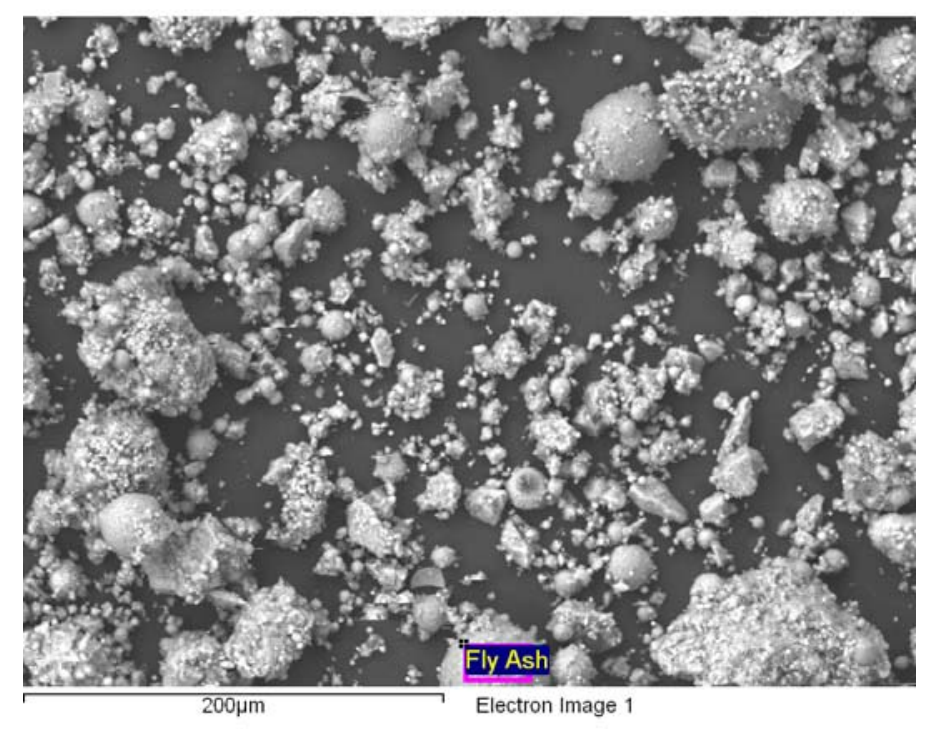

\begin{tabular}{l|llll}
\hline Element & $\begin{array}{l}\text { Intensity } \\
\text { Corrn. }\end{array}$ & Weight\% & $\begin{array}{l}\text { Weight\% } \\
\text { Sigma }\end{array}$ & Atomic\% \\
O K & 0.6788 & 58.37 & 0.14 & 71.84 \\
$\mathrm{Na} \mathrm{K}$ & 0.7088 & 3.45 & 0.05 & 2.96 \\
$\mathrm{Mg} \mathrm{K}$ & 0.6534 & 0.22 & 0.02 & 0.17 \\
$\mathrm{Al} \mathrm{K}$ & 0.7789 & 7.80 & 0.05 & 5.69 \\
$\mathrm{Si} \mathrm{K}$ & 0.7818 & 22.84 & 0.09 & 16.01 \\
$\mathrm{~K} \mathrm{~K}$ & 0.9781 & 2.41 & 0.03 & 1.21 \\
$\mathrm{Ca} \mathrm{K}$ & 0.9333 & 3.53 & 0.03 & 1.74 \\
Ti K & 0.7929 & 0.19 & 0.02 & 0.08 \\
Fe K & 0.8192 & 0.35 & 0.02 & 0.12 \\
Cu K & 0.7907 & 0.09 & 0.03 & 0.03 \\
Mo L & 0.6484 & 0.75 & 0.05 & 0.15 \\
Totals & & 100.00 & & \\
\hline
\end{tabular}

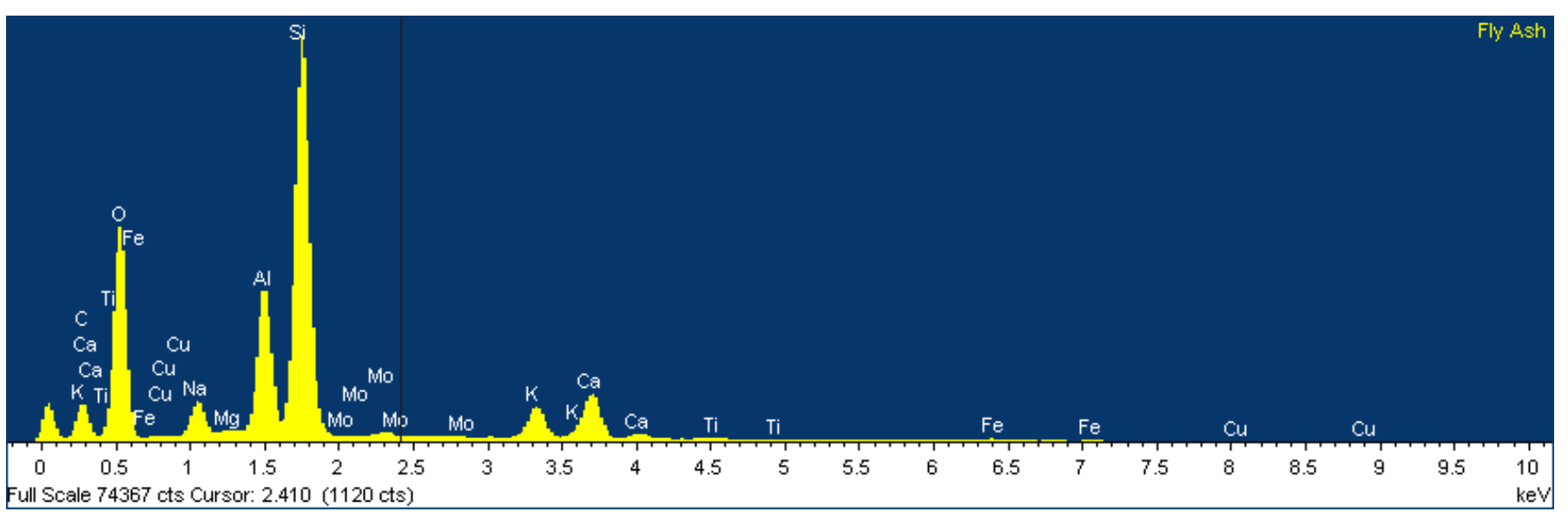

Figure D.4. Reacted Cast Stone using EPA Method 1313, $\mathrm{pH}\left(23^{\circ} \mathrm{C}\right)=12$ 


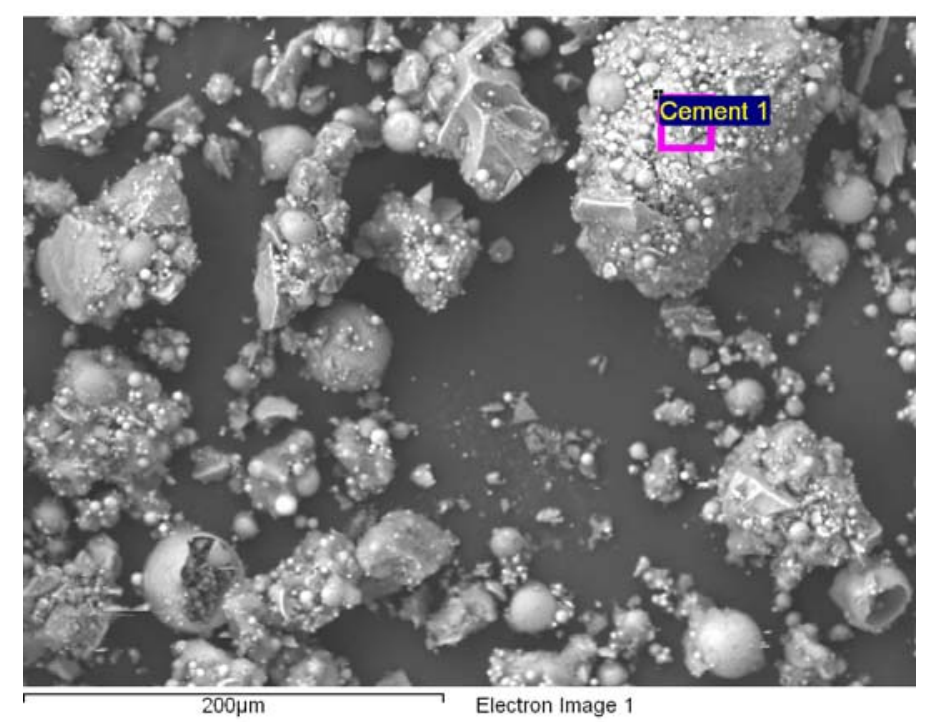

\begin{tabular}{l|llll}
\hline Element & $\begin{array}{l}\text { Intensity } \\
\text { Corrn. }\end{array}$ & Weight $\%$ & $\begin{array}{l}\text { Weight\% } \\
\text { Sigma }\end{array}$ & Atomic\% \\
O K & 0.6238 & 60.14 & 0.18 & 74.50 \\
Na K & 0.6427 & 1.07 & 0.05 & 0.93 \\
Mg K & 0.6304 & 0.85 & 0.03 & 0.69 \\
Al K & 0.7486 & 9.51 & 0.06 & 6.99 \\
Si K & 0.7447 & 15.12 & 0.08 & 10.67 \\
P K & 0.9600 & 0.29 & 0.02 & 0.19 \\
S K & 0.7720 & 0.19 & 0.02 & 0.12 \\
K K & 1.0141 & 0.20 & 0.02 & 0.10 \\
Ca K & 0.9659 & 9.42 & 0.06 & 4.66 \\
Ti K & 0.7920 & 0.49 & 0.02 & 0.20 \\
Mn K & 0.8001 & 0.11 & 0.02 & 0.04 \\
Fe K & 0.8185 & 2.45 & 0.04 & 0.87 \\
Cu K & 0.7888 & 0.14 & 0.04 & 0.04 \\
Totals & & 100.00 & & \\
\hline
\end{tabular}

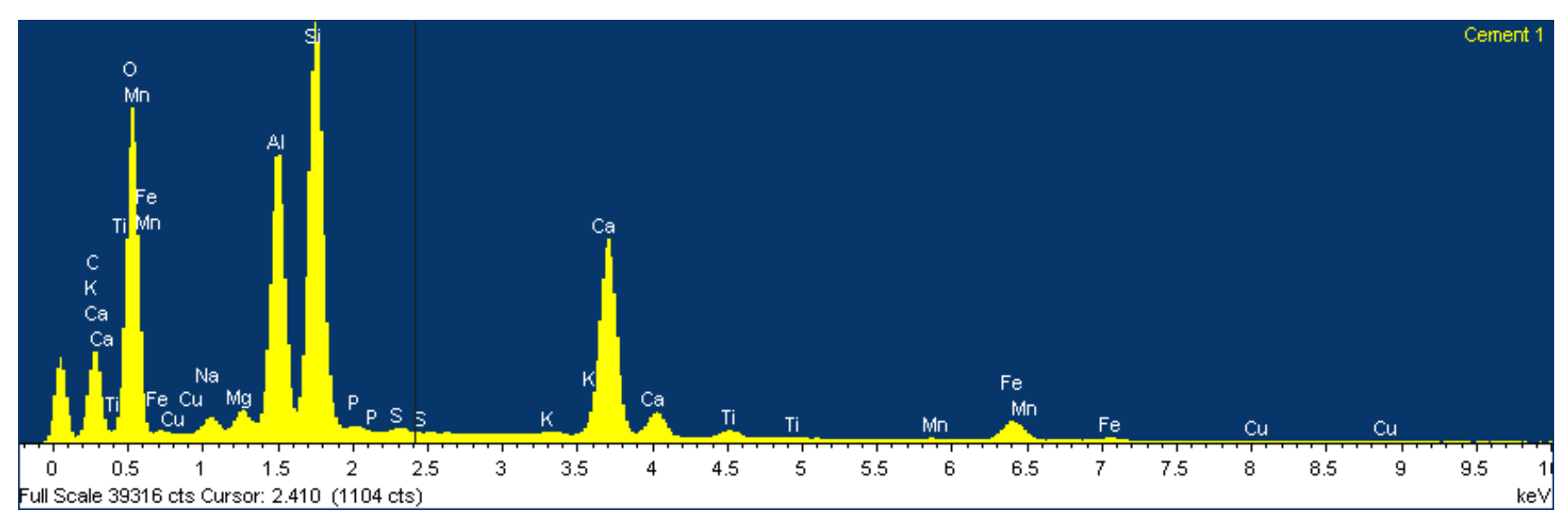

Figure D.5. Reacted Cast Stone using EPA Method 1313, $\mathrm{pH}\left(23^{\circ} \mathrm{C}\right)=4$ 

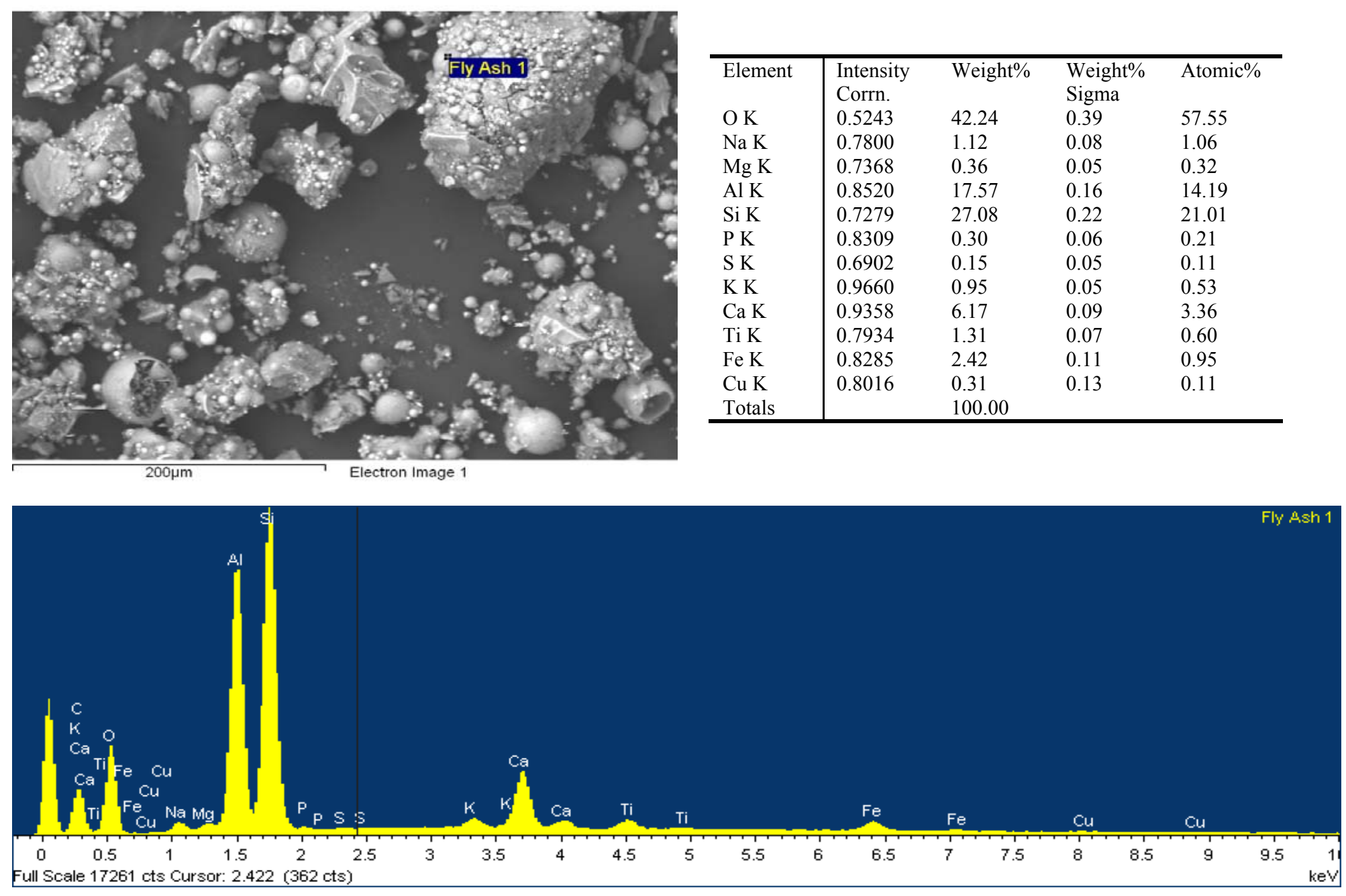

Figure D.6. Reacted Cast Stone using EPA Method 1313, $\mathrm{pH}\left(23^{\circ} \mathrm{C}\right)=4$ 


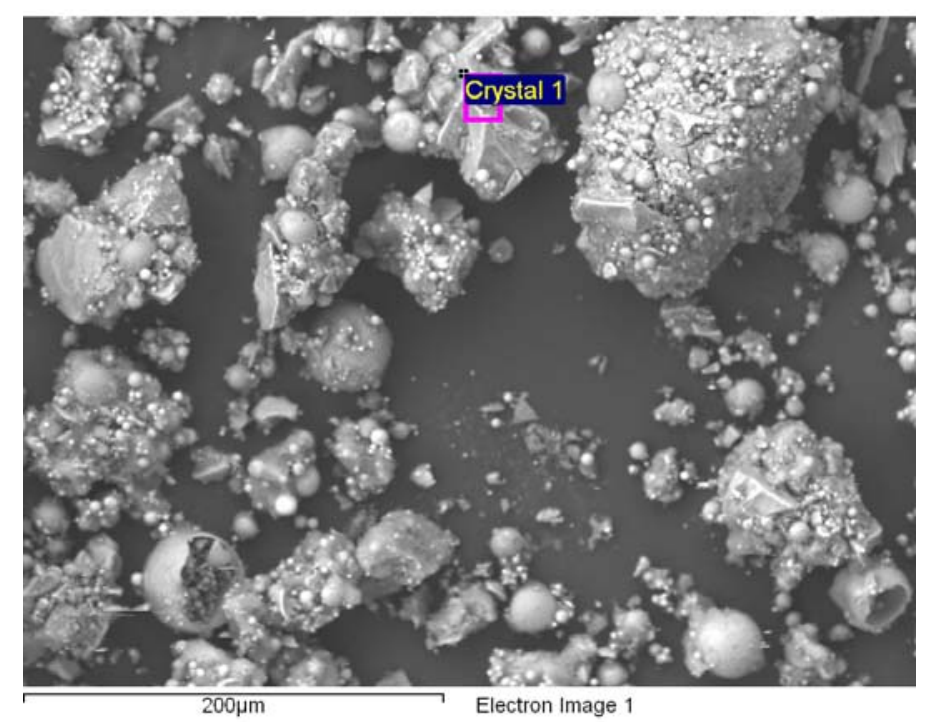

\begin{tabular}{l|llll}
\hline Element & $\begin{array}{l}\text { Intensity } \\
\text { Corrn. }\end{array}$ & Weight\% & $\begin{array}{l}\text { Weight } \% \\
\text { Sigma }\end{array}$ & Atomic\% \\
O K & 0.5981 & 63.96 & 0.14 & 77.54 \\
$\mathrm{Na} \mathrm{K}$ & 0.6323 & 0.49 & 0.04 & 0.42 \\
$\mathrm{Mg} \mathrm{K}$ & 0.6288 & 1.05 & 0.03 & 0.84 \\
$\mathrm{Al} \mathrm{K}$ & 0.7446 & 7.44 & 0.04 & 5.35 \\
$\mathrm{Si} \mathrm{K}$ & 0.7635 & 13.57 & 0.06 & 9.37 \\
$\mathrm{P} \mathrm{K}$ & 0.9938 & 0.16 & 0.02 & 0.10 \\
$\mathrm{~S} \mathrm{~K}$ & 0.7936 & 0.53 & 0.02 & 0.32 \\
$\mathrm{~K} \mathrm{~K}$ & 1.0249 & 0.18 & 0.01 & 0.09 \\
$\mathrm{Ca} \mathrm{K}$ & 0.9689 & 11.48 & 0.06 & 5.56 \\
$\mathrm{Ti} \mathrm{K}$ & 0.7836 & 0.45 & 0.02 & 0.18 \\
$\mathrm{Mn} \mathrm{K}$ & 0.7942 & 0.11 & 0.02 & 0.04 \\
Fe K & 0.8127 & 0.45 & 0.02 & 0.16 \\
Cu K & 0.7856 & 0.12 & 0.03 & 0.04 \\
Totals & & 100.00 & & \\
\hline \multicolumn{5}{|}{}
\end{tabular}

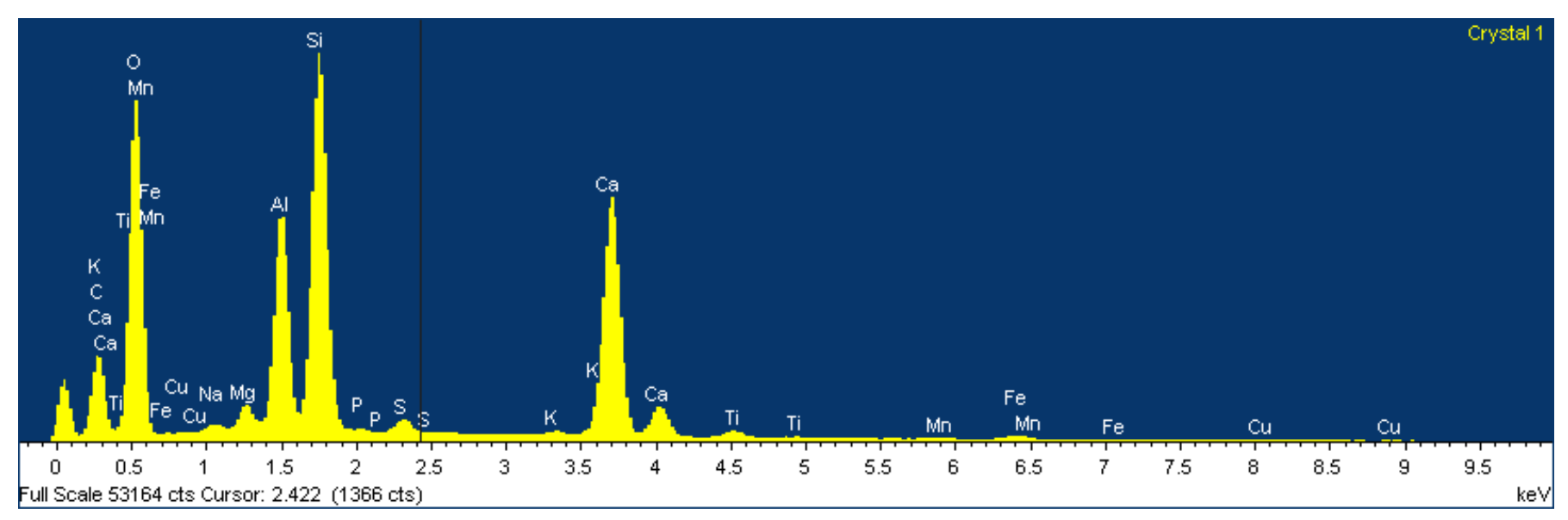

Figure D.7. Reacted Cast Stone using EPA Method 1313, $\mathrm{pH}\left(23^{\circ} \mathrm{C}\right)=4$ 


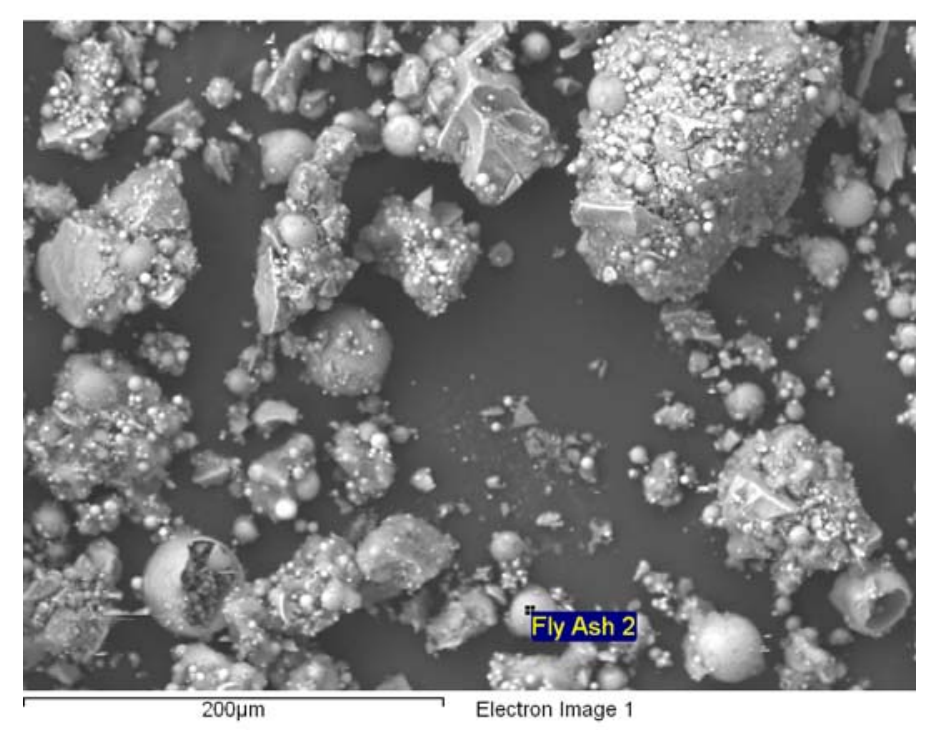

\begin{tabular}{l|llll}
\hline Element & $\begin{array}{l}\text { Intensity } \\
\text { Corrn. }\end{array}$ & Weight $\%$ & $\begin{array}{l}\text { Weight } \% \\
\text { Sigma }\end{array}$ & Atomic\% \\
O K & 0.7302 & 59.09 & 0.13 & 72.26 \\
$\mathrm{Na} \mathrm{K}$ & 0.6994 & 2.34 & 0.04 & 1.99 \\
$\mathrm{Mg} \mathrm{K}$ & 0.6599 & 0.67 & 0.03 & 0.54 \\
$\mathrm{Al} \mathrm{K}$ & 0.7787 & 7.22 & 0.04 & 5.24 \\
$\mathrm{Si} \mathrm{K}$ & 0.7871 & 24.90 & 0.09 & 17.35 \\
$\mathrm{P} \mathrm{K}$ & 0.8871 & 0.13 & 0.02 & 0.08 \\
$\mathrm{~S} \mathrm{~K}$ & 0.7251 & 0.10 & 0.02 & 0.06 \\
$\mathrm{~K} \mathrm{~K}$ & 0.9748 & 0.29 & 0.02 & 0.15 \\
$\mathrm{Ca} \mathrm{K}$ & 0.9424 & 3.39 & 0.03 & 1.65 \\
Ti K & 0.7980 & 0.46 & 0.02 & 0.19 \\
Fe K & 0.8190 & 1.41 & 0.03 & 0.49 \\
Totals & & 100.00 & & \\
\hline
\end{tabular}

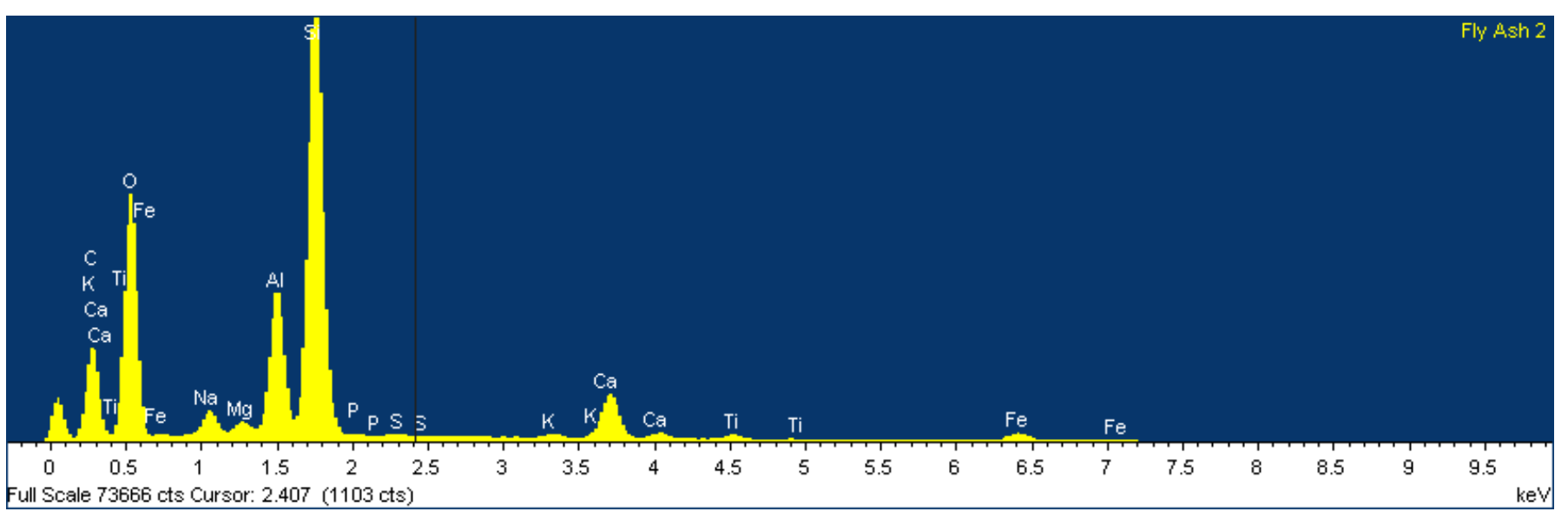

Figure D.8. Reacted Cast Stone using EPA Method $1313, \mathrm{pH}\left(23^{\circ} \mathrm{C}\right)=4$ 


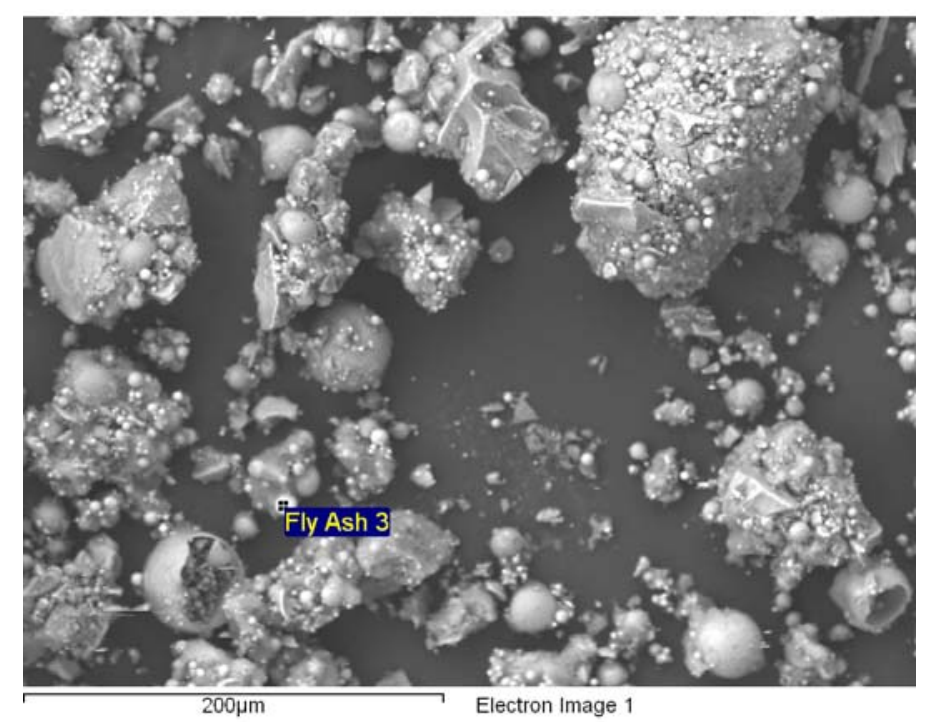

\begin{tabular}{l|llll}
\hline Element & $\begin{array}{l}\text { Intensity } \\
\text { Corrn. }\end{array}$ & Weight $\%$ & $\begin{array}{l}\text { Weight } \% \\
\text { Sigma }\end{array}$ & Atomic\% \\
$\mathrm{O} \mathrm{K}$ & 0.7643 & 59.88 & 0.16 & 75.26 \\
$\mathrm{Na} \mathrm{K}$ & 0.5956 & 0.79 & 0.06 & 0.69 \\
$\mathrm{Mg} \mathrm{K}$ & 0.5942 & 0.43 & 0.03 & 0.35 \\
$\mathrm{Al} \mathrm{K}$ & 0.7201 & 8.07 & 0.05 & 6.02 \\
$\mathrm{Si} \mathrm{K}$ & 0.7401 & 16.07 & 0.08 & 11.51 \\
$\mathrm{P} \mathrm{K}$ & 0.9472 & 0.27 & 0.03 & 0.18 \\
$\mathrm{~S} \mathrm{~K}$ & 0.7648 & 0.13 & 0.02 & 0.08 \\
$\mathrm{~K} \mathrm{~K}$ & 1.0088 & 0.14 & 0.02 & 0.07 \\
$\mathrm{Ca} \mathrm{K}$ & 0.9708 & 4.85 & 0.04 & 2.43 \\
$\mathrm{Ti} \mathrm{K}$ & 0.8158 & 0.75 & 0.03 & 0.32 \\
$\mathrm{Fe} \mathrm{K}$ & 0.8287 & 8.46 & 0.07 & 3.05 \\
$\mathrm{Cu} \mathrm{K}$ & 0.7899 & 0.15 & 0.04 & 0.05 \\
Totals & & 100.00 & & \\
\hline
\end{tabular}

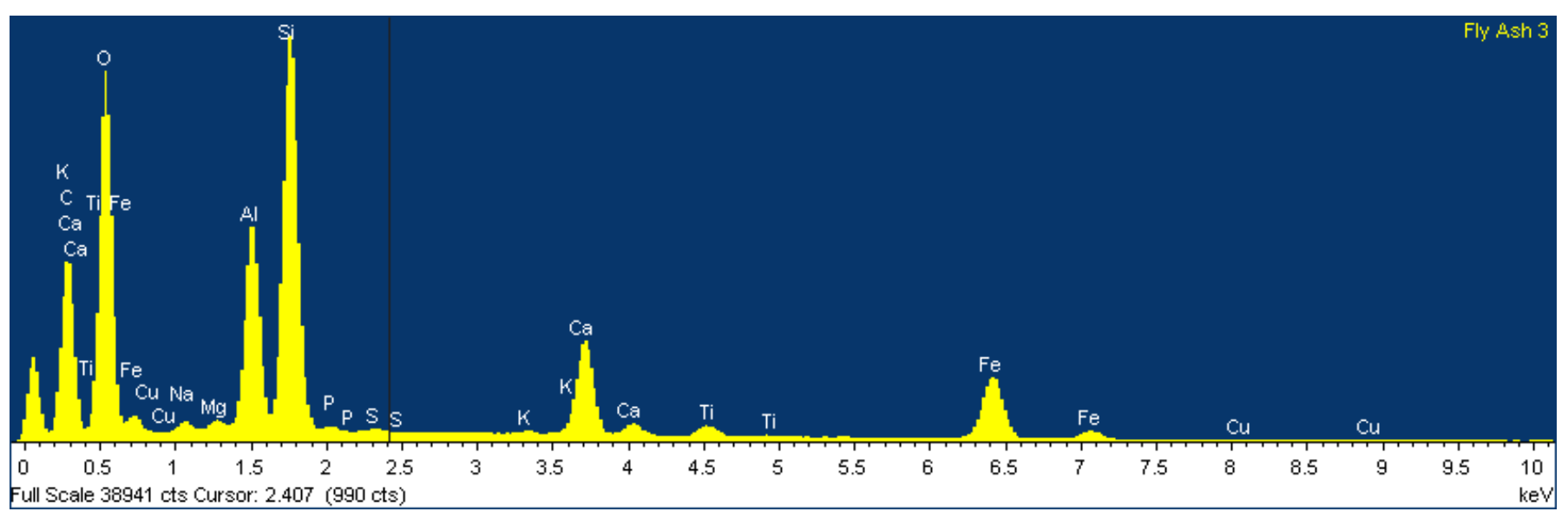

Figure D.9. Reacted Cast Stone using EPA Method 1313, $\mathrm{pH}\left(23^{\circ} \mathrm{C}\right)=4$ 


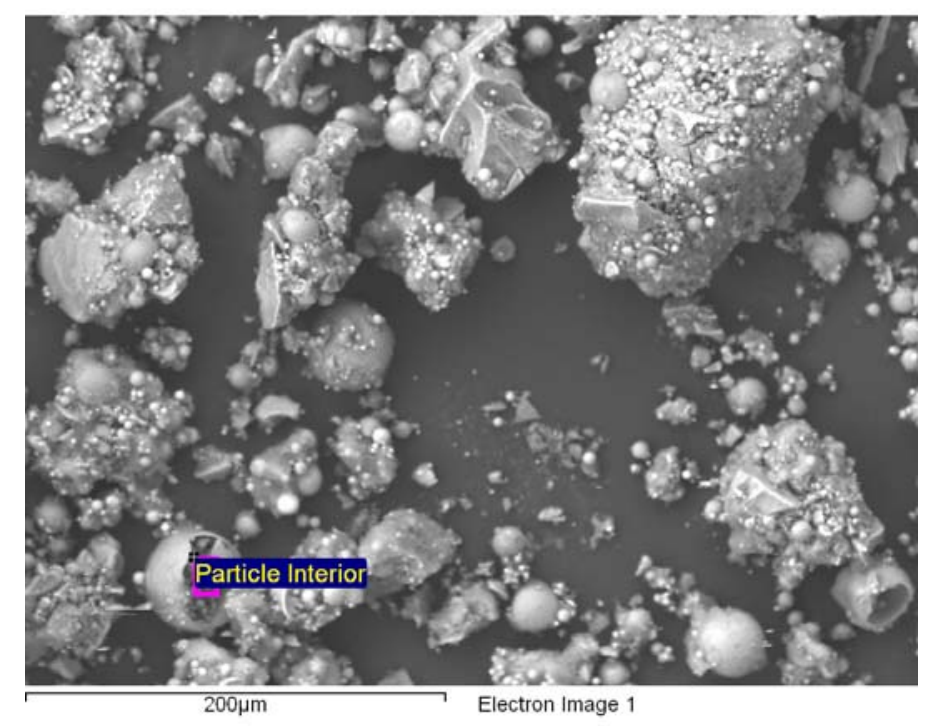

\begin{tabular}{l|llll}
\hline Element & $\begin{array}{l}\text { Intensity } \\
\text { Corrn. }\end{array}$ & Weight\% & $\begin{array}{l}\text { Weight } \% \\
\text { Sigma }\end{array}$ & Atomic\% \\
O K & 0.5970 & 52.11 & 0.21 & 67.82 \\
$\mathrm{Na} \mathrm{K}$ & 0.6667 & 2.35 & 0.07 & 2.13 \\
$\mathrm{Mg} \mathrm{K}$ & 0.6347 & 1.03 & 0.04 & 0.88 \\
$\mathrm{Al} \mathrm{K}$ & 0.7509 & 10.39 & 0.07 & 8.02 \\
$\mathrm{Si} \mathrm{K}$ & 0.7384 & 19.52 & 0.11 & 14.48 \\
$\mathrm{P} \mathrm{K}$ & 0.9103 & 0.31 & 0.03 & 0.21 \\
$\mathrm{~K} \mathrm{~K}$ & 0.9997 & 0.43 & 0.03 & 0.23 \\
$\mathrm{Ca} \mathrm{K}$ & 0.9630 & 6.15 & 0.05 & 3.20 \\
Ti K & 0.8055 & 2.69 & 0.04 & 1.17 \\
Fe K & 0.8266 & 4.83 & 0.07 & 1.80 \\
Cu K & 0.7954 & 0.18 & 0.06 & 0.06 \\
Totals & & 100.00 & & \\
\hline
\end{tabular}

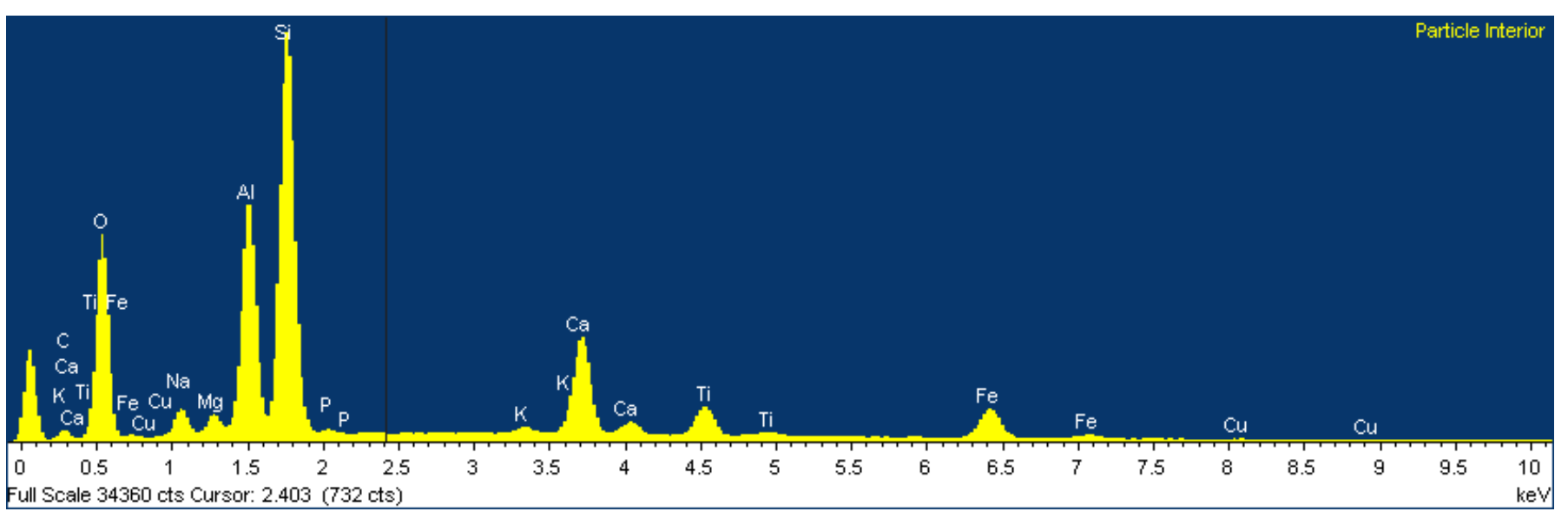

Figure D.10. Reacted Cast Stone using EPA Method $1313, \mathrm{pH}\left(23^{\circ} \mathrm{C}\right)=4$ 


\section{Appendix E}

Geopolymer Scanning Electron Microscopy Images 


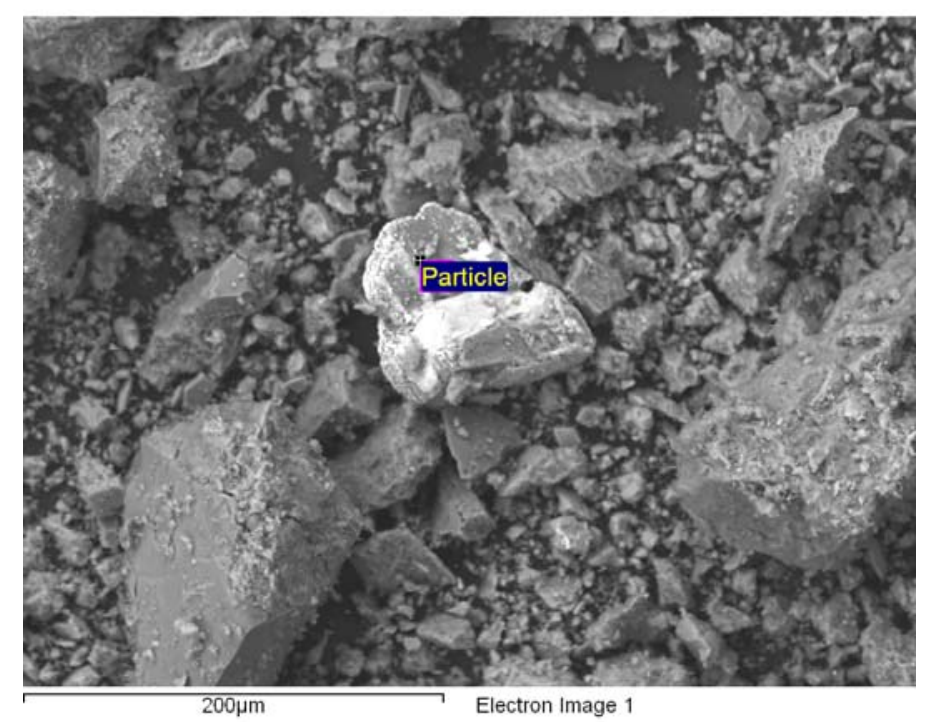

\begin{tabular}{l|llll}
\hline Element & $\begin{array}{l}\text { Intensity } \\
\text { Corrn. }\end{array}$ & Weight $\%$ & $\begin{array}{l}\text { Weight } \% \\
\text { Sigma }\end{array}$ & Atomic\% \\
$\mathrm{O} \mathrm{K}$ & 0.7349 & 57.66 & 0.15 & 72.44 \\
$\mathrm{Na} \mathrm{K}$ & 0.6920 & 3.32 & 0.08 & 2.90 \\
$\mathrm{Mg} \mathrm{K}$ & 0.6401 & 0.45 & 0.03 & 0.37 \\
$\mathrm{Al} \mathrm{K}$ & 0.7620 & 9.83 & 0.05 & 7.32 \\
$\mathrm{Si} \mathrm{K}$ & 0.7521 & 19.11 & 0.08 & 13.67 \\
$\mathrm{~K} \mathrm{~K}$ & 0.9736 & 0.59 & 0.02 & 0.30 \\
$\mathrm{Ca} \mathrm{K}$ & 0.9403 & 3.75 & 0.03 & 1.88 \\
$\mathrm{Ti} \mathrm{K}$ & 0.7994 & 0.08 & 0.02 & 0.03 \\
$\mathrm{Fe} \mathrm{K}$ & 0.8276 & 1.88 & 0.04 & 0.68 \\
$\mathrm{Cu} \mathrm{K}$ & 0.7979 & 0.24 & 0.04 & 0.08 \\
$\mathrm{Zn} \mathrm{K}$ & 0.7968 & 0.10 & 0.04 & 0.03 \\
$\mathrm{~Pb} \mathrm{M}$ & 0.7098 & 3.00 & 0.07 & 0.29 \\
& & & & \\
Totals & \multicolumn{5}{|c}{100.00} & & \\
\hline
\end{tabular}

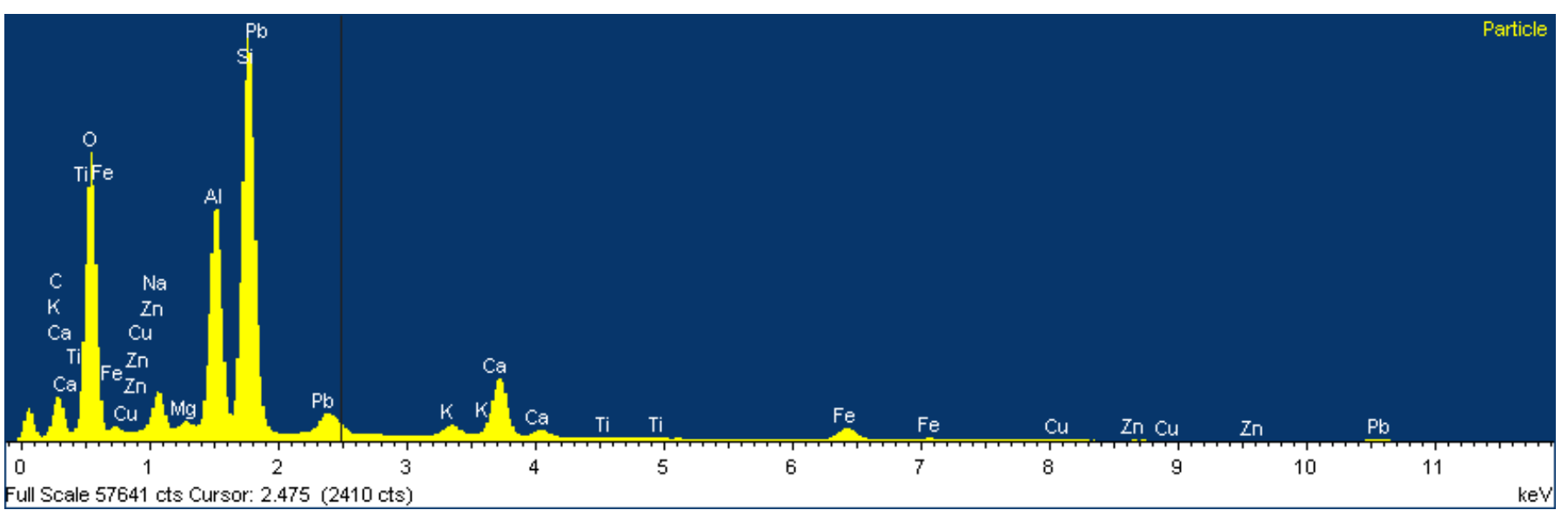

Figure E.1. 30-Day Cured Geopolymer Batch \#1 


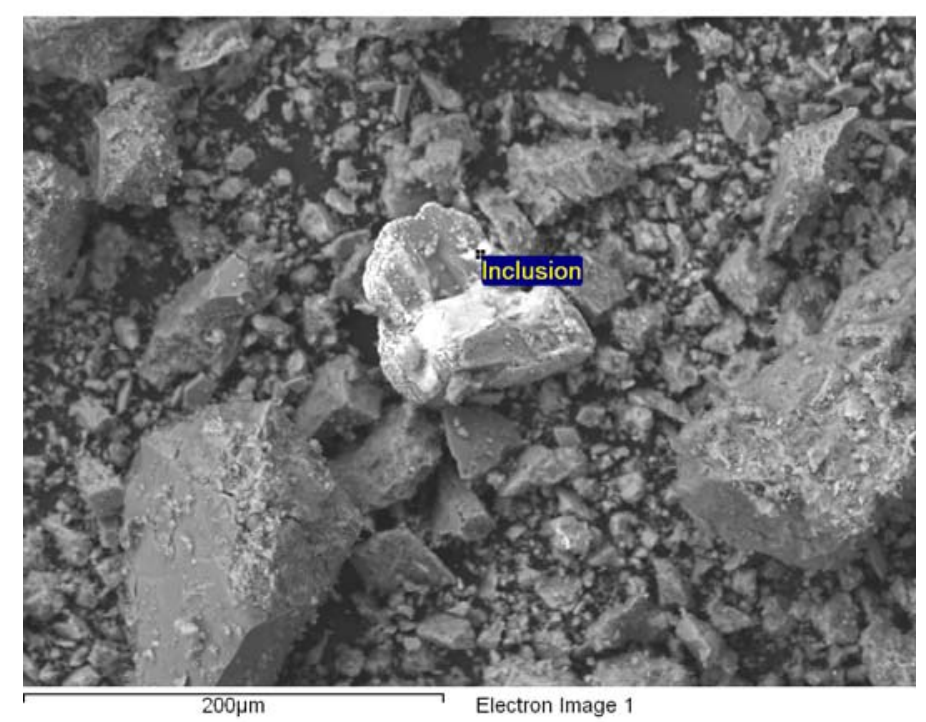

\begin{tabular}{l|llll}
\hline Element & $\begin{array}{l}\text { Intensity } \\
\text { Corrn. }\end{array}$ & Weight $\%$ & $\begin{array}{l}\text { Weight } \% \\
\text { Sigma }\end{array}$ & Atomic\% \\
$\mathrm{O} \mathrm{K}$ & 0.6479 & 47.56 & 0.23 & 70.15 \\
$\mathrm{Na} \mathrm{K}$ & 0.6448 & 0.92 & 0.09 & 0.95 \\
$\mathrm{Mg} \mathrm{K}$ & 0.6206 & 0.97 & 0.04 & 0.95 \\
$\mathrm{Al} \mathrm{K}$ & 0.7374 & 6.65 & 0.06 & 5.82 \\
$\mathrm{Si} \mathrm{K}$ & 0.7805 & 17.84 & 0.10 & 14.99 \\
$\mathrm{~K} \mathrm{~K}$ & 0.9478 & 0.41 & 0.04 & 0.25 \\
$\mathrm{Ca} \mathrm{K}$ & 0.9281 & 3.03 & 0.04 & 1.79 \\
$\mathrm{Ti} \mathrm{K}$ & 0.8040 & 0.08 & 0.03 & 0.04 \\
$\mathrm{Fe} \mathrm{K}$ & 0.8582 & 6.90 & 0.07 & 2.91 \\
$\mathrm{Cu} \mathrm{K}$ & 0.8325 & 0.61 & 0.06 & 0.23 \\
$\mathrm{Zn} \mathrm{K}$ & 0.8354 & 0.36 & 0.06 & 0.13 \\
$\mathrm{Sn} \mathrm{L}$ & 0.7351 & 1.70 & 0.11 & 0.34 \\
$\mathrm{~Pb} \mathrm{M}$ & 0.7450 & 12.96 & 0.13 & 1.48 \\
Totals & & 100.00 & & \\
\hline
\end{tabular}

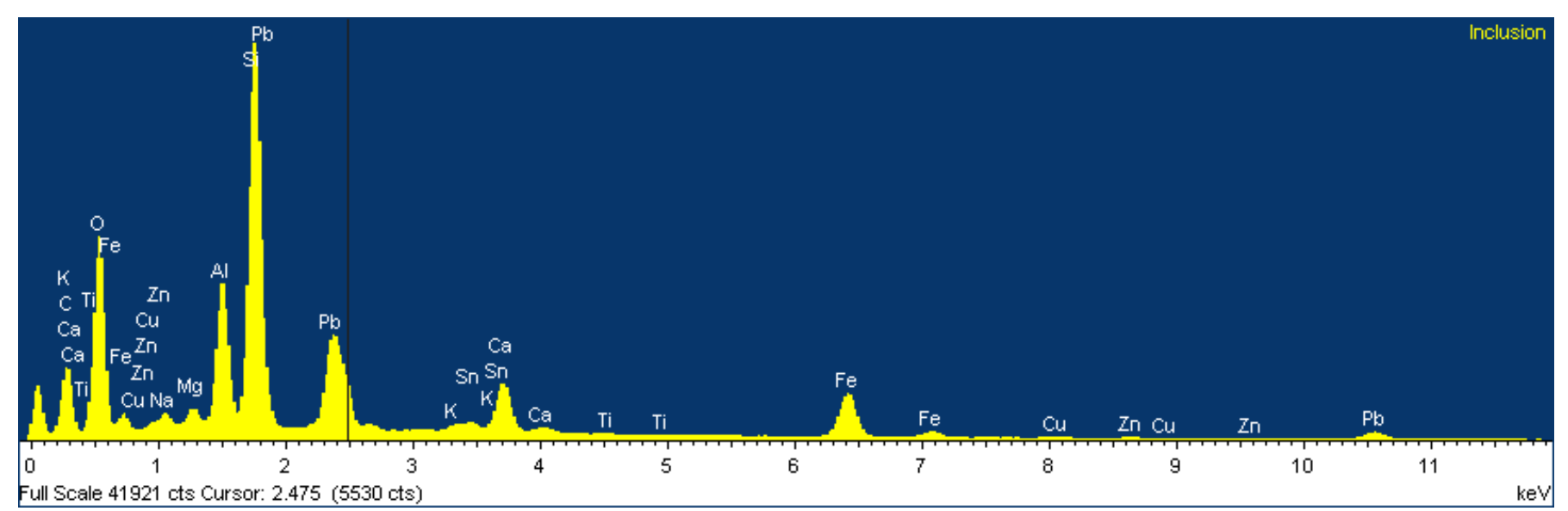

Figure E.2. 30-Day Cured Geopolymer Batch \#1 


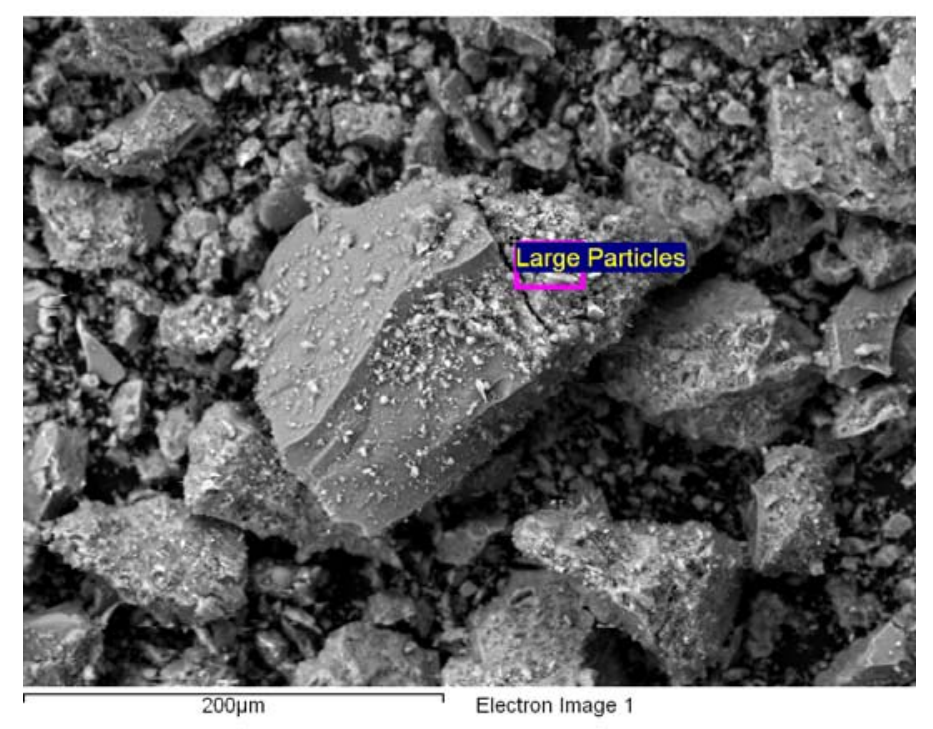

\begin{tabular}{l|llll}
\hline Element & $\begin{array}{l}\text { Intensity } \\
\text { Corrn. }\end{array}$ & Weight $\%$ & $\begin{array}{l}\text { Weight } \% \\
\text { Sigma }\end{array}$ & Atomic\% \\
O K & 0.5246 & 53.00 & 0.33 & 68.19 \\
$\mathrm{Na} \mathrm{K}$ & 0.7109 & 2.19 & 0.06 & 1.96 \\
$\mathrm{Mg} \mathrm{K}$ & 0.6710 & 0.82 & 0.04 & 0.70 \\
$\mathrm{Al} \mathrm{K}$ & 0.7875 & 8.94 & 0.08 & 6.82 \\
$\mathrm{Si} \mathrm{K}$ & 0.7783 & 19.92 & 0.15 & 14.60 \\
$\mathrm{~S} \mathrm{~K}$ & 0.7616 & 0.25 & 0.02 & 0.16 \\
$\mathrm{~K} \mathrm{~K}$ & 0.9995 & 10.16 & 0.09 & 5.35 \\
$\mathrm{Ca} \mathrm{K}$ & 0.9077 & 3.63 & 0.05 & 1.87 \\
$\mathrm{Ti} \mathrm{K}$ & 0.7816 & 0.41 & 0.03 & 0.18 \\
Fe K & 0.8192 & 0.23 & 0.04 & 0.08 \\
Cu K & 0.7949 & 0.11 & 0.05 & 0.04 \\
Ag L & 0.7656 & 0.33 & 0.06 & 0.06 \\
Totals & & 100.00 & & \\
\hline
\end{tabular}

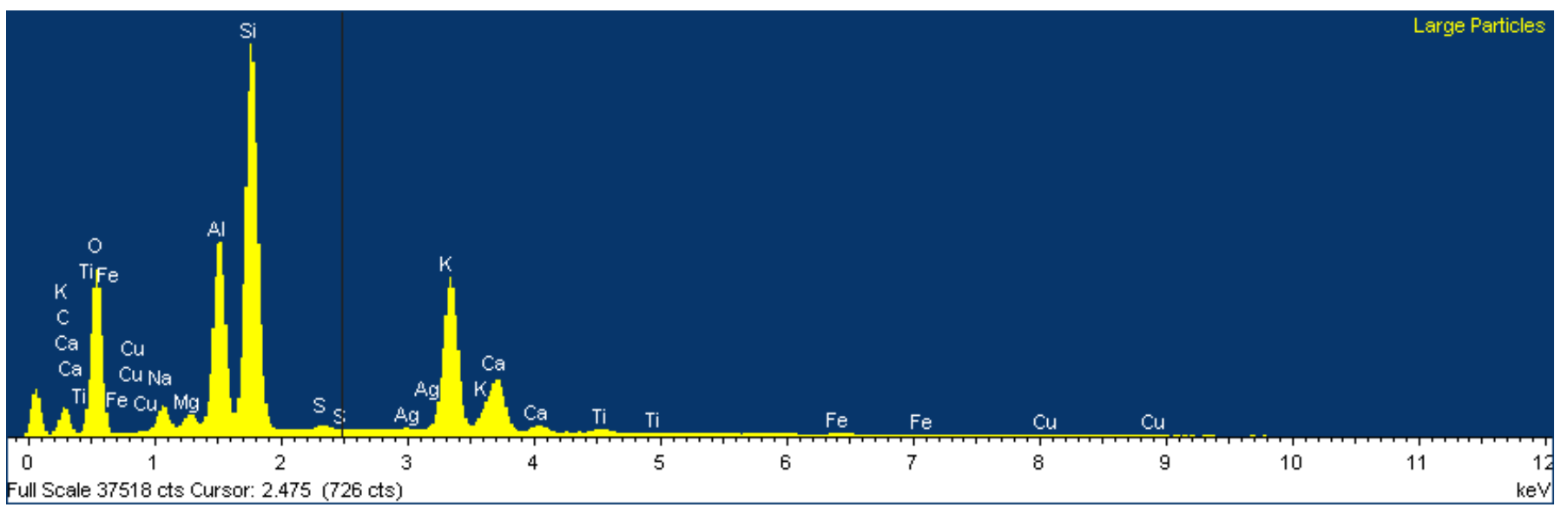

Figure E.3. 30-Day Cured Geopolymer Batch \#1 


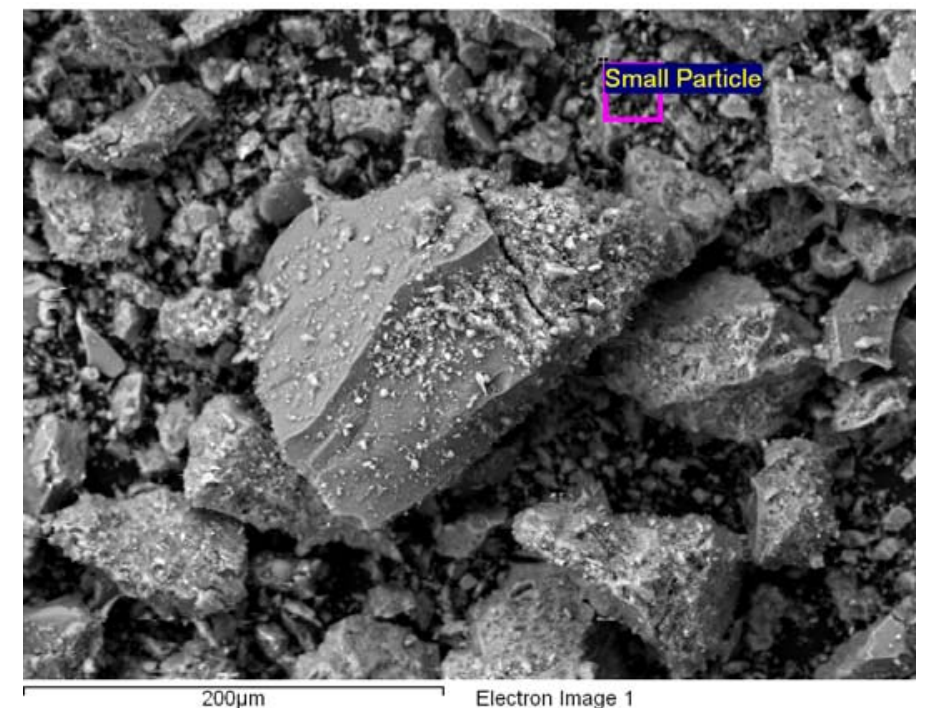

\begin{tabular}{|c|c|c|c|c|}
\hline Element & $\begin{array}{l}\text { Intensity } \\
\text { Corrn. }\end{array}$ & Weight $\%$ & $\begin{array}{l}\text { Weight\% } \\
\text { Sigma }\end{array}$ & Atomic\% \\
\hline O K & 0.6073 & 57.62 & 0.29 & 71.76 \\
\hline $\mathrm{Na} \mathrm{K}$ & 0.6957 & 2.83 & 0.07 & 2.46 \\
\hline $\operatorname{Mg~K}$ & 0.6515 & 0.66 & 0.04 & 0.54 \\
\hline Al K & 0.7711 & 8.44 & 0.08 & 6.23 \\
\hline Si K & 0.7712 & 18.64 & 0.14 & 13.22 \\
\hline S K & 0.7640 & 0.30 & 0.02 & 0.18 \\
\hline K K & 0.9968 & 7.99 & 0.07 & 4.07 \\
\hline $\mathrm{Ca} \mathrm{K}$ & 0.9158 & 2.44 & 0.04 & 1.21 \\
\hline Ti K & 0.7877 & 0.30 & 0.03 & 0.13 \\
\hline $\mathrm{Fe} \mathrm{K}$ & 0.8186 & 0.21 & 0.03 & 0.07 \\
\hline $\mathrm{Cu} \mathrm{K}$ & 0.7919 & 0.11 & 0.05 & 0.04 \\
\hline $\mathrm{Ag} \mathrm{L}$ & 0.7648 & 0.46 & 0.06 & 0.08 \\
\hline Totals & & 100.00 & & \\
\hline
\end{tabular}

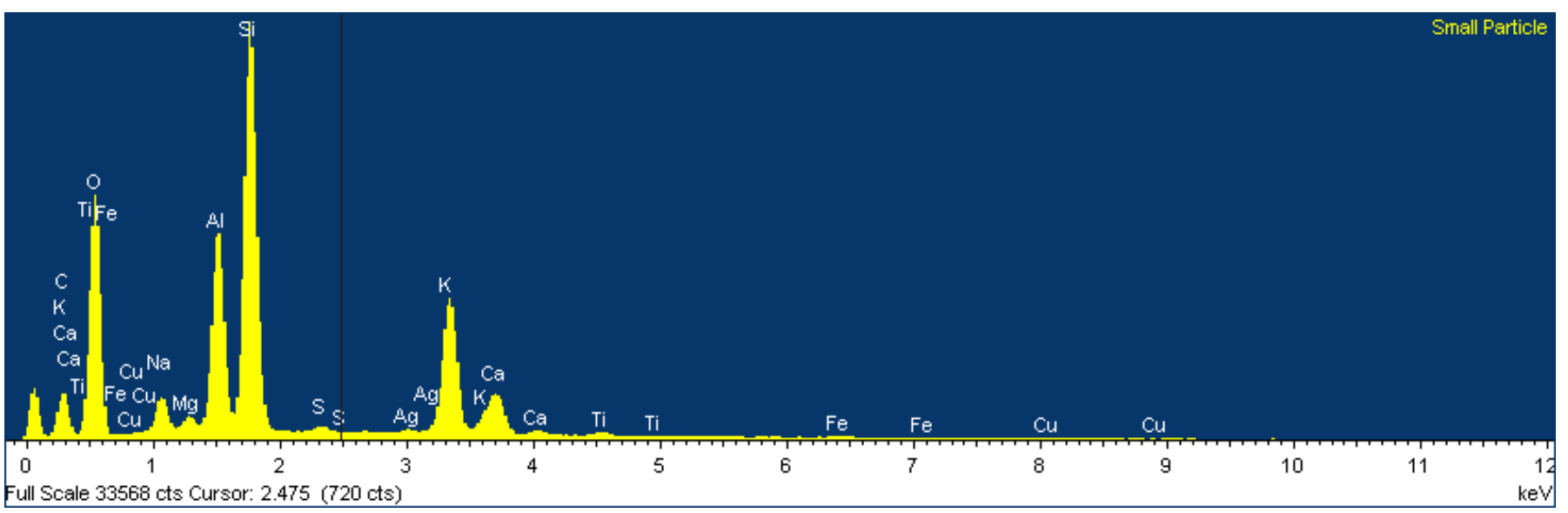

Figure E.4. 30-Day Cured Geopolymer Batch \#1 


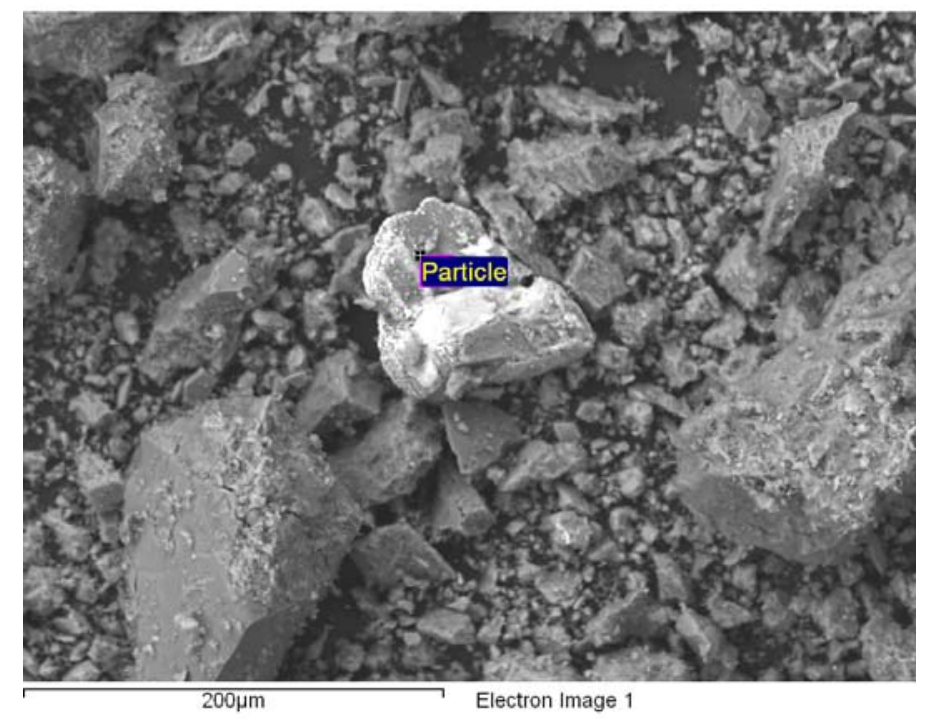

\begin{tabular}{l|llll}
\hline Element & $\begin{array}{l}\text { Intensity } \\
\text { Corrn. }\end{array}$ & Weight $\%$ & $\begin{array}{l}\text { Weight } \% \\
\text { Sigma }\end{array}$ & Atomic\% \\
$\mathrm{O} \mathrm{K}$ & 0.7349 & 57.66 & 0.15 & 72.44 \\
$\mathrm{Na} \mathrm{K}$ & 0.6920 & 3.32 & 0.08 & 2.90 \\
$\mathrm{Mg} \mathrm{K}$ & 0.6401 & 0.45 & 0.03 & 0.37 \\
$\mathrm{Al} \mathrm{K}$ & 0.7620 & 9.83 & 0.05 & 7.32 \\
$\mathrm{Si} \mathrm{K}$ & 0.7521 & 19.11 & 0.08 & 13.67 \\
$\mathrm{~K} \mathrm{~K}$ & 0.9736 & 0.59 & 0.02 & 0.30 \\
$\mathrm{Ca} \mathrm{K}$ & 0.9403 & 3.75 & 0.03 & 1.88 \\
$\mathrm{Ti} \mathrm{K}$ & 0.7994 & 0.08 & 0.02 & 0.03 \\
$\mathrm{Fe} \mathrm{K}$ & 0.8276 & 1.88 & 0.04 & 0.68 \\
$\mathrm{Cu} \mathrm{K}$ & 0.7979 & 0.24 & 0.04 & 0.08 \\
$\mathrm{Zn} \mathrm{K}$ & 0.7968 & 0.10 & 0.04 & 0.03 \\
$\mathrm{~Pb} \mathrm{M}$ & 0.7098 & 3.00 & 0.07 & 0.29 \\
Totals & & 100.00 & & \\
\hline
\end{tabular}

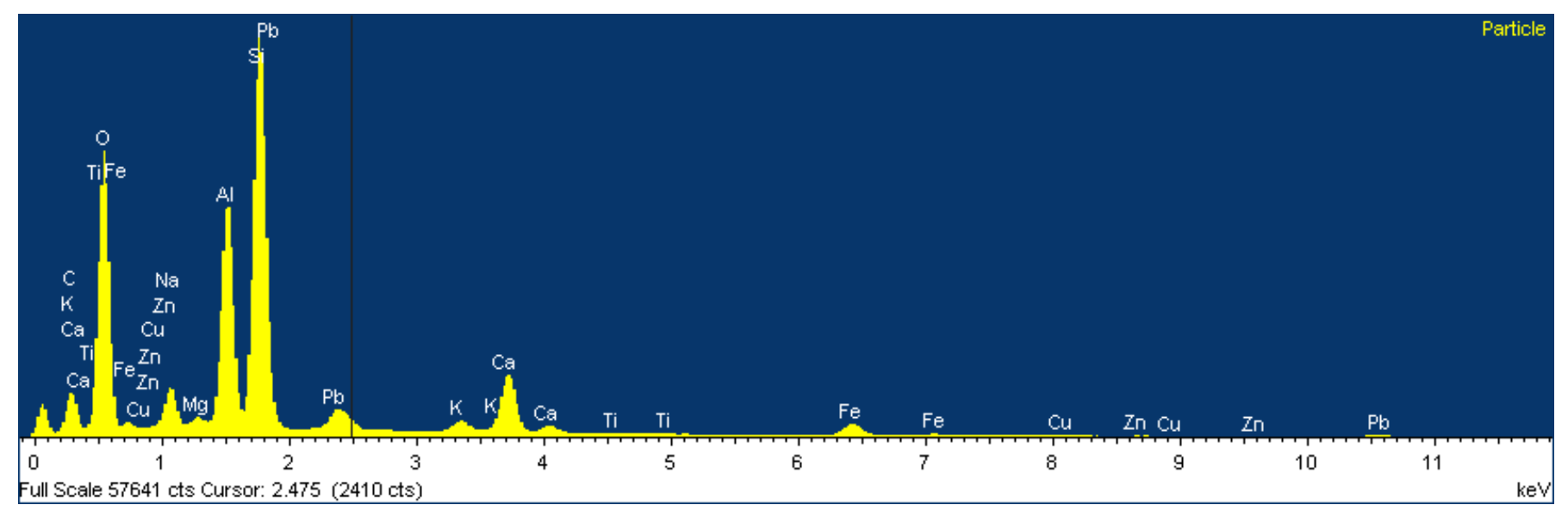

Figure E.5. 30-Day Cured Geopolymer Batch \#1 


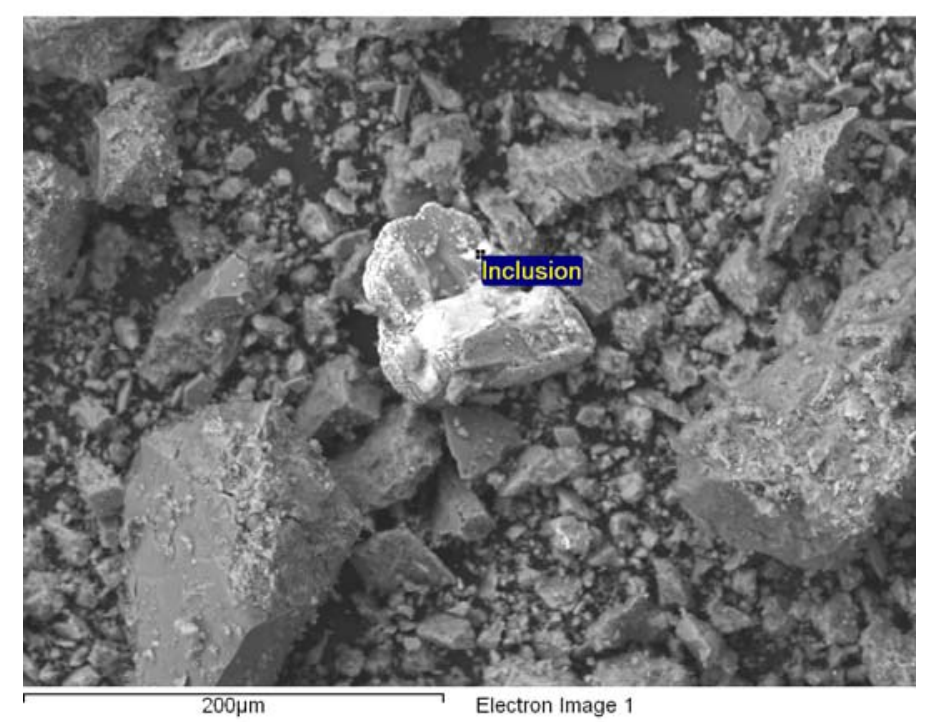

\begin{tabular}{l|llll}
\hline Element & $\begin{array}{l}\text { Intensity } \\
\text { Corrn. }\end{array}$ & Weight $\%$ & $\begin{array}{l}\text { Weight } \% \\
\text { Sigma }\end{array}$ & Atomic\% \\
$\mathrm{O} \mathrm{K}$ & 0.6479 & 47.56 & 0.23 & 70.15 \\
$\mathrm{Na} \mathrm{K}$ & 0.6448 & 0.92 & 0.09 & 0.95 \\
$\mathrm{Mg} \mathrm{K}$ & 0.6206 & 0.97 & 0.04 & 0.95 \\
$\mathrm{Al} \mathrm{K}$ & 0.7374 & 6.65 & 0.06 & 5.82 \\
$\mathrm{Si} \mathrm{K}$ & 0.7805 & 17.84 & 0.10 & 14.99 \\
$\mathrm{~K} \mathrm{~K}$ & 0.9478 & 0.41 & 0.04 & 0.25 \\
$\mathrm{Ca} \mathrm{K}$ & 0.9281 & 3.03 & 0.04 & 1.79 \\
$\mathrm{Ti} \mathrm{K}$ & 0.8040 & 0.08 & 0.03 & 0.04 \\
$\mathrm{Fe} \mathrm{K}$ & 0.8582 & 6.90 & 0.07 & 2.91 \\
$\mathrm{Cu} \mathrm{K}$ & 0.8325 & 0.61 & 0.06 & 0.23 \\
$\mathrm{Zn} \mathrm{K}$ & 0.8354 & 0.36 & 0.06 & 0.13 \\
$\mathrm{Sn} \mathrm{L}$ & 0.7351 & 1.70 & 0.11 & 0.34 \\
$\mathrm{~Pb} \mathrm{M}$ & 0.7450 & 12.96 & 0.13 & 1.48 \\
Totals & & 100.00 & & \\
\hline
\end{tabular}

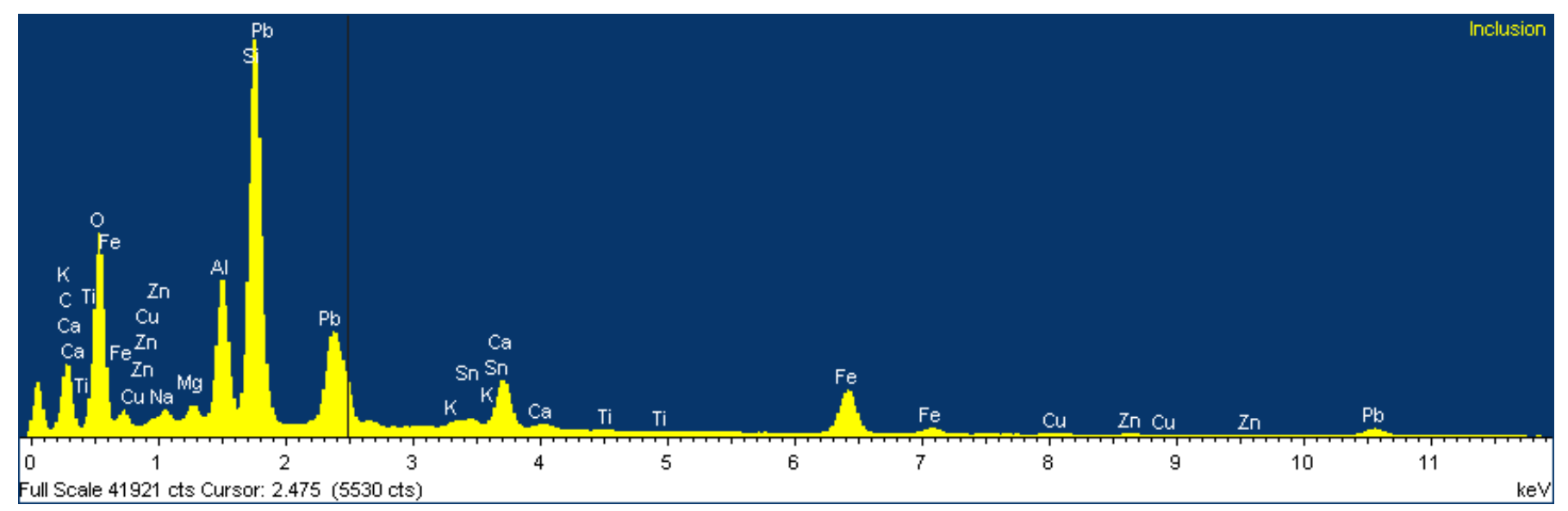

Figure E.6. 30-Day Cured Geopolymer Batch \#1 


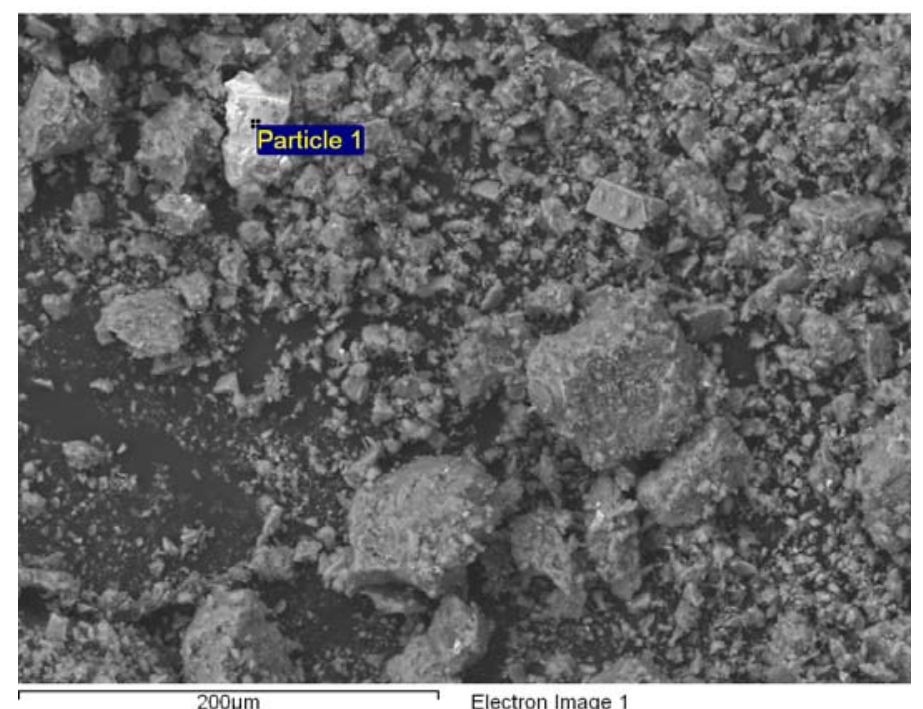

\begin{tabular}{l|llll}
\hline Element & Intensity & Weight $\%$ & $\begin{array}{l}\text { Weight\% } \\
\text { Sigma }\end{array}$ & Atomic\% \\
& Corrn. & & \\
O K & 0.3449 & 13.13 & 0.43 & 36.40 \\
Na K & 0.8747 & 0.18 & 0.06 & 0.34 \\
Al K & 0.9439 & 0.70 & 0.06 & 1.15 \\
Si K & 1.0086 & 19.51 & 0.24 & 30.80 \\
K K & 0.8156 & 0.76 & 0.08 & 0.86 \\
Ca K & 0.8484 & 0.19 & 0.07 & 0.21 \\
Sr L & 0.9474 & 1.75 & 0.36 & 0.89 \\
Zr L & 0.7350 & 57.26 & 0.57 & 27.83 \\
Hf L & 0.7900 & 1.79 & 0.46 & 0.44 \\
Au M & 0.7743 & 4.73 & 0.47 & 1.07 \\
& & & & \\
Totals & & 100.00 & & \\
\hline
\end{tabular}

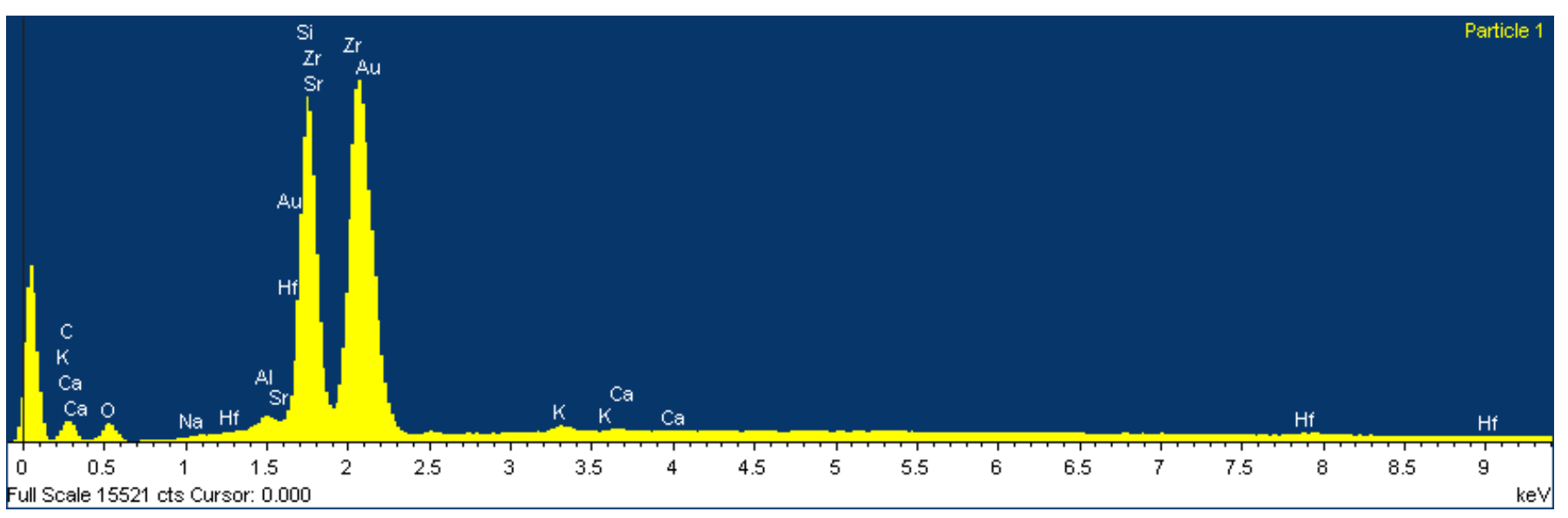

Figure E.7. 30-Day Cured Geopolymer Batch \#2 


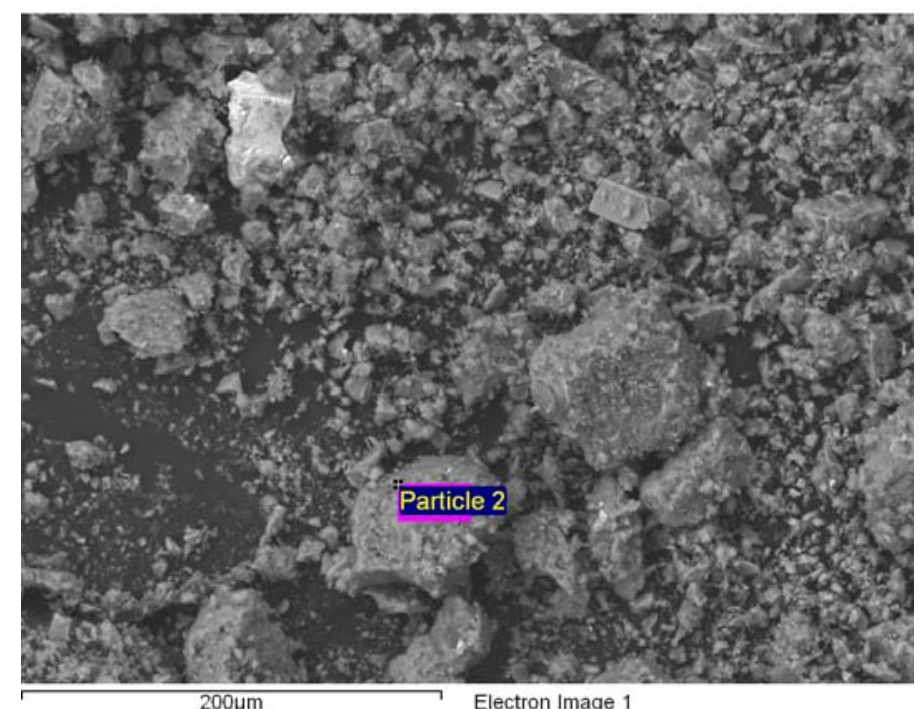

\begin{tabular}{l|llll}
\hline Element & $\begin{array}{l}\text { Intensity } \\
\text { Corrn. }\end{array}$ & Weight\% & $\begin{array}{l}\text { Weight\% } \\
\text { Sigma }\end{array}$ & Atomic\% \\
O K & 0.5740 & 50.80 & 0.36 & 65.92 \\
$\mathrm{Na} \mathrm{K}$ & 0.7466 & 1.38 & 0.07 & 1.25 \\
$\mathrm{Mg} \mathrm{K}$ & 0.7070 & 0.43 & 0.05 & 0.36 \\
$\mathrm{Al} \mathrm{K}$ & 0.8268 & 5.24 & 0.08 & 4.03 \\
$\mathrm{Si} \mathrm{K}$ & 0.8467 & 30.55 & 0.24 & 22.58 \\
$\mathrm{~K} \mathrm{~K}$ & 0.9727 & 6.27 & 0.09 & 3.33 \\
$\mathrm{Ca} \mathrm{K}$ & 0.9107 & 4.12 & 0.08 & 2.13 \\
Ti K & 0.7821 & 0.30 & 0.05 & 0.13 \\
Fe K & 0.8192 & 0.41 & 0.07 & 0.15 \\
Mo L & 0.6338 & 0.50 & 0.11 & 0.11 \\
& & & & \\
Totals & & 100.00 & & \\
\hline
\end{tabular}

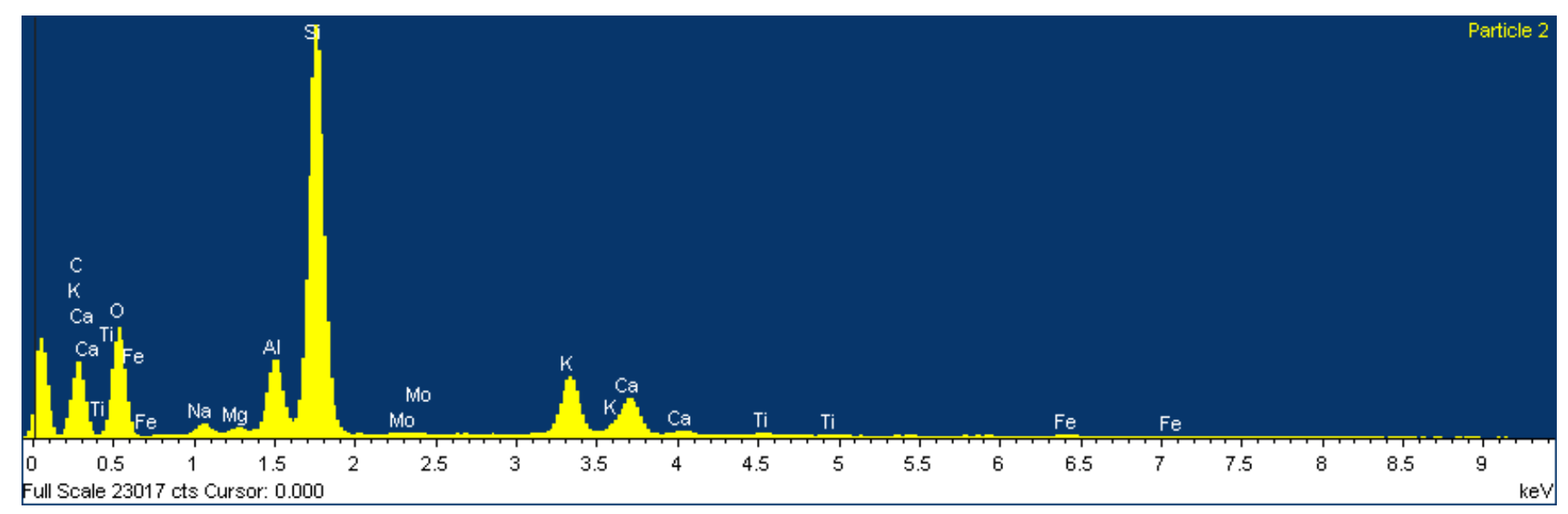

Figure E.8. 30-Day Cured Geopolymer Batch \#2 


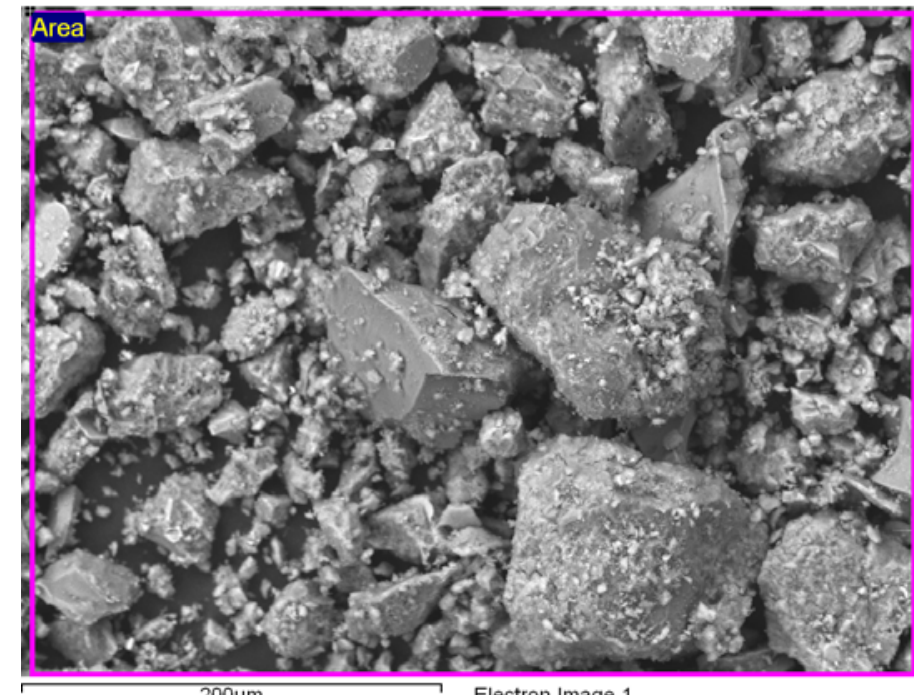

\begin{tabular}{l|llll}
\hline Element & $\begin{array}{l}\text { Intensity } \\
\text { Corrn. }\end{array}$ & Weight $\%$ & $\begin{array}{l}\text { Weight } \% \\
\text { Sigma }\end{array}$ & Atomic\% \\
O K & 0.5765 & 52.58 & 0.25 & 67.95 \\
$\mathrm{Na} \mathrm{K}$ & 0.7196 & 1.46 & 0.05 & 1.31 \\
$\mathrm{Mg} \mathrm{K}$ & 0.6843 & 0.83 & 0.03 & 0.70 \\
$\mathrm{Al} \mathrm{K}$ & 0.7990 & 6.72 & 0.06 & 5.15 \\
$\mathrm{Si} \mathrm{K}$ & 0.8103 & 24.70 & 0.14 & 18.18 \\
$\mathrm{~S} \mathrm{~K}$ & 0.7443 & 0.15 & 0.02 & 0.09 \\
$\mathrm{~K} \mathrm{~K}$ & 0.9910 & 7.36 & 0.07 & 3.89 \\
$\mathrm{Ca} \mathrm{K}$ & 0.9178 & 4.36 & 0.06 & 2.25 \\
$\mathrm{Ti} \mathrm{K}$ & 0.7807 & 0.38 & 0.03 & 0.17 \\
Fe K & 0.8190 & 0.25 & 0.04 & 0.09 \\
Sn L & 0.7590 & 0.62 & 0.15 & 0.11 \\
Sb L & 0.7603 & 0.58 & 0.13 & 0.10 \\
Totals & & 100.00 & & \\
\hline
\end{tabular}

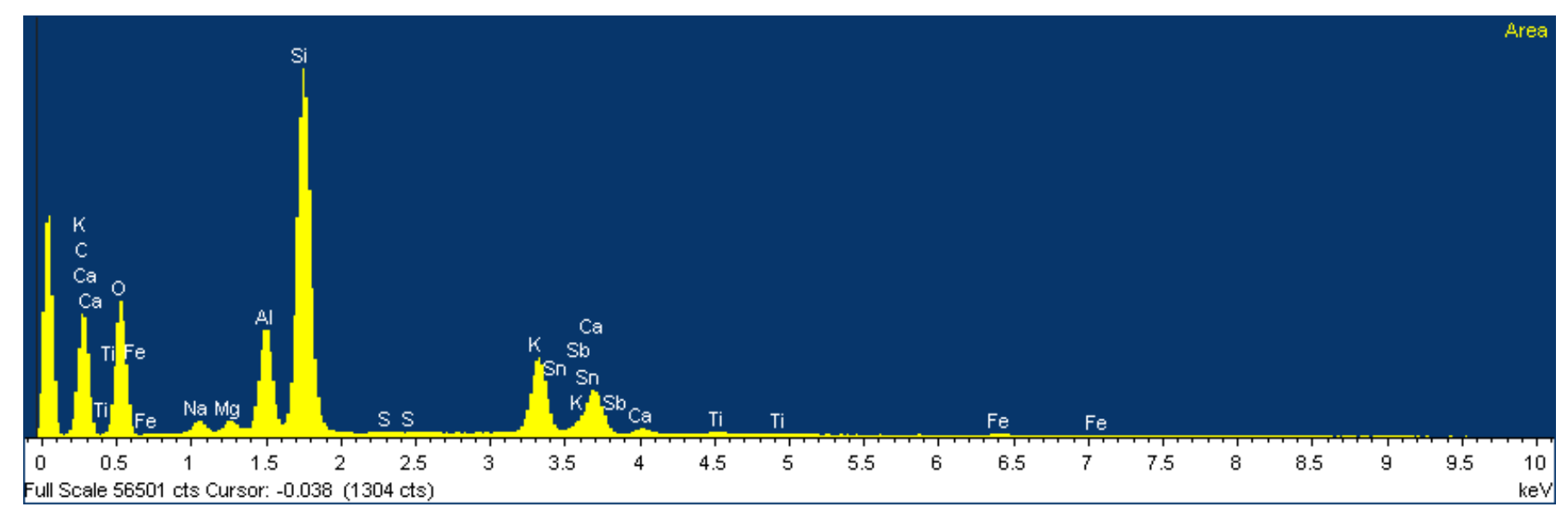

Figure E.9. Reacted Geopolymer Batch $\# 2$ using EPA Method $1313, \mathrm{pH}\left(23^{\circ} \mathrm{C}\right)=12$ 


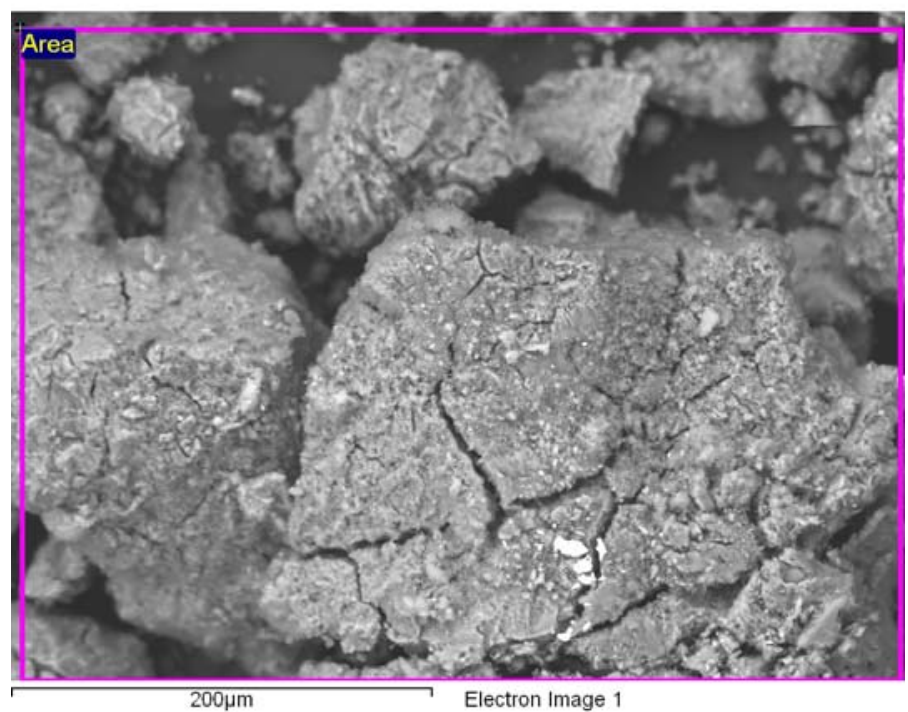

\begin{tabular}{l|llll}
\hline Element & $\begin{array}{l}\text { Intensity } \\
\text { Corrn. }\end{array}$ & Weight\% & $\begin{array}{l}\text { Weight\% } \\
\text { Sigma }\end{array}$ & Atomic\% \\
& & & \\
O K & 0.8788 & 34.60 & 0.92 & 55.35 \\
$\mathrm{Na} \mathrm{K}$ & 0.5697 & 0.35 & 0.04 & 0.39 \\
$\mathrm{Mg} \mathrm{K}$ & 0.5749 & 0.59 & 0.03 & 0.62 \\
$\mathrm{Al} \mathrm{K}$ & 0.7028 & 8.99 & 0.24 & 8.52 \\
$\mathrm{Si} \mathrm{K}$ & 0.7281 & 17.60 & 0.46 & 16.04 \\
$\mathrm{~K} \mathrm{~K}$ & 1.0323 & 2.55 & 0.07 & 1.67 \\
$\mathrm{Ca} \mathrm{K}$ & 0.9895 & 0.95 & 0.03 & 0.61 \\
$\mathrm{Ti} \mathrm{K}$ & 0.8515 & 0.28 & 0.02 & 0.15 \\
$\mathrm{Cr} \mathrm{L}$ & 0.2183 & 33.29 & 1.75 & 16.39 \\
$\mathrm{Fe} \mathrm{K}$ & 0.8173 & 0.34 & 0.02 & 0.15 \\
$\mathrm{Cu} \mathrm{K}$ & 0.8177 & 0.09 & 0.03 & 0.03 \\
$\mathrm{Sb} \mathrm{L}$ & 0.7969 & 0.20 & 0.05 & 0.04 \\
$\mathrm{Hg} \mathrm{M}$ & 0.7278 & 0.18 & 0.04 & 0.02 \\
Totals & & 100.00 & & \\
\hline
\end{tabular}

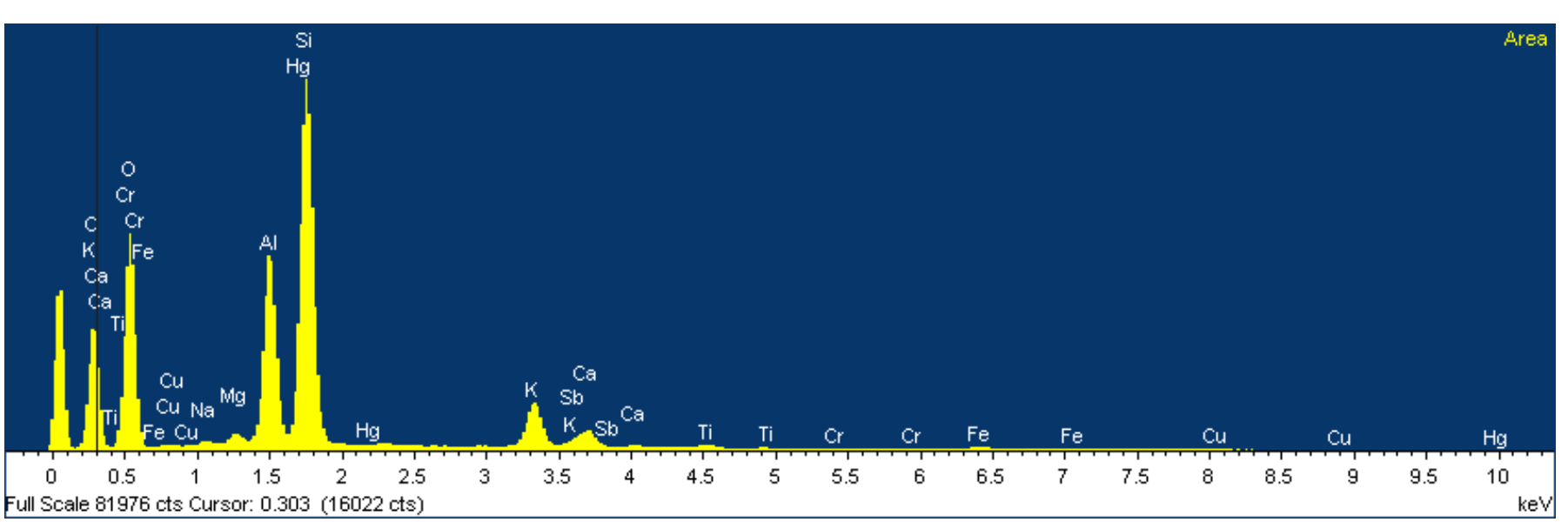

Figure E.10. Reacted Geopolymer Batch $\# 2$ using EPA Method $1313, \mathrm{pH}\left(23^{\circ} \mathrm{C}\right)=4$ 


\section{Appendix F}

\section{Eh-pH Diagrams for Specific Contaminants of Concern}




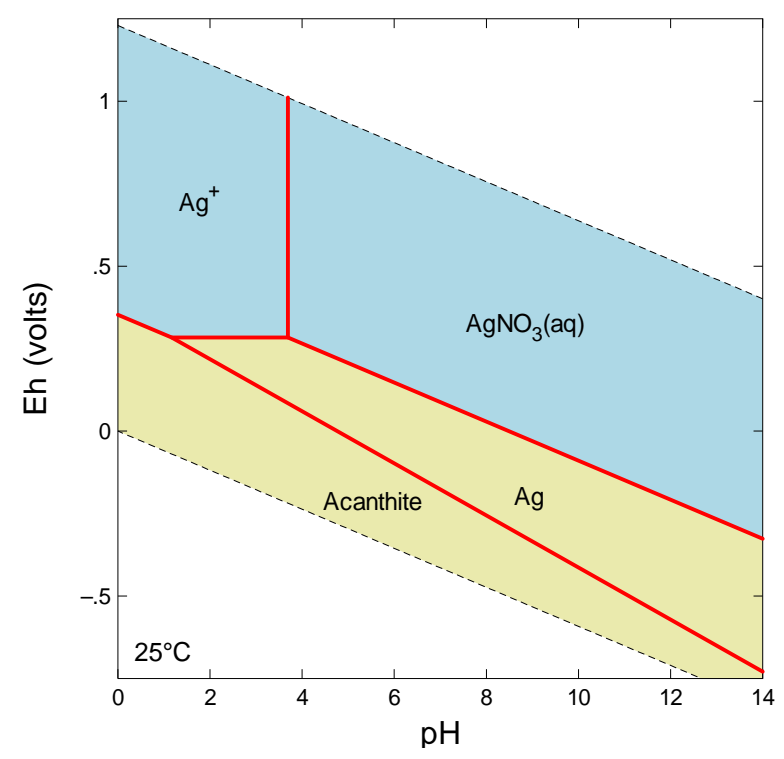

Figure F.1. Eh-pH Stability Diagram for Dominant Silver Species at $25^{\circ} \mathrm{C}$ for the Cast Stone Leachants Collected at 14 Days. The Diagram was Developed Based on the Concentrations of the Various Constituents Measured in the Cast Stone Waste Form Leachates at Day 14. More Details for the Concentrations can be found in Table 5.13-15.

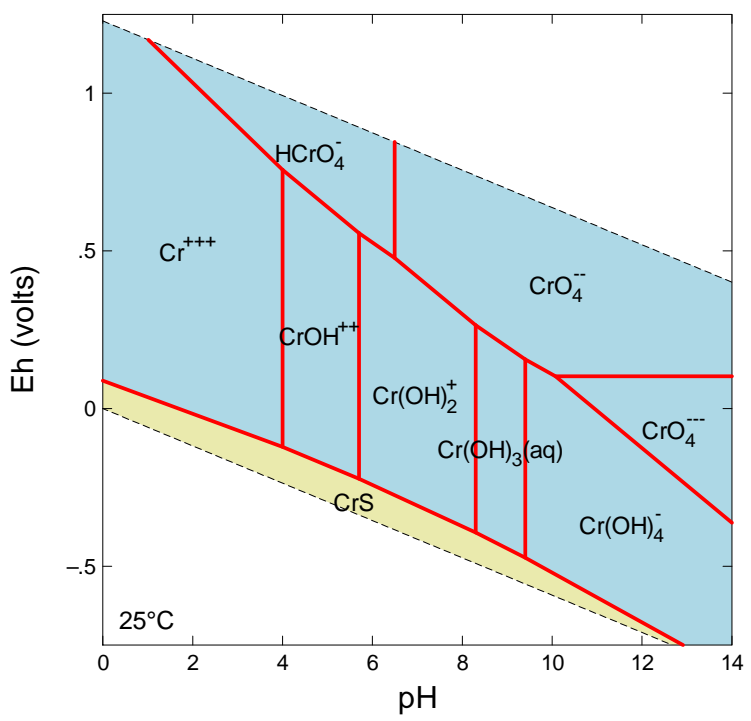

Figure F.2. Eh-pH Stability Diagram for Dominant Chromium Species at $25^{\circ} \mathrm{C}$ for the Cast Stone Leachants Collected at 14 Days. The Diagram was Developed Based on the Concentrations of the Various Constituents Measured in the Cast Stone Waste Form Leachates at Day 14. More Details for the Concentrations can be found in Table 5.13-15. 


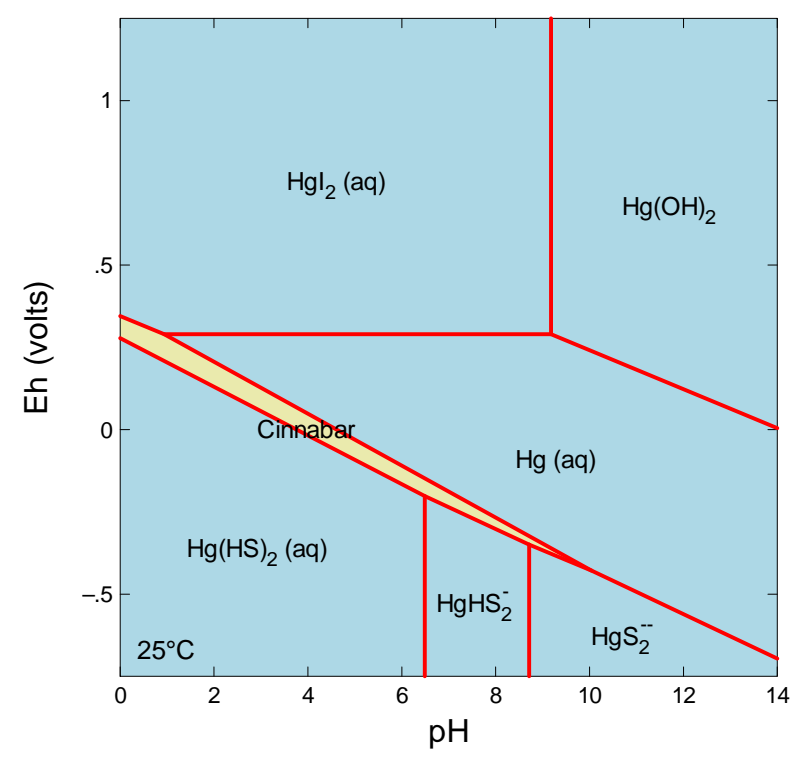

Figure F.3. Eh-pH Stability Diagram for Dominant Mercury Species at $25^{\circ} \mathrm{C}$ for the Cast Stone Leachants Collected at 14 Days. The Diagram was Developed Based on the Concentrations of the Various Constituents Measured in the Cast Stone Waste Form Leachates at Day 14. More Details for the Concentrations can be found in Table 5.13-15.

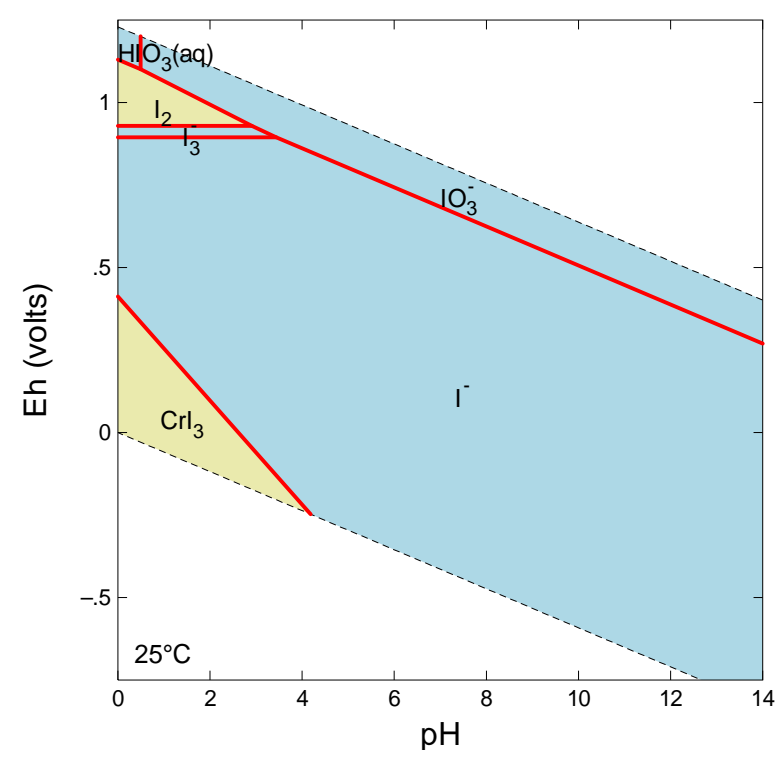

Figure F.4. Eh-pH Stability Diagram for Dominant Iodide Species at $25^{\circ} \mathrm{C}$ for the Cast Stone Leachants Collected at 14 Days. The Diagram was Developed Based on the Concentrations of the Various Constituents Measured in the Cast Stone Waste Form Leachates at Day 14. More Details for the Concentrations can be found in Table 5.13-15. 


\section{Distribution}

No. of

$\underline{\text { Copies }}$

\section{Off site}

2 Vitreous State Laboratory

The Catholic University of America

Hannan Hall Room 402

620 Michigan Avenue NE

Washington, D.C. 20064

W. Lutze

W. Gong

3 Civil \& Environmental Engineering

2301 Vanderbilt Place

Nashville, TN. 37235-1831

D. Kosson

K.G. Brown

A.C. Garrabrants

3 Savannah River National Laboratory

P.O. Box 616

Aiken, SC 29802

Attn: D. Kaplan

G. Flach

C. Langton

C. Jantzen
No. of

\section{Copies}

\section{Foreign Distribution}

Hans vander Sloot

vander Sloot consultancy

Dorpsstraat 216

1721 BV Langedijk

The Netherlands

$25 \quad$ Local Distribution

US Department of Energy

B.M. Mauss

H6-60

J. Morse

A5-11

R.D. Hildebrand

A6-38

R.W. Lober

H6-60

DOE Public Reading Room (2)

CH2MHill Plateau Remediation

Company

L. Lehman

H8-51

M. Wood

$\mathrm{H} 8-51$

Washington River Protection Solutions

K. Colosi B1-55

T. May

B1 -55

M. Melvin

B1-55

Pacific Northwest National Laboratory

$\begin{array}{ll}\text { E.M. Pierce } & \text { K3-62 } \\ \text { W. Um } & \text { K6-81 } \\ \text { S.V. Mattigod } & \text { K3-62 } \\ \text { R.J. Serne } & \text { K6-81 } \\ \text { N. Qafoku } & \text { K8-96 } \\ \text { K. Cantrell } & \text { K6-81 } \\ \text { L. Peurrung } & \text { K9-09 } \\ \text { P. Bredt } & \text { K9-09 } \\ \text { M. Triplett } & \text { K6-52 } \\ \text { J. Westsik (5) } & \text { K7-15 }\end{array}$





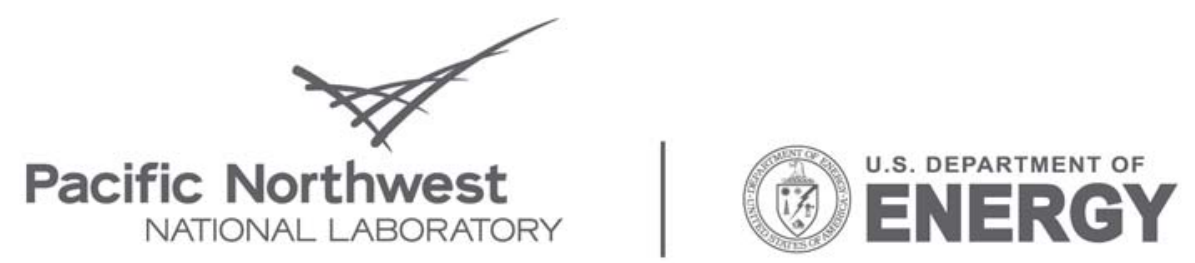

Proudly Operated by Battelle Since 1965

902 Battelle Boulevard

P.O. Box 999

Richland, WA 99352

1-888-375-PNNL (7665)

www.pnl.gov 